\title{
Hvorfor vokser steder?
}

Knut Vareide

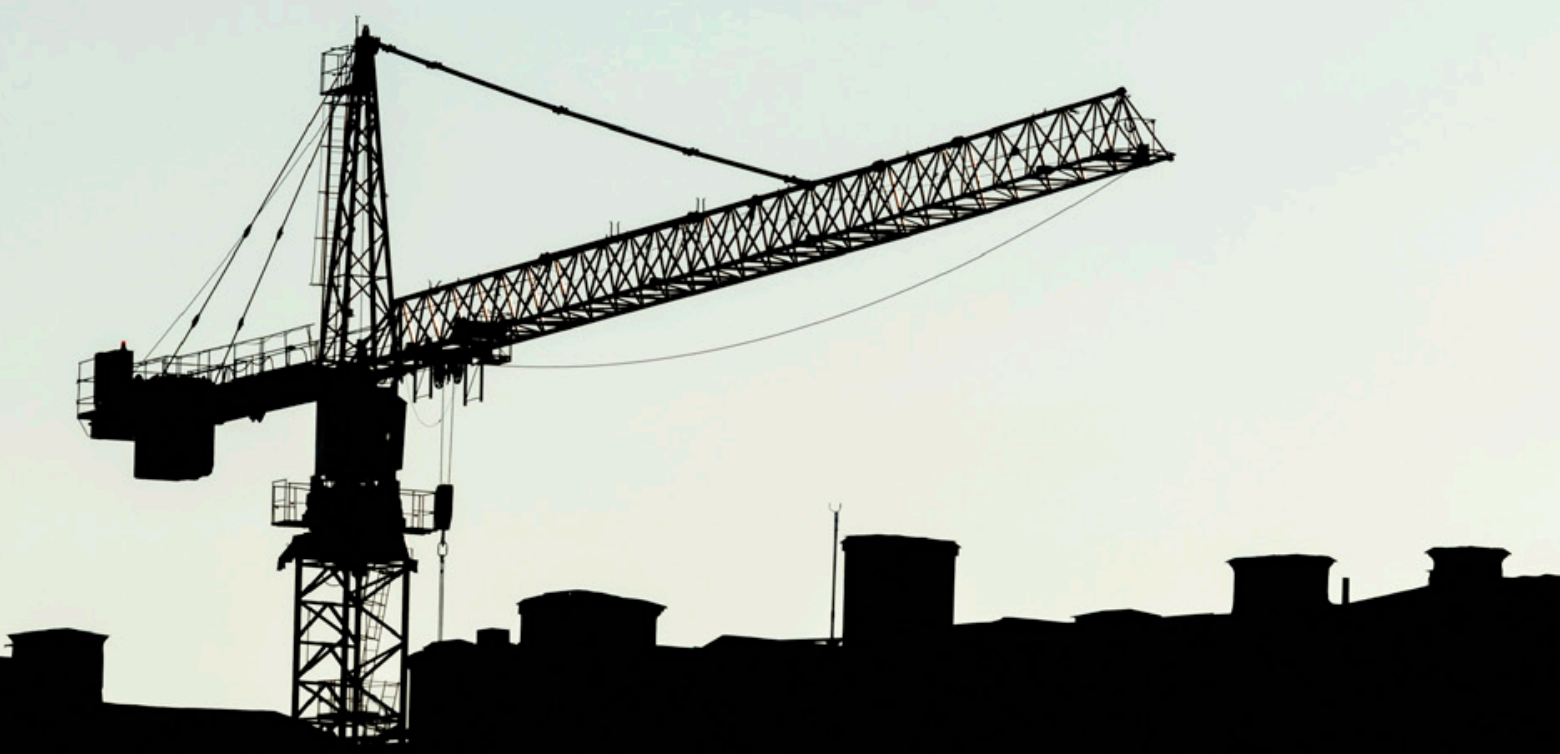


Hvorfor vokser steder? 

Knut Vareide

\section{Hvorfor vokser steder?}

OG HVORDAN KAN UTVIKLINGEN PÅVIRKES? 
(c) Knut Vareide, 2018.

Dette verket omfattes av bestemmelsene i Lov om opphavsretten til åndsverk m.v. av 1961. Verket utgis Open Access under betingelsene i Creative Commons-lisensen CC-BY 4.0 (http://creativecommons.org/licenses/by/4.o/), med unntak av forsideillustrasjonen. Denne tillater tredjepart å kopiere, distribuere og spre verket i hvilket som helst medium eller format, og å remixe, endre, og bygge videre på materialet til et hvilket som helst formål, inkludert kommersielle, under betingelse av at korrekt kreditering og en lenke til lisensen er oppgitt, og at man indikerer om endringer er blitt gjort. Tredjepart kan gjøre dette på enhver rimelig måte, men uten at det kan forstås slik at lisensgiver bifaller tredjepart eller tredjeparts bruk av verket.

Boka er utgitt med støtte fra Telemarksforsking.

ISBN: 978-82-02-54989-3 PDF

Typesetting: Datapage India (Pvt.) Ltd.

Cover Design: Cappelen Damm

Omslagsfoto: Albin Hillert / Shutterstock Bildet er brukt med tillatelse fra Shutterstock. Forsideillustrasjonen er ikke omfattet av CC-BY 4.o-lisens, og kan ikke gjenbrukes uten tillatelse fra Shutterstock.

Cappelen Damm Akademisk/NOASP

noasp@cappelendamm.no 


\section{Forord}

I denne boka har vi oppsummert resultatene av mange års forskning $\mathrm{i}$ Telemarksforsking. De siste tre årene har denne forskningen skjedd i regi av prosjektet «Attraksjonskraft gjennom stedsinnovasjon». Dette prosjektet var et oppdrag fra Telemark, Vestfold, Buskerud og Østfold fylkeskommuner og ble finansiert av Oslofjordfondet.

Prosjektet «Programteori for attraktivitet», et prosjekt der det daværende Kommunal- og regionaldepartementet var oppdragsgiver, og som ble avsluttet våren 2013, var utgangspunktet vårt. «Programteori for attraktivitet» bygget igjen på forskning på attraktivitet i regi av VRI-programmet. Telemarksforsking har vært heldige som har kunnet arbeide uavbrutt med forskning på stedlig attraktivitet gjennom en serie av prosjekter i nesten ti år.

Dette arbeidet tok til i 2007, da vi først begynte å bruke attraktivitetsbegrepet. Da var attraktivitetsbegrepet knyttet til at noen steder hadde systematisk høyere nettoflytting enn arbeidsplassveksten skulle tilsi. Attraktivitetsbegrepet ble da bare brukt i betydningen bostedsattraktivitet. Senere utvidet vi attraktivitetsbegrepet til tre B-er: bosted, besøk og bedrift, i en modell vi kalte for Attraktivitetspyramiden. I forbindelse med «Programteori for attraktivitet» begynte vi å skille mellom såkalte strukturelle forhold og «ekte attraktivitet». Strukturelle forhold er et samlebegrep på forhold som påvirker utviklingen på et sted, men som ikke kan påvirkes av stedet selv i særlig grad. Det er forhold som ofte har med lokalisering å gjøre, som at stedet ligger nær en større by som det deler arbeidsmarkedet med, økonomiske konjunkturer som påvirker den generelle veksten, og hvordan veksten varierer mellom ulike bransjer og sektorer. Attraktivitet ble da et begrep for å beskrive utviklingen på et sted utover det som kunne forklares av strukturelle faktorer. Idéen er at det som ikke kan forklares av strukturelle eller «ytre» faktorer, er et uttrykk for stedets egen attraktivitet, og at denne attraktiviteten kan påvirkes lokalt. De strukturelle 
forholdene vil bestemme hva som er en normal (i betydningen statistisk forventet) utvikling på stedet. Stedets attraktivitet vil da være de forholdene på stedet som fører til at utviklingen blir annerledes enn denne forventede utviklingen. På noen steder vil det være en overraskende sterk vekst. Slike steder vil da ha en positiv attraktivitet.

En ganske vesentlig del av forskningen på attraktivitet har vært å utarbeide en rekke regionale analyser, der vi har tatt utgangspunkt i den til enhver tid siste versjonen av attraktivitetsmodellen. Dette arbeidet har vært helt uvurderlig for å sikre relevans og kvalitet i modellen. De som arbeider med regional utvikling i praksis ute i kommuner, regioner og fylker, har mye kunnskap om stedlig utvikling generelt og sitt eget steds utvikling spesielt. Gjennom å anvende den teoretiske modellen på konkrete områder får vi direkte tilbakemeldinger både om hvor relevant modellen er, og om resultatene er troverdige.

Steder i denne sammenhengen kan være kommuner, regioner eller fylker. Poenget er at det er et avgrenset geografisk område innenfor et lands nasjonale grenser. Det finnes mye økonomisk teori for hvorfor vekst varierer mellom ulike land, men vårt arbeid er konsentrert om å avdekke drivkreftene til steders utvikling i forhold til andre steder i samme land. Det empiriske arbeidet vi har gjort, konsentrerer seg mest om norske steder, men vi har også gjort tilsvarende analyse for svenske og danske kommuner, og noen mer sporadiske arbeider i Polen, Tyskland, Latvia og Litauen.

De spørsmålene som vi ønsker å besvare, er, i kortversjon:

1. Hvorfor vokser noen steder, mens andre steder krymper?

2. Hva er de viktigste strukturelle drivkreftene?

3. Hva er sannsynlig framtidig utvikling av stedet?

4. I hvilken grad, og hvordan, kan et sted påvirke egen utvikling?

I denne boka skal vi arbeide oss systematisk gjennom attraktivitetsmodellen trinn for trinn, før vi tar fram interessante caser fra kommuner som har lykkes i å bli attraktive. 


\section{Innhold}

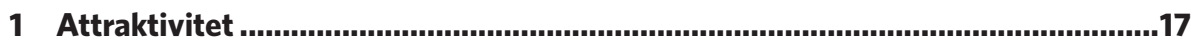

1.1 Om attraktivitetsmodellen i en kunnskapskontekst .................................................19

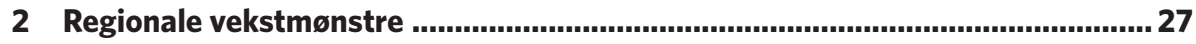

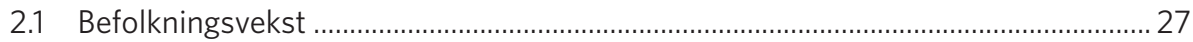

2.1.1 Mønstre i befolkningsvekst i regionene ................................................................2

2.1.2 Hvordan befolkningsendringer kan dekomponeres .........................................2

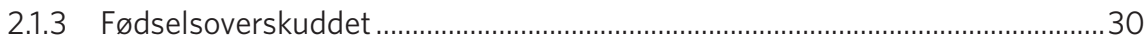

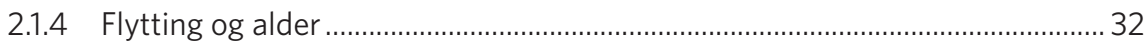

2.1.5 Flytting og kjønn ............................................................................................ 33

2.1.6 Innenlands nettoflytting ....................................................................................

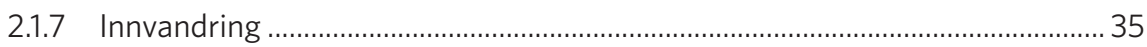

2.1.8 Innvandringsmønstre regioner ..............................................................................36

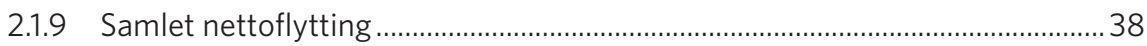

2.1.10 Relativ nettoflytting.................................................................................... 41

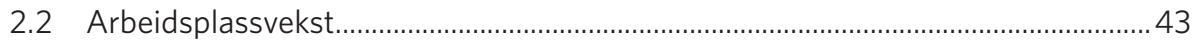

2.2.1 Vekst i næringslivet i ulike perioder .....................................................................4

2.2.2 Regionale variasjoner $\mathrm{i}$ arbeidsplassvekst..................................................... 45

2.3 Hva de regionale vekstmønstrene betyr for modellen .......................................... 47

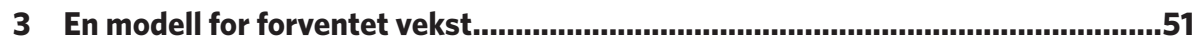

3.1 Drivkrefter for nettoflytting ………………………………………………....

3.1.1 Arbeidsplassvekstens effekt på flyttingen ...........................................................51

3.1.2 Sammenhengen mellom arbeidsplassvekst og nettoflytting ...........................52

3.1.3 Hvordan sammenhengen endres med ulike tidsperioder ...................................54

3.1.4 Hvordan sammenhengen endres med ulike geografiske inndelinger ..............56

3.1.5 Arbeidsplassvekst og pendling - egenvekst og nabovekst ...............................57

3.1.6 Rælingeneffekten: nettopendling .......................................................................58

3.1.7 Lørenskogeffekten: arbeidsmarkedsintegrasjon .............................................58

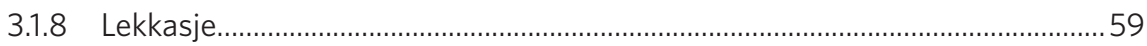

3.1.9 En modell for hvilken effekt arbeidsplassveksten har på flytting ..................... 61 
3.1.10 Sammenhengen mellom arbeidsplassvekst og nettoflytting over tid ........... 65

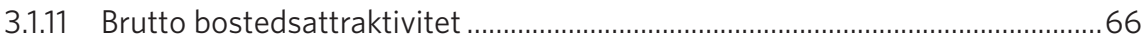

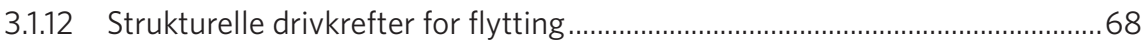

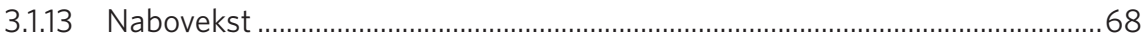

3.1.14 Kommuner med størst og minst effekt av nabovekst....................................... 70

3.1.15 Nettoflytting, egen arbeidsplassvekst og nabovekst .................................... 72

3.1.16 Strukturelle forhold - størrelse og arbeidsmarkedsintegrasjon ...................... 73

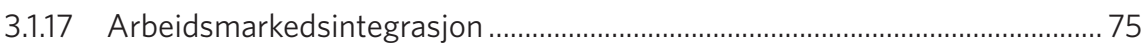

3.1.18 Arbeidsmarkedsintegrasjon og nettoflytting kommuner ................................ 77

3.1.19 Arbeidsmarkedsintegrasjon og nettoflytting regioner ..................................... 78

3.1.20 Intern arbeidsmarkedsintegrasjon regioner ........................................................ 78

3.1.21 Intern arbeidsmarkedsintegrasjon fylker ........................................................ 79

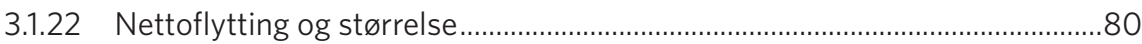

3.1.23 En modell for forventet nettoflytting ............................................................. 80

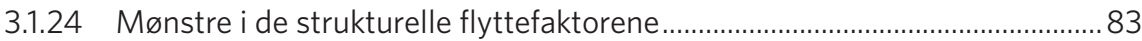

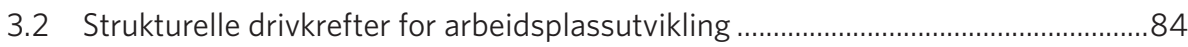

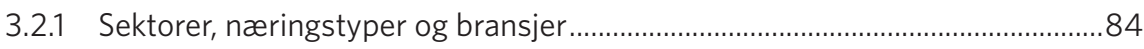

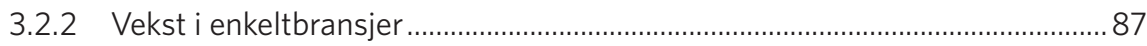

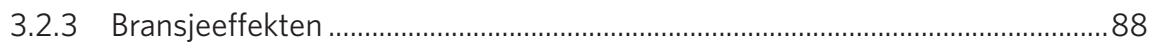

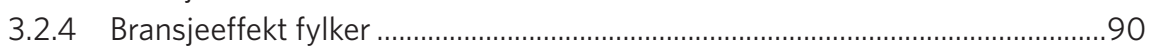

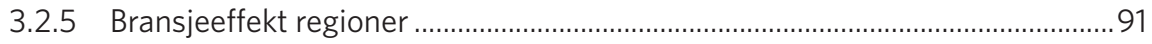

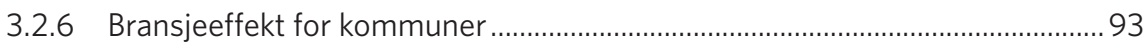

3.2.7 Mønstre bransjeeffekt ........................................................................................ 95

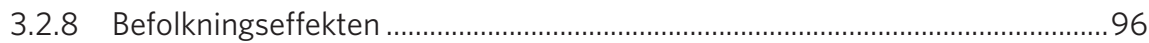

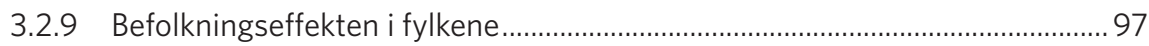

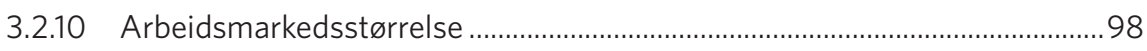

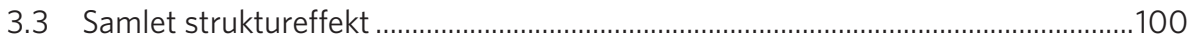

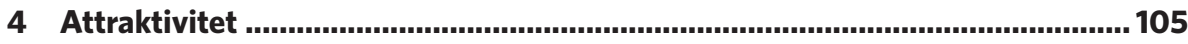

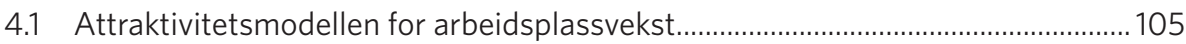

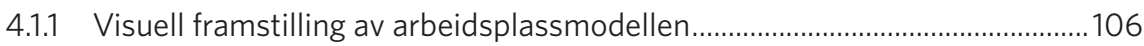

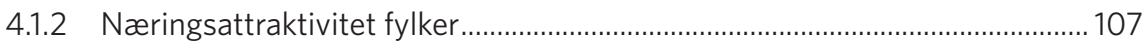

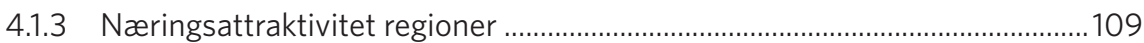

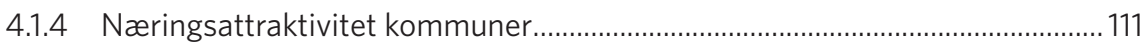

4.1.5 Næringsattraktivitet oppsplittet på næringstyper ............................................... 111

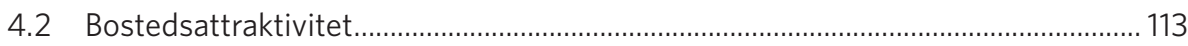

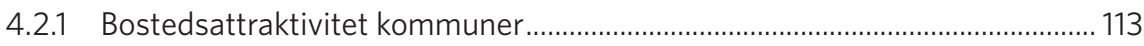

4.2.2 Bostedsattraktivitet i regioner ……................................................................... 1115

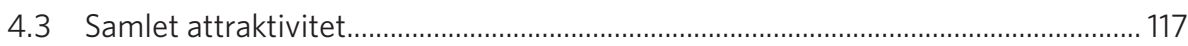

4.3.1 De mest attraktive kommunene i Norge ............................................................ 118

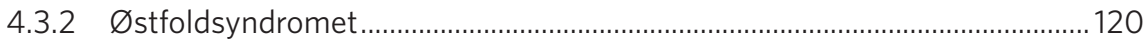

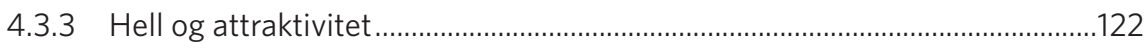




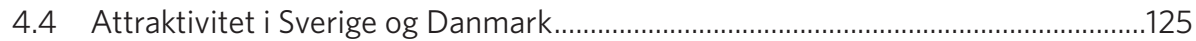

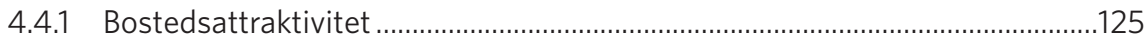

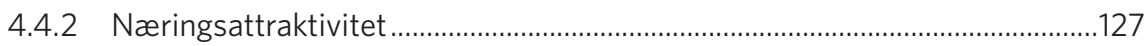

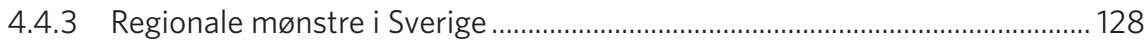

4.4.4 De mest attraktive bostedskommunene i Sverige...........................................132

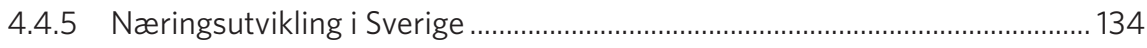

4.4.5.1 Kommunene som er mest attraktive for næringslivet............................135

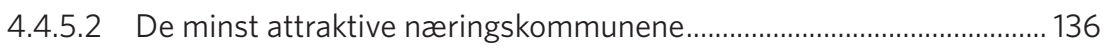

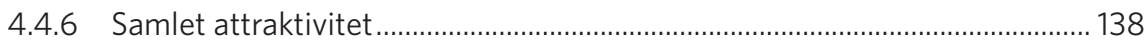

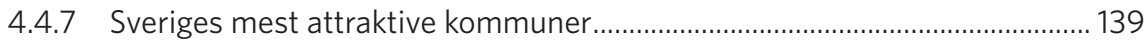

4.4.8 Regionale mønstre i Danmark ............................................................................. 140

4.4.8.1 De mest attraktive bostedskommunene i Danmark..............................144

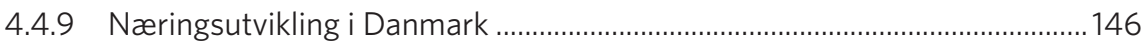

4.4.9.1 Mest attraktive kommuner for næringsliv........................................... 147

4.4.9.2 De minst attraktive næringskommunene.............................................. 148

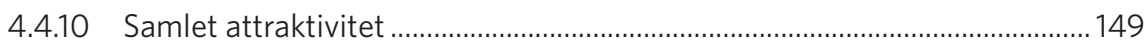

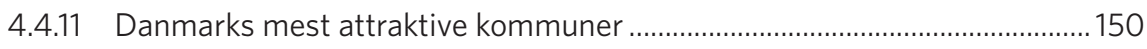

4.4.12 Mest attraktive kommune/region i Skandinavia? .............................................152

4.4.13 Høyest næringsattraktivitet i Skandinavia ...................................................... 154

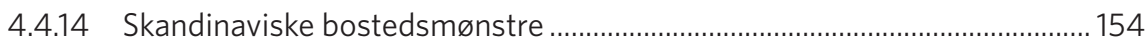

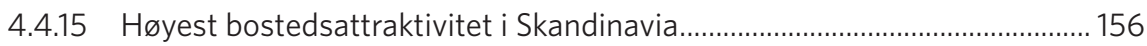

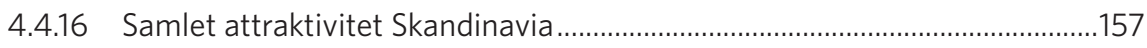

Scenariomodellen ..................................................................................................... 159

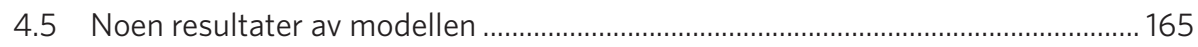

4.5.1 Hvor kommer arbeidsplassveksten? ................................................................ 166

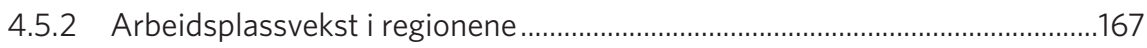

4.5.3 Oljekrisens betydning for fylkene................................................................... 168

4.5.4 Scenarioer med høy og lav attraktivitet ......................................................... 170

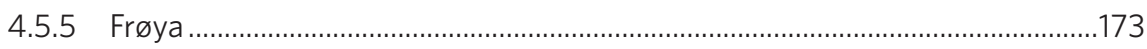

4.5.6 Kalibrering av mål i samfunnsplaner................................................................176

4.5.7 Attraktivitetsmodellen og SSBs middelframskriving...................................... 178

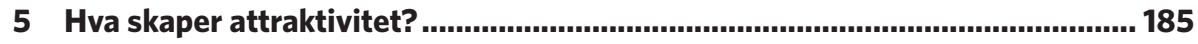

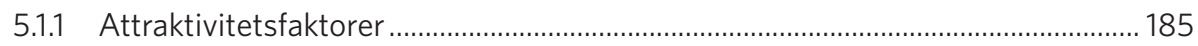

5.1.2 Kategorier av forhold som kan gjøre et sted attraktivt ........................................ 186

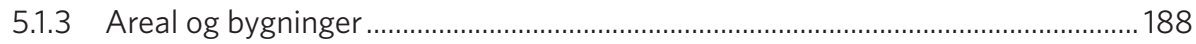

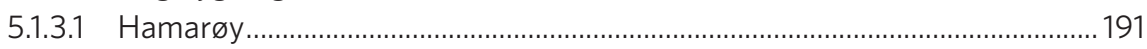

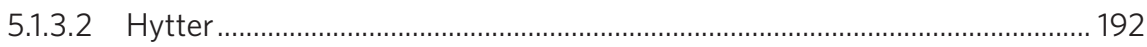

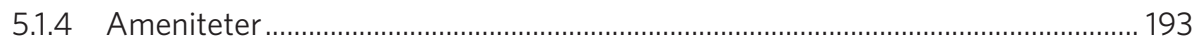

5.1.4.1 Kulturtilbud og bostedsattraktivitet ................................................................ 195 


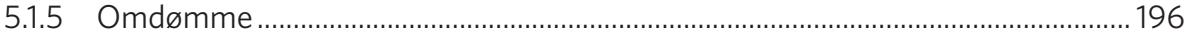

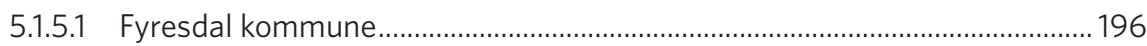

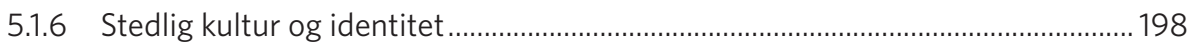

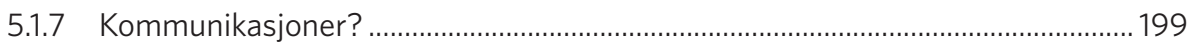

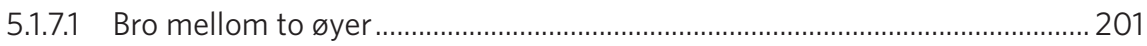

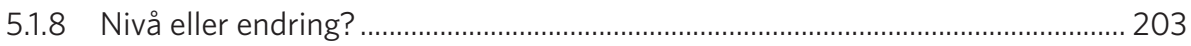

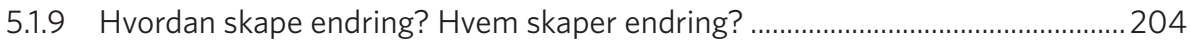

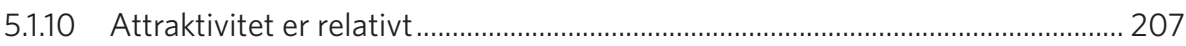

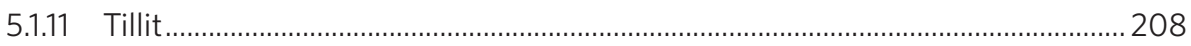

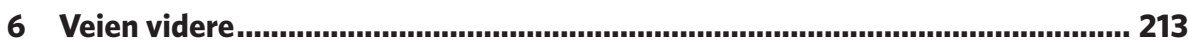

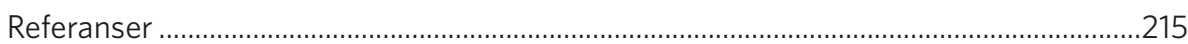

\section{Figures}

1.1 Prinsippskisse til attraktivitetsmodellen.......................................................................19

2.1 Årlige vekstrater i folketallet i kommunene i perioden 2000-2006 og 2007-2014, samt endringen i vekstrater mellom de to periodene............................28

2.2 Årlige vekstrater i folketallet i regionene i perioden 2000-2006 og 2007-2014, samt endringen i vekstrater mellom de to periodene............................29

2.3 Fødselsbalansens bidrag til årlig befolkningsvekst......................................................... 30

2.4 Prosentvis andel som flytter over kommunegrense i ulike alderstrinn..................... 33

2.5 Prosentvis andel som flytter over kommunegrense i ulike alderstrinn.

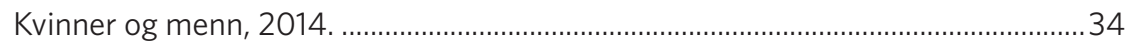

2.6 Den innenlandske nettoflyttingens bidrag til årlig befolkningsvekst...................... 35

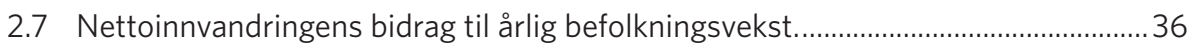

2.8 Nettoinnvandringens bidrag til årlig befolkningsvekst............................................ 37

2.9 Prosentvis bidrag til befolkningsveksten i Norge fra fødselsbalanse

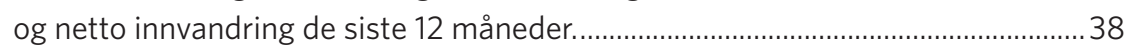

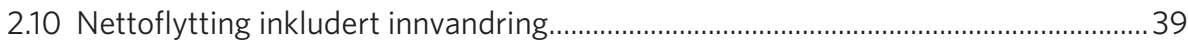

2.11 Samlet nettoflytting i kommunene, fordelt etter kvantiler, slik at det er like mange kommuner i hver gruppe. ............................................................................. 39

2.12 Samlet nettoflytting, fordelt etter kvantiler, slik at det er like mange

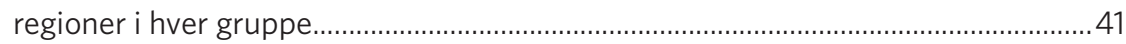

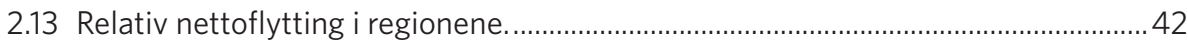

2.14 Utvikling i antall arbeidsplasser i Norge, indeksert slik at nivået i $2000=100 \ldots . . .43$

2.15 Prosentvis vekst i antall arbeidsplasser i næringslivet i årene 2000-2014,

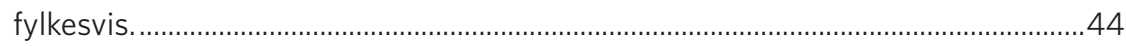

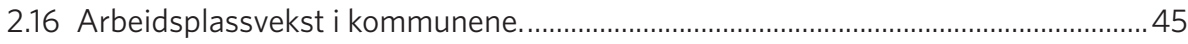

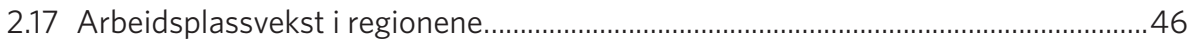

2.18 Logikk og struktur i attraktivitetsmodellen. ................................................................. 47

3.1 Kommunene i Norge, fordelt etter relativ arbeidsplassvekst og relativ

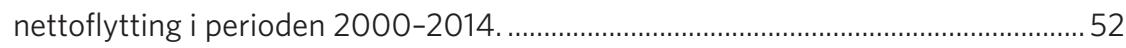

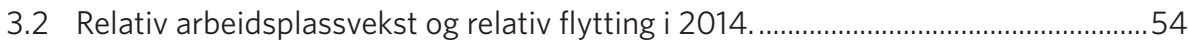


3.3 Relativ arbeidsplassvekst og relativ flytting i perioden 2012-2014 ….................... 55

3.4 Relativ arbeidsplassvekst og relativ flytting i perioden 2008-2014....................... 55

3.5 Relativ arbeidsplassvekst og relativ flytting i kommunene i perioden 2000-2014......56

3.6 Relativ arbeidsplassvekst og relativ flytting i fylkene, 2000-2014 ..........................56

3.7 Relativ arbeidsplassvekst og relativ flytting i regionene, 2000-2014 ..................... 57

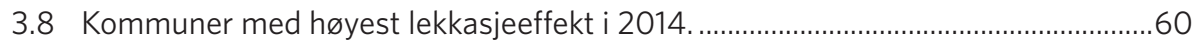

3.9 Kommuner med lavest lekkasjeeffekt i 2014............................................................60

3.10 Relativ nettoflytting i kommunene i 2014 og forventet nettoflytting basert

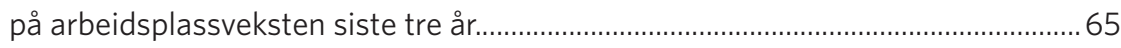

3.11 Relativ nettoflytting i kommunene i 2008-2014 og forventet nettoflytting basert på arbeidsplassveksten siste tre år.

3.12 Avvik mellom faktisk flytting og forventet flytting ut fra arbeidsplassvekst i eget område. Også kalt brutto bostedsattraktivitet.

3.13 Nettoflyttingens effekt på arbeidsplassveksten i nabokommuner i to perioder. Kartet viser naboveksten for kommunene.

3.14 Nettoflyttingens effekt på arbeidsplassveksten i nabokommuner i to perioder. Kartet viser naboveksten for regionene.

3.15 Effekten arbeidsplassvekst i nabokommuner har på nettoflytting (prosent av folketallet). Kommuner med høyest positiv effekt i perioden 2008-2014 ........71

3.16 Effekten arbeidsplassvekst i nabokommuner har på nettoflytting (prosent av folketallet). Kommuner med høyest negativ effekt i perioden 2008-2014.

3.17 Kommuner, fordelt etter faktisk nettoflytting og forventet nettoflytting ut fra arbeidsplassvekst i egen kommune og nabokommuner i 2014.

3.18 Regioner, fordelt etter faktisk nettoflytting og forventet nettoflytting ut fra arbeidsplassvekst i egen region og naboregioner i 2014.

3.19 Kommuner med høyest positivt avvik mellom faktisk nettoflytting og forventet nettoflytting ut fra arbeidsplassvekst i egen kommune og nabokommuner i perioden 2007-2014.

3.20 Kommuner med høyest negativt avvik mellom faktisk nettoflytting og forventet nettoflytting ut fra arbeidsplassvekst i egen kommune og nabokommuner i perioden 2007-2014.

3.21 Kommuner med høyest arbeidsmarkedsintegrasjon i 2014 ........................................ 76

3.22 Kommuner med lavest arbeidsmarkedsintegrasjon i 2014 ...................................... 76

3.23 Kommunene i Norge, etter nettoflytting i perioden 2007-2014 og arbeidsmarkedsintegrasjon.

3.24 Regionene i Norge, etter nettoflytting i perioden 2007-2014 og arbeidsmarkedsintegrasjon

3.25 Regionene i Norge, etter nettoflytting i perioden 2003-2015 og intern arbeidsmarkedsintegrasjon.

3.26 Fylkene i Norge, etter nettoflytting i perioden 2003-2015 og intern arbeidsmarkedsintegrasjon.

3.27 Sammenhengen mellom nettoflytting (2007-2014) og folketall (naturlig logaritme) 
3.28 Effekt på nettoflyttingen av henholdsvis nabovekst, befolkningsstørrelse og arbeidsmarkedsintegrasjon i perioden 2009-2014. Kartet lengst til høyre viser samlet effekt. Alle kartene er sortert etter kvantiler med like mange kommuner i hver gruppe.

3.29 Inndeling av næringslivet, utenom de lokale næringene. De røde/gule er bransjer i basisnæringer, de grønne besøksnæringer og de blå regionale næringer.

3.30 Indeksert arbeidsplassvekst i de ulike næringstypene og i offentlig sektor i Norge fra 2000 til 2014.

3.31 Prosentvis arbeidsplassvekst i de ulike bransjene i Norge i perioden 2000-2014......87

3.32 Bransjeeffekten (næringslivet) for fylkene i perioden 2009-2014. Effekten angir prosentvis avvik fra nasjonal vekst som følge av bransjestrukturen

3.33 Plott med bransjeeffekt og faktisk arbeidsplassvekst i næringslivet for perioden 2009-2014 forfylkene.

3.34 Bransjeeffekten for regioner med høyest bransjeeffekt i perioden 2009-2014. Effekten angir prosentvis avvik fra nasjonal vekst som følge av bransjestrukturen.....92

3.35 Bransjeeffekten for regioner med lavest bransjeeffekt i perioden 2009-2014. Effekten angir prosentvis avvik fra nasjonal vekst som følge av bransjestrukturen....93

3.36 Bransjeeffekten for kommuner med høyest bransjeeffekt i perioden 2009-2014. Effekten angir prosentvis avvik fra nasjonal vekst som følge av bransjestrukturen..... 94

3.37 Bransjeeffekten for kommuner med lavest bransjeeffekt i perioden 2009-2014. Effekten angir prosentvis avvik fra nasjonal vekst som følge av bransjestrukturen.... 94

3.38 Bransjeeffektens variasjoner på fylkesnivå, regionnivå og kommunenivå. Skalaen er «equal interval», som betyr at stedene er delt opp i fem grupper, som igjen er oppdelt i like intervaller fra minste til største nivå. Perioden 2009-2014.

3.39 Befolkningseffekt og bransjeeffekt i fylkene. Effekten er beregnet virkning på arbeidsplassveksten i næringslivet i perioden 2009-2014.

3.40 Struktureffekt, det vil si summen av bransjeeffekt og befolkningseffekt, og faktisk arbeidsplassvekst i fylkene i perioden 2009-2014.

3.41 Størrelse i antall arbeidsplasser og arbeidsplassvekst i 84 regioner i perioden 2009-2014

3.42 Sammenhengen mellom arbeidsmarkedsstørrelse og næringsattraktivitet. Næringsattraktivitet målt som avvik mellom forventet arbeidsplassvekst ut fra struktureffekt og faktisk arbeidsplassvekst.

3.43 Strukturelle drivkrefter for flytting og strukturelle drivkrefter for arbeidsplassvekst i næringsliv i perioden 2000-2015.

3.44 Strukturelle flyttefaktorer, strukturelle arbeidsplassfaktorer (for næringslivet) og samlet struktureffekt for kommunene i perioden 2002-2015.

4.1 Grafisk framstilling av modell for arbeidsplassvekst i næringslivet. 106

4.2 Forventet og faktisk arbeidsplassvekst i næringslivet i fylkene i perioden 2009-2014. 
4.3 Prosentvis arbeidsplassvekst, dekomponert i ulike strukturelle drivkrefter og attraktivitet i perioden 2009-2014.

4.4 Forventet og faktisk arbeidsplassvekst i næringslivet i regionene i perioden 2009-2014

4.5 Prosentvis arbeidsplassvekst, dekomponert i ulike strukturelle drivkrefter og attraktivitet i perioden 2009-2014.

4.6 Forventet og faktisk arbeidsplassvekst i næringslivet i kommunene i perioden 2009-2014

4.7 Prosentvis arbeidsplassvekst, dekomponert i ulike strukturelle drivkrefter og attraktivitet i perioden 2009-2014.

4.8 Næringsattraktivitet oppsplittet i tre næringstyper. Enheten er prosentvis andel av samlet sysselsetting

4.9 Næringsattraktivitet oppsplittet i tre næringstyper. Enheten er prosentvis andel av samlet sysselsetting.

4.10 Variasjoner mellom kommunene for nettoflytting, arbeidsplassvekst, brutto attraktivitet (avvik mellom faktisk nettoflytting og forventet nettoflytting ut fra arbeidsplassveksten), strukturelle flyttefaktorer og bostedsattraktivitet. Fordelingen av kommuner er i kvantiler med like mange kommuner i hver gruppe i alle kartene. Perioden 2009-2014

4.11 Variasjoner mellom regionene for nettoflytting, arbeidsplassvekst, brutto attraktivitet (avvik mellom faktisk nettoflytting og forventet nettoflytting ut fra arbeidsplassveksten), strukturelle flyttefaktorer og bostedsattraktivitet. Fordelingen av kommuner er i kvantiler med like mange kommuner i hver gruppe i alle kartene.

4.12 Attraktivitet for næringsliv og som bosted i norske kommuner i perioden 2006-2015.

4.13 De mest attraktive kommunene i Norge i perioden 2006-2015. 118

4.14 De minst attraktive kommunene i Norge i perioden 2006-2015. 119

4.15 Nærings- og bostedsattraktivitet i fylkene i perioden 2005-2015. Næringsattraktiviteten er skalert slik at den gjenspeiler effekten på nettoflyttingen.

4.16 Sysselsettingsandeler i Østfold og Rogaland (antall sysselsatte i prosent av antall personer i yrkesaktiv alder) i prosent av Norges sysselsettingsandel...

4.17 Vekstimpulser til befolkningen, knyttet til strukturelle forhold og til attraktivitet i perioden 2006-2015.

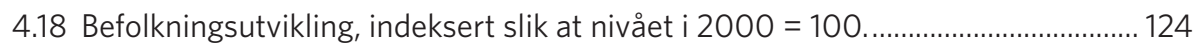

4.19 Befolkningsutvikling, indeksert slik at nivået i $2000=100$. .125

4.20 Faktisk og forventet relativ flytting i norske, svenske og danske kommuner i perioden 2011-2014.

4.21 Forventet og faktisk vekst i antall arbeidsplasser i næringslivet, prosent, i perioden 2011-2014 
4.22 Nettoflytting, arbeidsplasseffekt og brutto bostedsattraktivitet i svenske kommuner. Kommunene er delt inn i fem kvantiler, der mørkeblå er de høyeste verdiene og røde er de laveste. Hvite kommuner ligger i den midterste kvantilen....129

4.23 Beregnet effekt av kommunenes størrelse (innbyggertall), arbeidsmarkedsintegrasjon og arbeidsplassvekst i nabokommuner i svenske kommuner i perioden 2009-2014. I kartet til høyre er effekten av alle de tre strukturelle flyttefaktorene summert.

4.24 Variasjon i nettoflytting, effekten av arbeidsplassvekst i egen kommune, sum strukturelle flyttefaktorer og bostedsattraktivitet i svenske kommuner i perioden 2009-2014.

4.25 Kommunene med høyest bostedsattraktivitet i perioden 2009-2014.

4.26 Kommunene med lavest bostedsattraktivitet i perioden 2009-2014.

4.27 Bransjeeffekten, befolkningseffekten og samlet struktureffekt på arbeidsplassutviklingen i næringslivet i svenske kommuner i perioden 2009-2014.

4.28 Variasjoner i arbeidsplassvekst i næringslivet, strukturelle forhold for vekst og næringsattraktivitet i svenske kommuner i perioden 2009-2014

4.29 De mest attraktive næringskommunene i Sverige i perioden 2009-2014. Benevningen er prosent av samlet sysselsetting. 137

4.30 De minst attraktive næringskommunene i Sverige i perioden 2009-2014. Benevningen er prosent av samlet sysselsetting.

4.31 Samlet struktureffekt og samlet attraktivitet i svenske kommuner i perioden 2009-2014 138

4.32 De mest attraktive kommunene i Sverige i perioden 2009-2014. 139

4.33 De minst attraktive kommunene i Sverige i perioden 2009-2014. 140

4.34 Nettoflytting, arbeidsplasseffekt og brutto bostedsattraktivitet i danske kommuner. Kommunene er delt inn i fem kvantiler, der mørkeblå er de høyeste verdiene og de røde er de laveste. Hvite kommuner ligger i den midterste kvantilen. Bornholm er flyttet for å komprimere kartene.

4.35 Beregnet effekt av kommunenes størrelse (innbyggertall), arbeidsmarkedsintegrasjon og arbeidsplassvekst i nabokommuner i danske kommuner i perioden 2011-2014. I kartet nederst til høyre er effekten av alle de tre strukturelle flyttefaktorene summert.

4.36 Variasjon i nettoflytting, effekten av arbeidsplassvekst i egen kommune, sum strukturelle flyttefaktorer og bostedsattraktivitet i danske kommuner i perioden 2011-2014.

4.37 Kommunene med høyest bostedsattraktivitet i perioden $2011-2014$..................... 144

4.38 Kommunene med lavest bostedsattraktivitet i perioden 2011-2014. 145

4.39 Bransjeeffekten, befolkningseffekten og samlet struktureffekt på arbeidsplassutviklingen i næringslivet i danske kommuner i perioden 2011-2014.

4.40 Variasjoner i arbeidsplassvekst i næringslivet, strukturelle forhold for vekst og næringsattraktivitet i danske kommuner i perioden 2009-2014 
4.41 De mest attraktive næringskommunene i Danmark i perioden 2011-2014.

Benevningen er prosent av samlet sysselsetting.

4.42 De minst attraktive næringskommunene i Danmark i perioden 2011-2014.

Benevningen er prosent av samlet sysselsetting.....

4.43 Samlet struktureffekt og samlet attraktivitet i danske kommuner i perioden 2011-2014.

4.44 De mest attraktive kommunene i Danmark i perioden 2011-2014.

4.45 De minst attraktive kommunene i Danmark i perioden 2011-2014

4.46 Variasjon i arbeidsplassvekst i næringslivet, forventet arbeidsplassvekst og næringsattraktivitet (avvik mellom faktisk og forventet arbeidsplassvekst i næringslivet) i Norge, Sverige og Danmark i perioden 2009-2014.

4.47 Næringsattraktivitet i perioden 2009-2014, sammen med bidrag fra bransjeeffekt og nasjonal vekst. Enheten er prosentvis andel av samlet sysselsetting i kommunen/regionen. De 20 mest attraktive.

4.48 Næringsattraktivitet i perioden 2009-2014, sammen med bidrag fra bransjeeffekt og nasjonal vekst. Enheten er prosentvis andel av samlet sysselsetting i kommunen/regionen. De 20 minst attraktive.

4.49 Nettoflytting, forventet nettoflytting og bostedsattraktivitet i norske regioner og svenske og danske kommuner i perioden 2011-2014.

4.50 Bostedsattraktivitet i perioden 2011-2014, sammen med bidrag fra arbeidsplassvekst, struktur og nasjonal innvandring. Enheten er nettoflytting i prosent av folketallet.

4.51 Bostedsattraktivitet i perioden 2011-2014, sammen med bidrag fra arbeidsplassvekst, struktur og nasjonal innvandring. Enheten er nettoflytting i prosent av folketallet.

4.52 Samlet struktureffekt og samlet attraktivitet i perioden 2011-2014.

4.53 Skisse for attraktivitetsmodellen.

4.54 Arbeidsplassveksten i Norge fram til 2014, og beregnet arbeidsplassvekst fram til 2030. Oppdatert 2015.

4.55 Variasjoner i arbeidsplassveksten mellom regionene i perioden 2009-2014 og forventede variasjoner fram til 2030. Regionene er gruppert etter kvantiler.

4.56 Forventet arbeidsplassvekst i regionene. Til venstre: med trendframskriving av den strukturelle utviklingen (fortsatt vekst i oljerelaterte bransjer). I midten: med strukturell utvikling med nedgang i oljerelaterte bransjer. Til høyre: differansen mellom de to alternativene.

4.57 Attraktivitetsverdier for regioner i perioden 2000-2015, og attraktivitetsverdiene til høyvekst-, normal- og lavvekstscenarioet

4.58 Scenarioer for befolkningsvekst i Frøya.

4.59 Alle de fire scenarioene for folketallsutvikling i Frøya, samt MMMM sin er SSBs middelframskriving.

4.60 Scenarioer for befolkningsutvikling i Kongsberg samt MMMM sin er SSBs middelframskriving. 
4.61 Nettoflytting fram til 2015 som prosent av folketallet, og beregnet nettoflytting i SSBs framskrivinger.

4.62 Relativ nettoflytting fram til 2015 som prosent av folketallet, og beregnet relativ nettoflytting i SSBs framskrivinger.

4.63 Scenarioer for arbeidsplassvekst i Oslo, Hedmark og Norge, indeksert slik at nivået i $2015=100$.

4.64 Normalscenarioer og SSBs middelprognose for befolkning, for Oslo og Hedmark. Indeksert slik at nivået i $2016=100$.

4.65 Scenarioer for befolkningsutvikling i Hedmark.

5.1 Kommunene plassert etter boligpriser (gjennomsnittlig pris per m2 for eneboliger mellom 2009 og 2015) og boligbygging (gjennomsnittlig antall fullførte nye boliger per 1000 innbyggere i perioden 2009-2015).

5.2 Relativ nettoflytting i Hamarøy, dekomponert i arbeidsplasseffekt, strukturelle flyttefaktorer og bostedsattraktivitet.

5.3 Besøksattraktiviteten til de ti kommunene med høyest antall nye fritidsboliger per innbygger i perioden 2000-2015.

5.4 Analyse av nettoflytting til Fyresdal. Tre års glidende gjennomsnitt........................197

5.5 Analyse av relativ nettoflytting til Rennesøy (til venstre) og Finnøy (til høyre)..... 200

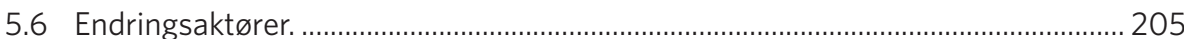

5.7 Ulike tillitsrelasjoner som er av betydning for å utvikle stedlig attraktivitet. ...... 209

\section{Tabeller}

2.1 Fruktbarhetstall i fylkene i ulike tiår, avvik fra landsgjennomsnittet. 31

3.1 Koeffisienter fra regresjonsanalyse av kommuner.

3.2 Koeffisienter fra regresjonsanalyse av regioner. 63

3.3 Resultater fra regresjonsanalysene med data fra årene 2000 til 2015. 82

3.4 Utregning av bransjeeffekten i Telemark for perioden 2009-2014. 89

4.1 Betaverdier fra regresjonsanalysene. 126

4.2 Årlige vekstrater i perioden 2000-2014 og hva som er forventede årlige vekstrater i perioden 2015-2030. Oppdatert 2015.

4.3 Årlige vekstrater i ulike bransjer og sektorer. 163

4.4 Antall arbeidsplasser i 2004 og 2014 samt beregnet antall arbeidsplasser i 2024, og samlet vekst siste ti år og beregnet vekst neste ti år.

4.5 Prosentvis vekst i antall arbeidsplasser fra 2014 til 2030 for to alternativer. Trend er en framskriving av bransjenes vekst de ti siste årene. Oljejustert er forventet vekst når olje- og gassrelaterte næringer får nedgang og andre næringer får økt vekst, slik at samlet arbeidsplassvekst blir lik i hele landet....... 169

4.6 Attraktivitetsverdier i høy- og lavvekstscenarioene for kommuner, regioner og fylker.

5.1 Kategorier av forhold som kan gjøre steder attraktive, og eksempler for tre ulike typer av attraktivitet.

5.2 Bostedsattraktivitet og boligbygging i forhold til pris i kommunene i Akershus samt Oslo i perioden 2009-2015 


\section{KAPITTEL 1}

\section{Attraktivitet}

Hvorfor har noen steder befolkningsvekst, mens andre steder har en krympende befolkning?

Det kan være mange forklaringer på at et sted vokser. Stedet kan være sentralt lokalisert i nærheten av en stor by, med gode muligheter for pendling. Stedet kan ligge i en større arbeidsmarkedsregion som har vekst i antall arbeidsplasser. Stedet har kanskje en ung befolkning, som gir et høyt fødselsoverskudd hvert år. Stedet har antakelig fått mange innvandrere som følge av at innvandringen til Norge har vært høy i en periode. Stedet kan også ha en sterk vekst i antall arbeidsplasser i eget næringsliv, som skaper innflytting fra andre steder. Dette er et sett med forklaringsfaktorer for hvorfor noen steder har en voksende befolkning. Med unntak av egen arbeidsplassutvikling er disse faktorene forhold som et sted ikke kan gjøre stort med. Vi kaller slike forhold «strukturelle forhold». De er forårsaket av stedets lokalisering, nasjonale sentraliseringskrefter, landets innvandring og befolkningens sammensetning på alder og kjønn. Steder som har vekst på grunn av slike forhold, kan sies å være heldig stilt for å oppnå befolkningsvekst. Det kreves ingen spesielle tiltak, endringer eller stedskvaliteter for at befolkningen skal vokse.

Bostedsattraktivitet er knyttet til forhold som har med stedets egne kvaliteter å gjøre - kvaliteter som stedet kan påvirke selv. Det er mange forhold som kan tenkes å gjøre et sted attraktivt som bosted: gode kommunale tjenester, gode skoler, et rikt kulturliv, trivelig gågate med et yrende folkeliv, trivelige fortauskafeer, mange fritidsaktiviteter, et godt omdømme, de beste boligtomtene, lave boligpriser, en åpen og gjestfri kultur, dugnadsånd og optimisme, bare for å nevne noen. Steder som skaper alle disse attraktivitetsfaktorene, vil kanskje kunne oppleve høy innflytting og befolkningsvekst, selv om de strukturelle forholdene ikke er gunstige. På samme måte vil steder som helt mangler slike attraktivitetsfaktorer, kanskje ikke få befolkningsvekst selv om de strukturelle forholdene ligger til rette for det. 
Vi skiller derfor mellom de strukturelle forholdene (som stedet ikke kan påvirke) og attraktivitet (som et sted kan påvirke). Den faktiske befolkningsveksten på et sted vil dermed bli summen av stedets strukturelle forutsetninger og stedets attraktivitet.

Det neste spørsmålet vi stiller oss, er: Hvorfor har noen steder vekst i antall arbeidsplasser, mens andre steder har fallende antall? Igjen er det mange mulige svar. Omtrent en tredel av arbeidsplassene i Norge er i offentlig sektor. I denne boka vil vi fokusere på næringsutviklingen, og da spesielt arbeidsplassutviklingen i privat sektor. Noen steder får vekst fordi de har en bransjesammensetning med mange bedrifter og arbeidsplasser i bransjer som har vekst. Andre steder får nedgang fordi næringslivet er konsentrert i bransjer som har nedgang, eller hvor det er en stadig rasjonalisering i antall arbeidsplasser. Noen deler av næringslivet blir også påvirket av befolkningsutviklingen på stedet. Det er spesielt bransjer som lokale tjenester og handel. Kanskje har det også betydning at det er en sterk konsentrasjon av næringsliv på stedet, eller at stedet er en del av et stort arbeidsmarked. Det finnes dermed også strukturelle forhold som kan forklare hvorfor næringslivet vokser med ulik takt på ulike steder.

Næringsattraktivitet er knyttet til lokale forhold som stedet selv kan påvirke. Kanskje har kommunen en spesielt næringsvennlig politikk? Kanskje er det et godt utvalg av næringstomter og næringslokaler? Bedriftene samarbeider godt, en hjørnesteinsbedrift har ekspandert kraftig, det er mange gründere i kommunen, eller det er nye attraksjoner på stedet som trekker til seg besøkende og skaper vekst i besøksnæringene?

Vi ønsker å finne ut hvorfor noen steder vokser, og begynner med de to fundamentale størrelsene: befolkning og arbeidsplasser. Dernest splitter vi settet med årsaksforhold i to: strukturelle forhold og attraktivitet. Det er også opplagt at det er et gjensidig påvirkningsforhold mellom folketall og antall arbeidsplasser.

Motivet for å splitte opp mulige årsaksforhold til vekst i strukturelle forhold og attraktivitet er at modellen skal være nyttig for dem som ønsker å påvirke utviklingen på eget sted. De strukturelle forholdene er naturligvis nyttige å kjenne til for å forstå drivkreftene for utviklingen, men det er forhold knyttet til attraktivitet som utgjør handlingsrommet, og som stedene kan gjøre noe med selv. 


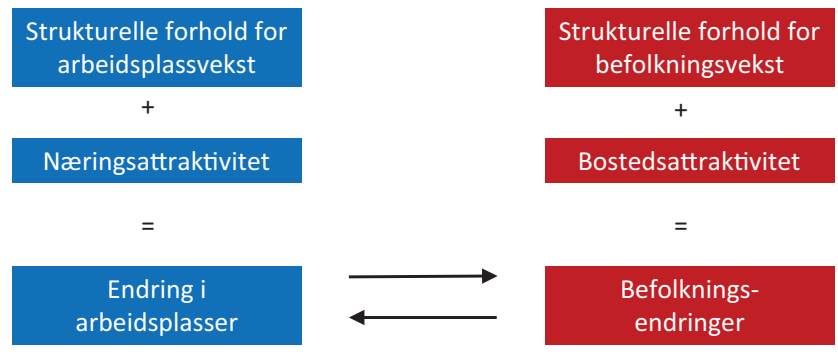

Figur 1.1 Prinsippskisse til attraktivitetsmodellen.

Det er mange aktører som ønsker å skape vekst på sine steder. Kommunene er nesten uten unntak ivrige etter å skape vekst i befolkning og arbeidsplasser. Det finnes et stort antall interkommunale institusjoner, regionråd og interkommunale næringsselskaper som er opprettet for å bidra til høyere vekst. Fylkeskommunene ønsker også å påvirke samfunnsutviklingen. Det private næringslivet er også opptatt av å skape vekst i sine områder, og er ofte organisert i næringsforeninger som arbeider for å bidra til vekst.

Attraktivitetsmodellen er utviklet for å være en støtte til slike aktører. Modellen skal ikke bare gi en teoretisk forståelse av hva som skaper vekst på et sted; ambisjonen er at den også skal kunne brukes som støtte til å utvikle strategier og tiltak som er vekstfremmende. Da er det viktig å fokusere på hva som er handlingsrommet. Hva kan stedene påvirke selv?

\subsection{Om attraktivitetsmodellen i en kunnskapskontekst}

Attraktivitetsmodellen er utviklet fra bunn uten å ha vært bygget på en bestemt eksisterende teori. Vi skal kort gjøre rede for hvordan attraktivitetsmodellen passer inn i kunnskapsfeltet på dette området. Det finnes mye forskning på hvorfor noen områder vokser mer enn andre, når det gjelder både næringslivets vekst og befolkningsvekst. Vi skal derfor omtale de delene av dette store kunnskapsfeltet som vi mener er mest nærliggende og relevant i denne sammenhengen.

Richard Florida synes å være en av de aller mest leste og kjente forskerne på dette feltet. Mange steder i Norge har helt eller delvis adoptert hans teorier, spesielt fra boka The Rise of the Creative Class, som kom ut i 2002. Florida mente å vise, gjennom empiriske analyser, at noen steder var mer attraktive for 
kreative mennesker. Denne attraktiviteten var igjen påvirket av stedenes egenskaper, som kunne påvirkes lokalt. Byenes estetiske egenskaper og forekomsten av ameniteter (en fellesbetegnelse på ulike tilbud og goder som kan gjøre steder attraktive) som de kreative satte pris på, var eksempler på egenskaper som fremmet stedenes attraktivitet. Samtidig mente Florida at såkalte kreative næringer hadde sterkere vekst enn andre. For slike kreative næringer er den viktigste innsatsfaktoren kreativ arbeidskraft. Dermed ville steder som var attraktive for kreative personer, også tiltrekke seg bedrifter i de vekstkraftige kreative næringene. Richard Floridas teorier er ganske skarpt kritisert av andre forskere og har derfor begrenset status i forskermiljøene, men teoriene har blitt flittig brukt mange steder i Norge og resten av verden. Idéen om at steder har ulike egenskaper som kan forklare hvorfor de tiltrekker seg innflytting i ulike grad, er i høyeste grad til stede i attraktivitetsmodellen også. Men vi skiller ikke mellom kreative innflyttere og andre. Vi finner heller ikke særlig stor støtte i empiriske data for Norge som støtter tesen om at kreative næringer vokser raskere enn andre. I vår modell har steder ulik tiltrekningskraft på innflytting generelt, ikke spesielt på kreative. Og tiltrekningskraften for tilflytning får bare innflytelse på den delen av arbeidsmarkedet som retter seg mot det lokale markedet, som kommunal virksomhet, butikker, bygg og anlegg, eiendom. Altså ikke de mest kreative næringene. Ifølge Florida var det de tre T-ene (Technology, Talent, Tolerance) som var nøkkelen til attraktivitet. Attraktivitetsmodellen fokuserer på tre B-er: bedrift, besøk og bosetting. Det må innrømmes at vi, da vi introduserte de tre B-ene, i det minste var inspirert av Floridas stil, om ikke innholdet hans.

Blant Floridas kritikere bør kanskje den utrolig produktive Edward L. Glaeser nevnes spesielt. I hans «Review of Richard Florida's The Rise of the Creative Class» går han god for mye av det Florida postulerer i boka, og da spesielt at det er vekstfremmende for steder å ha egenskaper som er tiltrekkende for innflyttere. Glaeser mener imidlertid at det er steders tiltrekningskraft for personer med høy utdanning som er utslagsgivende. Med Floridas eget datasett forsøker han med tilsynelatende hell å vise at det er utdanningsnivået som gir befolkningsvekst, og ikke de kriteriene Florida mener er viktige (bohemindeksen og andre). Her skiller vi lag med Glaeser i attraktivitetsmodellen. Vi har forsøkt på ulike måter og se om forskjeller i utdanningsnivå (eller forekomst av universitet eller høgskoler) i norske kommuner og regioner har noe å si for befolknings- eller næringslivsvekst. Hvis vi bare måler vekst mot 
én variabel, nemlig utdanningsnivå, er det tilsynelatende en sammenheng. Men setter vi i tillegg befolkningsstørrelse og næringsstruktur inn som variabel, forsvinner sammenhengen. Utdanningsnivået er dermed ikke en variabel $\mathrm{i}$ attraktivitetsmodellen.

Et annet prosjekt som bør nevnes i denne sammenhengen, er «The attractiveness of European regions and cities for residents and visitors». Dette var et prosjekt finansiert av EU-programmet ESPON. Som tittelen forteller, handler det om to av våre B-er: attraktivitet for besøk og bosetting. Dette arbeidet var, i likhet med attraktivitetsmodellen, sterkt fundamentert i empiriske analyser på regionalt nivå, men da med en helt annen regioninndeling. Regionene i dette prosjektet vil tilsvare landsdelsnivå i Norge. I attraktivitetsmodellen bryter vi data ned til kommunenivå i Norge. I dette prosjektet ble det også definert en empirisk basert modell (the ATTREG model) hvor flyttestrømmene ble påvirket av et sett med territorielle egenskaper. De territorielle egenskapene ble definert gjennom 19 indikatorer, som tilgjengelighet (transport/infrastruktur), kyst, øy, klima, utdanningsnivå, befolkningstetthet, hotellsenger, turistattraksjoner etc. I dette prosjektet ble det gjort et skille mellom eksogene faktorer (som stedene kan gjøre lite med) og endogene faktorer. Endogene faktorer omfatter det som betegnes som «policy instruments». Dette grepet er sammenliknbart med det vi gjorde i attraktivitetsmodellen. Det som omtales som eksogene faktorer i ATTREG-modellen kan tolkes som det vi kaller strukturelle forhold i attraktivitetsmodellen. Modellen i dette prosjektet er ganske forskjellig fra attraktivitetsmodellen. En likhet er at begge modellene skiller mellom strukturelle faktorer og faktorer som kan påvirkes. Den geografiske inndelingen er svært forskjellig i ATTREG-modellen og vår attraktivitetsmodell. Det betyr at det vil bli forskjellige resultat med hensyn til hvordan de samme faktorene påvirker nettoflyttingen. Faktorer som kan ha stor betydning for en enkelt kommune kan ofte ha liten betydning når vi ser på en landsdel. ATTREG-modellen har ikke arbeidsplassvekst som forklaringsvariabel for flyttestrømmer. Det er en vesentlig forskjell fra attraktivitetsmodellen. I attraktivitetsmodellen er arbeidsplassvekst en sentral forklaringsfaktor for flyttestrømmene. Etter vår mening vil en analyse av flyttestrømmer mellom regioner som utelater den kanskje viktigste faktoren, arbeidsplassvekst, ikke ha særlig verdi. Dermed er både selve modellene og den geografiske inndelingen i ATTREG så forskjellige at de to modellene vanskelig kan sammenliknes. Som en kuriositet kan vi nevne at Telemarksforsking var med i et konsortium som konkurrerte om dette 
prosjektet. Det forskerkonsortiet vi tilhørte, kom dessverre bare på andreplass av de ti som konkurrerte om å få prosjektet.

I Sverige satte regjeringen i gang «Nationell strategi for tilväxt och attraktivitet 2015-2020». På typisk svensk vis gikk de grundig til verks, og den statlige institusjonen Tillväxtanalys ga ut rapporten «Varför är vissa platser mer attraktiva för boende än andra?». I denne rapporten har de innledningsvis en diskusjon om hva attraktivitet er, og slår fast at attraktivitet handler om attraktivitet for «boende, besök och näringslivsattraktivitet». Altså våre tre B-er. Dernest har de en gjennomgang av internasjonal forskning på feltet. De peker på svensk forskning, der arbeidsmarkedet har en klar betydning for flyttestrømmene. I tillegg viser de til at forskningslitteraturen er rik på studier av hvilken betydning ulike ameniteter har.

I artikkelen «What matters for internal migration, jobs or amenities?» (Niedomysl \& Clark 2014) har forfatterne gått gjennom forskningslitteraturen og sett på om vi kan konkludere om det er arbeidsplasser eller ameniteter som er den viktigste drivkraften for regional vekst. De viser til at ameniteter spenner over et stort antall ulike faktorer, og at begrepet ameniteter ikke er veldefinert. De mener at det ikke er et spørsmål om enten-eller, men at det er mest fruktbart å se regional vekst som et komplekst samspill mellom arbeidsplassvekst, ameniteterogsosialefaktorer. Attraktivitetsmodellen og de empiriske analysene som er gjennomført med bruk av denne modellen, viser at arbeidsplassveksten har en krystallklar og veldefinert effekt på flyttestrømmer. Steders ameniteter kan imidlertid være en av flere faktorer som kan påvirke flyttestrømmene i positiv eller negativ retning. Steders ameniteter kan da være med på å forklare hvorfor noen steder har bedre flyttetall enn arbeidsplassveksten skulle tilsi, de kan altså være en forklaringsfaktor for steders bostedsattraktivitet. Som Niedomysl og Clark sier i artikkelen, er ameniteter et sett av mange ulike faktorer. Dermed vil en enkelt amenitet vanskelig få avgjørende betydning.

Ellers finnes det en rekke forskningspublikasjoner som handler om enkeltfaktorers betydning for regional vekst. I artikkelen «Amenities as a Factor in Regional Growth» (Ullman 1954) hevdes det at et godt klima har en signifikant betydning for flyttestrømmer i USA. Videre finnes det forskning som viser at gjennomsnittsinntekten har betydning, og at lokalisering av høgskole eller universitet er positivt («Flyttning och pendling i Sverige» (SOU 2007:35)). Lista over forskning som viser betydningen av slike enkeltfaktorer, 
kan gjøres svært lang. Vi har forsøkt å se om klima har en selvstendig betydning for flyttestrømmer mellom norske kommuner, men uten hell. Også lokalisering av høgskole og universitet har vi forsøkt å analysere virkningen av, uten å finne noe («Hva betyr det for et sted å ha en høgskole?», Vareide \& Nygaard 2015). Hadde vi funnet at klima eller lokalisering av høgskole hadde hatt en signifikant betydning, hadde dette vært å anse som strukturelle betingelser som burde blitt inkludert i attraktivitetsmodellen.

Vi har så langt kort redegjort for forskning på flytting på regionalt nivå som har relevans for attraktivitetsmodellen. Attraktivitetsmodellen behandler også arbeidsplassveksten som en endogen faktor. Dermed blir forskning på hva som skaper økonomisk vekst, materialisert som arbeidsplassvekst, også relevant. Her finnes det et enda større felt av forskningslitteratur.

I attraktivitetsmodellen er bruk av shift/share-analyser sentralt. Shift/shareanalyser er en klassisk metode for å skille mellom ulike drivkrefter for vekst: nasjonal vekst, strukturell vekst og regional vekst. Metoden ble beskrevet så tidlig som på 40-tallet (Daniel Creamer 1942). Metoden tar utgangspunkt i at ulike steder har ulik fordeling av bransjer. Man sammenlikner så veksten i de ulike bransjene på det aktuelle stedet med bransjenes vekst nasjonalt. Operasjonen ender opp med å dekomponere veksten på stedet i tre drivkrefter: den nasjonale veksten, effekten av bransjestrukturen og den regionale veksten. Den første effekten betegner vi som et strukturelt forhold, ettersom et sted ikke kan påvirke den nasjonale veksten særlig mye. Den nasjonale effekten endres raskt etter nasjonale og internasjonale konjunkturer. Effekten av bransjestrukturen regner vi også som et strukturelt forhold. Steder kan i praksis ikke påvirke bransjestrukturen i særlig grad på kort eller mellomlang sikt. Steder med en stor andel av arbeidsplasser i bransjer som har nedgang, vil få en negativ bransjeeffekt, mens andre steder, som har mange arbeidsplasser i vekstbransjer, får en positiv bransjeeffekt. Den siste faktoren, regional vekst justert for nasjonal vekst og effekten av bransjestrukturen, er dermed den faktoren som vi er spesielt interessert i.

Ulike former for klyngeteorier har fått bred utbredelse. Amerikaneren Paul Krugman regnes som en av pionerene innen klyngeteori. Han vektla lave transportkostnader og konsentrasjon av bedrifter vertikalt og horisontalt i verdikjeden som årsak til at noen regioner fikk høyere vekst og produktivitet. Forhold som tilgjengelighet (transport) og ulike teorier om agglomerasjoner og klynger burde tilsi at store arbeidsmarkedsregioner hadde systematisk 
større vekst enn små og isolerte regioner. I Norge har det blitt gjort mange analyser av betydningen av regionforstørring, spesielt i forbindelse med store veiutbygginger, for eksempel fergefri E39. Flere forskningsmiljøer i Norge, blant annet BI og Samfunns- og næringslivsforskning (SNF), har beregnet store økonomiske effekter av å binde ulike arbeidsmarkeder sammen gjennom investeringer i infrastruktur. En positiv sammenheng mellom produktivitet og arbeidsmarkedsstørrelse står sentralt i disse beregningene. Dersom størrelsen på arbeidsmarkedene har en vesentlig betydning for produktiviteten i næringslivet, burde store arbeidsmarkeder også vokse raskere. I våre analyser finner vi riktignok at store arbeidsmarkeder har sterkere vekst i antall arbeidsplasser enn små. Men årsaken synes å være at de store arbeidsmarkedene i Norge har en bransjestruktur med en konsentrasjon av vekstbransjer, mens de fleste små arbeidsmarkeder har mesteparten av næringslivet i bransjer med lav vekst. I tillegg får de store arbeidsmarkedene en tilflytting av mennesker fra de små arbeidsmarkedene. Det synes å være et resultat av unge personers bostedspreferanser. Den betydningen arbeidsmarkedenes størrelse har for arbeidsplassveksten i næringslivet, faller bort når vi samtidig tar med effekten av bransjesammensetningen og befolkningsveksten. Dermed blir også effekten av investeringer $\mathrm{i}$ infrastruktur ganske lav når vi anvender vår attraktivitetsmodell, slik det for eksempel er gjort i Telemarksforskings notat «Hva betyr en fast forbindelse over Oslofjorden?» (Vareide 2014).

Triple helix-teorier er også mye brukt og sitert i mange regionale utviklingsplaner. Triple-helix omhandler tre pilarer for regional vekst: næringslivet, det offentlige og akademia. Etzkowitz (1995) regnes som opphavet til begrepet. Regionale innovasjonssystemer er et begrep som er nær knyttet til triple helix. Regionale innovasjonssystemer er noe som kan skapes. Det er dermed ikke en strukturell faktor, men en faktor som kan forklare attraktivitet. Men steder uten høgskoler, universiteter eller forskningsmiljøer, vil jo mangle en av de tre pilarene. Dermed burde lokalisering av slike kunnskapsinstitusjoner logisk sett være en viktig strukturell faktor. Vi har forsøkt å anvende attraktivitetsmodellen for å undersøke betydningen av å ha en høgskole eller universitet i notatet «Hva betyr det for et sted å ha en høgskole?» (Vareide og Nygaard 2015). Vi fant at lokalisering av en høgskole i en kommune ikke hadde noen signifikant betydning verken for befolknings- eller arbeidsplassvekst. 
Betydningen av sosial kapital blir også tillagt betydning for regional vekst. Sosial kapital er også elementer i klyngeteori og triple helix. Utdanningsnivå kan være eksempel på en type sosial kapital som bidrar til vekst.

Forskningslitteraturen kan derfor inspirere til et mangfold av faktorer som fører til at noen steder har sterkere vekst enn andre. Størrelsen til det funksjonelle arbeidsmarkedet som stedet ligger innenfor, sentralitet og tilgjengelighet for transport, forekomst av universitet, høgskoler og forskningsinstitusjoner og utdanningsnivå er eksempler på stedlige egenskaper som kan tenkes å påvirke veksten. Dette er egenskaper ved stedene som i liten grad kan påvirkes på kort sikt, og som kunne vært lagt inn som strukturelle forhold for arbeidsplassvekst. Teorien på området gir dermed mange eksempler på faktorer som kan inngå i vår modell. Vi har testet de fleste av disse faktorene for å se om de gir et systematisk og signifikant bidrag til å forklare forskjeller i arbeidsplassvekst i norske kommuner og regioner mellom 2000 og 2015. Noe overraskende har vi ikke funnet at disse faktorene har noen signifikant betydning. Noe av årsaken er at vi har lett etter regional vekst etter å ha justert for bransjestruktur og nasjonal vekst med bruk av den omtalte shift/sharemetoden. Attraktivitetsmodellen gir dermed ganske andre svar på hva som skaper vekst, enn mye av den øvrige teorien på området. 



\section{KAPITTEL 2}

\section{Regionale vekstmønstre}

I dette kapitlet skal vi vise hvordan de regionale vekstmønstrene har vært i Norge etter 2000. Hvilke steder har hatt sterkest befolkningsvekst, og hvilke har fătt nedgang? Hvilke steder har hatt sterkest og svakest vekst i antall arbeidsplasser? Er det de samme stedene som har hatt arbeidsplassvekst, som har hatt befolkningsvekst? Alle data vi har brukt i dette kapitlet, kommer fra SSB. Befolkningsdata er hentet fra statistikkbanken, mens data for arbeidsplasser er fra registerbasert sysselsettingsstatistikk.

Vi skal også gå inn på de ulike komponentene i befolknings- og arbeidsplassutviklingen. Hensikten er å gi et overblikk over de regionale variasjonene i vekst i Norge. Det vil også være trekk i utviklingen som vi har brukt for å spesifisere og utforme modellen som vi skal presentere i de neste kapitlene.

\subsection{Befolkningsvekst}

Vi skal først se på mønstrene i befolkningsveksten i kommunene i Norge. I kartene i figur 2.1 ser vi befolkningsveksten i to perioder, og et kart som viser endringen i vekstrate mellom de to periodene.

Kartene viser et velkjent mønster for perioden 2000-2006. Kommunene rundt de største byene vokste mest. I den første perioden hadde mange av de perifere kommunene nedgang. I den andre perioden, 2007-2014, fikk langt færre kommuner nedgang, men fremdeles finner vi nedgangskommunene i periferien. Årsaken til at befolkningsveksten i de to periodene er forskjellig, er at innvandringen til Norge økte, som følge av økt arbeidsinnvandring fra land i Schengen-området.

Har dette ført til mer eller mindre sentralisering? Det siste kartet viser endringene i vekstratene mellom de to periodene. Det er ikke lett å se noen mønstre i endringene. Det er kommuner med nedgang og vekst $i$ alle landsdeler. Det er riktignok blitt langt færre kommuner med befolkningsnedgang, 


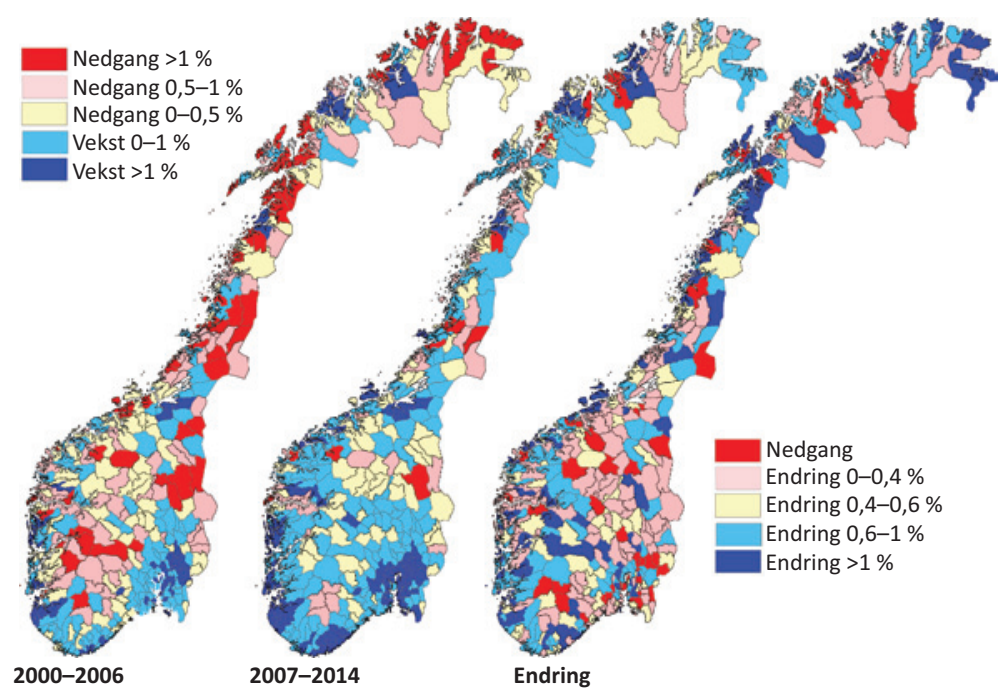

Figur 2.1 Årlige vekstrater i folketallet i kommunene i perioden 2000-2006 og 2007-2014, samt endringen i vekstrater mellom de to periodene.

men det er ikke lett å se at endringene er forskjellige mellom landsdeler, eller mellom sentrum og periferi.

Mønstrene vi ser, tyder på at sentraliseringen fortsetter, i betydningen at de sentrale områdene som hadde størst befolkningsvekst tidligere, også har den største befolkningsveksten i den siste perioden. Innvandringen har bidratt til å heve nivået for befolkningsveksten ganske likt over hele landet.

\subsubsection{Mønstre i befolkningsvekst i regionene}

Vi også skal se på hvordan befolkningsveksten fordeler seg mellom regioner. Vi bruker en regioninndeling der kommunene blir gruppert i regioner etter politiske samarbeidskonstellasjoner i form av regionråd eller interkommunale næringsselskaper. I de fleste fylkene er det en definert regioninndeling som brukes av fylkeskommunene. I noen få områder, for eksempel Finnmark og Helgeland, har vi definert regionene selv, men i de fleste områdene danner kommunene veldefinerte regioner. Vi har delt de 428 kommunene inn i 84 slike politiske regioner.

I mange tilfeller vil mønstre tre klarere fram når vi bruker regioninndeling $\mathrm{i}$ stedet for kommuneinndeling. Når vi ser på kartene over befolkningsveksten i de to periodene og endringen fra periode til periode, ser vi at mange av 


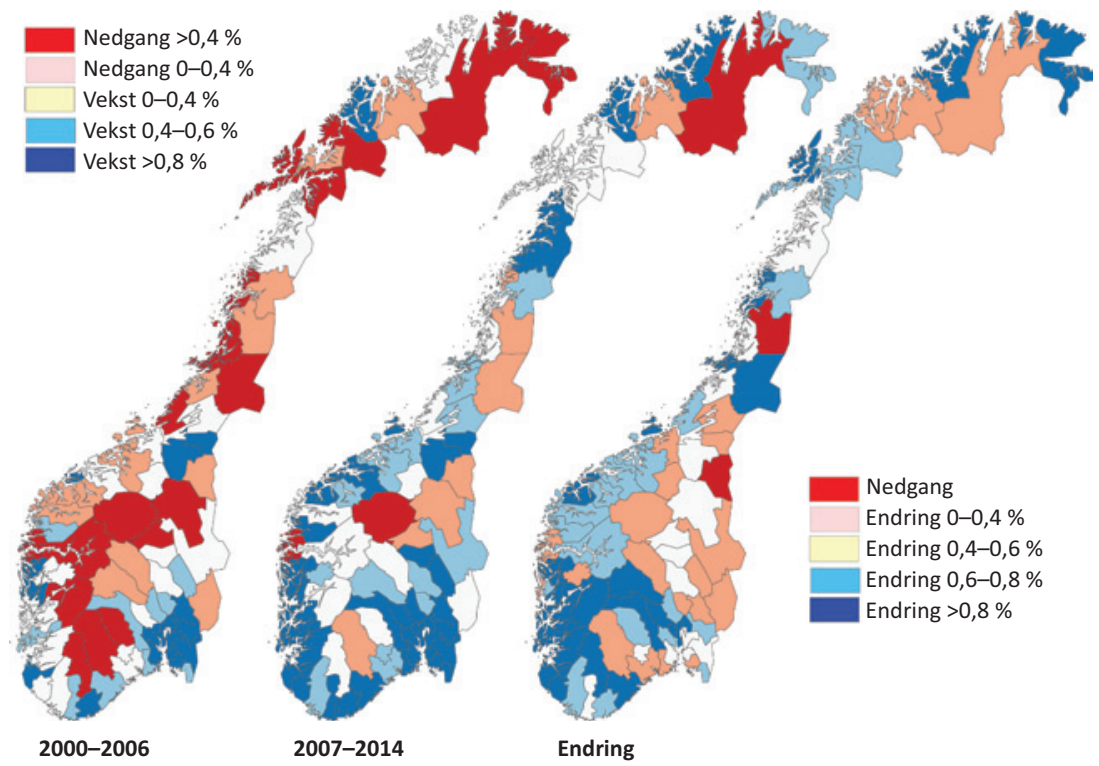

Figur 2.2 Årlige vekstrater i folketallet i regionene i perioden 2000-2006 og 2007-2014, samt endringen i vekstrater mellom de to periodene.

regionene på Vestlandet har fått økt befolkningsveksten mest fra første til andre periode. Innlandet (Hedmark og Oppland) har ingen regioner som er blant regionene med størst økning i befolkningsveksten.

Videre skal vi se nærmere på hvordan befolkningsendringene kan dekomponeres i fødselsbalanse, innenlands flytting og nettoinnvandring. Senere skal vi se nærmere på drivkreftene bak befolkningsveksten. Vi vil da vise hvordan strukturelle trekk i næringsutviklingen har gitt ulike betingelser for arbeidsplassvekst mellom de ulike områdene.

\subsubsection{Hvordan befolkningsendringer kan dekomponeres}

Befolkningsendringer skjer som følge av seks ulike komponenter:

- fødte

- døde

- innflytting innenlands

- utflytting innenlands 
- $\quad$ innvandring

- utvandring

De seks komponentene danner tre par:

- fødselsoverskudd som er lik fødte fratrukket døde

- netto innenlands flytting, som er innenlands innflytting minus utflytting

- netto innvandring, som er innvandring fratrukket utvandring

Alle disse komponentene bidrar til endringer i befolkningen, men i ulik grad på ulike steder. Vi skal se på hvordan de regionale mønstrene i befolkningsutviklingen har blitt påvirket av disse komponentene siden 2000.

\subsubsection{Fødselsoverskuddet}

Fødselsoverskudd er antall fødte minus antall døde. Når vi skal sammenlikne ulike områder, er det mest hensiktsmessig å se på variasjoner i fødselsoverskuddet i prosent av folketallet i begynnelsen av perioden. I kartene i figur 2.3 ser vi hvordan fødselsoverskuddet varierer mellom kommunene i Norge.

Kartene i figur 2.3 viser at mønstrene i fødselsbalansen er svært stabile over tid. Det er liten forskjell på variasjonene i kommunenes fødselsbalanse mellom de to periodene. Det er høy positiv fødselsbalanse i de store byene og i omkringliggende kommuner og negativ fødselsbalanse i de fleste perifere kommunene.

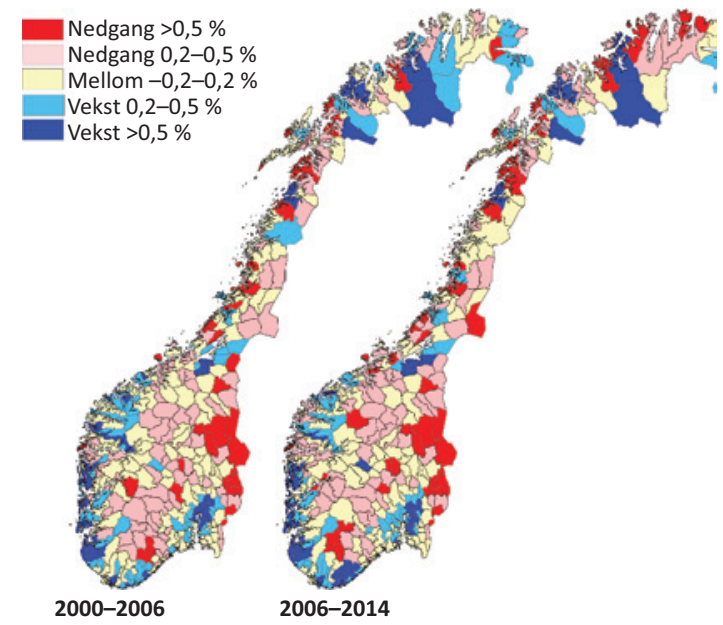

Figur 2.3 Fødselsbalansens bidrag til årlig befolkningsvekst. 
Alders- og kjønnsfordelingen betyr mye for fødselsbalansen. Hvis det er en stor andel kvinner i fødedyktig alder, bidrar det til at det blir flere fødte som andel av befolkningen. Samtidig vil en stor andel eldre føre til høyere dødelighet. Begge disse faktorene blir påvirket av flyttingen. Det er i hovedsak unge mennesker som flytter, og det gjør at steder som over tid har hatt netto innflytting, både får flere kvinner i fødedyktig alder og en mindre andel eldre. Dermed vil nettoflyttingen påvirke fødselsbalansen over tid.

Det er også regionale forskjeller mellom landsdelene når det gjelder fruktbarhet. Fruktbarheten måles som antall barn en gjennomsnittskvinne føder i løpet av livet. Fylker som Hedmark, Oppland og Telemark har lav fruktbarhet, mens Sogn og Fjordane og Rogaland er fylker med høy fruktbarhet.

Tabell 2.1 Fruktbarhetstall i fylkene i ulike tiår, avvik fra landsgjennomsnittet.

\begin{tabular}{lcccccc}
\hline & 1960 & 1970 & 1980 & 1990 & 2000 & 2010 \\
\hline Østfold & $-0,20$ & $-0,10$ & $-0,16$ & $-0,15$ & $-0,07$ & $-0,06$ \\
Akershus & $-0,13$ & $-0,17$ & $-0,11$ & $-0,05$ & 0,03 & 0,06 \\
Oslo & $-0,73$ & $-0,50$ & $-0,26$ & $-0,17$ & $-0,09$ & $-0,11$ \\
Hedmark & $-0,16$ & $-0,18$ & $-0,18$ & $-0,15$ & $-0,11$ & $-0,10$ \\
Oppland & $-0,08$ & $-0,09$ & $-0,17$ & $-0,15$ & $-0,11$ & $-0,06$ \\
Buskerud & $-0,23$ & $-0,14$ & $-0,11$ & $-0,13$ & $-0,06$ & $-0,06$ \\
Vestfold & $-0,17$ & $-0,10$ & $-0,09$ & $-0,10$ & $-0,10$ & $-0,09$ \\
Telemark & $-0,13$ & $-0,05$ & $-0,03$ & $-0,11$ & $-0,13$ & $-0,07$ \\
Aust-Agder & 0,13 & 0,23 & 0,13 & 0,03 & $-0,03$ & 0,05 \\
Vest-Agder & 0,24 & 0,29 & 0,22 & 0,13 & 0,08 & 0,12 \\
Rogaland & 0,39 & 0,32 & 0,29 & 0,24 & 0,19 & 0,18 \\
Hordaland & 0,22 & 0,17 & 0,15 & 0,13 & 0,08 & 0,05 \\
Sogn og Fjordane & 0,52 & 0,42 & 0,27 & 0,24 & 0,20 & 0,14 \\
Møre og Romsdal & 0,44 & 0,23 & 0,17 & 0,11 & 0,12 & 0,07 \\
Sør-Trøndelag & 0,11 & 0,08 & $-0,01$ & 0,02 & 0,00 & $-0,01$ \\
Nord-Trøndelag & 0,37 & 0,23 & 0,13 & 0,14 & 0,15 & 0,14 \\
Nordland & 0,41 & 0,20 & 0,11 & 0,09 & 0,02 & 0,03 \\
Troms & 0,57 & 0,22 & 0,08 & 0,08 & 0,01 & $-0,03$ \\
Finnmark & 0,68 & 0,36 & 0,11 & 0,18 & 0,07 & 0,01 \\
\hline
\end{tabular}


Fruktbarhetstallene varierer både over tid og i geografien. For å få fram de geografiske mønstrene kan vi se på hvordan fruktbarhetstallene avviker fra landsgjennomsnittet i de ulike fylkene de siste tiårene. Tabell 2.1 viser dette.

SSB forklarer fruktbarhetstallene slik: Samlet fruktbarhetstall er summen av 1-årige aldersavhengige fruktbarhetsrater 15-49 år. Antall barn hver kvinne kommer til å føde under forutsetning av at fruktbarhetsmønsteret $i$ perioden varer ved, og at dødsfall ikke forekommer.

På 6o- og 70-tallet var de geografiske forskjellene i fruktbarhet svært store. Etter hvert har fruktbarhetstallene blitt mye jevnere fordelt mellom fylkene. Noen fylker, som Rogaland, Sogn og Fjordane og Nord-Trøndelag, har fremdeles høyere fruktbarhet. Fylkene på Østlandet har stort sett hatt lavere fruktbarhet enn andre deler av landet, med unntak av Akershus, hvor kvinnene nå har blitt mer fruktbare enn gjennomsnittet. De tre nordligste fylkene hadde mye høyere fruktbarhet enn gjennomsnittet tidligere, men har nå en fruktbarhet som ligger nær gjennomsnittet.

Selv om forskjellene i fruktbarhet har blitt mindre, får kvinnene i Rogaland fremdeles 0,3 flere barn enn kvinnene i Oslo. Variasjon i fruktbarhet påvirker dermed befolkningsveksten ganske mye fremdeles.

Men selv om forskjeller i fruktbarhet har en klar betydning for å forklare variasjoner i befolkningsvekst, vil vi nå forlate dette temaet i denne boka. Det er fordi det å påvirke kvinners fruktbarhet ikke er et tema for dem som driver med regional utvikling. Det kan være mange årsaker til det, ikke minst mangelen på effektive virkemidler og tiltak.

\subsubsection{Flytting og alder}

Vi skal se litt på hvordan flytting påvirkes av alder. I figur 2.4 kan vi se hvilke alderstrinn som flytter hyppigst. Personer mellom 20 og 30 år flytter klart mest hyppig. Flyttehyppigheten avtar med alder, men det er forholdsvis mange små barn som er med på flyttelassene. Fra 2000 til 2014 har det blitt en større mobilitet i befolkningen over 15 år, mens det er en mindre andel av barn under 15 som flytter.

Figur 2.4 viser at de fleste som flytter, er under 40 år. Det betyr at steder som har stor innflytting, i regelen forynger befolkningen. Slike steder vil da fă lavere dødelighet, fordi andelen eldre blir lavere. Samtidig får slike steder flere 


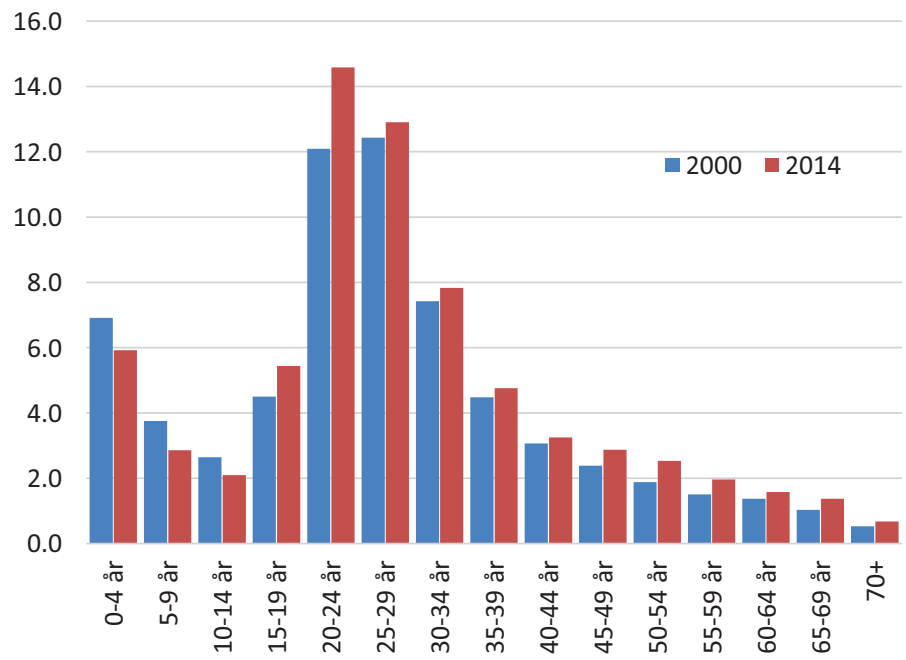

Figur 2.4 Prosentvis andel som flytter over kommunegrense i ulike alderstrinn.

kvinner i fødedyktig alder, noe som øker antall fødsler. Steder med netto innflytting over mange år vil dermed få et høyere fødselsoverskudd.

På steder med netto utflytting vil befolkningen tappes for yngre. Det blir da en høyere andel eldre i befolkningen og færre kvinner som føder. Slike steder vil dermed gradvis få en stadig mer negativ fødselsbalanse.

Fødselsbalansen henger dermed nær sammen med nettoflyttingen. Det gjør at vi fokuserer på flyttemønstrene når vi skal analysere drivkreftene for befolkningsvekst.

\subsubsection{Flytting og kjønn}

Er det store forskjeller på flyttemønstrene mellom kjønn? Det er noen små forskjeller på mobiliteten til menn og kvinner. Kvinner er mer mobile enn menn mellom 15 og 25 år, mens menn er mer mobile etter 25. Kanskje henger den høyere mobiliteten til kvinner mellom 15 og 25 år sammen med at kvinner i høyere grad enn menn tar høyere utdanning. Ser vi alle aldersgrupper under ett, er menn litt mer mobile enn kvinner. Forskjellene er ganske små.

En kan ikke se bort fra at det er kjønnsforskjeller mellom drivkrefter for kvinners og menns flytting. Kanskje tiltrekkes de av forskjellige egenskaper ved stedene? Arbeidsmarkedet er også sterkt kjønnssegregert. Steder med sterk 


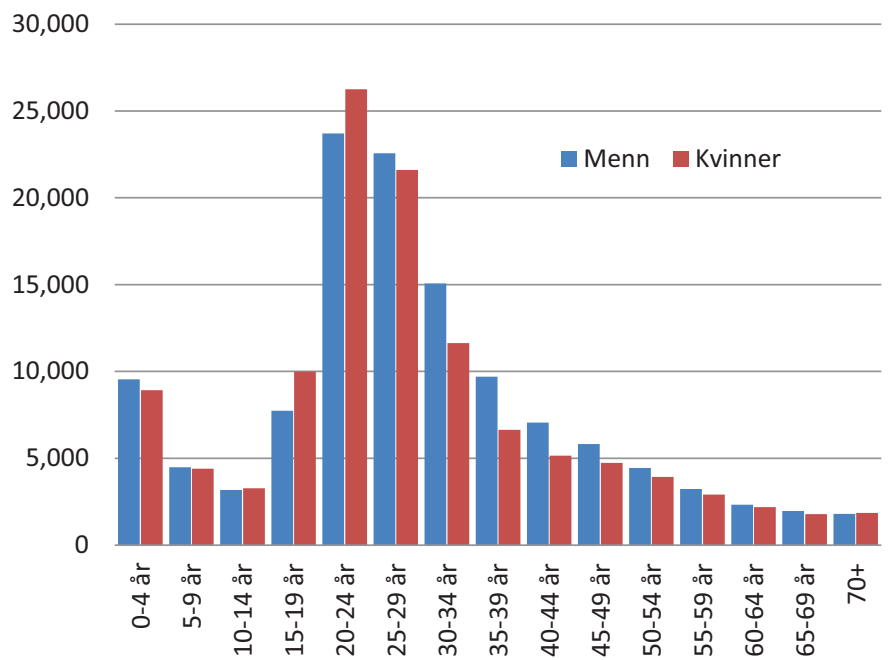

Figur 2.5 Prosentvis andel som flytter over kommunegrense i ulike alderstrinn. Kvinner og menn, 2014.

vekst $\mathrm{i}$ industriarbeidsplasser vil dermed i størst grad trekke til seg mannlige innflyttere, mens andre steder med sterk vekst i arbeidsplasser i helse- eller undervisningssektoren kanskje vil trekke til seg et flertall av kvinner.

Vi har likevel lagt til grunn at det er de samme drivkreftene som påvirker flyttingen mellom steder, uavhengig av kjønn. Det å splitte opp analysene mellom kjønn vil gjøre modellen og analysene langt mer komplisert. Det vil kanskje være noe som vi kan analysere i et annet prosjekt.

\subsubsection{Innenlands nettoflytting}

Innenlands nettoflytting til en region er antall personer som flytter inn fra en annen norsk region, fratrukket antall personer som flytter ut en annen region i Norge.

Den innenlandske flyttingen er vist i kartene i figur 2.6. Det er brukt samme skalering som i i kartene i figur 2.3, som viste variasjonene i fødselsbalansen. Vi kan se at det er svært mange kommuner som har et innenlands flyttetap. Det er de rosa og røde kommunene i figuren. Det er et tilsvarende lite antall kommuner som har en gevinst av den innenlandske flyttingen. Innenlands flytting er et nullsumspill, så i utgangspunktet burde det være omtrent like mange blå som røde kommuner. De kommunene som har netto innflytting fra andre norske kommuner, er imidlertid mye mer folkerike enn de kommunene som 


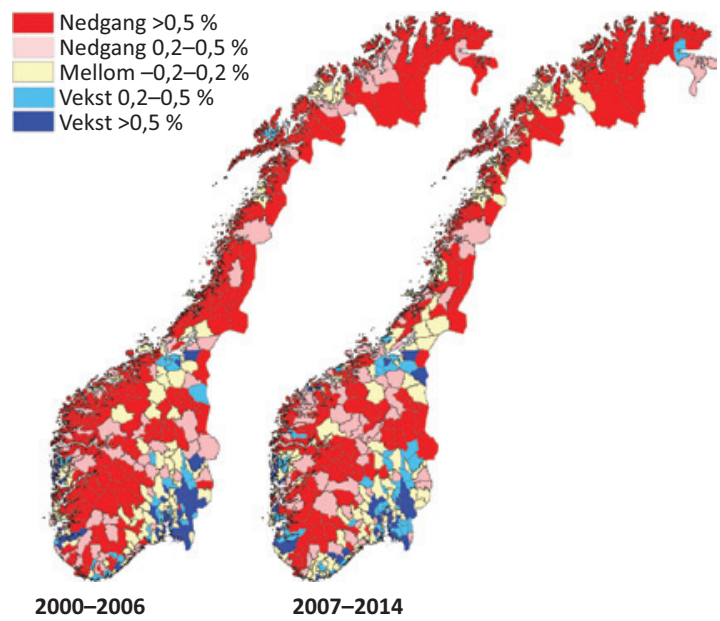

Figur 2.6 Den innenlandske nettoflyttingens bidrag til årlig befolkningsvekst.

har netto utflytting. Dermed blir den innenlandske flyttegevinsten konsentrert til få kommuner. Noen ganske få, store kommuner stikker av med den innenlandske flyttegevinsten.

Vi har dermed hatt en utvikling hvor ganske få kommuner vokser på bekostning av mange små. Det er det mønsteret vi vanligvis omtaler som sentralisering. Men hva er det som driver denne utviklingen? Er det økonomi, arbeidsplasser eller unges preferanser for det «urbane»? Det skal vi forsøke å gi svar på.

\subsubsection{Innvandring}

Nettoinnvandring er antall personer som flytter inn til et norsk sted fra utlandet, fratrukket antall personer som flytter fra et norsk sted til utlandet. Det er uavhengig av nasjonaliteten til personene.

Nettoinnvandringen til kommunene er vist i kartene i figur 2.7. Vi kan se at det i begge periodene er snakk om varierende vekstbidrag fra nettoinnvandringen. I den siste perioden har de fleste kommunene et nettobidrag fra innvandring som tilsvarer mer enn 0,5 prosent årlig befolkningsvekst. Det er vanskelig å se noen mønstre i innvandringen, og for sikkerhets skyld har vi laget kartet over innvandring i den siste perioden $i$ en annen skala, som skiller bedre mellom kommunene. Heller ikke i det tredje kartet er det mulig å se særlige mønstre. Det betyr at den økte innvandringen 


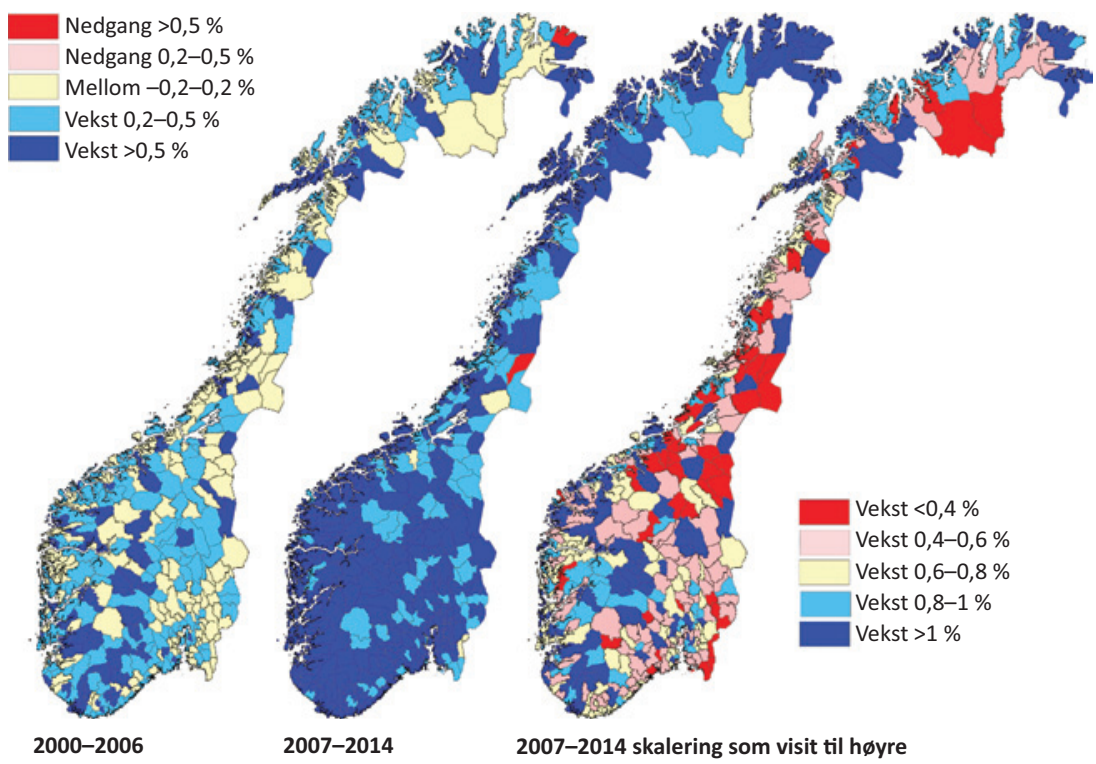

Figur 2.7 Nettoinnvandringens bidrag til årlig befolkningsvekst.

etter 2007 har fordelt seg over hele landet, uten noen synlige regionale mønstre.

Så langt har vi sett at sentraliseringen av bosettingen i stor grad skyldes nettoflyttingen innenlands. Fødselsbalansen virker også sentraliserende, men er forårsaket av at de kommunene som har hatt netto innflytting over en lang periode, også har fått et stort positivt fødselsoverskudd som følge av denne innflyttingen. Nettoinnvandringen har ikke virket sentraliserende, men synes å fordele seg ganske jevnt over hele landet.

\subsubsection{Innvandringsmønstre regioner}

Figur 2.8 viser nettoinnvandringen til regionene i de samme periodene. I den første perioden kan det se ut til at mange regioner med høyest innvandring er typiske distriktsregioner. I denne perioden var en stor del av dem som innvandret, flyktninger.

I den siste perioden har de fleste regionene et nettobidrag fra innvandring som tilsvarer mer enn 0,5 prosent årlig befolkningsvekst. Det er vanskelig å se noen mønstre i innvandringen, og for sikkerhets skyld har vi laget kartet over 


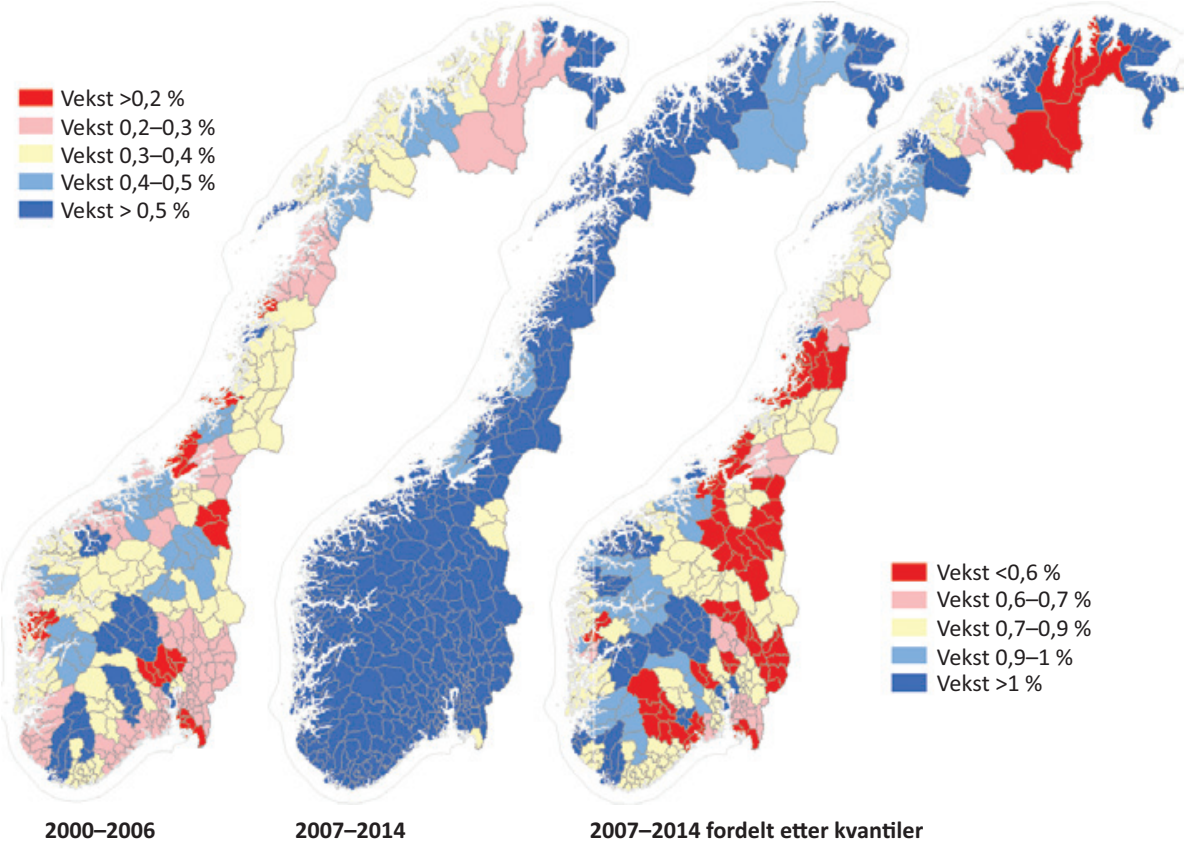

Figur 2.8 Nettoinnvandringens bidrag til årlig befolkningsvekst.

innvandring i den siste perioden i en annen skala i tillegg, som skiller bedre mellom regionene.

Det kan se ut til at det har vært høyere nettoinnvandring til Agder og Vestlandet, og noe mindre nettoinnvandring til Østlandet og Trøndelag. I den siste perioden har det vært mest arbeidsinnvandring. Det kan ha ført til at nettoinnvandringen har blitt mer knyttet til arbeidsplassvekst enn tidligere.

I figur 2.8 ser vi hvordan Norges befolkningsvekst har blitt påvirket av fødselsbalansen og nettoinnvandringen. Fødselsbalansen har vært ganske stabil. Nettoinnvandringen skjøt fart i løpet av 2007. Innvandringen til Norge skiftet også karakter. Før 2007 var en stor andel av innvandrerne flyktninger, mens etter 2007 har majoriteten av innvandringen skyldtes arbeidsinnvandrere fra Schengenområdet. Dette skiftet har hatt stor betydning, og det er årsaken til at vi så langt har skilt mellom perioden fra 2000 til og med 2006, og perioden fra 2007 og utover.

Kartene vi har sett, kan tolkes som at innvandringen har gitt et positivt skift til befolkningsveksten over hele landet. Det kan tolkes som at mekanismene 


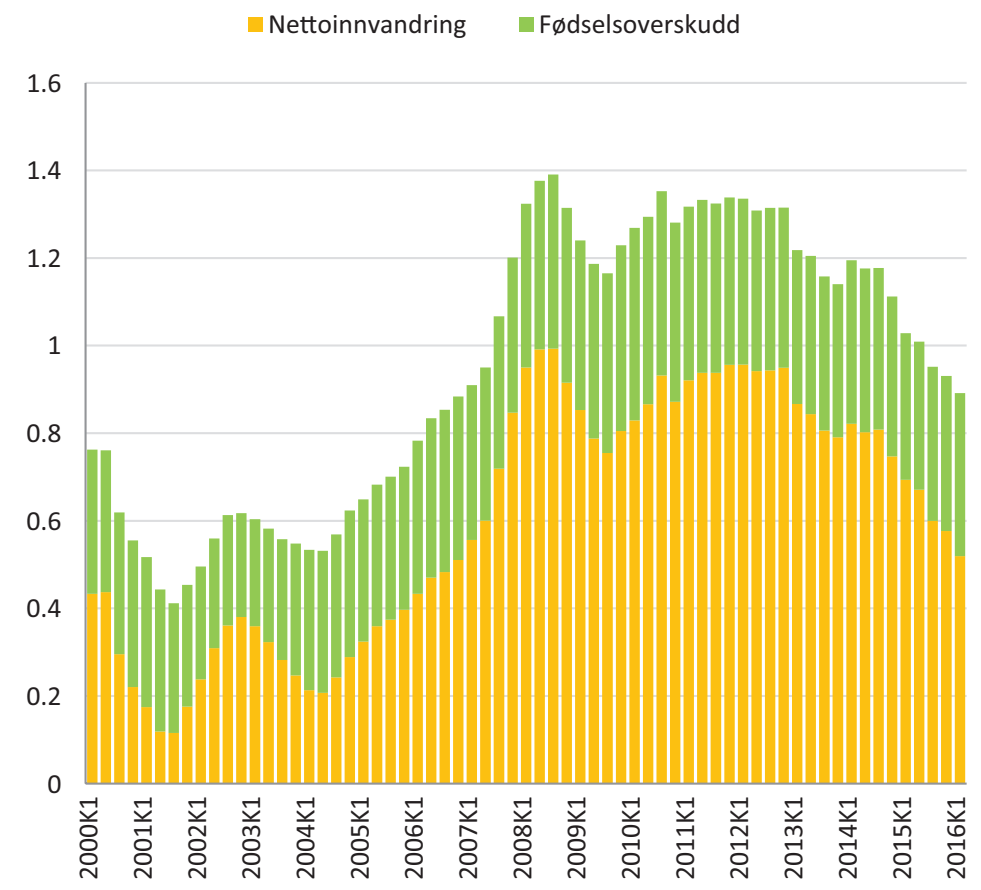

Figur 2.9 Prosentvis bidrag til befolkningsveksten i Norge fra fødselsbalanse og netto innvandring de siste 12 måneder.

for at norske steder har ulik vekst, er de samme som tidligere, men med den forskjellen at alle steder har fått et positivt skift i nettoflyttingen. Det vil si at vi i prinsippet kan ha samme modell for utviklingen i hele perioden, med Norges nettoinnvandring som en eksogen faktor som påvirker alle steder likt.

Det er også et tydelig trekk i figuren at nettoinnvandringen til Norge har hatt en synkende trend de tre siste årene. Det er i tråd med SSBs framskrivinger, men nedgangen har skjedd enda raskere enn i SSBs middelframskrivinger fra 2014. Utviklingen i Norges nettoinnvandring får stor betydning for framtidig befolkningsvekst i Norge og er et sentralt element når vi skal lage scenarioer for utviklingen basert på attraktivitetsmodellen. Det skal vi vise senere i denne boka.

\subsubsection{Samlet nettoflytting}

Hvis vi legger sammen netto innenlands flytting og netto innvandring, får vi samlet nettoflytting. I kartene under ser vi hvordan den samlede nettoflyttingen har bidratt til befolkningsveksten i de to periodene. 


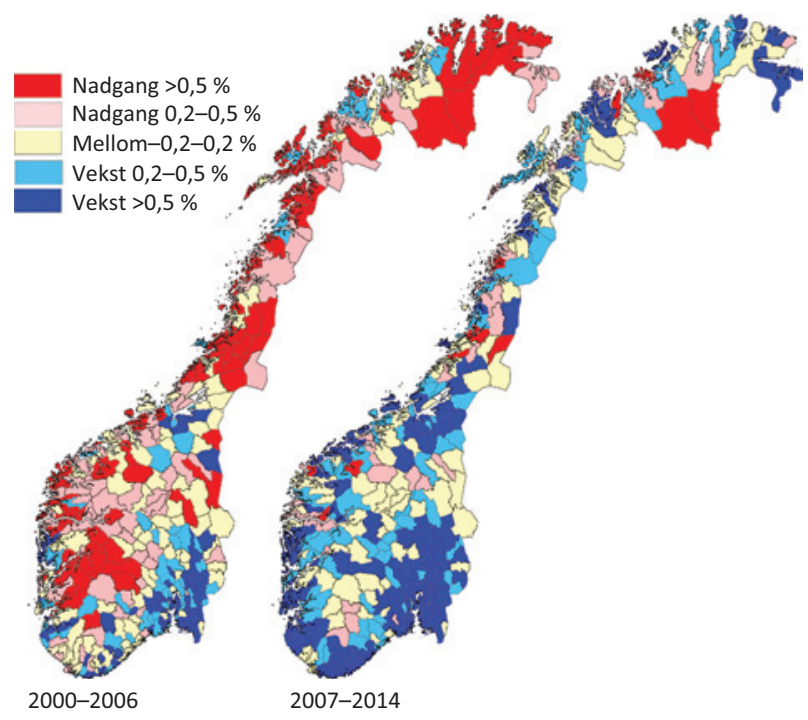

Figur 2.10 Nettoflytting inkludert innvandring.

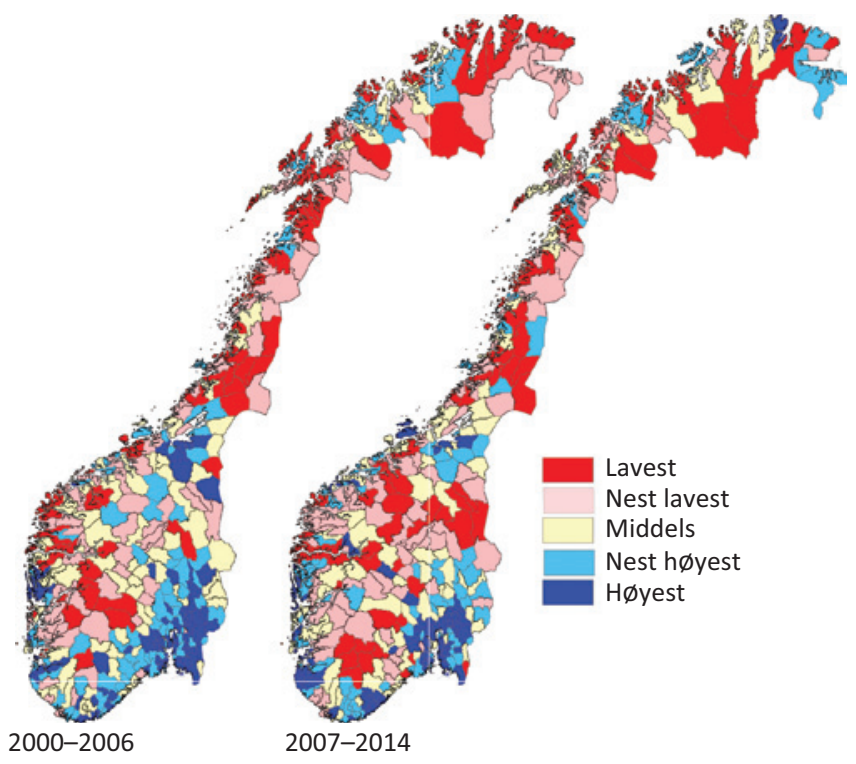

Figur 2.11 Samlet nettoflytting i kommunene, fordelt etter kvantiler, slik at det er like mange kommuner i hver gruppe. 
Det er åpenbart at det har blitt færre røde og rosa kommuner i den siste perioden, samtidig som det har blitt langt flere blå. Det har blitt ganske få kommuner som har et samlet flyttetap i den siste perioden. Mange kommuner i distriktene har nå fått netto innflytting når innvandringen medregnes.

Et interessant spørsmål er om mønstrene er annerledes. Er det andre typer kommuner som nå får netto innflytting (inkludert innvandring)? Eller er mønstrene egentlig ganske like, bare med et positivt skift i nettoflyttingen som har løftet alle typer kommuner? Mønstrene vi ser, tyder på det siste. Det har konsekvenser for hvordan vi utformer modellen, som vi skal se i neste kapittel.

I kartene i figur 2.10 bruker vi de samme tallene som i kartene på forrige side, men nå har vi fordelt kommunene etter nettoflyttingen i forhold til hverandre i samme periode.

I kartene i figur 2.11 er kommunene fordelt etter kvantiler. Når vi ordner etter kvantiler er det like mange kommuner i hver gruppe. Her bruker vi fem kvantiler slik at en femtedel av kommunene er i hver gruppe. Det er altså like mange mørkeblå kommuner i hver av kartene.

Det er åpenbart at det sentraliserende flyttemønsteret har blitt opprettholdt. Vi ser at de mørkeblå kommunene, det vil si dem med høyest nettoflytting, fremdeles er lokalisert nær de største byene: Oslo, Kristiansand, Stavanger, Bergen og Trondheim.

Det kan kanskje se ut til at det er flere mørkeblå kommuner som ligger utenfor de store byregionene i den siste perioden. I den første perioden kan vi se at kommuner som Bø i Telemark, Fyresdal, Etne og Røros er mørkeblå. Det er de eneste typiske distriktskommunene som er mørkeblå i det første kartet (perioden 2000 til 2006).

I det andre kartet er Bø i Telemark fremdeles mørkeblå, sammen med andre typiske distriktskommuner som Flå, Hemsedal, Lyngdal, Austevoll, Sogndal, Ulstein, Ørskog, Hitra, Frøya, Træna og Gamvik. Det er dermed 12 typiske distriktskommuner blant de 85 kommunene med høyest nettoflytting i den siste perioden. Det kan dermed virke som at det sentraliserende flyttemønsteret i stor grad er det samme som før, men at den økte innvandringen har gjort at utviklingen er mindre forutsigelig for distriktskommunene. Det er fremdeles et flertall distriktskommuner blant dem med lavest nettoflytting, men det har blitt flere unntak.

I kartene i figur 2.12 er regionene fordelt etter kvantiler, slik at en femtedel av regionene er i hver gruppe. Det er altså like mange mørkeblå regioner i hver av kartene. 


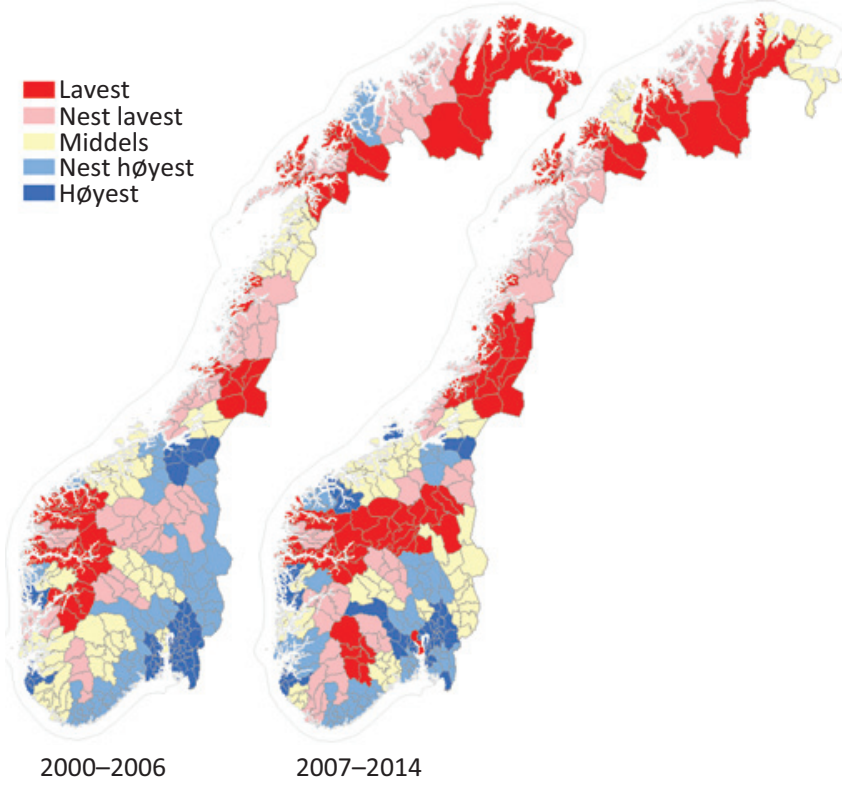

Figur 2.12 Samlet nettoflytting, fordelt etter kvantiler, slik at det er like mange regioner i hver gruppe.

Igjen ser vi at det sentraliserende flyttemønsteret har blitt opprettholdt. Vi ser at de mørkeblå regionene, det vil si dem med høyest nettoflytting, fremdeles er lokalisert nær de største byene: Oslo, Kristiansand, Stavanger, Bergen og Trondheim.

Det kan kanskje se ut til at det er flere mørkeblå regioner som ligger utenfor de store byregionene i den første perioden. I den første perioden kan vi se at regioner som Stjørdalsregionen, Trondheimsregionen, Stavangerregionen og regionene omkring Oslo og Bergen er mørkeblå.

I det andre kartet er Stjørdalsregionen, Stavangerregionen og regionene omkring Oslo og Bergen fremdeles mørkeblå, sammen med Storfjord, Ålesundsregionen, Nordhordland, Hitra/Frøya, Kongsberg/Numedal og Midt-Buskerud.

\subsubsection{Relativ nettoflytting}

Relativ nettoflytting er et begrep som skal beskrive nettoflyttingen til et sted i forhold til nettoflyttingen til landet. For norske regioner blir den relative nettoflyttingen lik regionens nettoflytting fratrukket Norges nettoflytting. Norges nettoflytting vil være landets netto innvandring. 


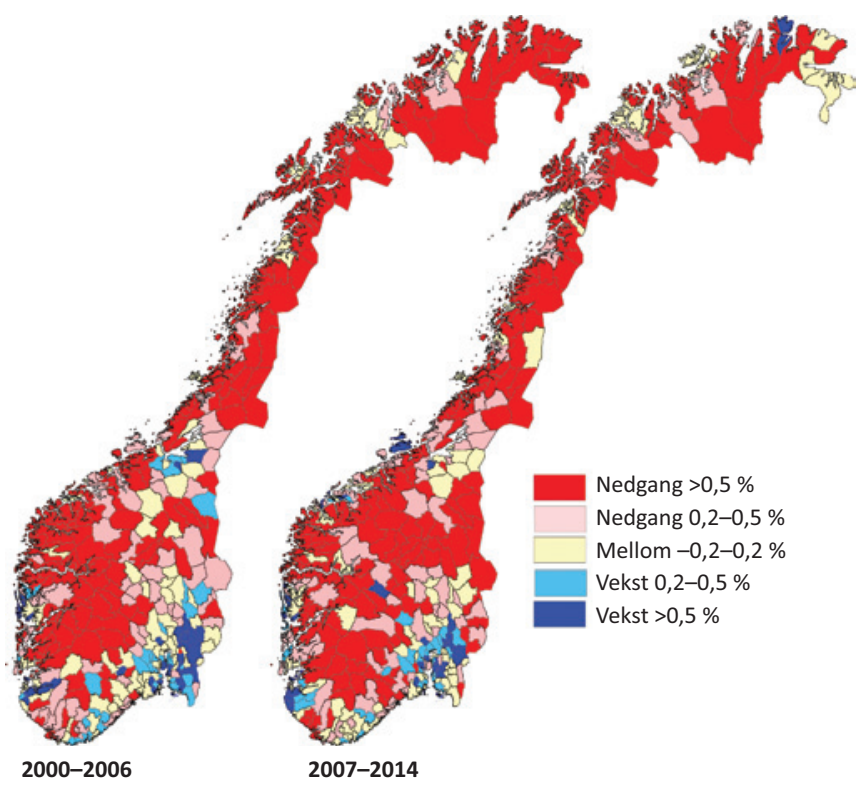

Figur 2.13 Relativ nettoflytting i kommunene.

Kartene over viser den relative nettoflyttingen i norske kommuner i to perioder. De røde er kommuner hvor nettoflyttingen er mer enn 0,5 prosent svakere per år enn landets nettoflytting. De rosa har også lavere nettoflytting enn landet, men da mellom 0,2 og 0,5 prosent mindre per år. Vi kan se at de fleste av landets kommuner har markant lavere nettoflytting enn landet. I den siste perioden hadde 108 av landets 428 kommuner en positiv relativ nettoflytting. I den første perioden var det 106 av kommunene som hadde positiv nettoflytting. De gule kommunene har en nettoflytting som er ganske lik landet, det vil si at nettoflyttingen ikke er mer enn 0,2 prosent forskjellig fra landets nettoflytting årlig.

De lyseblå og blå kommunene har markant bedre nettoflytting enn landet. De mørkeblå er kommuner med en relativ nettoflytting på over 0,5 prosent. Det var 36 slike kommuner i den første perioden, mens det var 37 slike kommuner i den andre perioden. I den første perioden var det bare Bø i Telemark av de mørkeblå som ikke er i pendlingsavstand til en større by. I den siste perioden har også distriktskommuner som Hemsedal, Hitra, Frøya, Ulstein og Gamvik blitt mørkeblå.

Vi vil fokusere på den relative nettoflyttingen (inkludert innvandring) når vi skal lage modellen. Problemstillingen blir da: Hva forklarer variasjonene i den relative nettoflyttingen mellom kommuner og regioner i Norge? 


\subsection{Arbeidsplassvekst}

Vi har så langt vist de regionale mønstrene i befolkningsvekst og fokusert spesielt på flyttemønstrene. I dette kapitlet skal vi gi en beskrivelse av arbeidsplassveksten i Norge og hvordan denne fordeler seg mellom kommuner og regioner i Norge. Det er spesielt flyttemønstre og arbeidsplassendringer vi ønsker å analysere og forstå.

Vi bruker begrepet arbeidsplasser om sysselsetting etter arbeidssted. Data henter vi fra registerbasert sysselsettingsstatistikk i SSB. I den registerbaserte sysselsettingsstatistikken skilles det mellom sysselsetting etter bosted og sysselsetting etter arbeidssted. Sysselsetting er dermed et flertydig begrep. Vi bruker derfor begrepet «sysselsetting» for sysselsetting etter bosted, mens vi bruker «arbeidsplasser» for sysselsetting etter arbeidssted.

I figur 2.14 ser vi at antall arbeidsplasser i Norge har økt med 17,2 prosent fra 2000 til slutten av 2014. Arbeidsplassveksten varierer over tid. I perioden 2005-2008 var arbeidsplassveksten spesielt høy. I denne perioden var det høykonjunktur i Norge, og vi ser at det var veksten i antall arbeidsplasser i næringslivet som trakk opp den samlede arbeidsplassveksten. Finanskrisen, som inntraff på slutten av 2008, førte til et fall i antall arbeidsplasser i næringslivet i 2009. Etter 2009 har det vært ganske jevn vekst i næringslivet. Vi kan

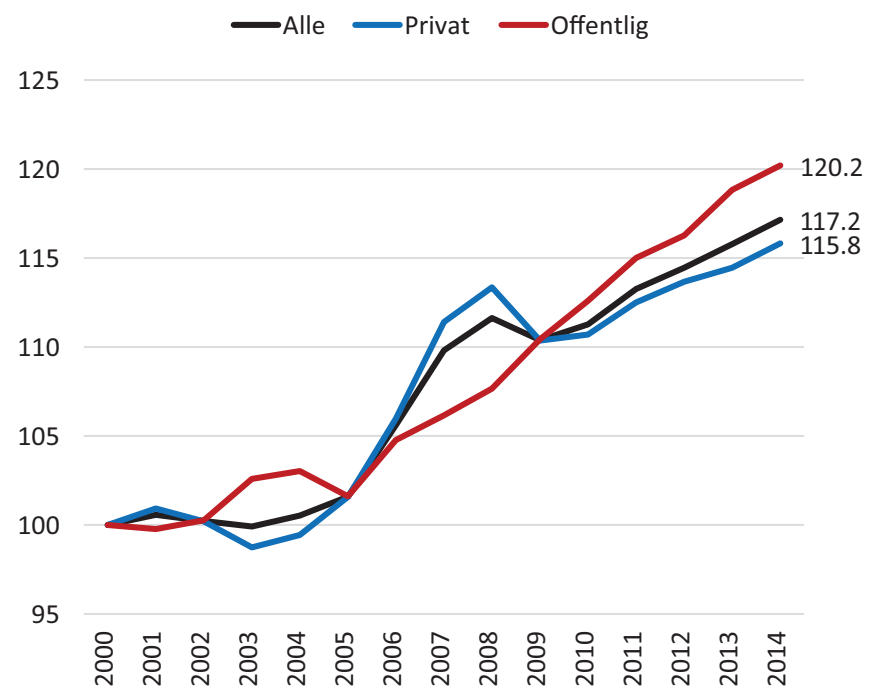

Figur 2.14 Utvikling i antall arbeidsplasser i Norge, indeksert slik at nivået i 2000 = 100 . 
også se at veksten i antall arbeidsplasser i det offentlige blir lite påvirket av konjunkturer. Den norske staten har store finansielle ressurser og kan derfor øke sine budsjetter i dårlige tider med såkalt motkonjunkturpolitikk. Det fører til at antall ansatte i det offentlige øker når det blir et fall i privat næringsliv.

\subsubsection{Vekst i næringslivet i ulike perioder}

Næringslivets vekst varierer sterkt over tid. I enkelte perioder er det såkalt høykonjunktur, og næringslivet vokser. Andre perioder er preget av kriser. Vi hadde dotcom-krisen rundt 2002-2003, finanskrisen som startet mot slutten av 2008, og til sist oljekrisen som startet mot slutten av 2014. Vi kan se disse høykonjunkturene og krisene tydelig på utviklingen av antall arbeidsplasser.

I perioden etter 2000 har det vært noen karakteristiske perioder med høykonjunktur og kriser. Perioden 2005-2008 var en høykonjunktur, da det var sterk vekst i antall arbeidsplasser i alle fylker i Norge. Finanskrisen rammet alle fylker, slik at samtlige fylker fikk nedgang i antall arbeidsplasser i næringslivet i 2009.

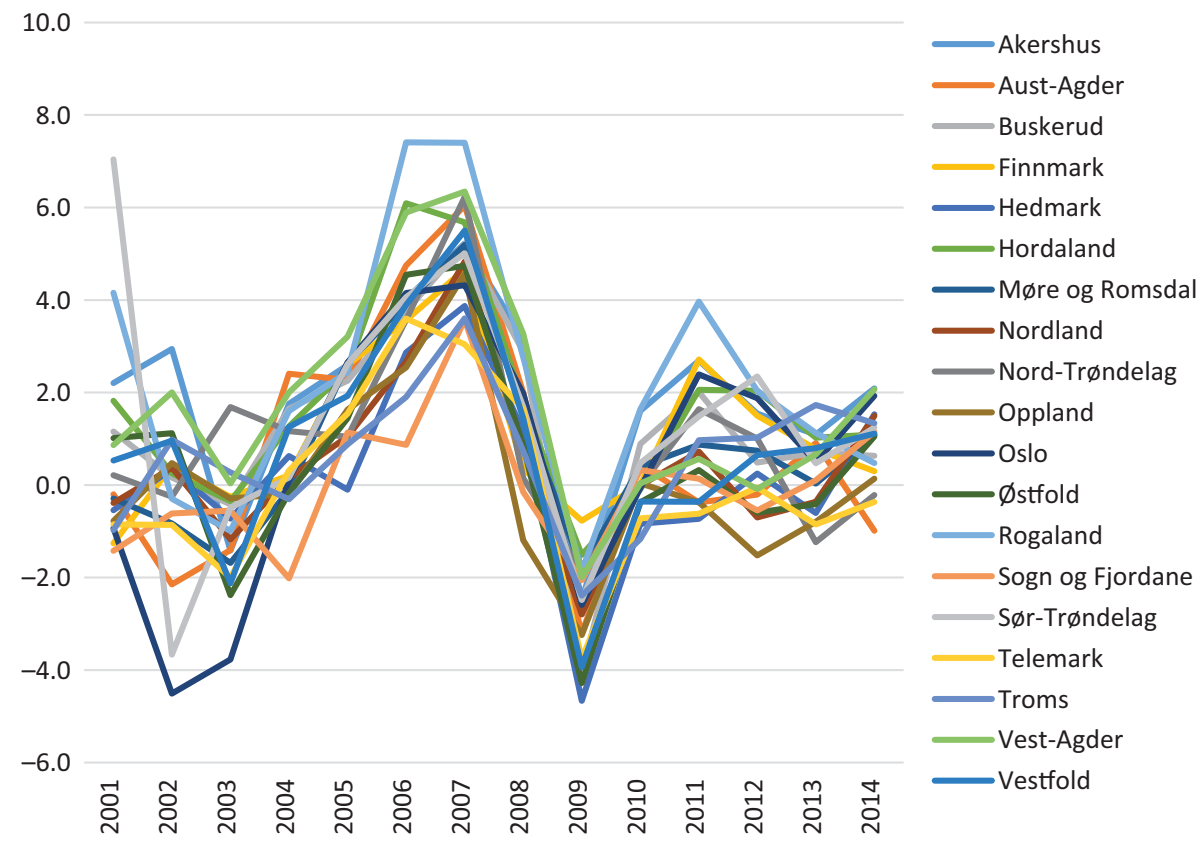

Figur 2.15 Prosentvis vekst i antall arbeidsplasser i næringslivet i årene 2000-2014, fylkesvis. 
I figur 2.15 ser vi at arbeidsplassveksten i næringslivet i de ulike fylkene i stor grad går i takt. Det betyr at det er nasjonale konjunkturer som påvirker veksten $\mathrm{i}$ alle deler av landet stort sett samtidig. Den såkalte dotcom-krisen i 2002-2003 rammet næringslivet i Oslo i langt større grad enn resten av landet. Det var fordi dette var en krise som hovedsakelig rammet IT-næringen. Siden IT-næringen var sterkt konsentrert i Oslo, ble denne krisen mest merkbar der. Høykonjunkturen mellom 2005 og 2008 var en generell oppgangstid for næringslivet over hele landet. Finanskrisen rammet også alle deler av landet. Oljekrisens virkninger har vi ikke sett de langsiktige virkninger av ennå. Men denne vil ramme de delene av landet hvor oljenæringene er mest konsentrert.

Konklusjonen er at næringslivet $i$ alle deler av landet blir påvirket av de nasjonale konjunkturene, men at stedenes bransjestruktur også er et forhold som har stor betydning.

\subsubsection{Regionale variasjoner i arbeidsplassvekst}

I våre analyser er det de regionale variasjonene som er i sentrum. I kartene under kan vi se variasjonen i arbeidsplassvekst mellom kommunene i Norge. Vi har beholdt de samme periodene som i foregående kapittel.

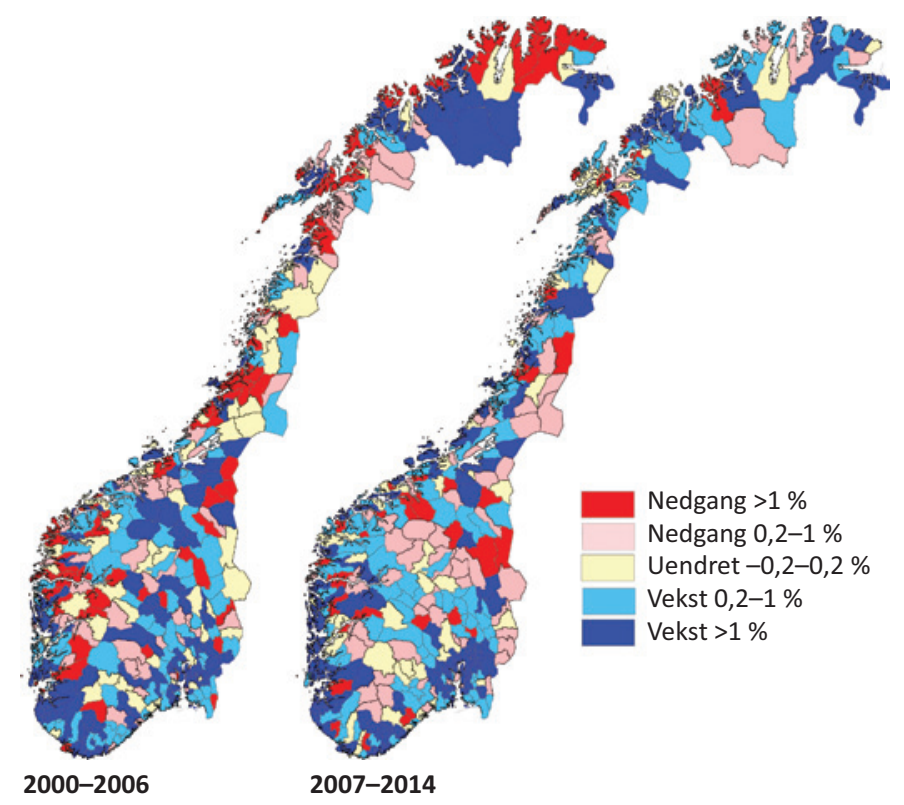

Figur 2.16 Arbeidsplassvekst i kommunene. 
Kartene i figur 2.16 som viser variasjonene i arbeidsplassvekst, viser ikke så klare mønstre som kartene over befolkningsvekst og nettoflytting. I kartet til høyre, som viser arbeidsplassveksten i den siste perioden, er det en viss klynge av kommuner med høy vekst rundt Oslo. I kartet til venstre er det en ganske klar klynge av vekstkommuner rundt Stavanger.

Det er dermed tilsynelatende langt mindre systematiske mønstre i arbeidsplassveksten enn i befolkningsveksten, i hvert fall langs dimensjonen sentralitet. Det er mange kommuner i perifere områder som har høy arbeidsplassvekst.

Når vi ser på arbeidsplassvekst i regionene, er det fremdeles ikke lett å se noen klare mønstre. Det er regioner med arbeidsplassvekst og arbeidsplassnedgang i alle landsdeler. Noen regioner har sterk arbeidsplassvekst i en periode, men arbeidsplassnedgang $i$ andre.

De regionale mønstrene i arbeidsplassveksten ser ut til å være langt mindre tydelige enn mønstrene i flyttingen. Det tolker vi som at det ikke er arbeidsplassveksten som er hovedårsaken til det sentraliserte flyttemønsteret vi så tidligere. Arbeidsplassveksten har nok bidratt til sentraliseringen til en viss grad, siden det er høyere arbeidsplassvekst i de mest sentrale regionene, men det er åpenbart at mange perifere regioner har hatt god arbeidsplassvekst.

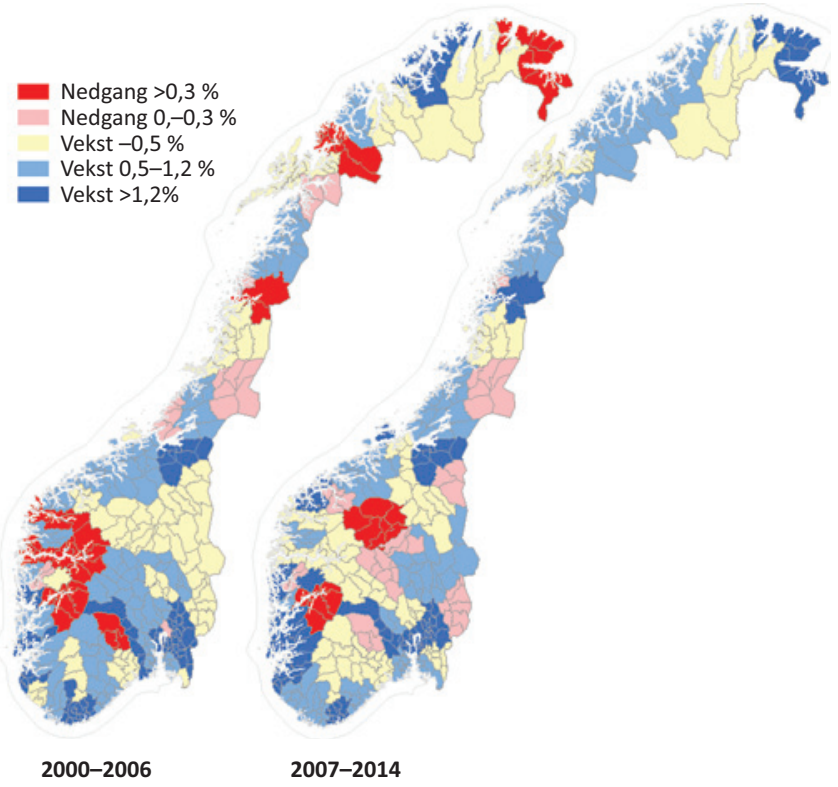

Figur 2.17 Arbeidsplassvekst i regionene. 
Sentraliseringen av befolkningen som vi ser av flyttemønstrene, synes å være langt kraftigere enn den sentraliseringen vi kan se av arbeidsplassene. Det betyr at det må være andre krefter enn arbeidsplassveksten som bidrar til sentraliseringen. Vi skal se nærmere på hva dette kan være, i neste kapittel.

\subsection{Hva de regionale vekstmønstrene betyr for modellen}

De vekstmønstrene vi har sett til nå i dette kapitlet, kan brukes til å spesifisere modellen mer nøyaktig enn vi så innledningsvis i figur 1.1.

De regionale utviklingstrekkene vi har beskrevet så langt i kapittel 2, har handlet om to forhold: endringen i antall arbeidsplasser og endringer i folketallet. Vi har så langt bare beskrevet den faktiske utviklingen, men i de neste kapitlene vil vi forsøke å skape en modell som kan forklare årsakene til den utviklingen vi har beskrevet. Vi har tatt noen valg som har avgjørende betydning for hvordan vi har utformet modellen. Vi skal kort gjøre rede for disse valgene før vi begynner å beskrive modellen.

\section{Næringsutvikling}

Arbeidsplasser finnes i både privat og offentlig sektor. Vi vil konsentrere oss om arbeidsplassendringene i det private næringslivet. Arbeidsplassendringene i offentlig sektor har naturligvis like stor betydning som i næringslivet, men det er endringene i næringslivet vi ønsker å analysere og forstå. Det betyr at

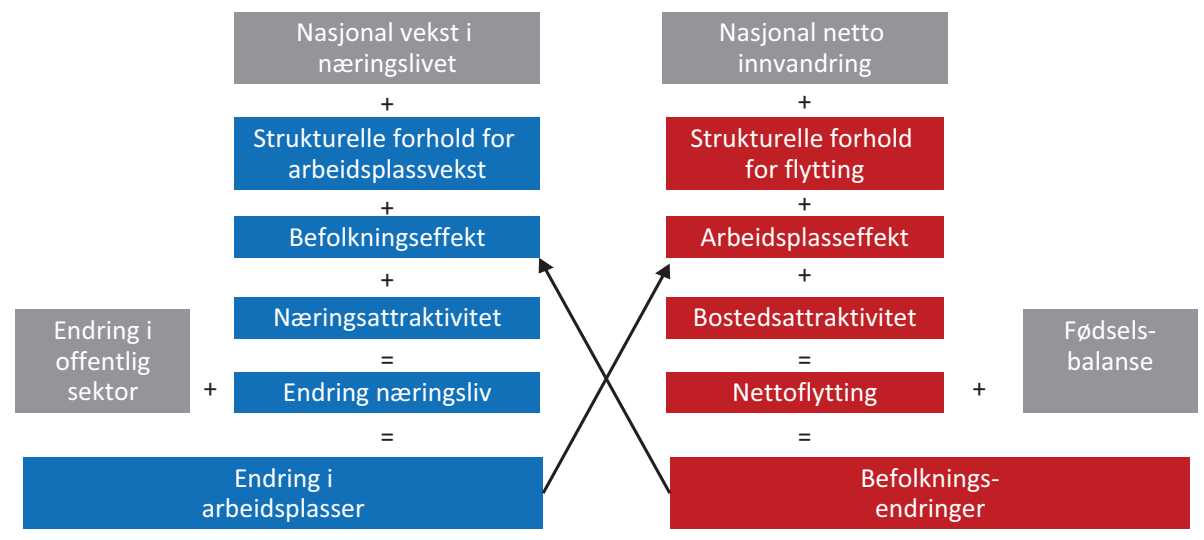

Figur 2.18 Logikk og struktur i attraktivitetsmodellen. 
endringene i antall arbeidsplasser i offentlig sektor er en størrelse som vi putter inn i modellen. Det er en eksogen faktor vi tar med, men modellen har ikke som ambisjon å forklare hvorfor offentlig sektor krymper eller vokser. Det er flere årsaker til at vi gjør dette valget. For det første er det som oftest næringsutviklingen som kommuner, regioner og fylker fokuserer på når de lager sine strategier for å øke veksten. Dermed er det næringsutviklingen det er behov for å forstå og påvirke. Antall arbeidsplasser i kommunal sektor er normalt en funksjon av de offentlige budsjettene. Ingen kommuner eller fylkeskommuner kan ansette flere enn de har inntekter til, i det minste ikke uten at det går utover antall arbeidsplasser i senere perioder. Statlige arbeidsplasser er imidlertid et tema for vekststrategier mange steder. Årsaken til lokaliseringen av statlige arbeidsplasser er imidlertid ikke egnet for den typen analyser vi skal gjøre her. Det enkle svaret på hvor statlige institusjoner er lokalisert, er at det blir bestemt av det offentlige.

\section{Flytting}

Når vi skal analysere befolkningsendringene, vil vi konsentrere oss om nettoflyttingen, mer spesifikt den relative nettoflyttingen. Det betyr at vi lar fødselsbalansen være en eksogen faktor. En av årsakene er at fødselsbalansen ikke er et tema for de regionale strategiene. Steder som ønsker å påvirke befolkningsveksten, er opptatt av å endre flyttebalansen, enten gjennom å trekke til seg flere innflyttere eller ved å redusere utvikling. Det er dermed nettoflyttingen som vi ønsker å analysere og forstå.

\section{Forklaringsfaktorer for vekst i næringslivet}

Endringene i antall arbeidsplasser i næringslivet antar vi er forårsaket av fire forhold:

For det første vil den nasjonale veksten, eller konjunkturene, påvirke veksten i alle områder av landet. Det betyr at under perioder med høykonjunktur vil alle områder få en vekstimpuls, mens i nedgangstider vil alle områder få en negativ impuls. Når vi skal forklare utviklingen i antall arbeidsplasser i næringslivet, vil den nasjonale veksten være lik for alle kommuner, regioner og fylker. Den kan ses på som en eksogen faktor som er lik for alle steder, men som vil variere alt etter hvilken tidsperiode vi analyserer.

For det andre vil det være noen strukturelle forhold som har ulik betydning for arbeidsplassveksten i næringslivet. I neste kapittel skal vi se hvilke 
strukturelle forhold som vi har funnet har en klar og systematisk sammenheng med næringslivsvekst.

For det tredje antar vi at stedets befolkningsvekst har en systematisk og positiv betydning for arbeidsplassveksten.

Den fjerde og siste forklaringsfaktoren er stedets næringsattraktivitet. Det vil da være den delen av næringslivsveksten som ikke skyldes konjunkturer, befolkningsvekst eller kjente strukturelle forhold. Det kan for eksempel være en næringslivsvekst som skyldes at det er ført en vellykket lokal næringspolitikk, eller at næringslivet er spesielt dyktig, innovativt og framgangsrikt.

\section{Forklaringsfaktorer for nettoflytting}

Nettoflyttingen antas å være et produkt av fire faktorer:

For det første antas den nasjonale nettoinnvandringen å påvirke alle steder på samme måte. Den blir en eksogen forklaringsfaktor på samme måte som den nasjonale veksten er en eksogen forklaringsfaktor for næringslivsutviklingen. Når den nasjonale innvandringen er høy, forventes det å påvirke alle steders nettoflytting på samme måte.

For det andre antar vi at det er strukturelle forhold som påvirker nettoflyttingen til steder. Vi skal i neste kapittel se hvilke strukturelle faktorer som vi har funnet empirisk belegg for.

For det tredje antar vi at veksten i antall arbeidsplasser også påvirker nettoflyttingen systematisk og positivt.

For det fjerde antar vi at steder har ulik bostedsattraktivitet. Bostedsattraktiviteten er da en faktor som gjør at stedet får en annen nettoflytting enn forventet ut fra den nasjonale nettoinnvandringen, strukturelle forhold eller arbeidsplassvekst. Bostedsattraktiviteten kan også være et resultat av lokal politikk, eller av andre stedsspesifikke forhold.

I det neste kapitlet skal vi vise hvordan attraktivitetsmodellen er utformet i detalj. Modellen er spesifisert gjennom empiriske analyser av statistiske data. Vi skal også løpende vise resultater og eksempler av analysene. 



\section{KAPITTEL 3}

\section{En modell for forventet vekst}

Vi ønsker å ha en modell som viser hvordan strukturelle forhold påvirker utviklingen på et sted. Strukturelle forhold er drivkrefter som påvirker utviklingen, men som er utenfor stedets kontroll. I utgangspunktet definerer vi alle årsaksforhold som ikke kan påvirkes lokalt eller regionalt, inn i de strukturelle drivkreftene. I løpet av en del år har vi lett og eksperimentert etter ulike strukturelle forhold som vi kan bygge inn i modellen. Forhold som har en klar og tydelig statistisk effekt på arbeidsplassvekst eller flytting, har vi beholdt og bygget inn i modellen. Forhold som vi har testet, men som ikke har tilstrekkelig tydelig effekt på arbeidsplassvekst eller flytting, har vi forkastet. I ettertid er det nesten forbausende hvor få elementer vi sitter igjen med. Nå skal vi først gjøre rede for hvordan vi lager en modell for forventet innflytting til et sted, og deretter forklare hvordan modellen for forventet arbeidsplassvekst i næringslivet ser ut.

\subsection{Drivkrefter for nettoflytting}

\subsubsection{Arbeidsplassvekstens effekt på flyttingen}

Flytter arbeidsplassene etter folk? Eller flytter folk etter arbeidsplassene? Det finnes ikke et enkelt svar på dette spørsmålet. Begge disse to mekanismene kan påvises. Det finnes eksempler på steder hvor arbeidsplassvekst er årsaken til innflytting og befolkningsvekst, og det finnes andre eksempler på steder der høy innflytting og befolkningsvekst har ført til vekst i antall arbeidsplasser. Vi skal senere se på hvilke typer arbeidsplasser som blir påvirket av befolkningsvekst, og hvilke typer som ikke blir påvirket.

Når vi skal se på forholdet mellom nettoflytting og arbeidsplassvekst, bruker vi variablene relativ nettoflytting og relativ arbeidsplassvekst. Årsaken er at dersom landets arbeidsplassvekst i en periode er for eksempel 5 prosent, 
vil vi forvente at en tilfeldig kommune med 5 prosents vekst ikke «vinner» innbyggere fra andre steder. Arbeidsplassveksten er jo den samme som ellers i landet. I en annen periode, da det ikke er arbeidsplassvekst i landet, vil en kommune med 5 prosent vekst $\mathrm{i}$ antall arbeidsplasser sannsynligvis trekke til seg innbyggere gjennom nettoflytting fordi arbeidsplassveksten er mye høyere enn de fleste andre steder.

\subsubsection{Sammenhengen mellom arbeidsplassvekst og nettoflytting}

Vi kan først se på sammenhengen mellom nettoflytting og arbeidsplassveksten i kommunene i Norge. Vi begynner med å se på perioden mellom 2000 og 2014 .

Figur 3.1 viser at det er en ganske sterk sammenheng mellom arbeidsplassvekst og nettoflytting i kommunene i Norge, i hvert fall over en periode på 15 år. Spørsmålet det er nærliggende å stille, er da hva som skaper denne sammenhengen. Er det arbeidsplassveksten som er årsaken til nettoflyttingen? Eller er det omvendt, at nettoflyttingen skaper arbeidsplassveksten? At arbeidsplassvekst i mange tilfeller har skapt netto innflytting til steder, er ganske åpenbart. Mange steder i Norge er befolket som et resultat av at det er skapt arbeidsplasser først. Det gjelder særlig steder som har hatt naturgitte forutsetninger for

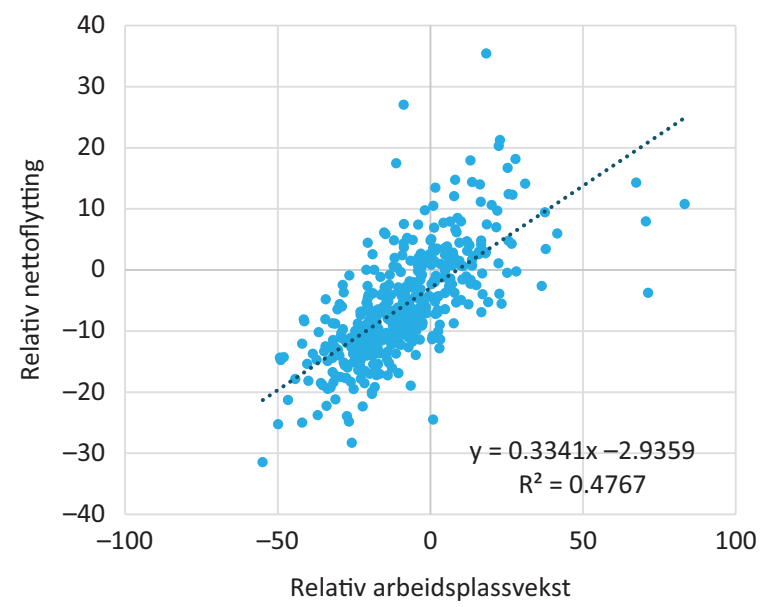

Figur 3.1 Kommunene i Norge, fordelt etter relativ arbeidsplassvekst og relativ nettoflytting i perioden 2000-2014. 
næringsliv, som industristeder som Årdal, Sunndal, Sauda, Odda, Rjukan og mange flere. På disse stedene er det ganske åpenbart at framveksten av de nye arbeidsplassene i industrien skapte innflytting og befolkningsvekst da industriproduksjonen ble bygget opp. På slike steder finner vi derfor at arbeidsplassveksten var en årsak til befolkningsveksten i disse periodene.

Det er også åpenbart at netto innflytting som skaper befolkningsvekst, også vil føre til arbeidsplassvekst. Steder som trekker til seg flere innbyggere, vil med stor sannsynlighet også få vekst i arbeidsplasser i næringer og sektorer som baserer seg på lokal etterspørsel, som barnehager, skoler, helsetjenester og handel.

Den sterke sammenhengen mellom arbeidsplassvekst og nettoflytting som vi fant i figuren 3.1, kan dermed ikke tolkes som at den ene faktoren forårsaker den andre. Hadde det vært et klart og entydig årsaksforhold, som at arbeidsplassveksten var årsak til nettoflyttingen, kunne vi sagt at 1 prosent vekst i relativ arbeidsplassvekst ville føre til o,3341 prosent ekstra nettoflytting (se formelen i diagrammet).

Årsaksforholdene er dessverre mer kompliserte. Arbeidsplassvekst og nettoflytting påvirker hverandre gjensidig. Arbeidsplassveksten påvirker nettoflyttingen positivt, samtidig som at nettoflyttingen også påvirker arbeidsplassveksten positivt.

Figuren er likevel interessant på flere måter. For det første kan vi se at sammenhengen mellom arbeidsplassvekst og nettoflytting ikke er veldig sterk, selv om den er ganske tydelig. Det er mange kommuner som har mye bedre nettoflytting enn arbeidsplassveksten skulle tilsi. Samtidig er det mange kommuner som ikke får positiv relativ nettoflytting selv om arbeidsplassveksten er sterk. Det betyr at dersom vi ønsker å forklare variasjonene i nettoflyttingen mellom kommunene, vil den relative arbeidsplassveksten være en faktor som forklarer noe, men det er tydeligvis flere andre faktorer som også påvirker nettoflyttingen til en kommune.

Vi kan også legge merke til at forventningslinjen ikke går gjennom origo, men krysser under. Formelen har et negativt konstantledd. Det betyr at dersom en kommune har samme arbeidsplassvekst som resten av landet (den relative arbeidsplassveksten er lik null) i hele perioden, så kan vi forvente at den relative nettoflyttingen er 2,9 prosent lavere enn ellers i landet. Det tolker vi som et utslag av sentraliseringen. De største byene får bedre nettoflytting enn de små. En middels kommune vil dermed normalt få noe lavere nettoflytting enn gjennomsnittet. 


\subsubsection{Hvordan sammenhengen endres med ulike tidsperioder}

Figur 3.1 som vi viste først i dette kapitlet, viser en ganske sterk og tydelig sammenheng mellom arbeidsplassvekst og nettoflytting. Da hadde vi brukt en forholdsvis lang periode, fra 2000 til 2015. Hvis vi bruker en kortere observasjonsperiode, blir sammenhengen svakere.

I figur 3.2, 3.3 og 3.4 ser vi hvordan sammenhengen mellom arbeidsplassvekst og nettoflytting har vært for norske kommuner i tre ulike tidsperioder. I figur 3.2 ser vi hvilken sammenheng det er når vi bruker ett år, i dette tilfellet 2014. Prikkene likner på en haglskur, selv om det er mulig å regne ut en viss positiv sammenheng. I figur 3.3 bruker vi en treårsperiode, hvor det går an å se en viss sammenheng. I figur 3.4 hvor observasjonsperioden er på sju år, er sammenhengen mer tydelig, selv om det fremdeles er ganske god spredning.

Dette fenomenet kan være et resultat av «støy». Jo kortere periode, desto større andel av verdiene vil være støy. Vi ser imidlertid at betaverdien øker. Denne verdien finner vi igjen i formlene i prikkdiagrammet, og er den verdien som multipliseres med $\mathrm{x}$ (arbeidsplassveksten). Når vi bruker ett års observasjonsperiode, ser vi at denne verdien er tilnærmet o,06. Det betyr at arbeidsplassveksten får en svært liten betydning for nettoflyttingen. Når vi bruker sjuårsperiode, er betaverdien tilnærmet 0,24. Effekten av arbeidsplassveksten er nå blitt fire ganger større.

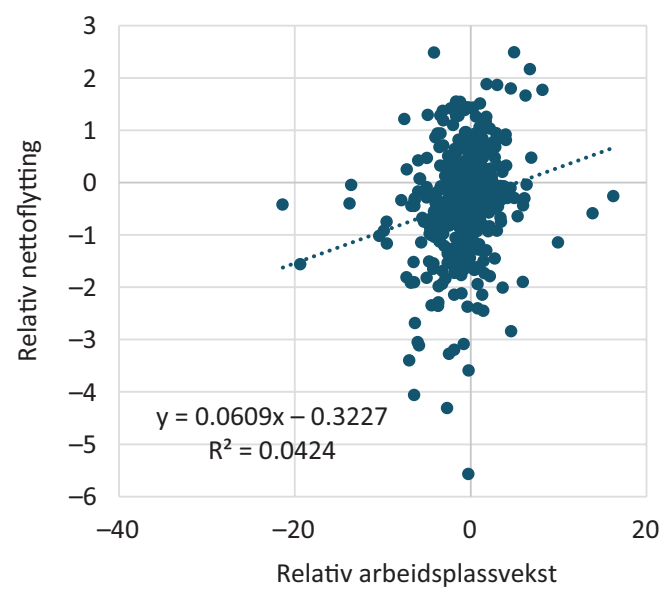

Figur 3.2 Relativ arbeidsplassvekst og relativ flytting i 2014. 


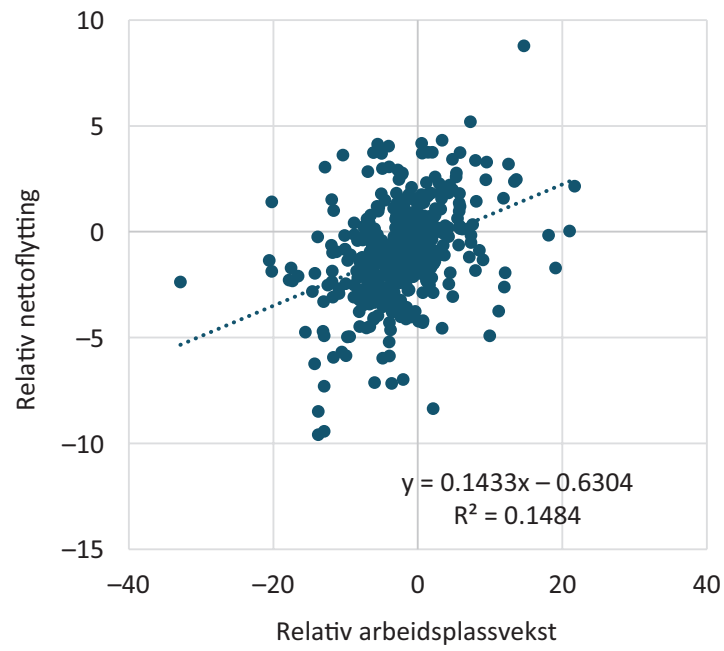

Figur 3.3 Relativ arbeidsplassvekst og relativ flytting i perioden 2012-2014.

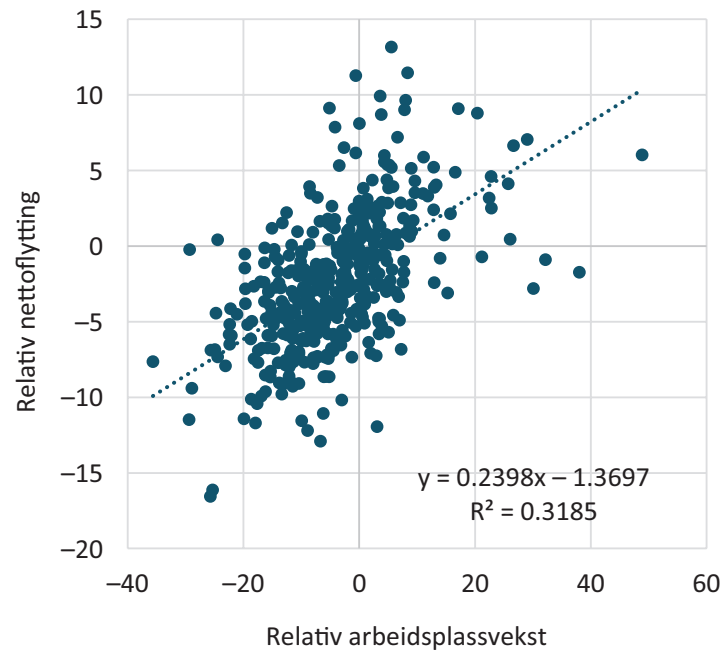

Figur 3.4 Relativ arbeidsplassvekst og relativ flytting i perioden 2008-2014.

Dette kan skyldes to forhold. For det første kan det være at arbeidsplassvekst i en periode har en positiv effekt på nettoflyttingen i neste periode. For det andre kan det være at nettoflyttingen i en periode påvirker arbeidsplassveksten i neste periode positivt. Begge hypotesene virker intuitivt tilforlatelige, men det er et metodisk problem at de representerer to motsatte årsaksforhold. 


\subsubsection{Hvordan sammenhengen endres med ulike geografiske inndelinger}

I figur 3.5, 3.6 og 3.7 ser vi hvordan sammenhengen mellom arbeidsplassvekst og nettoflytting har vært på forskjellige nivåer for norske kommuner, fylker og regioner. I figur 3.5 ser vi hvilken sammenheng det er når vi bruker kommunenivået. I figur 3.7 bruker vi fylkesnivået. I figur 3.6 regionnivået.

Sammenhengen mellom arbeidsplassvekst og flytting blir større når vi bruker regioninndeling, enn når vi bruker kommuner. Betaverdien nærmer

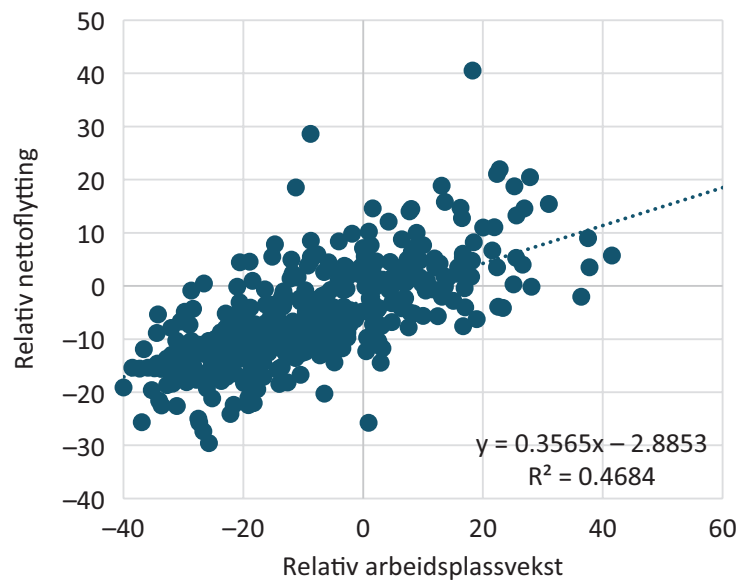

Figur 3.5 Relativ arbeidsplassvekst og relativ flytting i kommunene i perioden 2000-2014.

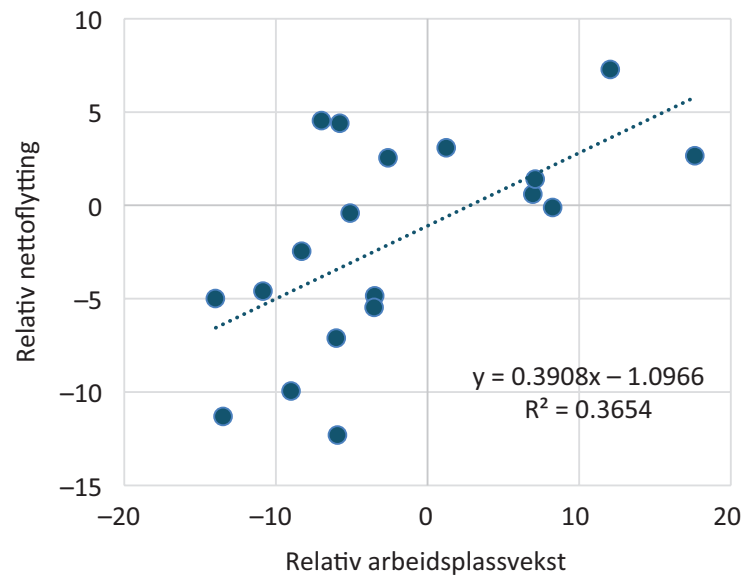

Figur 3.6 Relativ arbeidsplassvekst og relativ flytting i fylkene, 2000-2014. 


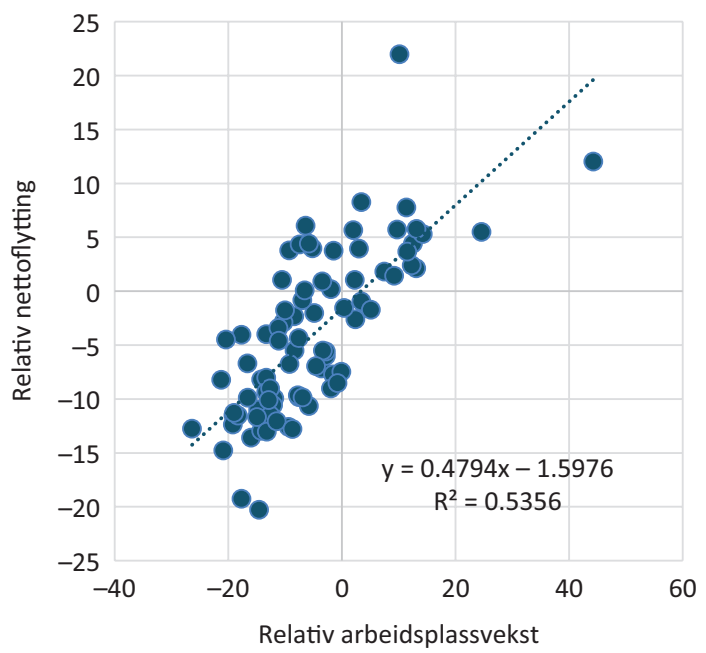

Figur 3.7 Relativ arbeidsplassvekst og relativ flytting i regionene, 2000-2014.

seg 0,48 på regionnivået sett over en 14 års tidsperiode. Den er noe mindre på fylkesnivå og minst på kommunenivå over samme tidsperiode.

Regionnivået er det som ligner mest på funksjonelle arbeidsmarkeder. Vi bruker en regioninndeling som vi kaller politiske regioner. Kommuner som inngår i interkommunalt samarbeid i form av regionråd eller interkommunale næringsselskaper, er da gruppert sammen. Fylkeskommunene har som oftest gruppert kommunene i fylket i regioner etter samme prinsipp. Denne regioninndelingen er ikke helt den samme som en får dersom en går teknisk til verks og grupperer kommuner etter faktisk pendling, men den er heller ikke veldig forskjellig.

Når vi får svakere sammenheng mellom arbeidsplassvekst og flytting på kommunenivå, kan det henge sammen med at en del av effekten av arbeidsplassveksten vannes ut gjennom pendling. Det gjelder spesielt kommuner som har mye pendling ut og inn. Det må vi ta hensyn til.

\subsubsection{Arbeidsplassvekst og pendling - egenvekst og nabovekst}

Så langt har vi sett på sammenhengen mellom arbeidsplassvekst og nettoflytting, i ulike tidsperioder og med ulik geografisk inndeling. Da har vi ikke tatt med at en ganske stor andel av befolkningen pendler, det vil si at de bor i én 
kommune og arbeider i en annen. Det er et kompliserende element, men må tas med, ettersom det har stor betydning. Vi kan illustrere hvordan pendlingen får betydning for sammenhengen mellom arbeidsplassvekst og nettoflytting, med å bruke to klare eksempler fra norske kommuner: Rælingen og Lørenskog.

\subsubsection{Rælingeneffekten: nettopendling}

Mot slutten av 2013 var det 2917 arbeidsplasser i Rælingen. Det bodde imidlertid hele 9034 personer i Rælingen som hadde jobb. Rælingen er den kommunen i Norge med størst netto utpendling. Det gjør at dersom antall arbeidsplasser i Rælingen øker med 10 prosent, blir det omtrent 292 flere arbeidsplasser. Det gjør at en vekst på 10 prosent i antall arbeidsplasser i Rælingen ikke får samme betydning som en tilsvarende prosentvis økning ville fått i en annen kommune. Det kan vi kompensere for gjennom å se på arbeidsplassveksten korrigert for nettopendling. For Rælingens vedkommende betyr det at vi justerer arbeidsplassveksten med nettopendlingen.

Det kan vi gjøre gjennom å multiplisere veksten med nettopendlingen, der nettopendlingen er:

$$
=\frac{\text { Arbeidsplasserikommunen }}{\text { Sysselsettingenikommunen }}
$$

\subsubsection{Lørenskogeffekten: arbeidsmarkedsintegrasjon}

Den andre effekten kan vi kalle Lørenskogeffekten. Lørenskog er den kommunen som har høyest andel pendlere inn og ut av kommunen. 67,9 prosent av dem som hadde jobb i Lørenskog på slutten av 2014, pendlet til en annen kommune, mens det ble pendlet inn til 70,7 prosent av jobbene i Lørenskog. Dersom antall arbeidsplasser i Lørenskog øker med 100, vil det dermed være sannsynlig at det i bare 29,3 prosent av disse jobbene blir ansatt en lørenskoging. Arbeidsplassvekstens effekt på bosettingen blir dermed spredt til alle de kommunene som har pendling til Lørenskog. I motsatt ende av skalaen finner vi kommuner som Træna, Røst og Værøy, hvor det er lite eller ingen dagpendling. I slike kommuner vil en vekst på 100 arbeidsplasser bety en vekst på nær 100 ekstra sysselsatte personer i kommunen. Arbeidsplassvekstens effekt på nettoflyttingen blir dermed sterkere i kommuner med lite eller ingen pendling, enn i kommuner med stor pendling. 
Dette kan korrigeres for gjennom å multiplisere arbeidsplassveksten med den andelen av sysselsettingen som arbeider i egen kommune. Formelen vil være:

$$
=\frac{\text { Sysselsetting }- \text { Innpendling }}{\text { Sysselsetting }}
$$

Effekten av arbeidsplassvekst i egen kommune vil måtte korrigeres for begge disse effektene. Hvis vi multipliserer begge disse effektene og forenkler litt, vil den variabelen som påvirker nettoflyttingen, bli:

$$
=\frac{\text { Arbeidsplassvekst } \times(\text { Arbeidsplasser }- \text { Innpendling })}{\text { Sysselsettingen }}
$$

Det leddet som arbeidsplassveksten skal multipliseres med, er det samme som andelen av de sysselsatte i kommunen som arbeider i egen kommune. Det betyr at dersom en liten andel av de sysselsatte arbeider i egen kommune, blir arbeidsplassvekstens effekt på nettoflyttingen lavere enn dersom det er en høy andel som arbeider i egen kommune. Senere vil vi referere til denne verdien som «egenvekst».

\subsubsection{Lekkasje}

Som vi så på forrige side, vil en del av effekten som arbeidsplassvekst har på nettoflyttingen, «lekke» ut til andre kommuner. Hensikten med den siste formelen er å korrigere for denne lekkasjen. Lekkasjeeffekten blir ulik for kommunene, og det kan være interessant å se hvilke kommuner som har størst og lavest lekkasje.

Lekkasjeeffekten vil være lik andelen av sysselsettingen som arbeider i egen kommune.

I figur 3.8 ser vi de ti kommunene med høyest lekkasjeeffekt. Faktoren på 0,16 for Rælingen betyr at den prosentvise relative arbeidsplassveksten i Rælingen skal multipliseres med 0,16 når vi beregner hvilken effekt arbeidsplassveksten vil ha for nettoflyttingen i kommunen. 84 prosent av dem som har jobb i Rælingen, arbeider i andre kommuner, slik at det er arbeidsplassveksten i de andre kommunene (som Oslo og Skedsmo) som betyr mest for bosettingen i Rælingen. En kommune som Rælingen må dermed ha en svært sterk endring $\mathrm{i}$ antall arbeidsplasser $\mathrm{i}$ egen kommune for at det 
skal få nevneverdig effekt på nettoflyttingen til kommunen. Vi kan se at de ti kommunene med størst lekkasjeeffekt er små kommuner som ligger tett opp til Oslo eller Trondheim.

I figur 3.9 vises de ti kommunene med minst lekkasjeeffekt. Det er alle kommuner i Nord-Norge. Det er kommuner hvor nesten alle som har jobb, arbeider i egen kommune. I slike kommuner vil arbeidsplassendringer få en direkte effekt på nettoflyttingen.

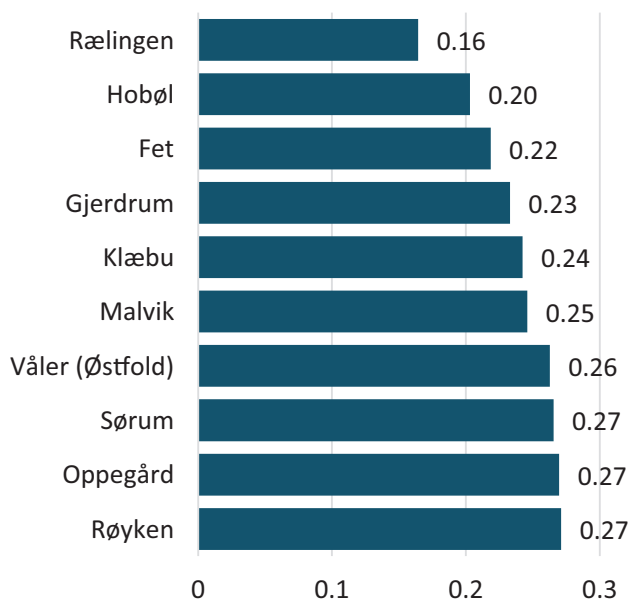

Figur 3.8 Kommuner med høyest lekkasjeeffekt i 2014.

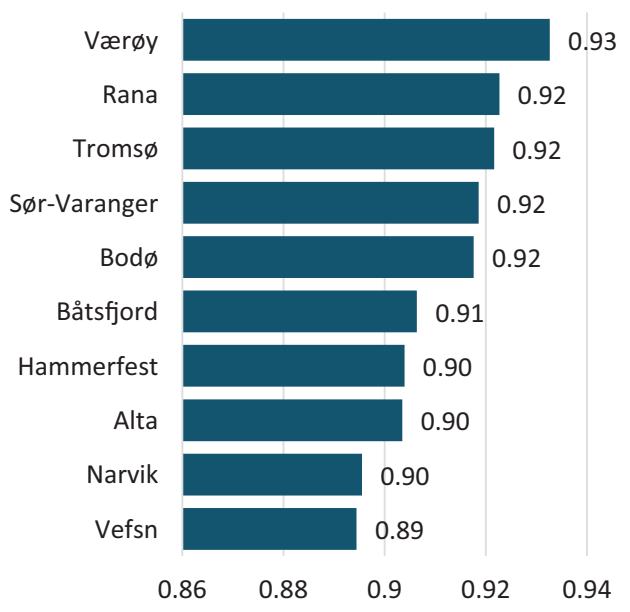

Figur 3.9 Kommuner med lavest lekkasjeeffekt i 2014. 


\subsubsection{En modell for hvilken effekt arbeidsplassveksten har på flytting}

Vi skal ta opp tråden vi var inne på i kapittel 3.1.3. I det kapitlet så vi at sammenhengen mellom nettoflytting og arbeidsplassvekst blir svakere dess kortere tidsperiode vi velger. Vi kunne brukt en lang tidsperiode, men da er det for det første fare for at vi overvurderer arbeidsplassvekstens betydning for nettoflyttingen, fordi sammenhengen antakelig forsterkes på grunn av det motsatte kausale forholdet, nemlig at nettoflyttingen også påvirker arbeidsplassveksten. For det andre vil det å bruke lange observasjonsperioder gjøre at vi går glipp av variasjoner innenfor perioden. Ofte ønsker vi å si noe om utviklingen det siste året, og det kan vi ikke gjøre dersom vi bruker tidsperioder på for eksempel fem eller ti år. Tidligere brukte Telemarksforsking observasjonsperioder på tre år, som et kompromiss.

Den løsningen vi har valgt, er å ha som hypotese at nettoflyttingen i et bestemt år påvirkes av arbeidsplassveksten i det samme året, men også arbeidsplassveksten i de foregående årene. Dette kan uttrykkes med formelen:

$$
\begin{aligned}
& \text { Nettoflytting år } i=b_{0}+b_{1} \times \text { Arbeidsplassvekst å } i+\mathrm{b}_{2} \\
& \times \text { Arbeidsplassvekst år } i_{-1}+\text { osv. }
\end{aligned}
$$

Det er naturlig å tenke seg at effekten av arbeidsplassveksten avtar etter som vi går lenger og lenger tilbake i tid.

Neste trinn er å finne verdiene på betaverdiene ut fra historiske data. Her har vi lagt inn verdiene for arbeidsplassvekst og flytting og kjørt en regresjonsanalyse for kommunene for enkeltårene 2003 til 2015, og til slutt for alle årene samlet.

Den første linjen viser at det er negativt intercept for alle seriene. Det betyr at en kommune med gjennomsnittlig arbeidsplassvekst er forventet å ha negativ relativ nettoflytting. Det er på grunn av at de største kommunene vinner innflyttere på bekostning av små, uavhengig av arbeidsplassveksten.

Betaverdiene for egenvekst varierer fra år til år. Betaverdien angir hvor stor ekstra innflytting (i prosent av folketallet) som en enhets økning i egenveksten medfører. Vi har forklart tidligere hvordan vi har beregnet verdien for egenvekst. For å repetere: Egenveksten er den samme som den prosentvise arbeidsplassveksten $\mathrm{i}$ en kommune som ikke har noe pendling ut og inn av kommunen. 
KAPITTEL 3

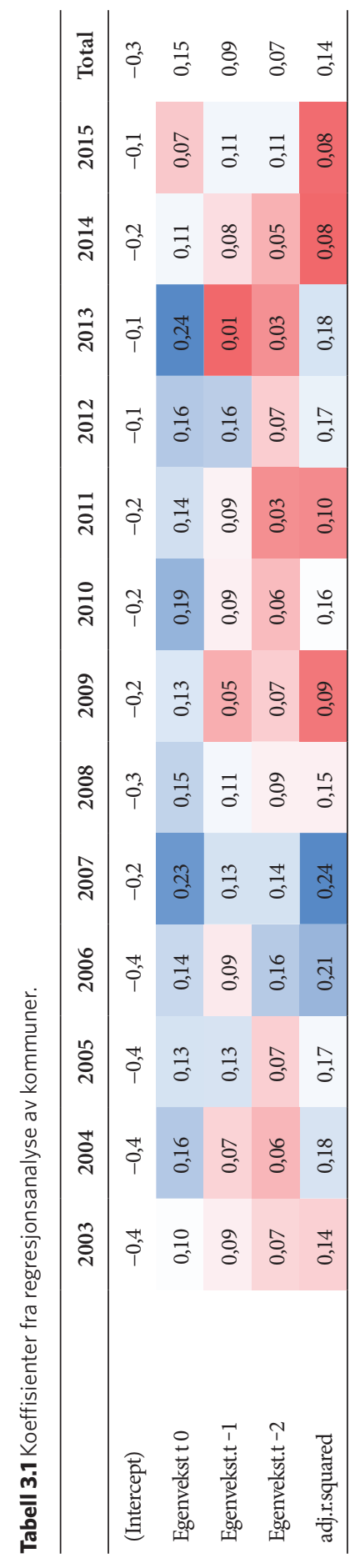




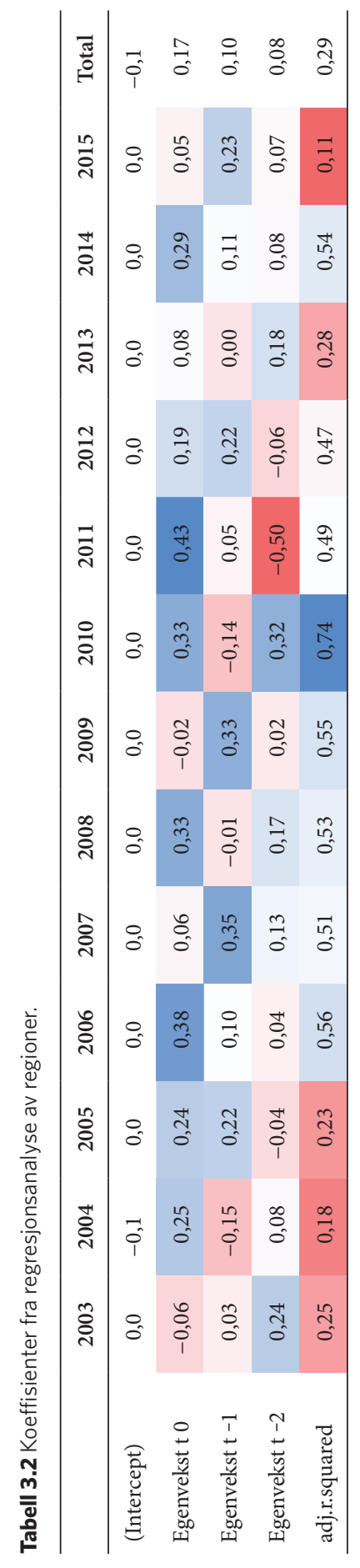


For kommuner med mye inn- og utpendling blir verdien lavere fordi effekten av arbeidsplassveksten blir utvannet.

Vi har begrenset oss til å bruke egenveksten i tre år. Det vil si at vi har neglisjert effekten som arbeidsplassveksten har på flyttingen fire eller flere år etter.

Som ventet er det egenveksten i samme år som har størst effekt på nettoflyttingen. I årene 2013 og 2007 fikk vi betaverdier på 0,24 og 0,23. Det betyr at en egenvekst på 1 vil føre til ekstra innflytting tilsvarende 0,24 prosent av folketallet. I andre år er betaverdiene langt lavere. I 2015 var betaverdien bare 0,07.

Den siste linjen (adjusted $\mathrm{r}$ squared) er et mål for hvor mye arbeidsplassveksten i de tre årene forklarer av nettoflyttingen. I 2007 var verdien på det høyeste 0,24. I dette året forklarte arbeidsplassveksten ganske mye av nettoflyttingen. I 2009, 2014 og 2015 var verdien lavere. Det kan virke som at arbeidsplassveksten forklarer mer av flyttingen i perioder med jevn vekst. I 2005-2008 var det generelt sterk vekst i Norge. Det samme var det i perioden 2010-2013. I 2009 var det arbeidsplassnedgang etter finanskrisen. Da ser vi at arbeidsplassveksten forklarte forholdsvis lite. Etter oljekrisen i 2014 får vi igjen en periode der arbeidsplassveksten forklarte mindre av flytting. Det kan se ut til at sammenhengen mellom arbeidsplassvekst og nettoflytting er sterkere i oppgangstider enn i krisetider.

Den siste kolonnen viser hvilke betaverdier vi får når vi bruker alle årene i samme regresjon. Disse verdiene vil vi bruke aktivt for å beregne arbeidsplasseffekten på nettoflytting.

Forventet nettoflytting $\mathrm{i}$ en kommune vil da være egenveksten samme år * $0,15+$ egenvekst ett år tidligere ${ }^{\star} 0,09+$ egenvekst to år tidligere ${ }^{\star} 0,07$.

Vi ønsker også å beregne betaverdiene for regioner med samme metode. Resultatene vises i tabell 3.2. Når vi kjører regresjonsanalysen for regioner i stedet for kommuner, blir sammenhengen mellom arbeidsplassvekst og nettoflytting sterkere. Som nevnt antar vi at det skyldes at regioninndelingen vi bruker, ligger tett opp til de funksjonelle arbeidsmarkedene.

Igjen ser vi at betaverdien for egenvekst samme år er svært lav i kriseårene 2009 og 2015, og til og med negativ i 2009. Egenveksten for 2009 har også negativ betaverdi for nettoflytting i 2010 og 2011. Forklaringskraften samlet sett er spesielt lav for 2015. Sysselsettingstallene for 2015 er usikre, ettersom SSB skiftet metode for telling av sysselsatte i 2015. 
På samme måte som for kommunene, vil vi bruke betaverdiene som kom fram, når vi bruker data fra alle årene. De er henholdsvis 0,17 for år t, o,10 for t- 1 og 0,08 for $\mathrm{t}$ - 2. Det er litt høyere verdier enn vi fikk i kommuneanalysen.

\subsubsection{Sammenhengen mellom arbeidsplassvekst og nettoflytting over tid}

I figur 3.10 ser vi sammenhengen mellom nettoflyttingen i kommunene i 2014, og forventet nettoflytting basert på arbeidsplassveksten i egen kommune de siste tre årene. For å regne ut forventet nettoflytting bruker vi verdiene på forrige side, slik at forventet nettoflytting er lik arbeidsplassvekst i $2014^{\star} 0,15+$ arbeidsplassvekst i $2013^{\star} 0,08+$ arbeidsplassvekst i $2012{ }^{\star} 0,07$.

Som vi kan se, er sammenhengen ganske svak. $\mathrm{R}^{2}$ er 0,08. Det er imidlertid en bedre sammenheng enn vi fikk tidligere, da vi bare så på sammenhengen mellom arbeidsplassvekst i nettoflytting i enkeltåret 2014. $\mathrm{R}^{2}$ blir av og til tolket i retning av hvor stor forklaringskraft modellen har - i dette tilfellet at arbeidsplassveksten i årene 2012-2014 forklarer åtte prosent av variasjonen $\mathrm{i}$ nettoflyttingen, og at andre faktorer forklarer de resterende 92 prosentene. I dette tilfellet er det sannsynlig at variasjonen i nettoflytting

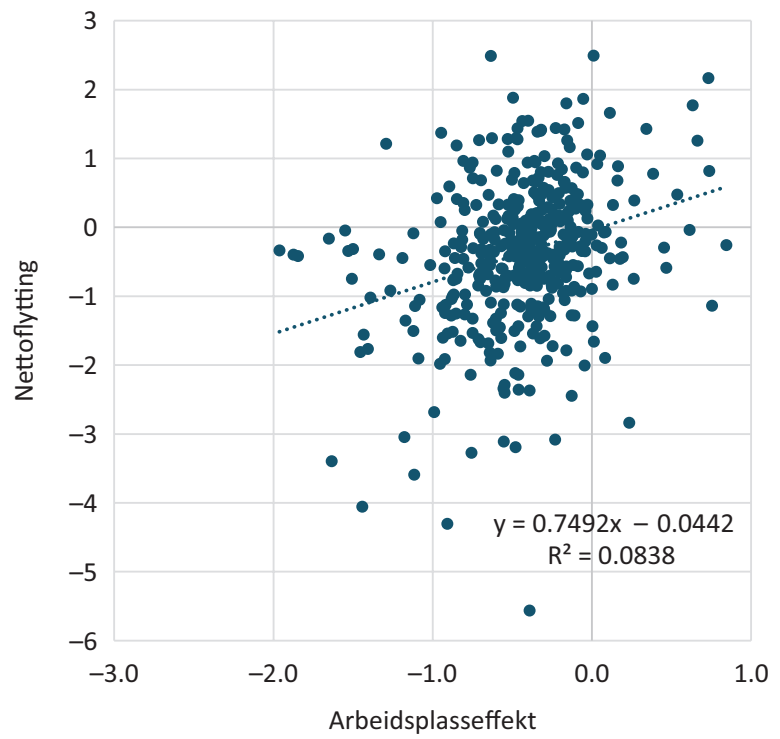

Figur 3.10 Relativ nettoflytting i kommunene i 2014 og forventet nettoflytting basert på arbeidsplassveksten siste tre år. 
forsterkes av tilfeldigheter, støy og målefeil (statistikken er ikke alltid nøyaktig, særlig ikke arbeidsplassveksten).

Hvis vi bruker en observasjonsperiode på sju år, som i figur 3.11, blir sammenhengen mellom arbeidsplassvekst i nettoflytting langt mer tydelig. $\mathrm{R}^{2}$ har nå økt til o,36.

I en så lang observasjonsperiode vil vi imidlertid få med to prinsipielt ulike effekter. Vi får med arbeidsplassvekstens effekt på nettoflyttingen, men vi får samtidig med nettoflyttingens effekt på arbeidsplassveksten. Steder med netto innflytting vil få økt befolkningsvekst. Befolkningens størrelse påvirker etterspørselen i området. Dermed vil steder med høy netto innflytting få en positiv etterspørselsimpuls som gjør at arbeidsplassveksten blir sterkere. Det gjør at vi får en sterkere sammenheng mellom arbeidsplassvekst og nettoflytting dess lengre periode vi ser på.

\subsubsection{Brutto bostedsattraktivitet}

Arbeidsplassveksten forklarer bare deler av nettoflyttingen. Hvis vi ser på avviket mellom forventet nettoflytting basert på arbeidsplassveksten de siste tre år og faktisk nettoflytting, får vi fram mønstre som vist i kartene i figur 3.12.

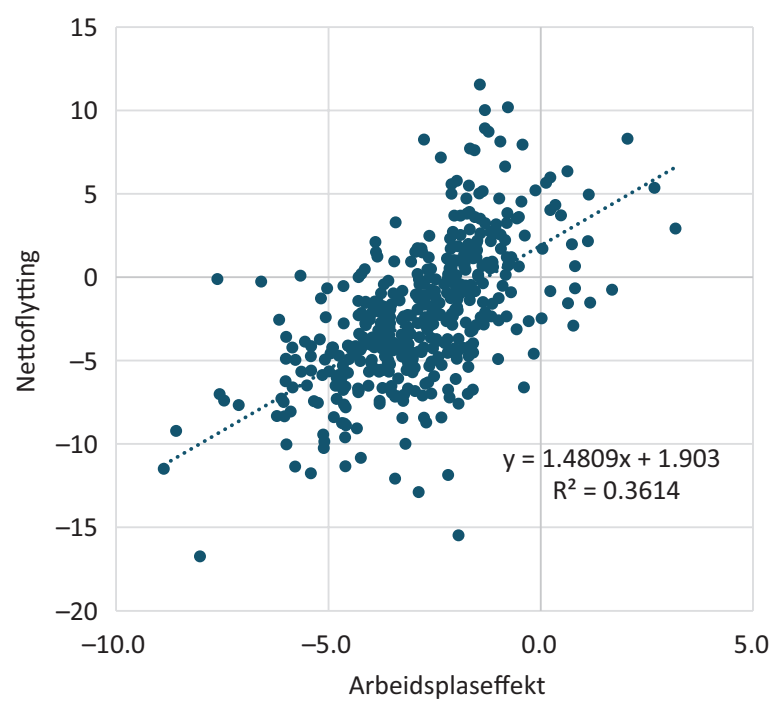

Figur 3.11 Relativ nettoflytting i kommunene i 2008-2014 og forventet nettoflytting basert på arbeidsplassveksten siste tre år. 


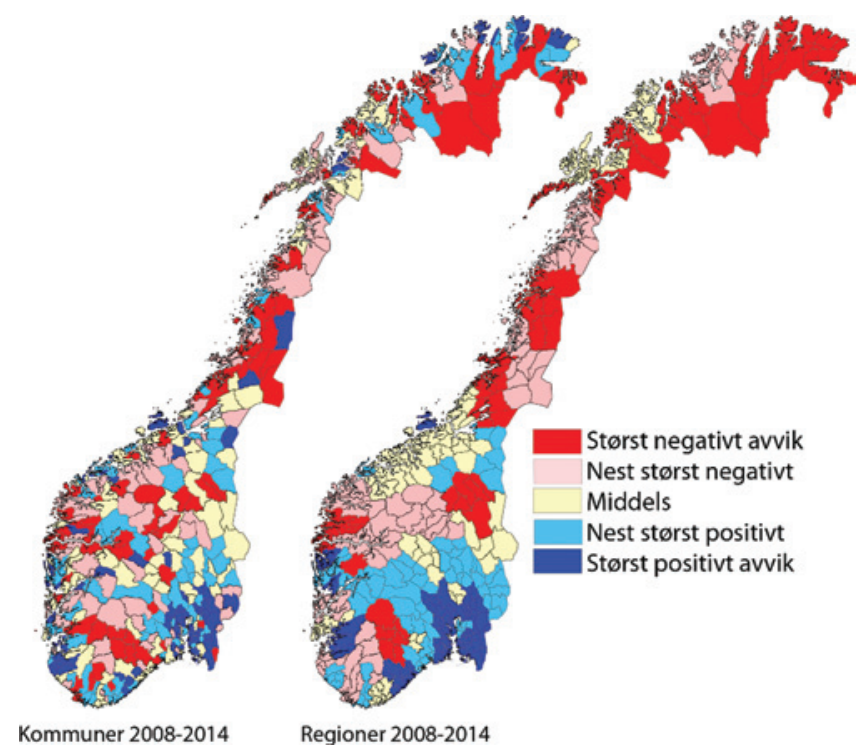

Figur 3.12 Avvik mellom faktisk flytting og forventet flytting ut fra arbeidsplassvekst i eget område. Også kalt brutto bostedsattraktivitet.

I kartene i figur 3.12 har vi vist hvilke kommuner og regioner som har mye eller lite nettoflytting ut fra arbeidsplassveksten i eget område. Det er lettest å se mønstrene i regionkartet. Det er mye uforklart innflytting til det sentrale Østlandsområdet. Rundt Bergen er det også mye innflytting som ikke forklares av arbeidsplassveksten. I tillegg har Østre Agder og Ryfylke overraskende mye innflytting. Det er regioner som grenser til henholdsvis Kristiansand og Stavanger, og som har mye pendling til disse byene. Hitra/Frøya har også mye uforklart innflytting, men det er en helt spesiell region vi skal komme tilbake til senere. Felles for de områdene som har mye mer innflytting enn forventet ut fra arbeidsplassveksten, er at de enten har en høy befolkningstetthet (mange innbyggere) eller ligger inntil eller inni store arbeidsmarkeder som de kan pendle til. Mønsteret er at det er stor innflytting til kommuner og regioner som enten har mange innbyggere, eller som har stor ut- og innpendling. Det er tilsvarende mindre nettoflytting i kommuner og regioner som har lavt innbyggertall, og som har lite pendling ut fra og inn til området.

Dette tolker vi som at befolkningen har bostedspreferanse til områder som ligger i store arbeidsmarkeder. Forklaringen kan være at slike steder gir større valgmuligheter for arbeid. Dette er en av de kraftigste drivkreftene for sentraliseringen. 


\subsubsection{Strukturelle drivkrefter for flytting}

Vi har sett at arbeidsplassveksten har en klar og systematisk effekt på steders nettoflytting. Det er ikke uventet. Samtidig ser vi at det er noen klare regionale mønstre i nettoflyttingen også når det gjelder det vi kaller brutto bostedsattraktivitet. Noen sentrale områder trekker til seg innflytting i større grad enn arbeidsplassveksten tilsier. Det er altså tydelig at det er noen andre egenskaper enn arbeidsplassvekst som påvirker nettoflyttingen.

\subsubsection{Nabovekst}

Eksemplene viser at arbeidsplassvekst i egen kommune ikke bare skaper økt sysselsetting i egen kommune, det skaper også økt sysselsetting i kommuner som har utpendling til denne kommunen. Disse kommunene får da økt sysselsetting som følge av at nabokommunen har arbeidsplassvekst. Dette kan da tenkes å føre til økt nettoflytting på samme måte som arbeidsplassvekst i egen kommune. Vi kan lage en variabel for nabovekst ved å se på arbeidsplassveksten i alle kommuner som det pendles ut til, vektet med andelen som pendler til hver enkelt kommune.

For kommuner med lite eller ingen pendling, for eksempel Træna, vil naboveksten bety lite eller ingenting, fordi det er svært små andeler som pendler ut. Vektingen med pendlingsandelen vil dermed redusere naboveksten til nær null. For kommuner med stor utpendling vil naboveksten kunne få en betydelig effekt. Effekten av naboveksten i kommuner med mye utpendling kan bli både positiv og negativ, avhengig av om nabokommunene har vekst eller nedgang. Kommuner med høy arbeidsmarkedsintegrasjon vil også kunne ha nabovekst nær null, dersom nabokommunene har samme vekst som ellers i landet, eller dersom halvparten har vekst og den andre halvparten har nedgang.

I kartet i figur 3.13 ser vi hvordan arbeidsplassveksten i nabokommuner påvirket nettoflyttingen til kommunene i årene 2008-2014. Det er en samling av regioner med positiv nabovekst rundt Oslo, og det er også et belte med kommuner med positiv nabovekst langs Vestlandskysten, som er spesielt utpreget i siste perioden. Dette er regioner som får et løft i sin nettoflytting på grunn av at de ligger i et arbeidsmarked som har vekst, uavhengig av om de har vekst i de enkelte kommuner eller ikke. Kommuner med en positiv effekt av nabovekst drar dermed nytte av sin geografiske lokalisering. 


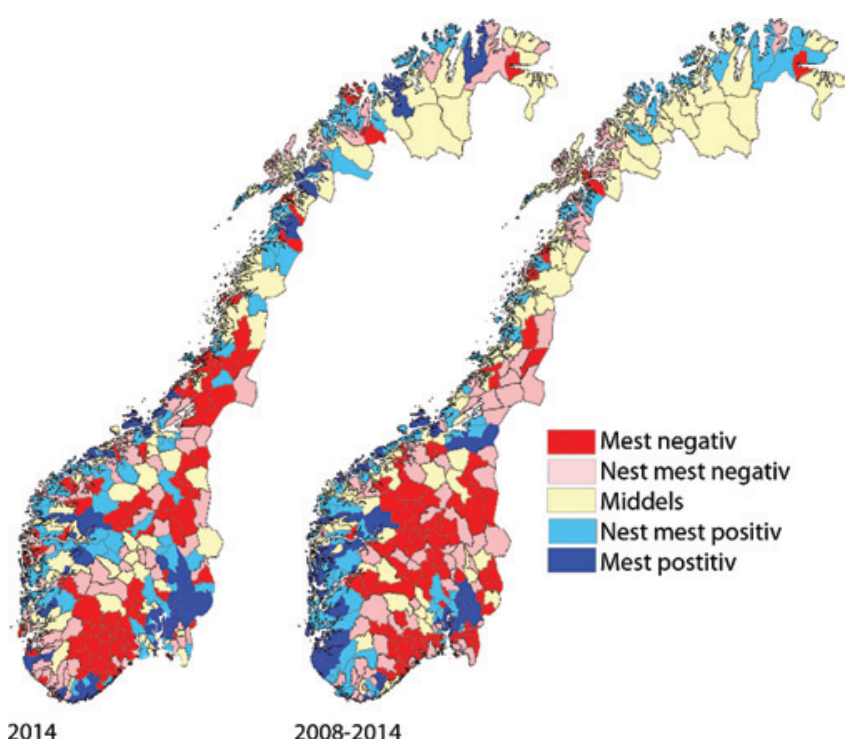

Figur 3.13 Nettoflyttingens effekt på arbeidsplassveksten i nabokommuner i to perioder. Kartet viser naboveksten for kommunene.

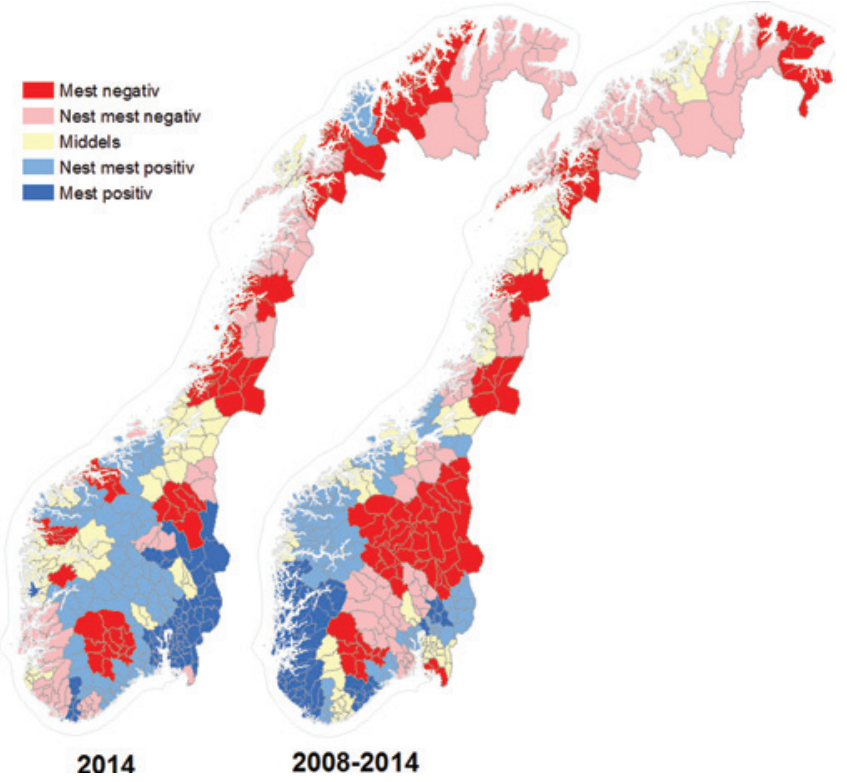

Figur 3.14 Nettoflyttingens effekt på arbeidsplassveksten i nabokommuner i to perioder. Kartet viser naboveksten for regionene. 
Vi kan se at nabovekstens innflytelse på nettoflyttingen virker sentraliserende. Områdene rundt Oslo, Stavanger, Bergen og Trondheim har hatt en positiv effekt av naboveksten, mens perifere områder har hatt negativ effekt.

Noen strukturelle trekk blir mer tydelige når vi bruker regioninndeling $\mathrm{i}$ stedet. I figur 3.14 under har vi vist effekten av arbeidsplass i naboregionene.

Nå kan vi se enda tydeligere at Vestlandet har hatt en positiv stimulans fra arbeidsplassvekst i perioden 2008-2014. Denne perioden kjennetegnes av at oljerelaterte bransjer har hatt sterk vekst, samtidig med at ikke-oljerelatert konkurranseutsatt næringsliv har stagnert eller hatt nedgang. Regionene på Vestlandet har hatt en næringsdrevet vekst i denne perioden, mens Oslo og Akershus har hatt en befolkningsdrevet vekst.

Oljekrisen, som inntraff på slutten av 2014, førte til en endring av dette mønsteret. Kartet til venstre i figur 3.14 som viser effekten av naboveksten i 2014 isolert, har et ganske annet mønster. Nå er det stort sett bare Østlandet som har mørkeblå regioner, mens mange av regionene på Vestlandet har blitt rosa eller røde.

\subsubsection{Kommuner med størst og minst effekt av nabovekst}

Det kan være interessant å se hvilke kommuner som har hatt størst gevinst av nabovekst, og hvilke som har hatt størst ulempe av det.

Figur 3.15 viser de kommunene som har «tjent» over en halv prosent av folketallet på grunn av økt nettoflytting som skyldes veksten i nabokommunene. Det er kommuner som ligger nær andre kommuner med høy arbeidsplassvekst, og som samtidig har mye pendling til disse kommunene. Vi kan se at disse kommunene kan deles inn i fire grupper. Den ene gruppen er kommuner i Osloregionen, der Rælingen, Fet, Gjerdrum, Skedsmo, Sørum og Enebakk er med. Den andre gruppen er i Stavangerregionen, med Time, Randaberg, Sandnes, Gjesdal, Klepp, Stavanger og Rennesøy. Sund og Øygarden ligger nær Bergen. Hareid ligger nær Ulstein.

I figur 3.16 ser vi de kommunene som har «tapt» mer enn en halv prosent av folketallet som følge av arbeidsplassnedgang i nabokommuner. Mange av disse kommunene er i Innlandet, som Sør-Fron, Jevnaker, Tolga, Vestre Slidre, Grue, Åsnes, Os og Etnedal. 


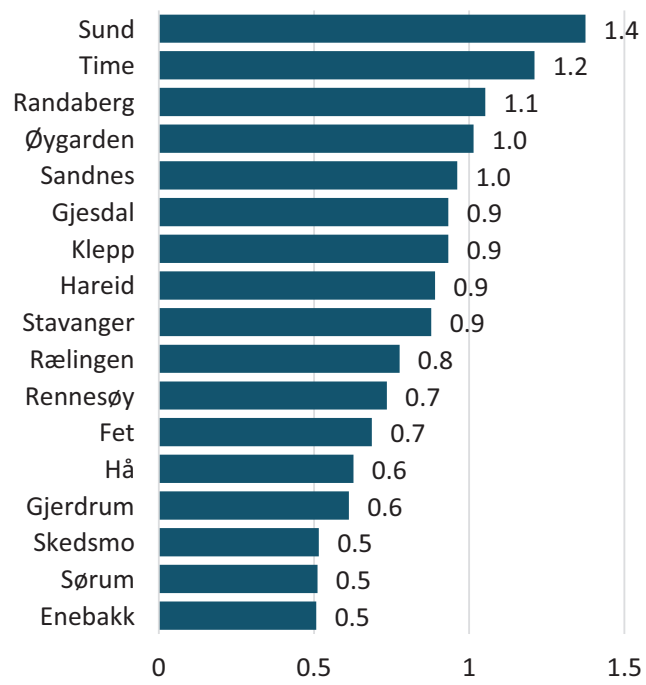

Figur 3.15 Effekten arbeidsplassvekst i nabokommuner har på nettoflytting (prosent av folketallet). Kommuner med høyest positiv effekt i perioden 2008-2014.

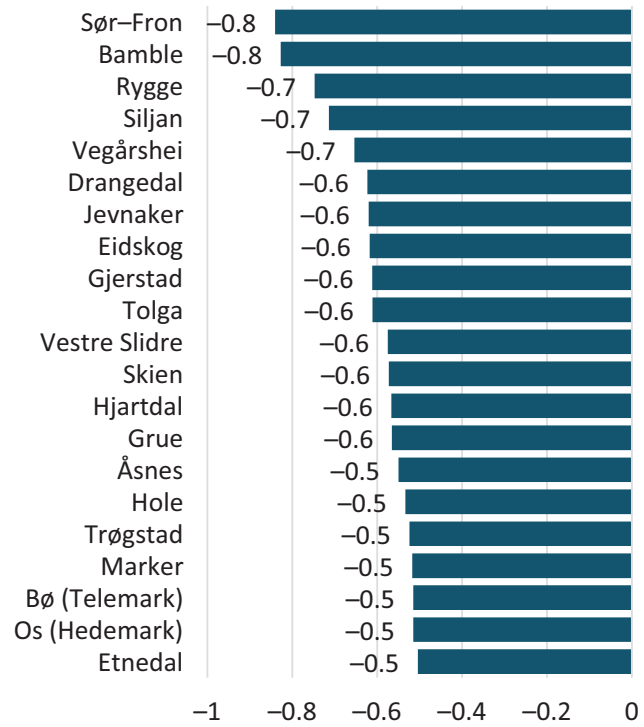

Figur 3.16 Effekten arbeidsplassvekst i nabokommuner har på nettoflytting (prosent av folketallet). Kommuner med høyest negativ effekt i perioden 2008-2014. 
Telemark har også flere kommuner med her, som Skien, Bamble, Siljan, Drangedal og Bø. Rygge, Eidskog, Trøgstad og Marker er med fra Østfold. Utenom disse områdene er det bare Hole og Vegårdshei som er med.

\subsubsection{Nettoflytting, egen arbeidsplassvekst og nabovekst}

Vi kan nå se på faktisk nettoflytting i forhold til forventet nettoflytting $\mathrm{i}$ kommunene ut fra egen arbeidsplassvekst og veksten i nabokommunene samtidig.

Forklaringskraften blir litt bedre når vi tar med arbeidsplassveksten i nabokommuner. $\mathrm{R}^{2} \varnothing$ ker fra 0,08 (se figur 3.10) til 0,09. Vekst i nabokommuner betyr en del, men er ikke en veldig sterk kraft. Det kommer av at mange kommuner har liten pendling, slik at effekten blir lav, og av at mange kommuner har nabokommuner med både vekst og nedgang, slik at effekten blir utliknet.

Når vi gjør tilsvarende analyser for regioner, får vi langt sterkere forklaringskraft. Nå er $\mathrm{R}^{2}$ på 0,37 . Mye av støyen vi får i kommuneanalysen, er borte, ettersom vi ikke har enheter med få innbyggere. Dessuten blir sammenhengen mellom arbeidsplasser og flytting sterkere når vi bruker en inndeling som ligger nærmere funksjonelle arbeidsmarkeder.

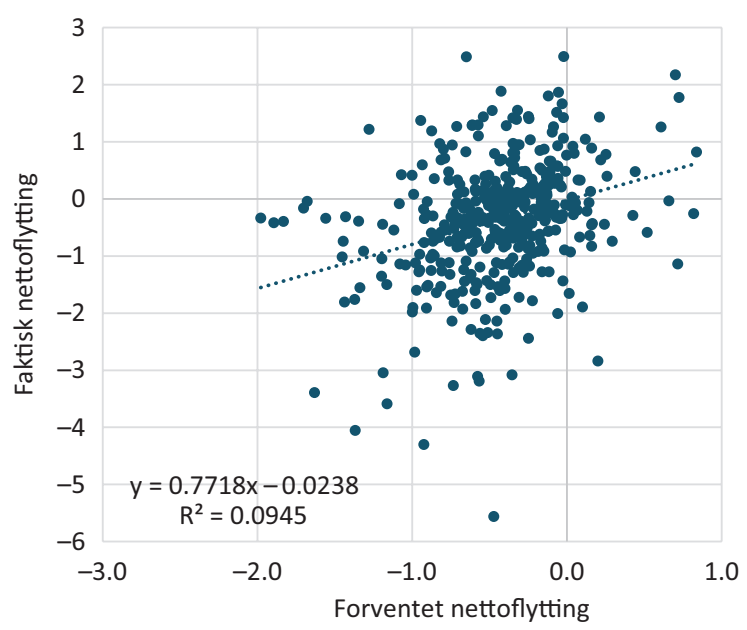

Figur 3.17 Kommuner, fordelt etter faktisk nettoflytting og forventet nettoflytting ut fra arbeidsplassvekst i egen kommune og nabokommuner i 2014. 


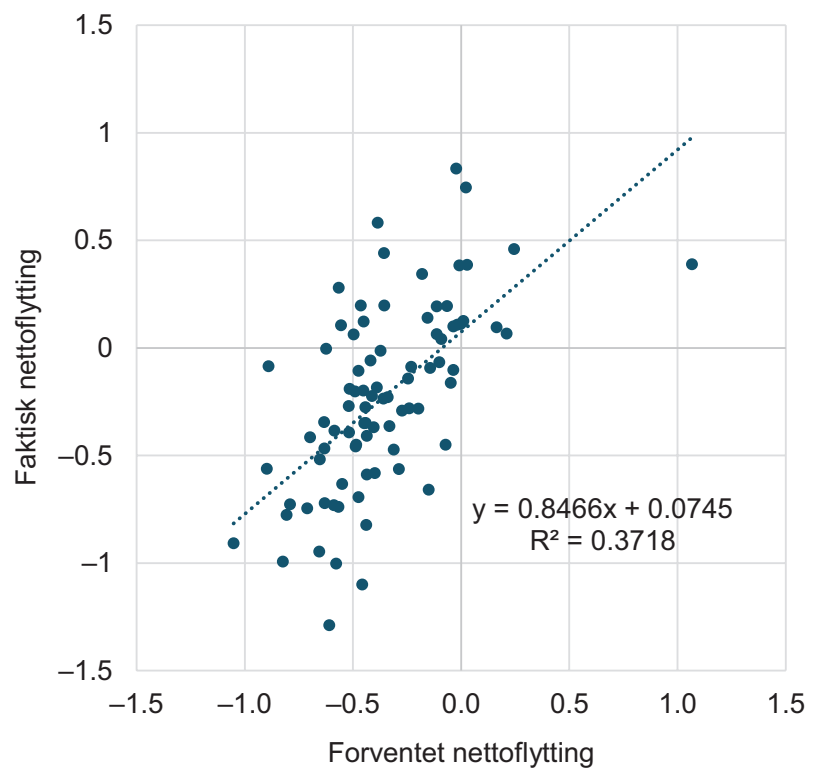

Figur 3.18 Regioner, fordelt etter faktisk nettoflytting og forventet nettoflytting ut fra arbeidsplassvekst i egen region og naboregioner i 2014.

\subsubsection{Strukturelle forhold - størrelse og arbeidsmarkedsintegrasjon}

Så langt har vi sett på arbeidsplassvekstens innvirkning på nettoflyttingen, der vi har tatt med både arbeidsplassveksten i egen kommune/region og arbeidsplassveksten i steder som det pendles til.

Hvilke andre forhold (utenom arbeidsplassvekst) påvirker nettoflyttingen til en kommune eller region?

Vi kan først se på hvilke kommuner og regioner som har høy nettoflytting, når effekten av arbeidsplassvekst i eget område og naboområder er trukket fra.

Som vi ser av figur 3.19 er det Rennesøy som har høyest «unormal» nettoflytting. I Rennesøy utgjør denne unormale nettoflyttingen over 15 prosent av folketallet i perioden 2007-2014. Kommunene med høyest unormal nettoflytting er i stor grad konsentrert til det sentrale Østlandet. Rennesøy og Finnøy ligger nær Stavanger, Meland og Os ligger inntil Bergen, Skaun ligger nær Trondheim. Giske ligger nær Ålesund. De fleste kommunene med høy unormal innflytting ligger således innenfor store og tett integrerte arbeidsmarkeder, 


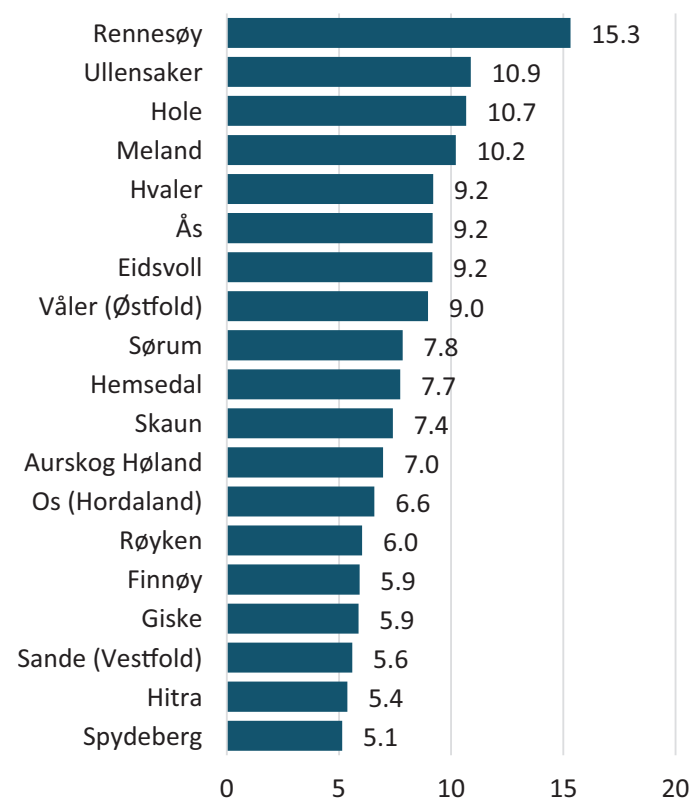

Figur 3.19 Kommuner med høyest positivt avvik mellom faktisk nettoflytting og forventet nettoflytting ut fra arbeidsplassvekst i egen kommune og nabokommuner i perioden 2007-2014.

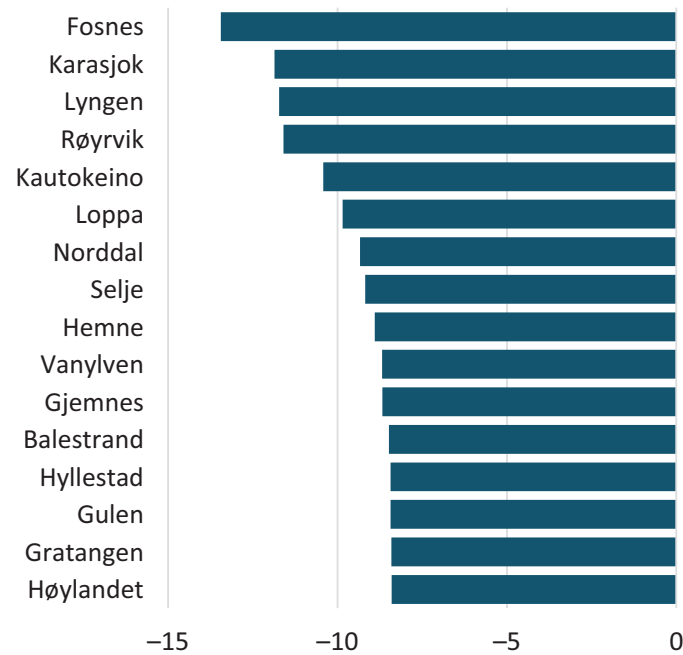

Figur 3.20 Kommuner med høyest negativt avvik mellom faktisk nettoflytting og forventet nettoflytting ut fra arbeidsplassvekst i egen kommune og nabokommuner i perioden 2007-2014. 
og har mye pendling over kommunegrensene. Unntakene på denne lista er Hemsedal og Hitra.

Lista over kommuner med unormal netto utflytting domineres av små og isolerte kommuner som er lokalisert langt fra større byer.

Det kan dermed se ut til at det er et mønster, der kommuner med høy arbeidsintegrasjon har systematisk bedre nettoflytting enn kommuner med lav arbeidsmarkedsintegrasjon, etter at effektene av arbeidsplassvekst i egen kommune og nabokommuner er trukket fra. Vi skal også se om ikke kommunens egen størrelse, i folketall, også kan ha en positiv effekt på nettoflyttingen. Kommunene i den øverste figuren er i snitt langt større enn kommunene i den nederste.

\subsubsection{Arbeidsmarkedsintegrasjon}

Arbeidsmarkedsintegrasjon er et begrep som forteller hvor godt arbeidsmarkedet på et sted er integrert i arbeidsmarkedet utenfor stedet. Arbeidsmarkedsintegrasjon kommer til uttrykk gjennom pendling ut fra og inn til stedet. Dersom et sted verken har pendling ut eller inn, er arbeidsmarkedsintegrasjonen lik null. Jo større andel av de sysselsatte som pendler ut, desto bedre integrert er arbeidsmarkedet på stedet med arbeidsmarkedet utenfor kommunen. Arbeidsmarkedsintegrasjonen kommer også til uttrykk gjennom innpendling, og er sterkere dess større andel av arbeidsplassene på stedet det pendles inn til. Vi bruker følgende formel for å beregne arbeidsmarkedsintegrasjonen:

Arbeidsmarkedsintegrasjon $=100 \times\left(\frac{\text { Antall som pendler ut }}{\text { Sysselsetting }}+\frac{\text { Antall som pendlerinn }}{\text { Arbeidsplasser }}\right)$

Lørenskog er den kommunen i landet med høyest arbeidsmarkedsintegrasjon i 2014. Arbeidsmarkedsintegrasjonen er ganske stabil, og endrer seg lite fra år til år. Det er imidlertid en tendens til at arbeidsmarkedsintegrasjonen øker over tid, etter hvert som en større andel av befolkningen pendler over kommunegrenser. Værøy er den kommunen i landet med lavest arbeidsmarkedsintegrasjon. Vi kan se at arbeidsmarkedsintegrasjonen fanger opp mye av den samme tendensen som vi viste i kapitlet om lekkasje. Arbeidsmarkedsintegrasjonen gjør at det blir større lekkasje av arbeidsplassvekstens effekt på nettoflyttingen. Nå skal vi bruke arbeidsmarkedsintegrasjonen på en annen måte. 
Ut $\square$ Inn

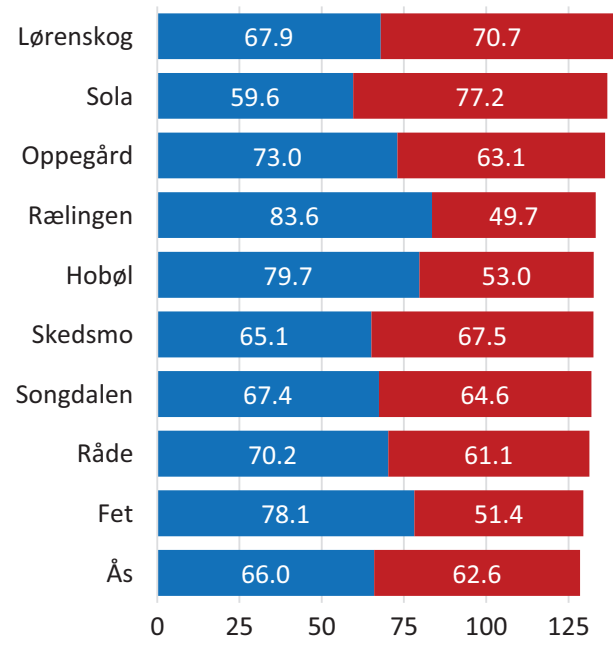

Figur 3.21 Kommuner med høyest arbeidsmarkedsintegrasjon i 2014 .

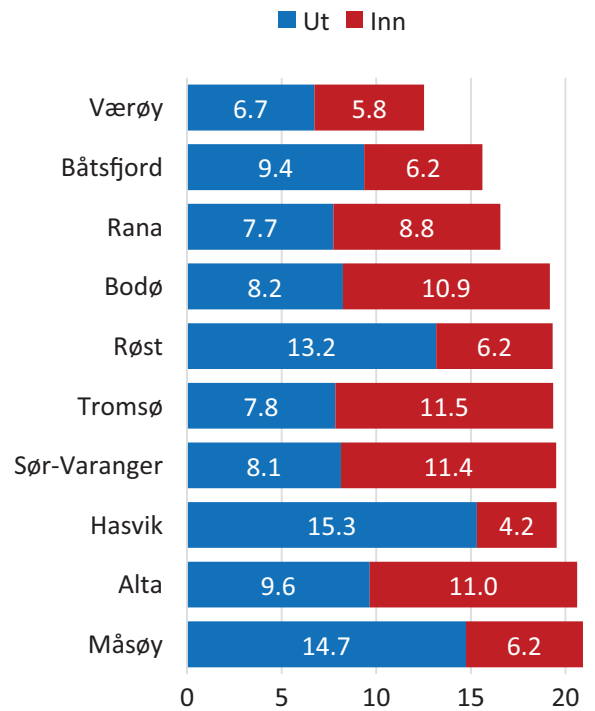

Figur 3.22 Kommuner med lavest arbeidsmarkedsintegrasjon i 2014. 
Arbeidsmarkedsintegrasjon er en stedlig egenskap som gjør at nettoflyttingen blir bedre. Steder med høy arbeidsmarkedsintegrasjon trekker til seg innflytting i større grad enn steder med lav arbeidsmarkedsintegrasjon.

\subsubsection{Arbeidsmarkedsintegrasjon og nettoflytting kommuner}

I figur 3.23 ser vi sammenhengen mellom arbeidsmarkedsintegrasjon og nettoflytting i kommunene.

Det er en tydelig positiv sammenheng mellom kommunenes nettoflytting og arbeidsmarkedsintegrasjon. Kommuner med høy arbeidsmarkedsintegrasjon har systematisk bedre nettoflytting enn kommuner med lav arbeidsmarkedsintegrasjon. Denne sammenhengen er positiv, også når vi korrigerer for arbeidsplassveksten i kommunene. Det kan dermed se ut til at sammenhengen er forårsaket av at kommuner med høy arbeidsmarkedsintegrasjon trekker til seg innflyttere (alternativt får mindre utflytting) enn kommuner som har lav arbeidsmarkedsintegrasjon.

Dette kan forklares av at en innbygger som er bosatt i en kommune med høy arbeidsmarkedsintegrasjon, vil ha langt flere jobber å velge blant enn en innbygger i en kommune av samme størrelse med lav arbeidsmarkedsintegrasjon.

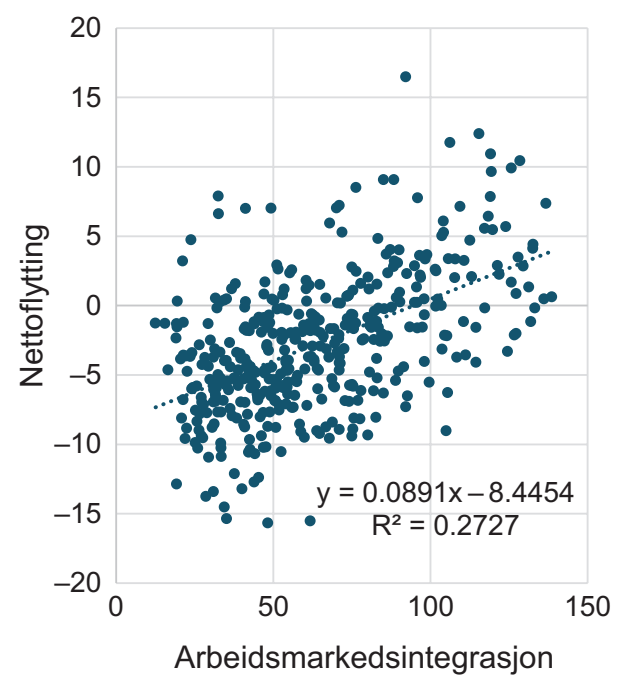

Figur 3.23 Kommunene i Norge, etter nettoflytting i perioden 2007-2014 og arbeidsmarkedsintegrasjon. 
Det gjør at flere vil ønske å bosette seg i kommunen med høy arbeidsmarkedsintegrasjon.

\subsubsection{Arbeidsmarkedsintegrasjon og nettoflytting regioner}

Arbeidsmarkedsintegrasjonen påvirker også nettoflyttingen på regionnivå. Effekten er mindre sterk enn for kommuner. Det kommer av at det er langt mindre pendling mellom regionene enn mellom kommunene. Regionene er i mye sterkere grad egne arbeidsmarkeder. Likevel har arbeidsmarkedsintegrasjonen en klar og tydelig effekt på nettoflyttingen til regionene.

\subsubsection{Intern arbeidsmarkedsintegrasjon regioner}

Den interne arbeidsmarkedsintegrasjonen er et mål for hvor mye pendling det er mellom kommunene i en region. Vi måler denne med å lage et gjennomsnitt av kommunenes utpendling til andre kommuner i regionen, og innpendlingen fra andre kommuner i regionen.

Hvis det er mye pendling mellom kommunene i regionen, er det en høy intern arbeidsmarkedsintegrasjon. Hvis det er liten pendling, danner de enkelte kommunene sine egne små arbeidsmarkeder. Figuren viser at de

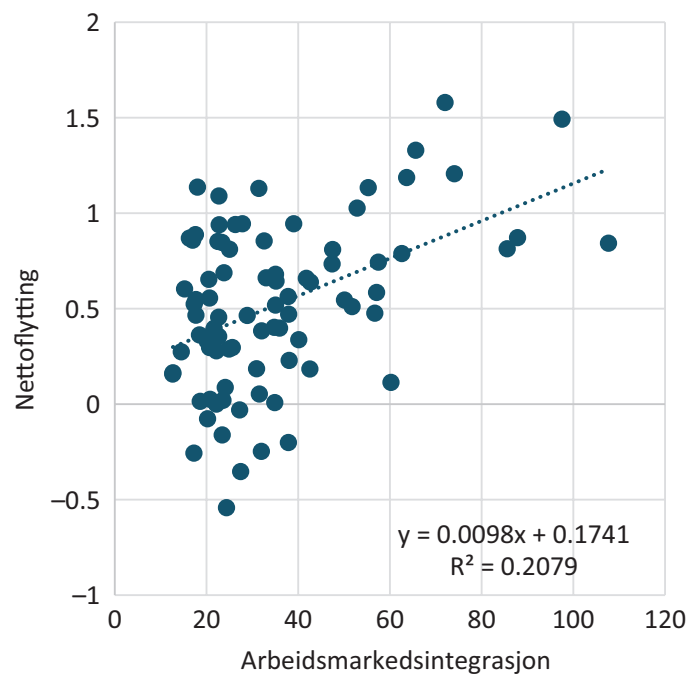

Figur 3.24 Regionene i Norge, etter nettoflytting i perioden 2007-2014 og arbeidsmarkedsintegrasjon. 
regionene med høy intern arbeidsmarkedsintegrasjon trekker til seg mer flytting enn de med lav arbeidsmarkedsintegrasjon.

I figur 3.25 har vi satt inn regionene etter verdien til den interne arbeidsmarkedsintegrasjonen og nettoflyttingen. Det er en klar korrelasjon mellom den interne arbeidsmarkedsintegrasjonen og nettoflyttingen. Stavanger- og Kristiansandregionen er regionene med sterkest intern arbeidsmarkedsintegrasjon. Regionene Øvre Romerike og Bjørnefjorden har høy nettoflytting uten å ha sterk intern arbeidsmarkedsintegrasjon. I disse regionene er det liten pendling på tvers, men stor utpendling til henholdsvis Oslo og Bergen. Disse regionene har sterk ekstern arbeidsmarkedsintegrasjon.

\subsubsection{Intern arbeidsmarkedsintegrasjon fylker}

Også for fylker finner vi en ganske sterk sammenheng mellom intern arbeidsmarkedsintegrasjon og nettoflytting. Fylker som Østfold, Rogaland og Vestfold har sterk intern arbeidsmarkedsintegrasjon. Man kan bo i hvilken som helst

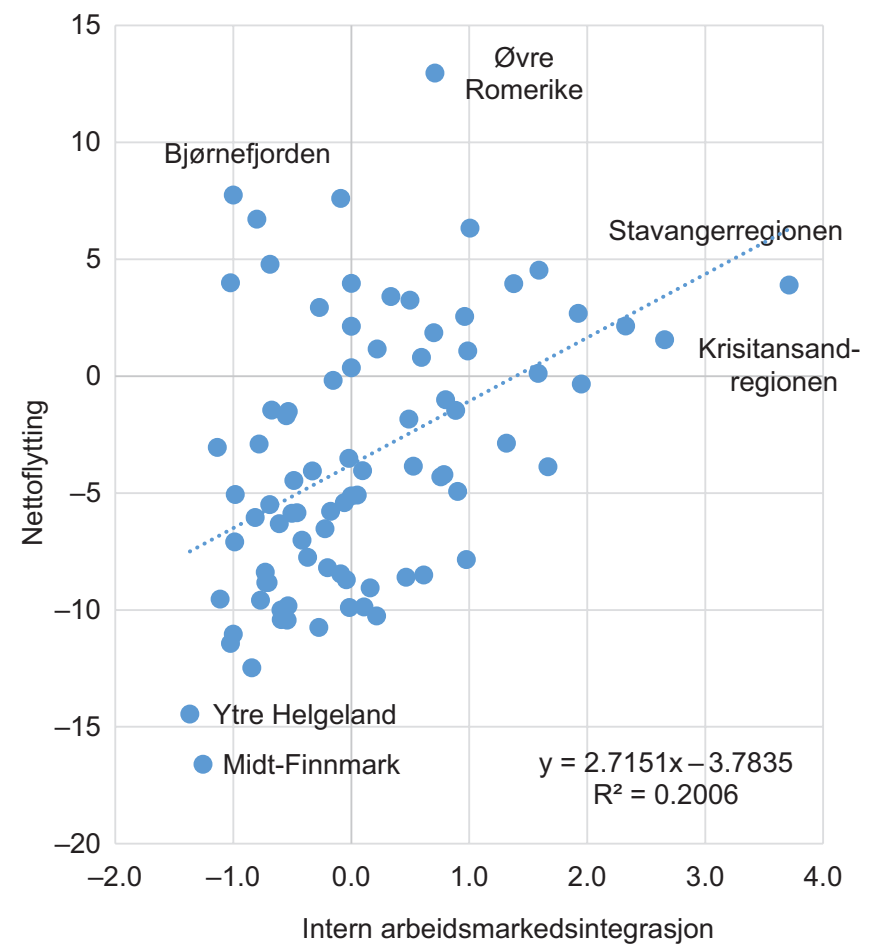

Figur 3.25 Regionene i Norge, etter nettoflytting i perioden 2003-2015 og intern arbeidsmarkedsintegrasjon. 


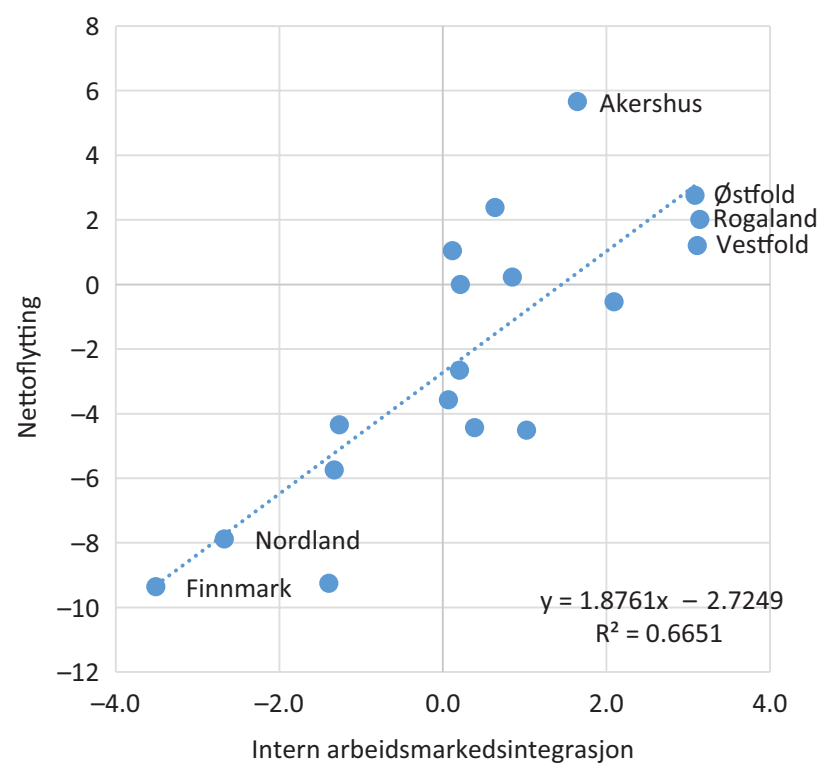

Figur 3.26 Fylkene i Norge, etter nettoflytting i perioden 2003-2015 og intern arbeidsmarkedsintegrasjon.

kommune og arbeide i hvilken som helst. Innbyggerne får dermed mange valgmuligheter for jobb.

Finnmark og Nordland har lav intern arbeidsmarkedsintegrasjon. Arbeidsmarkedene i disse fylkene er splittet opp i mange små. Dermed blir det færre valgmuligheter for innbyggerne.

\subsubsection{Nettoflytting og størrelse}

Store, i betydningen folkerike, kommuner har systematisk høyere nettoflytting enn kommuner med få innbyggere. Det kan vi se av figur 3.27. Store kommuner vil, alt annet likt, trekke til seg mer innflytting enn små kommuner.

Vi har da vist at flyttingen til et sted påvirkes av tre strukturelle faktorer: arbeidsplassvekst i nabokommuner (som det pendles til), arbeidsmarkedsintegrasjon og størrelse.

\subsubsection{En modell for forventet nettoflytting}

Vi har så langt sett på et sett med faktorer som har en signifikant påvirkning på nettoflyttingen, og vist hvordan de virker hver for seg. I tabellen under ser vi 


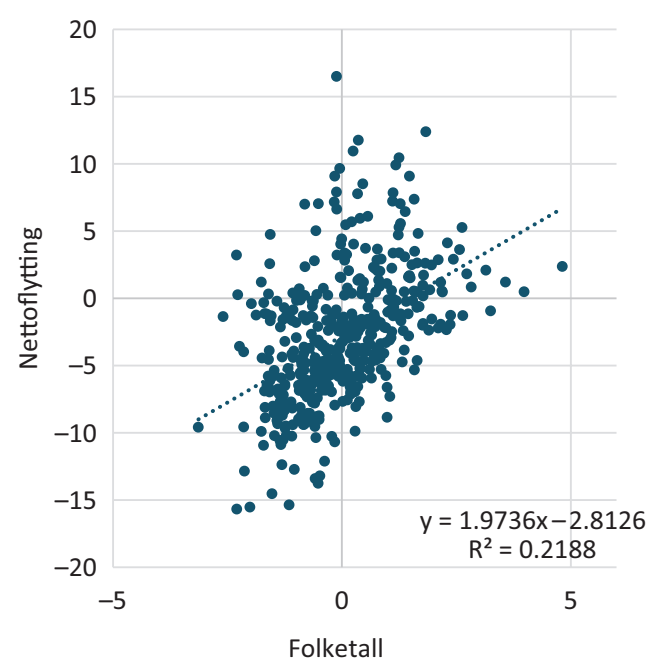

Figur 3.27 Sammenhengen mellom nettoflytting (2007-2014) og folketall (naturlig logaritme).

resultatene av analysene, der vi viser betaverdiene til de ulike faktorene på kommune-, region- og fylkesnivå. Vi har da kjørt en multippel regresjonsanalyse i to trinn. Først har vi kjørt en regresjonsanalyse med nettoflytting som avhengig variabel og arbeidsplassveksten i de tre siste årene som tre uavhengige variabler. Det vil si at nettoflyttingen antas å være en lineær funksjon av arbeidsplassveksten i de tre siste årene, etter formelen:

flytting $=\mathrm{b}_{1}$ * arbeidsplassvekst år $\mathrm{t}+\mathrm{b}_{2}$ * arbeidsplassvekst år $\mathrm{t}-1+\mathrm{b}_{3}$ * arbeidsplassvekst i år $\mathrm{t}-2$ + restledd

Restleddet fra denne regresjonsanalysen har vi da brukt som indikator for det vi kaller «brutto bostedsattraktivitet». Dernest har vi kjørt en ny regresjonsanalyse hvor brutto bostedsattraktivitet er avhengig variabel, mens nabovekst, størrelse (logaritmen til folketallet), arbeidsmarkedsintegrasjon og intern arbeidsmarkedsintegrasjon (ikke for enkeltkommuner) er uavhengige variable på formen:

brutto bostedsattraktivitet $=\mathrm{b}_{4}{ }^{*}$ nabovekst $+\mathrm{b}_{5}{ }^{*}$ folketall (logaritmen) $+\mathrm{b} 6{ }^{*}$ arbeidsmarkedsintegrasjon $+\mathrm{b}_{7}{ }^{\star}$ intern arbeidsmarkedsintegrasjon + restledd

Når vi kjører regresjonsanalysene, vil vi få beregninger av størrelsen til betaverdiene fra formlene over. Verdiene av betaverdiene for data fra perioden 2000 til 2015 er vist i tabell 3.3.

Vi har tidligere omtalt verdiene for arbeidsplassveksten. Det vi kan se, er at arbeidsplassveksten har størst forklaringskraft $\left(\mathrm{R}^{2}\right)$ på regionnivået. Det er 
Tabell 3.3 Resultater fra regresjonsanalysene med data fra årene 2000 til 2015.

\begin{tabular}{lccc}
\hline & $\begin{array}{c}\text { Norge } \\
\text { kommuner }\end{array}$ & $\begin{array}{c}\text { Norge } \\
\text { regioner }\end{array}$ & $\begin{array}{c}\text { Norge } \\
\text { fylker }\end{array}$ \\
\hline Arbeidsplassvekst år 0 & 0,15 & 0,17 & 0,17 \\
Arbeidsplassvekst år -1 & 0,09 & 0,12 & 0,10 \\
Arbeidsplassvekst år -2 & 0,07 & 0,10 & 0,08 \\
R2 arbeidsplassvekst & 0,51 & 0,60 & 0,43 \\
Nabovekst & 0,18 & 0,21 & 0,25 \\
Størrelse & 0,13 & 0,07 & 0,03 \\
Arbeidsmarkedsintegrasjon & 0,65 & 0,94 & 0,89 \\
Intern arb.markedsintegrasjon & & 0,49 & 1,21 \\
R2 strukturelle & 0,43 & 0,59 & 0,81 \\
R2 totalt & 0,67 & 0,79 & 0,89 \\
\hline
\end{tabular}

regionene som er nærmest en oppdeling i funksjonelle arbeidsmarkeder. For fylker gir arbeidsplassveksten lavere forklaringskraft enn for kommuner.

For kommuner er størrelse av større betydning enn for regioner og fylker. Variasjonen i størrelse er mye større på kommunenivå, der antall innbyggere varierer fra omtrent 200 i Utsira til over 600000 i Oslo.

Den interne arbeidsmarkedsintegrasjonen har ganske stor betydning for nettoflyttingen til fylkene. Fylker som Østfold og Vestfold er fylker med sterk intern arbeidsmarkedsintegrasjon. Disse fylkene er geografisk små med korte avstander mellom kommunene. En innflytter til en av disse fylkene vil da kunne pendle til hvilken som helst av de andre kommunene i fylket. I disse to fylkene er arbeidsmarkedet i stor grad et sammenhengende funksjonelt arbeidsmarked. Det gir langt større valgfrihet for arbeid enn det er i et fylke som Nordland, der arbeidsmarkedet er oppdelt i mange små og isolerte arbeidsmarkeder.

De strukturelle flyttefaktorene har stor forklaringskraft for fylker, noe mindre for regioner og har minst å si for enkeltkommuner.

Samlet sett har modellen en svært stor forklaringskraft for nettoflytting til fylker. $\mathrm{R}^{2}$ for fylkesmodellen er samlet sett hele 0,89 . Det kan litt forenklet formuleres som at modellen forklarer 89 prosent av variasjonen i fylkenes 
nettoflytting i perioden 2000 til 2015. For regioner forklarer modellen samlet sett 79 prosent, mens for kommuner forklarer modellen 67 prosent.

Betaverdiene i tabellen over bruker vi i modellen for forventet nettoflytting. Vi har da en modell som forklarer nettoflyttingen til et sted med bare fire faktorer: arbeidsplassvekst på eget sted, arbeidsplassvekst i kommuner det pendles til, arbeidsmarkedsintegrasjon og størrelse (innbyggertall).

\subsubsection{Mønstre i de strukturelle flyttefaktorene}

Det kan være interessant å se resultatene fra analysene, spesielt hvordan de ulike strukturelle flyttefaktorene har slått ut for nettoflyttingen. I kartene i figur 3.28 ser vi hvordan de tre strukturelle flyttefaktorene (nabovekst, befolkningsstørrelse og arbeidsmarkedsintegrasjon) har slått ut på nettoflyttingen enkeltvis og samlet for perioden 2009-2014.

Kartet lengst til venstre i figur 3.28 viser hvordan arbeidsplassvekst i nabokommuner har bidratt til nettoflyttingen i perioden 2009-2014. Kommunene i Akershus, mesteparten av Vestlandet og Sør-Trøndelag er områder med sterk arbeidsplassvekst. Kommunene i disse områdene har da fått en positiv stimulans til sin nettoflytting.

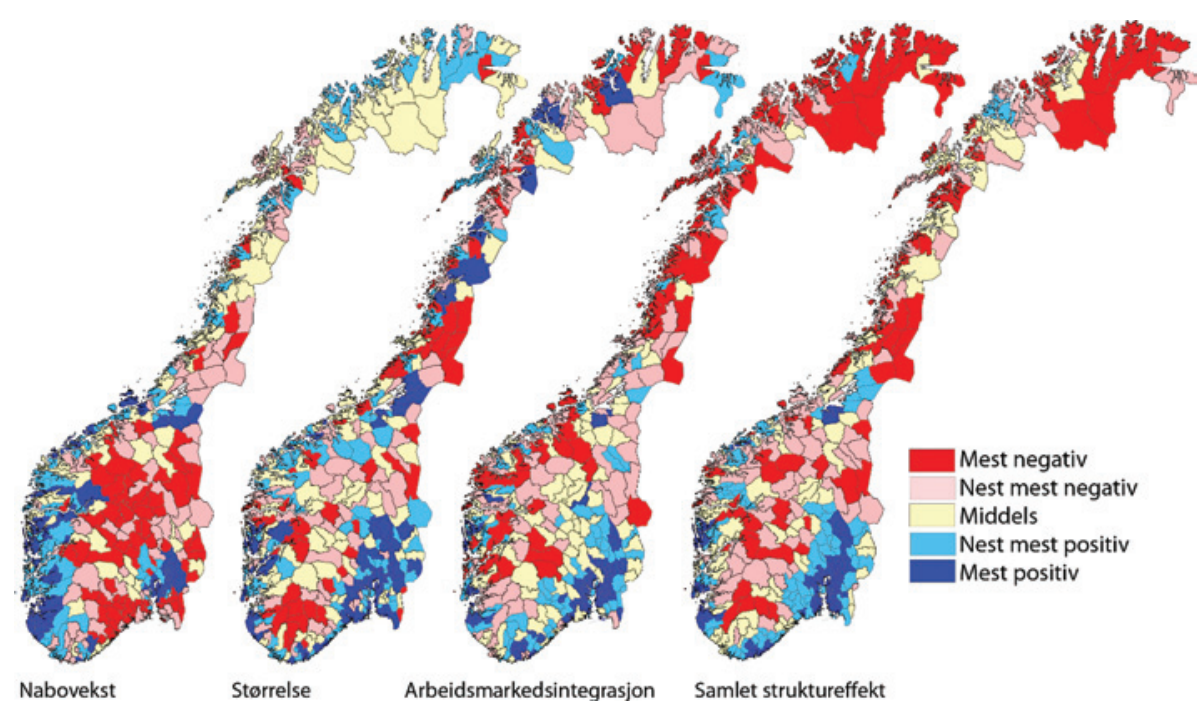

Figur 3.28 Effekt på nettoflyttingen av henholdsvis nabovekst, befolkningsstørrelse og arbeidsmarkedsintegrasjon i perioden 2009-2014. Kartet lengst til høyre viser samlet effekt. Alle kartene er sortert etter kvantiler med like mange kommuner i hver gruppe. 
Kartene med effekt fra befolkningsstørrelse og arbeidsmarkedsintegrasjon viser at områdene rundt Oslofjorden har fått positive bidrag. Omtrent hele Nord-Norge har fått negativt bidrag fra svak arbeidsmarkedsintegrasjon.

De samlede struktureffektene er vist i kartet helt til høyre. De mørkeblå kommunene er de som har fått størst positiv effekt fra de strukturelle flyttefaktorene. Vi kan se at det er kommunene rundt Oslofjorden og kommuner rundt de største byene Kristiansand, Stavanger, Bergen og Trondheim.

Hva er årsaken til effektene? En tolkning er at de reflekterer den samlede effekten av folks bostedspreferanser. Folk foretrekker å bosette seg i områder der de når et stort arbeidsmarked. Det gir flere muligheter på arbeidsmarkedet.

\subsection{Strukturelle drivkrefter for arbeidsplassutvikling}

Nå har vi vært igjennom de strukturelle forholdene for nettoflytting, og hvordan vi lager en modell for forventet nettoflytting på et sted, med noen ganske få forklaringsvariabler. Nå skal vi gjøre den samme øvelsen for arbeidsplassvekst i næringslivet. Vi er interessert i å identifisere strukturelle drivere for arbeidsplassveksten slik at vi også får en modell for forventet arbeidsplassvekst på et sted.

\subsubsection{Sektorer, næringstyper og bransjer}

Begrepet sektor brukes om privat og offentlig sektor. Offentlig sektor kan igjen deles opp i stat, fylke og kommune. Arbeidsplasser i offentlige institusjoner defineres da som offentlige arbeidsplasser. Privat sektor, som er synonymt med næringsliv, består av en rekke selskapstyper, som aksjeselskaper, enkeltmannsforetak, ansvarlige selskaper, stiftelser, foreninger og mange flere. Aksjeselskaper regnes med i privat sektor selv om de er eiet av offentlige institusjoner. I vår modell forsøker vi ikke å analysere hvorfor offentlig sektor vokser, eller hvorfor det er regionale forskjeller i veksten i offentlig sektor. Antall arbeidsplasser i det offentlige er en såkalt eksogen faktor. Vi konsentrerer oss om å analysere privat sektor.

Næringslivet er mangfoldig, og det er derfor hensiktsmessig å dele det opp. Det finnes mange ulike måter å dele opp næringslivet. Vi bruker en oppdeling med fire strategiske næringstyper, som igjen er delt opp i 22 ulike bransjer. 


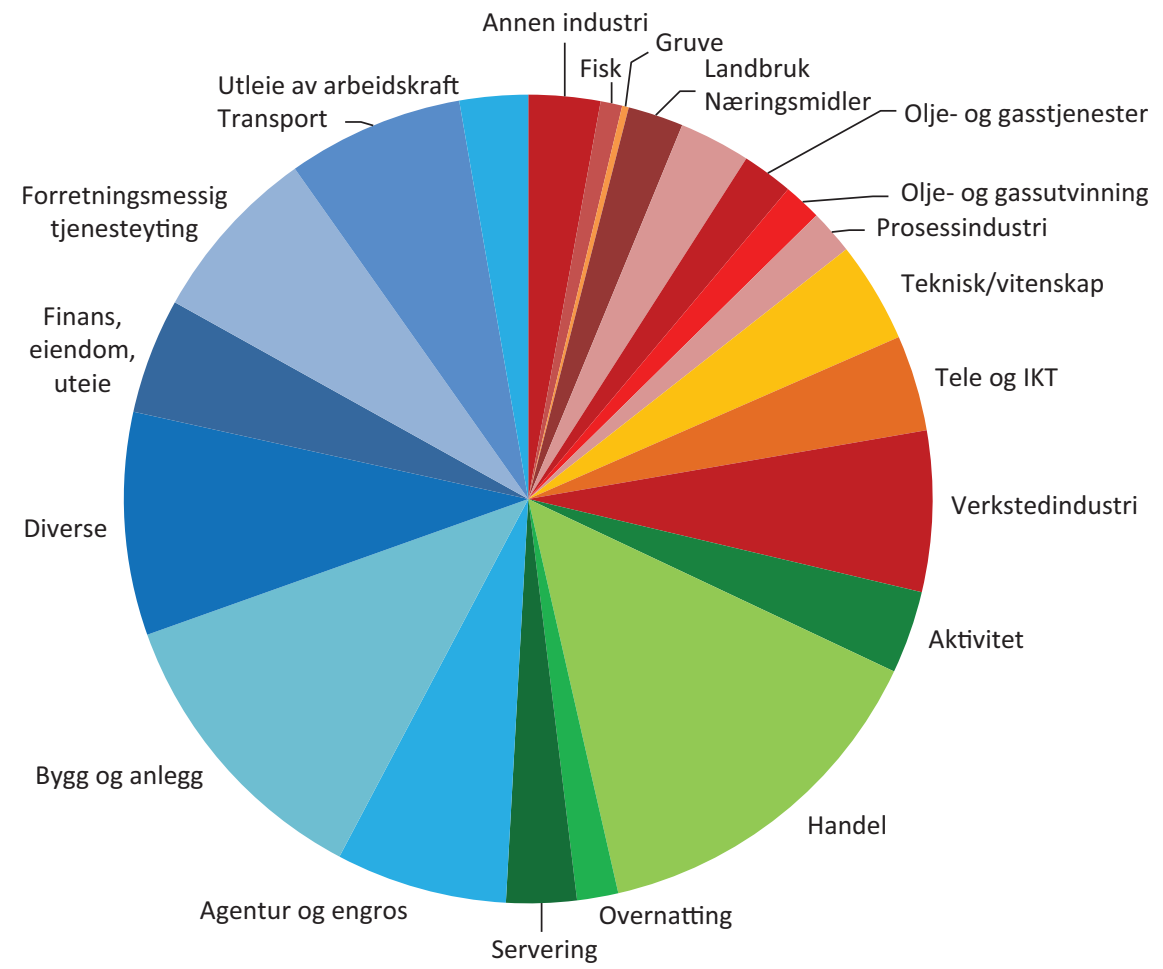

Figur 3.29 Inndeling av næringslivet, utenom de lokale næringene. De røde/gule er bransjer i basisnæringer, de grønne besøksnæringer og de blå regionale næringer.

Basisnæeringer er næringsliv som konkurrerer på et nasjonalt eller internasjonalt marked. Basisnæringene produserer varer eller tjenester på et sted, som selges og konsumeres hovedsakelig i et marked utenfor stedet der produksjonen foregår. Primær- og sekundærnæringer som landbruk, gruver og industri, tilhører basisnæringene. Også en del tjenesteproduksjon defineres som basisnæringer. Dette er tjenester som IT, telekom og andre teknologiske tjenester. Basisnæringene regnes ofte som «motoren» i økonomien. Det er tradisjonelt ut fra basisnæringene at mye annen næringsvirksomhet skapes.

Besøksnoeringer er næringsliv som kjennetegnes av at kunden må være personlig til stede. Besøksnæringene inkluderer derfor all turisme, men også butikkhandel og en del personlige tjenester. Både stedets egne innbyggere og tilreisende er kunder som etterspør tjenester fra besøksnæringene.

De regionale noeringene består av bransjer som har både annet næringsliv, offentlige institusjoner og befolkning som kunder i et hovedsakelig 
regionalt marked. Eksempler på slike næringer er bygg og anlegg, transport og forretningsmessig tjenesteyting. Vi finner ofte en konsentrasjon av slike regionale næringer i byer og sentra. Det er en sammensatt næringstype, og vi antar at det er ulike drivere for vekst og utvikling i de ulike bransjene i de regionale næringene.

Lokale næeringer er privat næringsliv som leverer tjenester til den lokale befolkningen. Dette er tjenester som private barnehager, skoler, primærhelsetjenester og renovasjon. De lokale næringene er som regel substitutter for offentlige tjenester og er svært tett knyttet til egen befolkning. I analysene framover vil vi derfor slå sammen kommunal sektor og lokale næringer.

Utviklingen i antall arbeidsplasser i de ulike næringstypene og sektorene har vært noe forskjellig siden 2000, som vi viser i figur 3.30.

Basisnæringene har de klart sterkeste konjunktursvingningene. Basisnæringene har også hatt klart lavest vekst siden 2000. Besøksnæringene vokste raskest fram til 2007, men har stagnert litt etter det. De regionale næringene har vokst raskest av de tre næringstypene, mens offentlig sektor vokser raskest og mest stabilt.

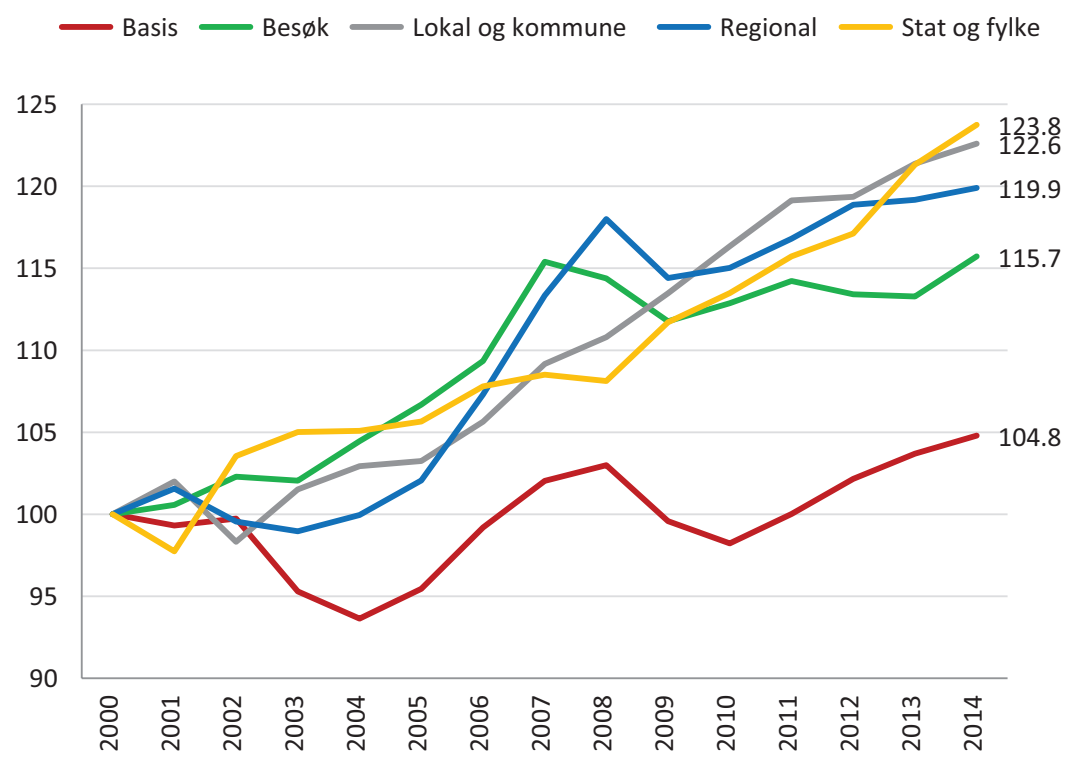

Figur $\mathbf{3 . 3 0}$ Indeksert arbeidsplassvekst i de ulike næringstypene og i offentlig sektor i Norge fra 2000 til2014. 


\subsubsection{Vekst i enkeltbransjer}

De enkelte bransjene har mye større variasjon i veksten enn næringstypene. I figuren til høyre ser vi hvordan utviklingen i antall arbeidsplasser har vært i de ulike bransjene fra 2000 til 2014.

De største variasjonene finner vi i bransjene som er definert som basisnæringer. Tjenester til olje- og gassutvinning har nesten doblet antall ansatte i denne perioden. Tekniske/vitenskapelige tjenester har hatt en vekst på 73,5 prosent. Samtidig har noen bransjer hatt sterk nedgang, som prosessindustri, landbruk og annen industri (som inneholder blant annet trevare og møbler). I noen bransjer skyldes nedgangen at produksjonen i Norge går ned. I andre

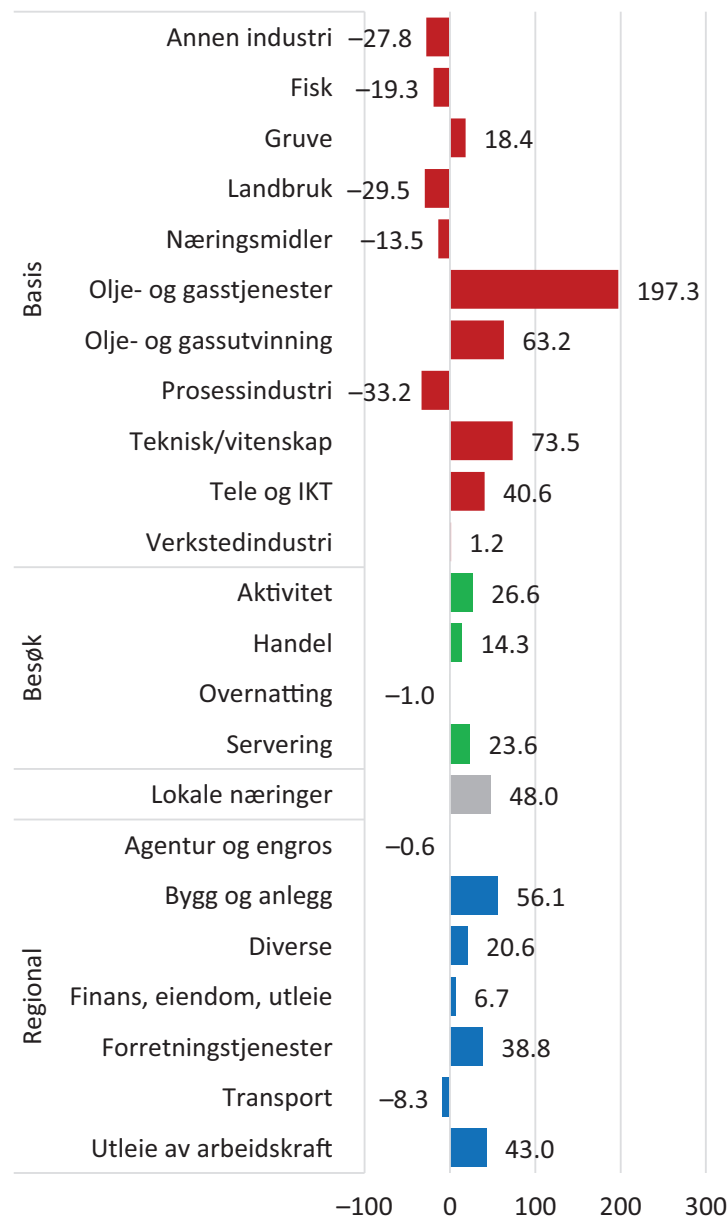

Figur 3.31 Prosentvis arbeidsplassvekst i de ulike bransjene i Norge i perioden 2000-2014. 
bransjer opprettholdes eller øker produksjonsvolumet, mens antall sysselsatte går ned på grunn av rasjonalisering og automatisering. Hvis vi sammenlikner antall ansatte med den økonomiske verdiskapingen, kan vi finne ut om det er produksjonsnedgang eller rasjonalisering som er årsaken. For vårt formål er det ikke nødvendig. Poenget er at noen bransjer vokser i antall sysselsatte, mens andre krymper.

De ulike bransjene i basisnæringene har ofte en sterk konsentrasjon til noen få steder, mens andre steder helt mangler noen bransjer i basisnæringene. Når samtidig veksten varierer kraftig, blir bransjesammensetningen svært viktig for veksten. Steder som har en høy konsentrasjon av vekstbransjer, vil sannsynligvis vokse, mens steder hvor næringslivet er konsentrert i nedgangsbransjer, sannsynligvis vil ha nedgang $i$ antall arbeidsplasser.

Stedenes bransjestruktur vil derfor ha stor betydning for veksten i antall arbeidsplasser i næringslivet. Bransjestrukturen er derfor et strukturelt forhold som har betydning for veksten, kanskje den aller viktigste faktoren. Vi ønsker derfor å beregne nøyaktig hva bransjestrukturen betyr for veksten på et sted.

\subsubsection{Bransjeeffekten}

En av de mest åpenbare og lettest identifiserbare årsakene til variasjon i arbeidsplassvekst mellom steder er stedenes næringsstruktur. Noen steder har hatt en stor del av arbeidsplassene i bransjer med vekst, og slike steder har normalt høy vekst. Noen steder har fått en sterk vekst de siste årene gjennom at de har en høy andel av næringslivet i vekstbransjer. Andre steder har hatt mesteparten av næringslivet i bransjer med nedgang, som prosessindustri eller landbruk. Slike steder har normalt nedgang i arbeidsplassveksten.

Logikken bak bransjeeffekten er at det «normale» er at et sted har samme vekst bransje for bransje som landet. Vi kan da simulere hvilken samlet arbeidsplassvekst stedet vil få, dersom de har gjennomsnittlig vekst innenfor hver bransje. Deretter beregner vi bransjeeffekten som differansen mellom den simulerte veksten og arbeidsplassveksten nasjonalt. Denne metoden kalles ofte for en shift/share- analyse.

For å regne ut bransjeeffekten for et sted trenger vi antall arbeidsplasser i hver bransje i det siste året før perioden og veksten i alle bransjene i Norge.

I tabell 3.4 viser vi et praktisk eksempel på hvordan bransjeeffekten regnes ut. 
Tabell 3.4 Utregning av bransjeeffekten i Telemark for perioden 2009-2014.

\begin{tabular}{|c|c|c|c|}
\hline Bransje & $\begin{array}{l}\text { Antall arbeidsplasser } \\
2008\end{array}$ & $\begin{array}{l}\text { Vekst i bransjen i Norge } \\
2009-2014\end{array}$ & $\begin{array}{c}\text { Normal } \\
\text { vekst }\end{array}$ \\
\hline Agentur og engros & 2280 & $-4,4$ & $-101,3$ \\
\hline Aktivitet & 1899 & 4,0 & 75,3 \\
\hline Annen industri & 2248 & $-17,9$ & $-403,5$ \\
\hline Bygg og anlegg & 6707 & 11,1 & 743,0 \\
\hline Diverse & 3653 & 1,4 & 51,4 \\
\hline Finans, eiendom, utleie & 1757 & $-3,5$ & $-61,0$ \\
\hline Fisk & 58 & $-4,5$ & $-2,6$ \\
\hline Forretningsmessig tjenesteyting & 2973 & 9,1 & 270,8 \\
\hline Gruve & 148 & 12,0 & 17,8 \\
\hline Handel & 9044 & $-1,7$ & $-157,3$ \\
\hline Landbruk & 1663 & $-19,2$ & $-318,7$ \\
\hline Næringsmidler & 614 & $-1,4$ & $-8,9$ \\
\hline Olje og gass & 24 & 92,8 & 22,3 \\
\hline Olje og gass, utvinning & 7 & 29,3 & 2,0 \\
\hline Overnatting & 842 & 4,1 & 34,2 \\
\hline Prosessindustri & 3289 & $-19,0$ & $-626,0$ \\
\hline Servering & 1465 & 13,0 & 190,2 \\
\hline Teknisk/vitenskap & 1627 & 15,9 & 258,2 \\
\hline Tele og IKT & 909 & 16,6 & 150,8 \\
\hline Transport & 2994 & $-3,7$ & $-111,8$ \\
\hline Utleie av arbeidskraft & 1298 & $-11,7$ & $-151,5$ \\
\hline Verkstedindustri & 4643 & $-4,5$ & $-208,4$ \\
\hline SUM & 50142 & 1,6 & -335 \\
\hline
\end{tabular}

Vi kan se at den første bransjen, agentur og engros, hadde 2280 arbeidsplasser i Telemark i 2008. Veksten i denne bransjen i Norge var på -4,4 prosent i perioden. Det betyr at dersom denne bransjen hadde samme vekst i Telemark som ellers i landet, ville veksten blitt -101,3 arbeidsplasser i perioden 2009-2014. Når vi summerer den simulerte veksten i alle bransjene, blir summen -335 arbeidsplasser. Det betyr at Telemark «normalt» skulle hatt en vekst på -0,7 prosent i denne perioden. Veksten i antall arbeidsplasser i næringslivet i Norge 
var på 1,6 prosent i denne perioden. Dermed er differansen mellom landets vekst og Telemarks «normale» vekst $-2,3$ prosent.

\subsubsection{Bransjeeffekt fylker}

I figuren ser vi bransjeeffekten i fylkene i perioden etter finanskrisen. Bransjeeffekten er regnet ut som vist på de foregående sidene.

Fylker som Rogaland, Oslo, Akershus og Hordaland har dratt fordel av sin næringsstruktur de siste årene. I disse fylkene har det vært en overvekt av arbeidsplasser i bransjer med høy vekst.

Rogaland har hatt den klart gunstigste næringsstrukturen. Fylket har spesielt høy konsentrasjon av bransjer knyttet til olje- og gassutvinning, som har hatt høy vekst i perioden. I denne perioden er det steder med mye oljebasert virksomhet som har vært de strukturelle vinnerne. I 2015 ser det derimot ut til at de oljebaserte regionene vil være de strukturelle taperne de neste årene. Hva som er en gunstig bransjestruktur, vil derfor variere over tid.

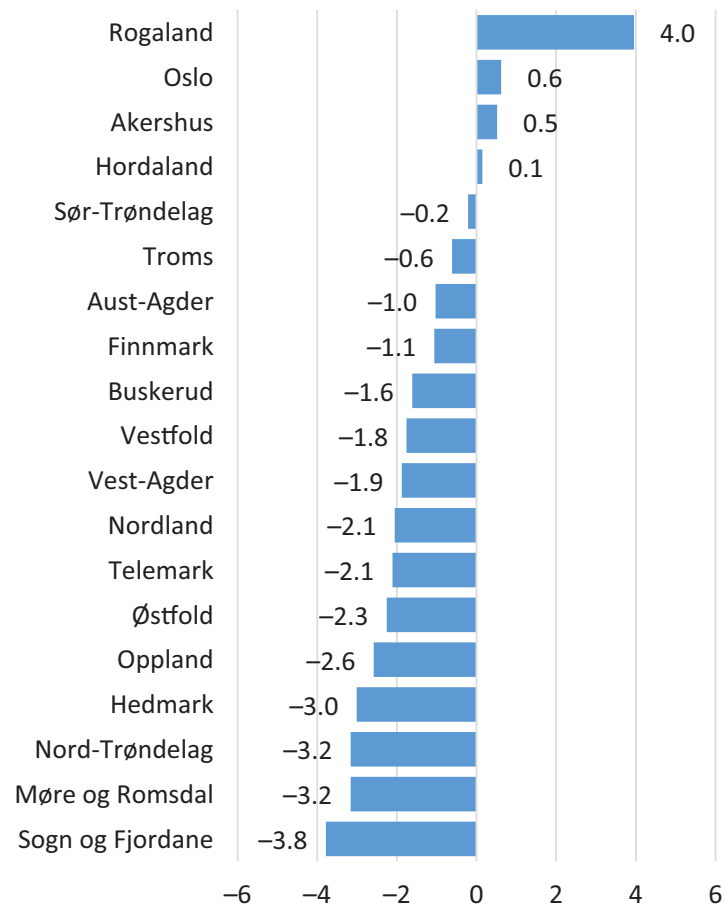

Figur 3.32 Bransjeeffekten (næringslivet) for fylkene i perioden 2009-2014. Effekten angir prosentvis avvik fra nasjonal vekst som følge av bransjestrukturen. 


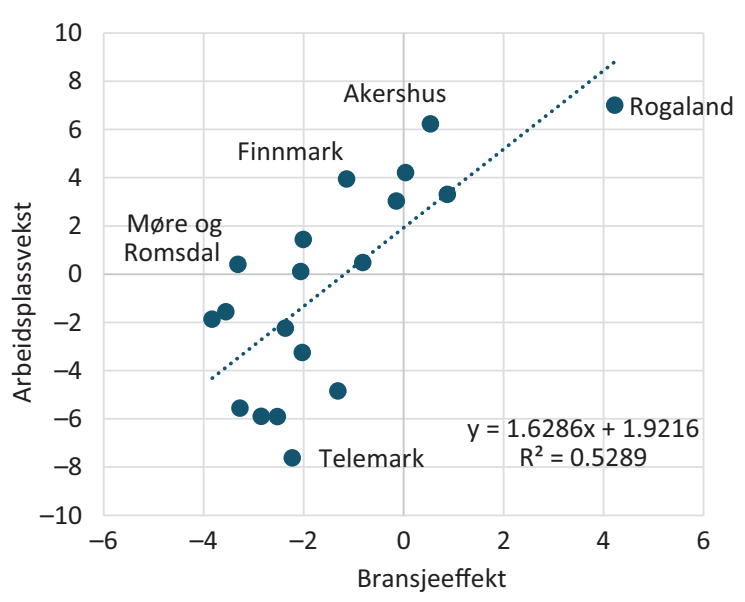

Figur 3.33 Plott med bransjeeffekt og faktisk arbeidsplassvekst i næringslivet for perioden 2009-2014 forfylkene.

I figur 3.32 ser vi et plott med bransjeeffekten og den faktiske arbeidsplassveksten i næringslivet for fylkene i den aktuelle perioden. Det er tydelig at bransjestrukturen har hatt stor betydning for variasjonene i arbeidsplassveksten. Rogaland har høyest vekst i antall arbeidsplasser, som forventet. Noen fylker har hatt høyere arbeidsplassvekst enn forventet ut fra bransjestrukturen, som Akershus, Finnmark og Møre og Romsdal. Andre fylker, for eksempel Telemark, har hatt mye lavere arbeidsplassvekst enn bransjestrukturen skulle tilsi.

Linjen som tegnes inn i figuren, er en lineær regresjon, og vi kan se at formelen er $\mathrm{y}=1,6 \mathrm{x}+1,9$. Y er da forventet arbeidsplassvekst, og $\mathrm{x}$ er bransjeeffekten. Denne formelen er ikke helt tilfredsstillende, fordi den sier at bransjeeffekten virker 1,6 ganger sterkere enn den burde. Ideelt burde vi ha en formel som er: $\mathrm{y}=\mathrm{x}+\mathrm{a}$, der a er gjennomsnittlig vekst på landsbasis i perioden. En forklaring til at bransjeeffekten får for stor betydning her, er at arbeidsplassveksten også blir påvirket av andre systematiske forhold, som korrelerer med bransjeeffekten. Vi skal se på dette senere i dette kapitlet.

\subsubsection{Bransjeeffekt regioner}

Bransjeeffekten er et resultat av at bransjestrukturen varierer mellom steder. Bransjeeffekten blir potensielt sterkere dess mindre geografisk nivå vi studerer. Et større område, for eksempel et fylke, vil alltid ha mange 


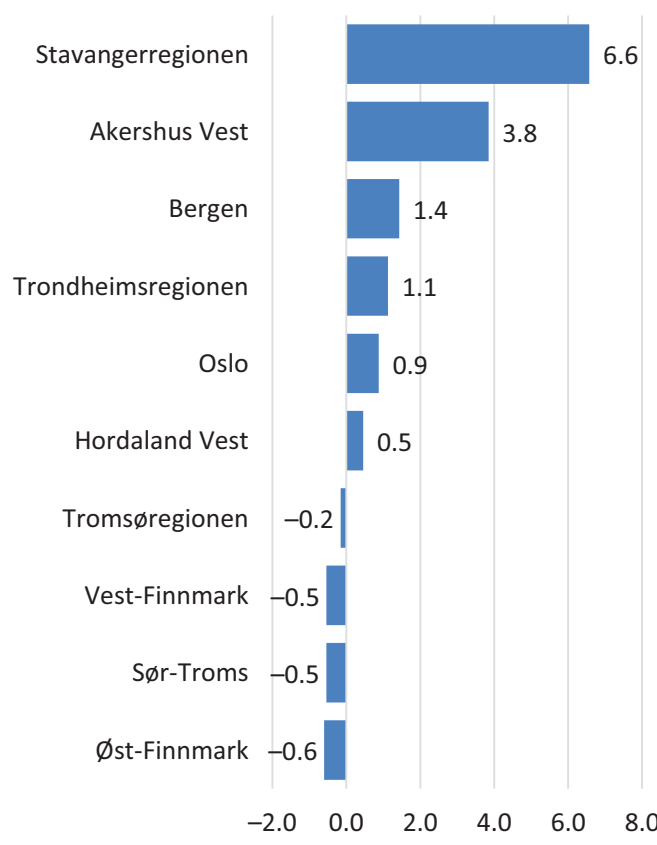

Figur 3.34 Bransjeeffekten for regioner med høyest bransjeeffekt i perioden 2009-2014. Effekten angir prosentvis avvik fra nasjonal vekst som følge av bransjestrukturen.

bransjer representert. I et lite geografisk område kan det være en langt mer spesialisert bransjestruktur. Det kan derfor være interessant å se variasjoner i bransjeeffekten i regioner og kommuner.

I figur 3.34 ser vi de ti regionene i landet med sterkest positiv bransjeeffekt. Det er interessant å merke seg at det bare er seks av de 84 regionene i landet som har positiv bransjeeffekt. Disse seks regionen er til gjengjeld blant de største regionene i landet målt i antall arbeidsplasser. Det betyr at 78 regioner har hatt en bransjesammensetning som tilsier at arbeidsplassveksten er lavere enn landsgjennomsnittet.

Stavangerregionen er den strukturelle vinneren i denne perioden. Dersom Stavangerregionen hadde hatt samme prosentvise arbeidsplassvekst i hver enkelt bransje som landet, ville den samlede arbeidsplassveksten blitt 6,6 prosentpoeng høyere der enn landsgjennomsnittet. Akershus Vest ville fått 3,8 prosent høyere vekst enn landsgjennomsnittet, mens Bergen ville fătt 1,4 prosent høyere vekst.

Figur 3.35 viser regionene med den mest uheldige bransjestrukturen i de siste seks årene. Storfjord har en bransjestruktur som ville gitt 8 prosentpoeng 
lavere vekst enn landsgjennomsnittet, selv om veksten i hver enkelt bransje var lik landsgjennomsnittet. Regioner som Indre Namdal, Fjellregionen, Sogn og Rørosregionen er også blant regionene med mest ugunstig bransjestruktur.

Vi ser dermed at de store byregionene rundt Stavanger, Oslo, Bergen og Trondheim har hatt en sammensetning i næringslivet med en overvekt av bransjer som har hatt vekst. Lista over regioner med den mest ugunstige bransjestrukturen inneholder typiske distriktsregioner. Den strukturelle utviklingen, det vil si hvilke bransjer som har hatt vekst, har dermed vært en sterkt sentraliserende kraft i denne perioden.

\subsubsection{Bransjeeffekt for kommuner}

På kommunenivå blir bransjeeffekten enda sterkere enn på regionnivået. I figur 3.36 ser vi at Randaberg har den høyeste positive bransjeeffekten av alle kommunene i denne perioden, med Sola kommune tett bak. Disse kommunene har en bransjestruktur som gir omtrent 20 prosentpoeng høyere arbeidsplassvekst i næringslivet enn gjennomsnittet for Norge.

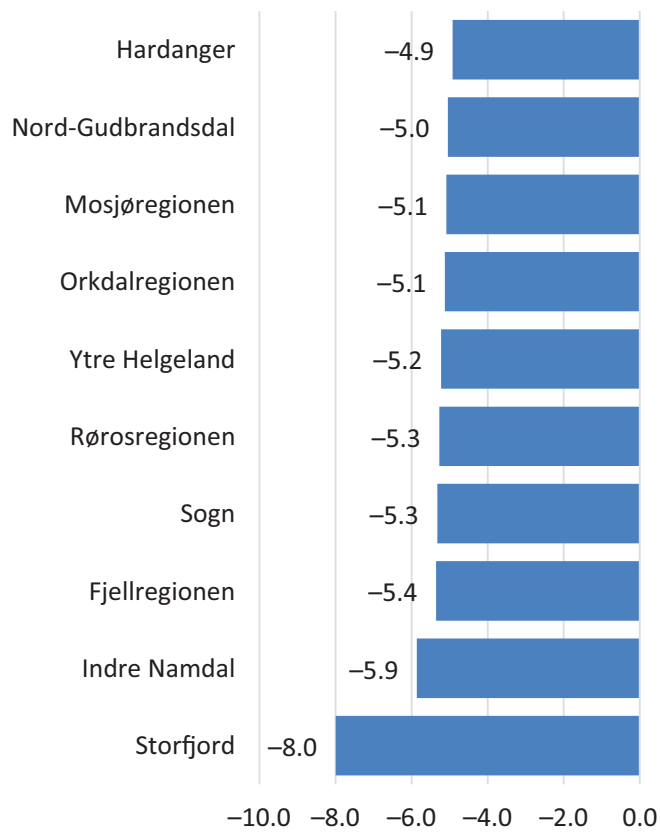

Figur 3.35 Bransjeeffekten for regioner med lavest bransjeeffekt i perioden 2009-2014. Effekten angir prosentvis avvik fra nasjonal vekst som følge av bransjestrukturen. 


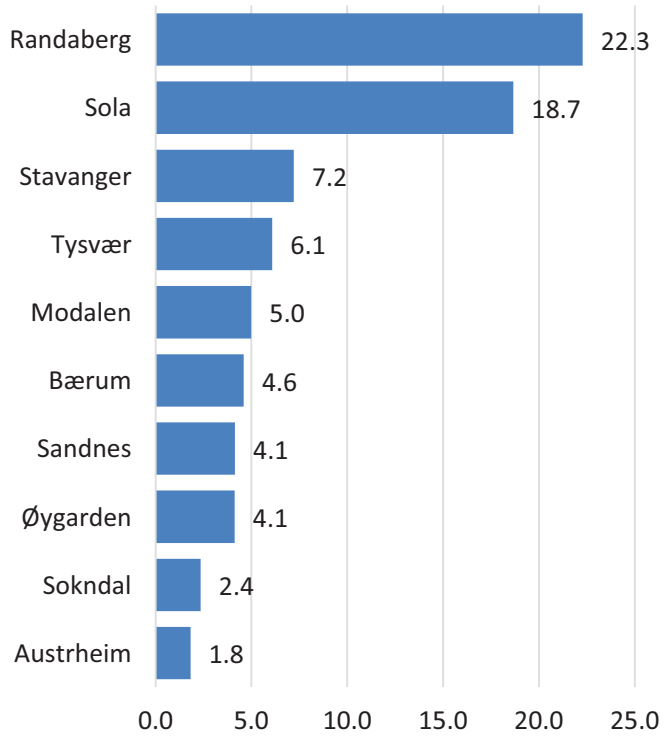

Figur 3.36 Bransjeeffekten for kommuner med høyest bransjeeffekt i perioden 2009-2014. Effekten angir prosentvis avvik fra nasjonal vekst som følge av bransjestrukturen.

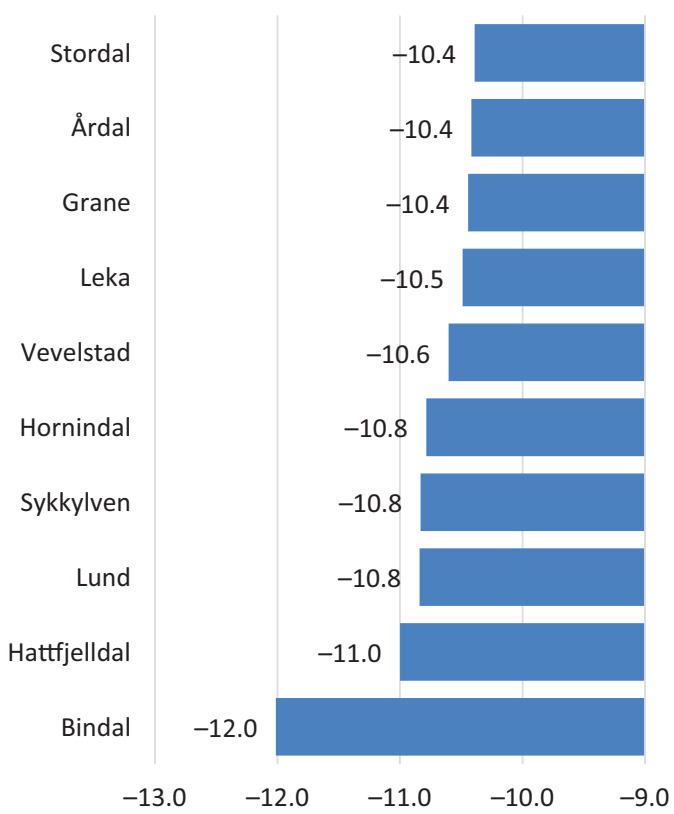

Figur 3.37 Bransjeeffekten for kommuner med lavest bransjeeffekt i perioden 2009-2014. Effekten angir prosentvis avvik fra nasjonal vekst som følge av bransjestrukturen. 
I figur 3.37 ser vi at Bindal har den klart mest negative bransjestrukturen av kommunene i perioden etter 2008.

\subsubsection{Mønstre bransjeeffekt}

Den strukturelle utviklingen i Norge i årene fra 2008 til 2014 har vært ganske sær. Perioden har vært preget av en svært sterk vekst i olje- og gassbasert næringsliv. Den sterke veksten i denne bransjen har hatt ringvirkninger til leverandørene, men kanskje også bidratt negativt til veksten i andre bransjer. Olje- og gassinntektene til Norge har ført til sterk kronekurs, drevet opp lønningene og skapt mangel på kvalifisert arbeidskraft for de fagene som oljebransjen og dens leverandører har etterspurt.

Hvis vi ser på bransjeeffekten på fylkesnivå i kartet til venstre i figur 3.38 ser vi at Rogaland er eneste fylke i gruppen med mest positiv bransjeeffekt. Avstanden ned til Oslo, som har den nest mest positive bransjeeffekten, er så stor at det ikke er noen fylker i gruppen med nest mest positiv bransjeeffekt.

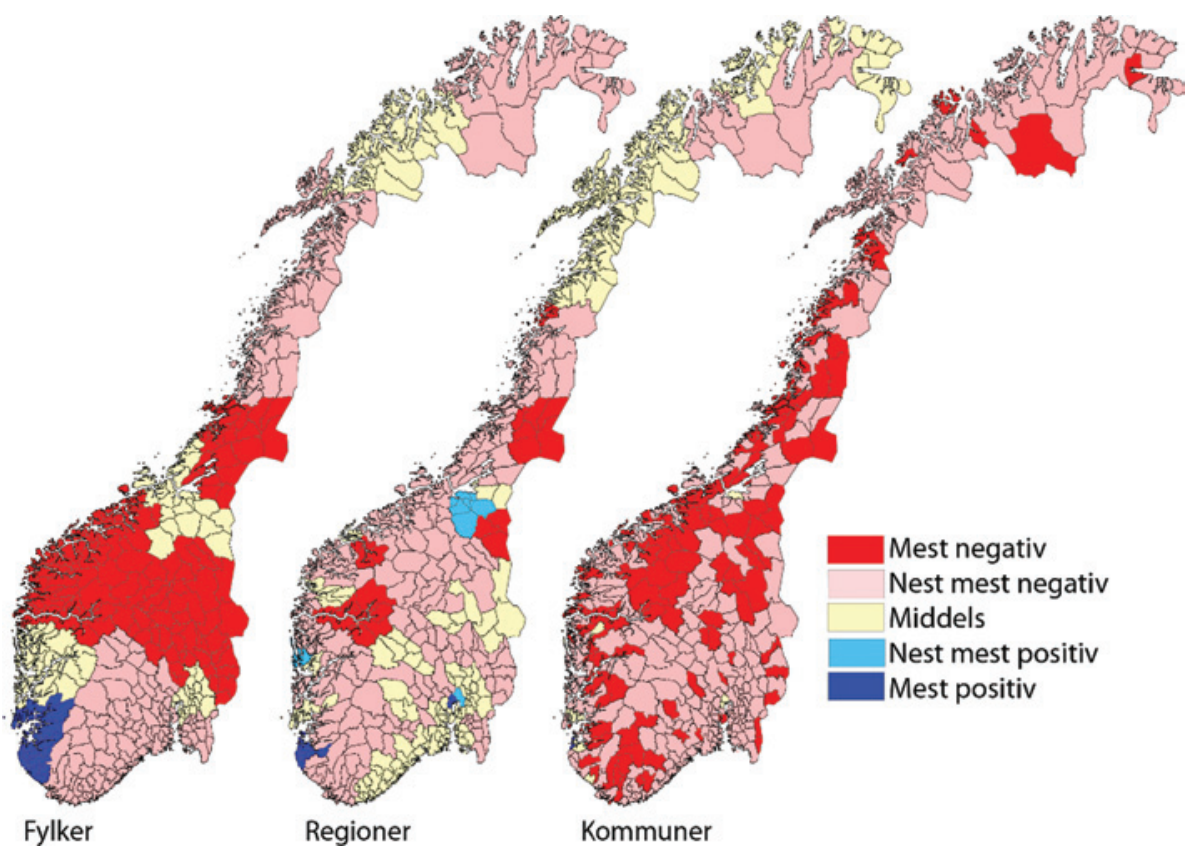

Figur 3.38 Bransjeeffektens variasjoner på fylkesnivå, regionnivå og kommunenivå. Skalaen er «equal interval», som betyr at stedene er delt opp i fem grupper, som igjen er oppdelt i like intervaller fra minste til største nivå. Perioden 2009-2014. 
Fylker som Oslo, Hordaland, Sør-Trøndelag og Troms har en bransjeeffekt som ligger omtrent midt mellom høyeste og laveste nivå for fylkene. Hedmark, Oppland, Sogn og Fjordane, Møre og Romsdal og Nord-Trøndelag er i gruppen med mest ugunstig bransjestruktur.

På regionnivå (i det midterste kartet) ser vi at det er svært få regioner som har hatt en gunstig næringsstruktur. Vi så i figur 3.34 at det bare var seks regioner som har hatt en næringsstruktur som tilsier at den relative veksten i næringslivet har blitt påvirket positivt. Disse regionene er de blå.

I kommunekartet ser vi at de aller fleste kommunene samler seg i de to gruppene med minst gunstig bransjestruktur. Det har dermed vært helt normalt for en kommune å ha en bransjestruktur som har bidratt til at veksten i næringslivet har vært under landsgjennomsnittet i denne perioden.

\subsubsection{Befolkningseffekten}

Noen deler av næringslivet blir påvirket av befolkningsendringer, mens andre ikke blir det. Bedrifter som hovedsakelig omsetter til et lokalt eller regionalt marked, blir mest påvirket. Det samme blir bransjer som butikkhandel, servering, personlige tjenester og bygg og anlegg. Andre bransjer, spesielt innenfor basisnæringer, antas å være helt upåvirket av befolkningsendringer på stedet.

Vi kan da beregne i hvilken grad næringslivets vekst blir påvirket av befolkningsendringer. Vi forutsetter at steder som har en befolkningsvekst som er større enn landsgjennomsnittet, vil få en tilsvarende høyere vekst i de befolkningsfølsomme bransjene.

Et sted som har en befolkningsvekst som er 10 prosent høyere enn landsgjennomsnittet, vil antas å få en arbeidsplassvekst på 10 prosent høyere enn landsgjennomsnittet i de bransjene som er befolkningsfølsomme. Det er dermed bare noen deler av næringslivet som blir berørt av befolkningsendringer på stedet.

Arbeidsplassveksten i kommunal sektor vil også bli berørt av befolkningsvekst. Steder med sterk vekst i befolkningen trenger flere ansatte i barnehager og skoler og får også større budsjettrammer som følge av økt skatteinngang og mer inntekter fra det kommunale inntektssystemet. Hele kommunal sektor er dermed en befolkningsfølsom sektor. Institusjoner i fylkeskommunal eller statlig virksomhet blir i liten grad påvirket av befolkningsvekst på stedet. Befolkningsvekstens påvirkning på kommunal sektor er forhold som vi ikke 
bruker i de historiske analysene, ettersom vi ikke analyserer veksten i offentlig sektor. Når vi skal lage scenarioer, derimot, tar vi hensyn til befolkningsendringenes effekt på kommunal virksomhet.

\subsubsection{Befolkningseffekten i fylkene}

Resultatet av utregningen av befolkningseffekten er vist i figur 3.39. Det er seks fylker som har hatt en befolkningsvekst som er høyere enn landets befolkningsvekst i denne perioden. Oslo og Akershus har hatt aller høyest befolkningseffekt av fylkene. I Oslo har befolkningseffekten ført til at veksten i antall arbeidsplasser i næringslivet ble 1,7 prosent høyere i perioden.

Fylker som Oppland, Nordland, Hedmark og Telemark har hatt sterkest negativ befolkningseffekt. I disse fylkene har arbeidsplassveksten i næringslivet blitt svekket med mer enn 2 prosent i samme periode.

I figuren har vi satt sammen bransjeeffekten og befolkningseffekten. Summen av disse to effektene blir til sammen struktureffekten. Vi ser da at Rogaland er forventet å få en arbeidsplassvekst som er 5,2 prosentpoeng høyere

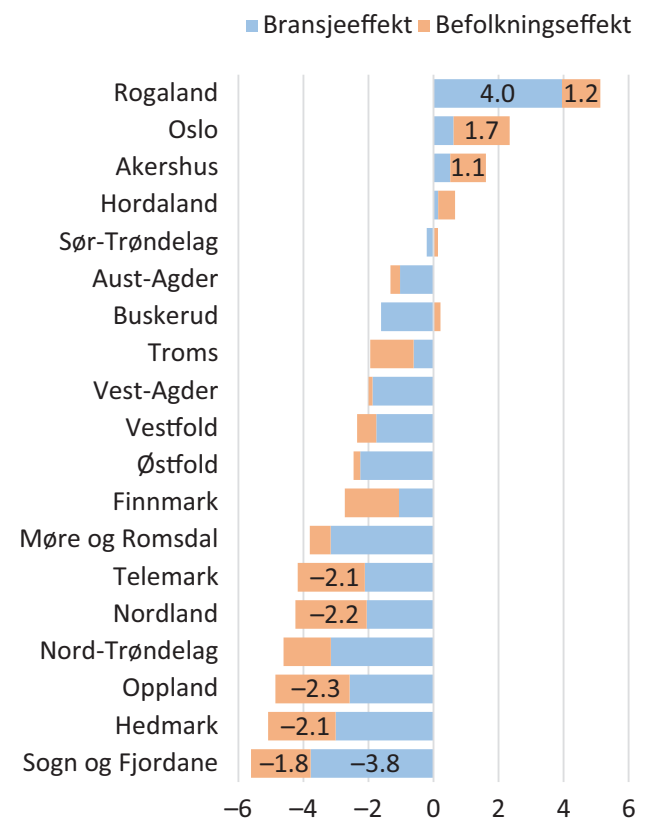

Figur 3.39 Befolkningseffekt og bransjeeffekt i fylkene. Effekten er beregnet virkning på arbeidsplassveksten i næringslivet i perioden 2009-2014. 


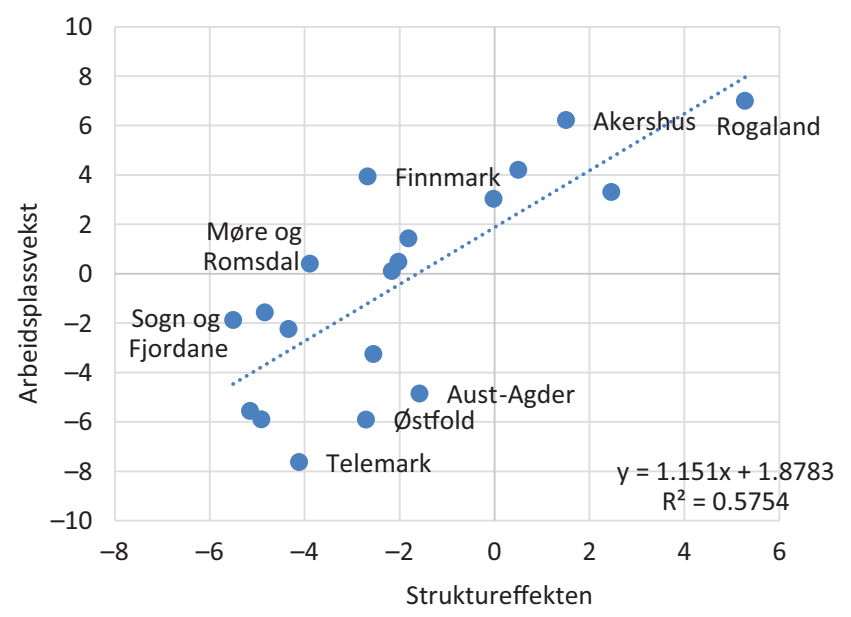

Figur 3.40 Struktureffekt, det vil si summen av bransjeeffekt og befolkningseffekt, og faktisk arbeidsplassvekst i fylkene i perioden 2009-2014.

enn landsgjennomsnittet i perioden. Sogn og Fjordane, som har de mest ugunstige strukturelle forholdene, er forventet å få 5,4 prosentpoeng lavere arbeidsplassvekst enn landsgjennomsnittet.

I figur 3.40 har vi plottet inn struktureffekten og arbeidsplassveksten i fylkene. $\mathrm{R}^{2}$ har nå økt til 0,5754 . Det er litt mer enn vi fikk da vi bare hadde med bransjeeffekten, i figur 3.33. Det som er mer tilfredsstillende, er at betaverdien for struktureffekten nå er 1,151. Ideelt sett burde denne være 1,0, men avviket har blitt mye mindre enn når vi bare hadde med bransjeeffekten. Vi ser av figur 3.39 at de fylkene som hadde den mest positive bransjeeffekten, også hadde høyest befolkningsvekst, samtidig som at fylkene med mest negativ bransjestruktur hadde den laveste befolkningseffekten. Det er dermed en klar positiv korrelasjon mellom bransje- og befolkningseffekten. Denne positive korrelasjonen kan ha blitt skapt gjennom at fylker med en gunstig bransjestruktur først har fått høyere innflytting som følge av sterkere arbeidsplassvekst. Dermed har befolkningsveksten blitt høyere, noe som igjen har gitt ringvirkninger i form av ekstra vekst i befolkningsfølsomme bransjer.

\subsubsection{Arbeidsmarkedsstørrelse}

Er det slik at størrelse også er et strukturelt trekk som har betydning for veksten i næringslivet? Det er en del teorier som baserer seg på at næringslivet blir 
mer produktivt i større arbeidsmarkeder. Da vil kanskje også større arbeidsmarkeder oppnå sterkere vekst enn små? I så fall vil arbeidsmarkedets størrelse være en strukturell faktor som vi burde få inn i modellen.

Vi skal teste denne hypotesen med empiriske data. Vi bruker da regionnivået, og Norge er delt opp i 84 regioner.

I figur 3.41 ser vi sammenhengen mellom arbeidsplassvekst og størrelse i 84 regioner i Norge i perioden 2009-2014. Store regioner har systematisk høyere arbeidsplassvekst enn små, selv om det er ganske stor spredning. Ut fra en slik enkel tofaktor-analyse kan det se ut til at regionens størrelse har betydning for arbeidsplassveksten.

I figur 3.42 ser vi ikke på arbeidsplassveksten direkte, men på avviket mellom forventet arbeidsplassvekst ut fra struktureffekten og den faktiske arbeidsplassveksten. Da forsvinner den positive sammenhengen helt. Sammenhengen er nå faktisk negativ, men så svak at det er mer riktig å si at det ikke synes å være noen sammenheng.

Det betyr at den positive sammenhengen mellom regionstørrelse og vekst vi så i den øverste figuren, er spuriøs. Store regioner har systematisk mer gunstig bransjestruktur og høyere befolkningsvekst, og det er det som skaper den økte veksten.

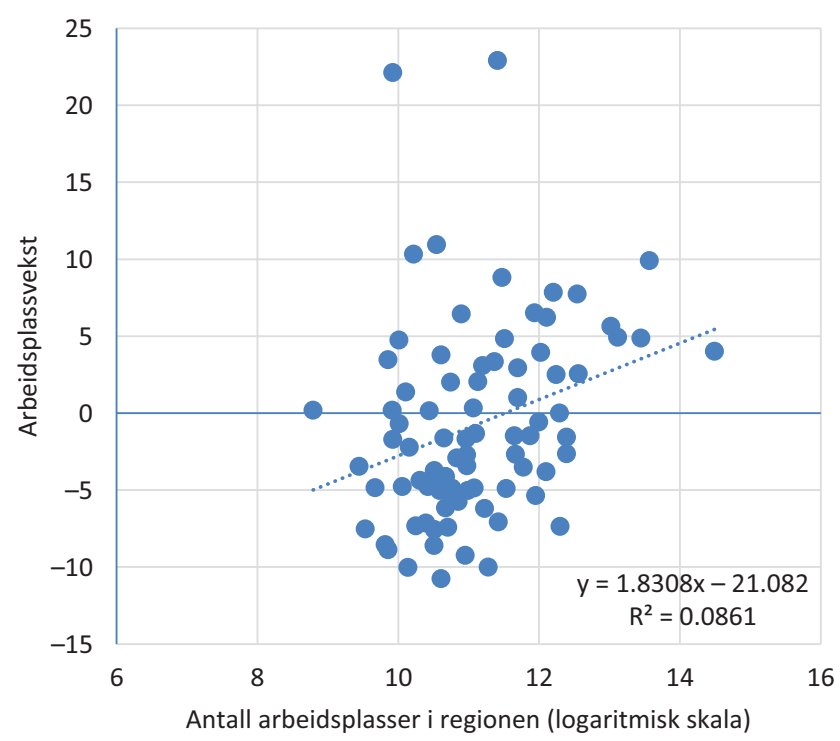

Figur 3.41 Størrelse i antall arbeidsplasser og arbeidsplassvekst i 84 regioner i perioden 2009-2014. 


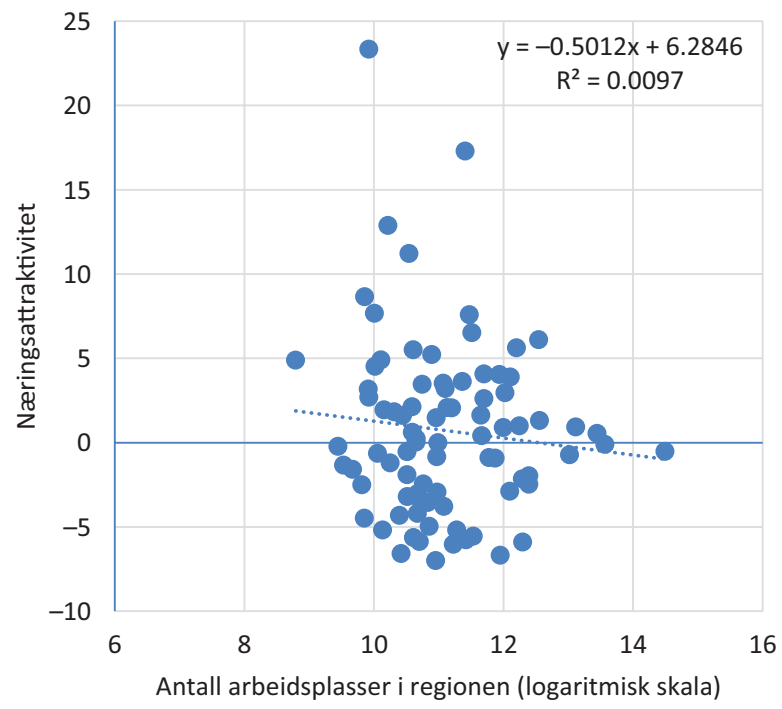

Figur 3.42 Sammenhengen mellom arbeidsmarkedsstørrelse og næringsattraktivitet. Næringsattraktivitet målt som avvik mellom forventet arbeidsplassvekst ut fra struktureffekt og faktisk arbeidsplassvekst.

\subsection{Samlet struktureffekt}

Vi har så langt vist hvordan strukturelle drivkrefter påvirker flytting og arbeidsplassvekst i næringslivet. Folkerike kommuner med høy arbeidsmarkedsintegrasjon trekker til seg innflyttere på bekostning av små og isolerte kommuner, selv om alt annet er likt. Bransjestrukturen har en sterk innflytelse på arbeidsplassveksten i næringslivet. Vi har også sett hvordan arbeidsplassveksten påvirker flyttingen, og på hvilken måte befolkningsveksten påvirker næringsutviklingen.

Vi har dermed ett sett med strukturelle drivkrefter for arbeidsplassveksten, og et annet sett med strukturelle drivkrefter som påvirker flyttingen. I figur 3.43 har vi plottet verdiene for kommunene inn i samme diagram.

Skalaen for struktur flytting er innflytting i prosent av folketallet. Det vil si at Skedsmo er forventet å få en relativ innflytting i perioden tilsvarende 6,6 prosent av folketallet. Utsira er forventet å få en relativ utflytting på 4,2 prosent av folketallet.

Verdiene for struktur næringsliv er skalert slik at den korresponderer med effekten på flytting. Det vil si at Sola er forventet å ha en relativ arbeidsplassvekst i næringslivet i perioden som korresponderer med en økt innflytting på 


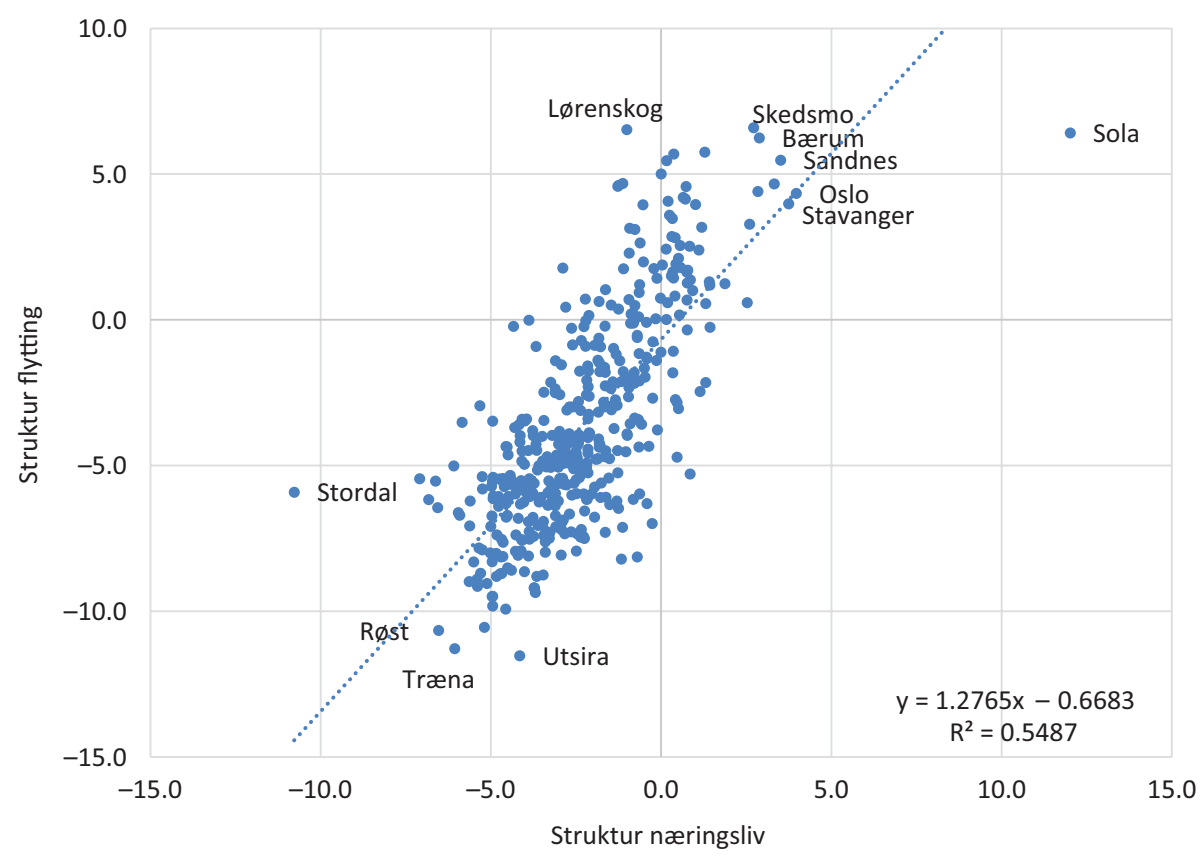

Figur 3.43 Strukturelle drivkrefter for flytting og strukturelle drivkrefter for arbeidsplassvekst i næringsliv i perioden 2000-2015.

12,o prosent av folketallet. Stordal, som har den minst gunstige bransjestrukturen, er forventet å ha en relativ arbeidsplassnedgang i næringslivet som statistisk sett er forventet å skape økt utflytting tilsvarende 10,8 prosent av folketallet.

Et slånde trekk i figuren er at de strukturelle betingelsene for arbeidsplassvekst og flytting er sterkt korrelert. Stedene med de beste betingelsene for å få netto innflytting har også den gunstigste bransjestrukturen. De strukturelle flyttefaktorene er tilsynelatende konstante over tid. Effekten av bransjestrukturen kan imidlertid endres ganske mye. Sola har den minst gunstige bransjestrukturen i enkeltåret 2015.

På forrige side så vi at de strukturelle drivkreftene som påvirker flyttingen, og de strukturelle drivkreftene som påvirker arbeidsplassutviklingen i næringslivet, er ganske sterkt korrelert i kommunene. På kartene i figur 3.44 kan vi se disse regionale mønstrene. Kommunene rundt Oslofjorden har positive strukturelle flyttefaktorer som påvirker nettoflyttingen positivt, samtidig med at de samme kommunene også har gunstige strukturelle betingelser for å få arbeidsplassvekst i næringslivet. De strukturelle betingelsene for arbeidsplassvekst i næringslivet 


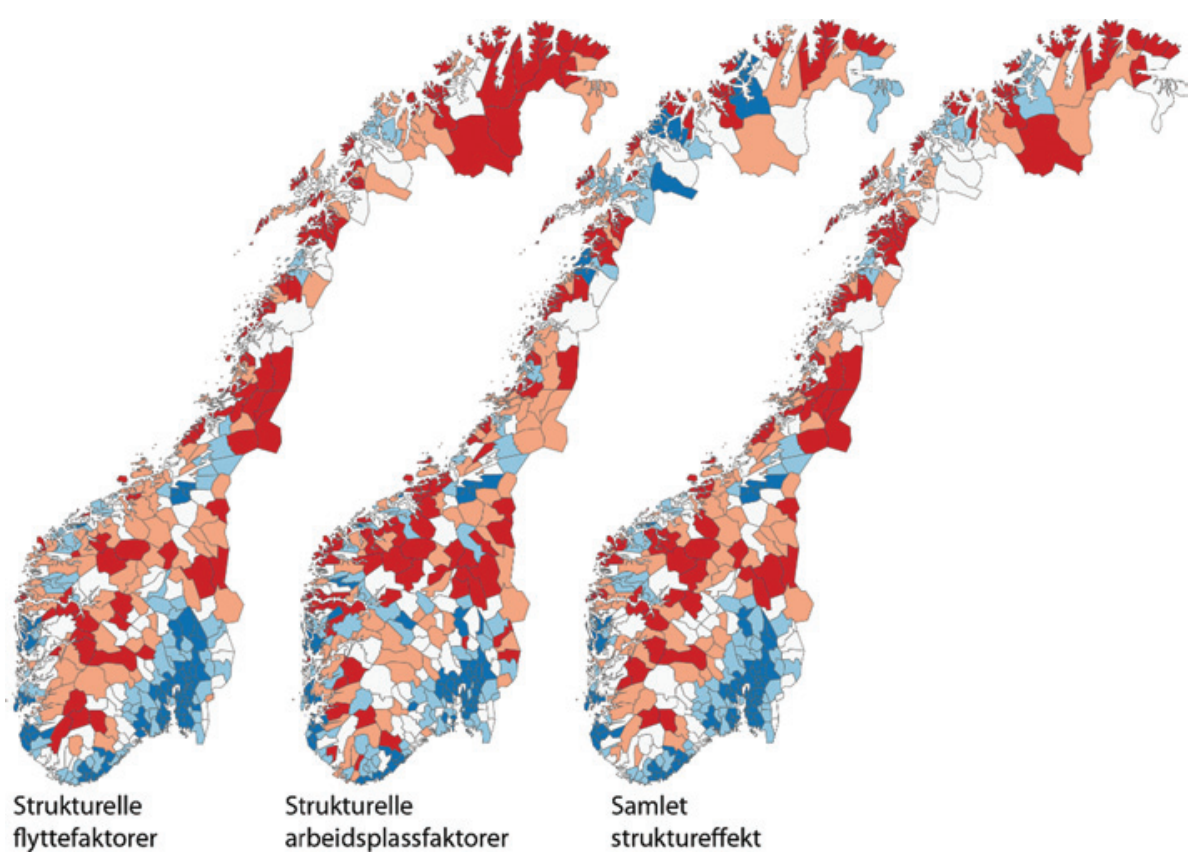

Figur 3.44 Strukturelle flyttefaktorer, strukturelle arbeidsplassfaktorer (for næringslivet) og samlet struktureffekt for kommunene i perioden 2002-2015.

er noe mindre sentraliserende enn de strukturelle flyttefaktorene. Det er noen kommuner i distriktene som har hatt relativt gunstige forhold for å få arbeidsplassvekst i næringslivet, men det overordnede mønsteret er likevel klart sentraliserende.

Kartet helt til høyre i figur 3.44 viser den samlede struktureffekten. Dette er den statistisk forventede nettoflyttingen til den enkelte kommune. Kartet viser tydelig hvilke sterke sentraliserende drivkrefter som har virket etter 2000.

Heldigvis er det mange kommuner som har en annen utvikling enn den statistisk forventede utviklingen. Det ser vi når vi sammenlikner forventet utvikling med den faktiske. Hvis vi hadde en modell som forklarte steders vekst med 100 prosents nøyaktighet ut fra strukturelle forhold, ville det ikke ha noen hensikt å drive med lokale eller regionale utviklingsstrategier, fordi utviklingen var forutbestemt av de strukturelle betingelsene. Når vi ser at noen kommuner har betydelig sterkere vekst enn de strukturelle betingelsene skulle tilsi, kan vi ha et mer optimistisk syn på hvilke muligheter steder har til å påvirke egen vekst. Det gjelder spesielt for enkeltkommuner eller 
enkeltregioner. Når det gjelder mulighetene til å stanse sentraliseringen, gir modellen små muligheter. Sentraliseringen vil fortsette så lenge de strukturelle drivkreftene fortsetter å virke. De 100 minst sentrale kommunene vil med nesten 100 prosent sannsynlighet få svakere vekst enn de 100 mest sentrale. Men en enkelt kommune i distriktene har en mulighet til å påvirke egen vekst i positiv retning. Det er derfor avvikene mellom faktisk vekst og forventet vekst er spesielt interessante. Det er nettopp disse avvikene vi bruker som indikator for det vi kaller attraktivitet. 



\section{KAPITTEL 4}

\section{Attraktivitet}

Vi har så langt beskrevet hvordan vi har bygget opp en modell som skal regne ut forventet arbeidsplassvekst i næringslivet og forventet nettoflytting i kommuner, regioner og fylker. Den forventede veksten som modellen regner ut, kan vi da sammenlikne med den faktiske arbeidsplassveksten på et sted. Vi bruker avviket mellom faktisk og forventet vekst som indikator for næringsattraktivitet. På samme måte bruker vi avviket mellom faktisk og forventet nettoflytting som mål for bostedsattraktivitet. Mesteparten av arbeidet med å lage indikatorer for attraktivitet består da i å lage en modell for normal eller forventet utvikling. Logikken er at noen steder har en sterkere vekst enn de strukturelle forholdene tilsier, og at dette er et resultat av interne forhold på stedet.

Attraktive steder er dermed steder som har oppnådd høyere vekst enn det de strukturelle forholdene skulle tilsi. Det er nettopp det som er målet for lokal og regional næringsutvikling og stedsutvikling. De fleste kommuner, regioner og fylker forsøker å stimulere til sterkere vekst. De er klar over at betingelsene for vekst varierer fra sted til sted, men forsøker etter beste evne å påvirke veksten på ulike måter. Hvis et sted lykkes, vil resultatet være at veksten blir høyere enn forventet.

\subsection{Attraktivitetsmodellen for arbeidsplassvekst}

Vi har isolert to strukturelle forhold som påvirker arbeidsplassveksten i næringslivet signifikant. Det er struktureffekten og befolkningseffekten. Størrelsen på arbeidsmarkedet ser ikke ut til å påvirke arbeidsplassveksten direkte. Vi har tidligere forsøkt å teste om det å ha tilgang til distriktspolitiske virkemidler har effekt på arbeidsplassveksten i næringslivet, men vi har ikke funnet noen slik effekt. Vi har heller ikke funnet at områder med høgskoler eller høy andel med høy utdanning blant sysselsatte har systematisk bedre arbeidsplassvekst. Hvis en ser på korrelasjonen mellom arbeidsplassvekst og arbeidsmarkedsstørrelse 
eller kompetansenivå uten å korrigere for bransjestruktur og befolkningsvekst, er det en signifikant sammenheng. Denne sammenhengen ser imidlertid ut til å være spuriøs, for så snart vi korrigerer for bransjestruktur og befolkningsvekst, forsvinner disse sammenhengene.

\subsubsection{Visuell framstilling av arbeidsplassmodellen}

I figur 4.1 skal vi forsøkeå gi en grafisk framstilling av modellen for arbeidsplassvekst i næringslivet.

Denne modellen er laget for å avdekke de viktigste drivkreftene for vekst $\mathrm{i}$ næringslivet i et område. Modellen sier at næringslivet i et område blir påvirket av tre strukturelle drivkrefter: det nasjonale bidraget, bransjeeffekten og befolkningsveksten i området.

Den nasjonale veksten er veksten i næringslivet i Norge i den perioden vi studerer. Dersom det er oppgangskonjunktur og næringslivet i Norge vokser, er dette bidraget positivt for alle steder: Vokser næringslivet i Norge med 2 prosent i perioden, er dette bidraget 2 prosent for alle steder.
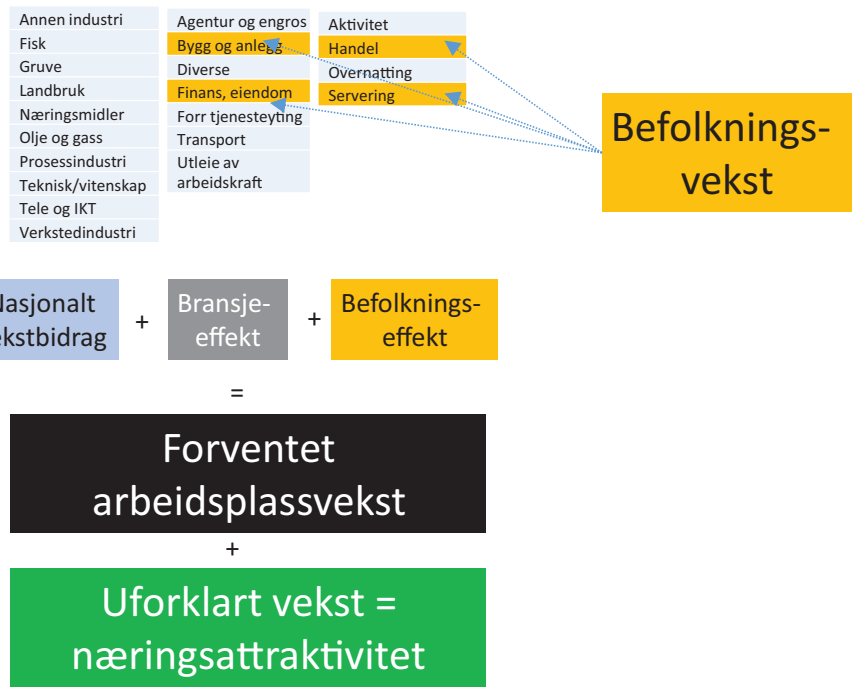

$=$

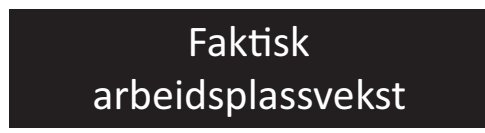

Figur 4.1 Grafisk framstilling av modell for arbeidsplassvekst i næringslivet. 
Bransjeeffekten avhenger av hvordan næringslivet er sammensatt i ulike bransjer. For vårt formål har vi delt opp næringslivet i 23 ulike bransjer. Steder med en stor andel av arbeidsplasser i bransjer med vekst vil få et positivt bidrag gjennom bransjeeffekten, mens steder med en høy andel av arbeidsplasser i bransjer med nedgang vil få et negativt bidrag.

Befolkningseffekten virker slik at steder med over gjennomsnittlig befolkningsvekst får et ekstra stimuli til arbeidsplassvekst i bransjer som er befolkningsfølsomme. Når vi analyserer den historiske utviklingen i næringslivet, blir modellen forenklet gjennom at befolkningsveksten opptrer som en eksogen variabel. Senere skal vi ta inn den gjensidige påvirkningen mellom arbeidsplassvekst og befolkningsvekst.

De tre strukturelle bidragene definerer hva som er forventet, eller «normal», arbeidsplassvekst i et område i en spesifikk periode. Avviket mellom den forventede arbeidsplassveksten og den faktiske vil da være en vekst som ikke er forklart av kjente strukturelle forhold. Dette avviket vil da måtte forklares av spesielle forhold på stedet, og blir en indikator for næringsattraktivitet.

\subsubsection{Næringsattraktivitet fylker}

Attraktivitet for næringsliv er definert som det som skaper avvik mellom forventet og faktisk vekst i antall arbeidsplasser i næringslivet. Den forventede veksten i antall arbeidsplasser i et område i en periode kan regnes ut gjennom en modell der antall arbeidsplasser i hver enkelt bransje på stedet, den nasjonale veksten i hver enkelt bransje og stedets befolkningsvekst er eksogene variabler.

I figur 4.2 har vi vist forventet og faktisk arbeidsplassvekst i fylkene i perioden 2009-2014. Den sorte linjen er regresjonslinjen $y=x$, den prikkede er regresjonslinjen for datapunktene, som har formen $y=1,114 \mathrm{x}+0,0346$. Regresjonslinjen for datapunktene avviker litt fra den ideelle, men ligger ganske nær. Fylker som Finnmark, Møre og Romsdal, Akershus og Sogn og Fjordane har hatt en faktisk arbeidsplassvekst i perioden som er høyere enn den forventede. Avstanden fra datapunktet i figuren og den sorte linjen er næringsattraktiviteten. Fylker som Aust-Agder, Telemark og Østfold har størst negativt avvik.

Figur 4.3 illustrerer det samme, men nå er forventet arbeidsplassvekst splittet opp i nasjonalt bidrag, bransjeeffekt og befolkningseffekt. De grønne søylene viser næringsattraktiviteten. 


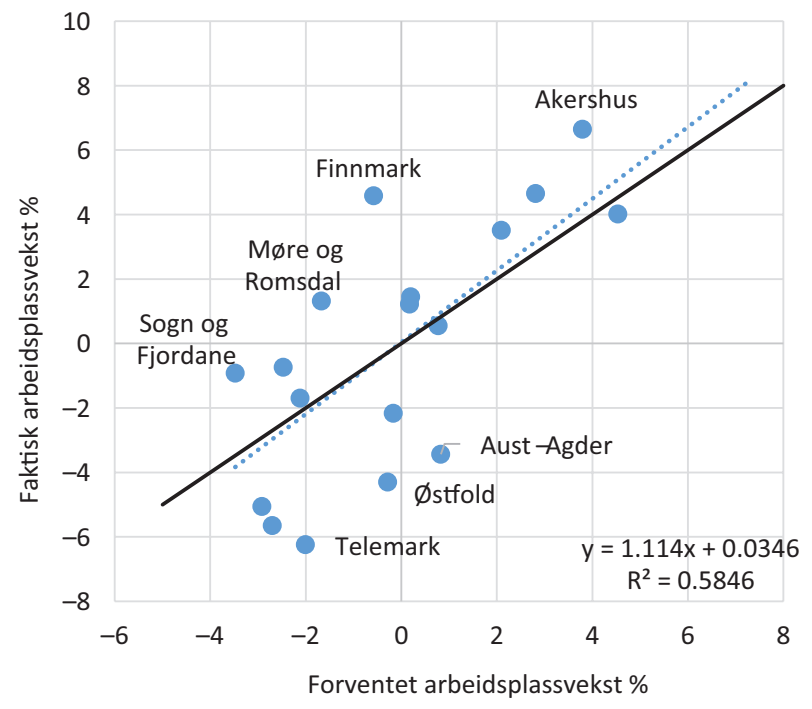

Figur 4.2 Forventet og faktisk arbeidsplassvekst i næringslivet i fylkene i perioden 2009-2014.

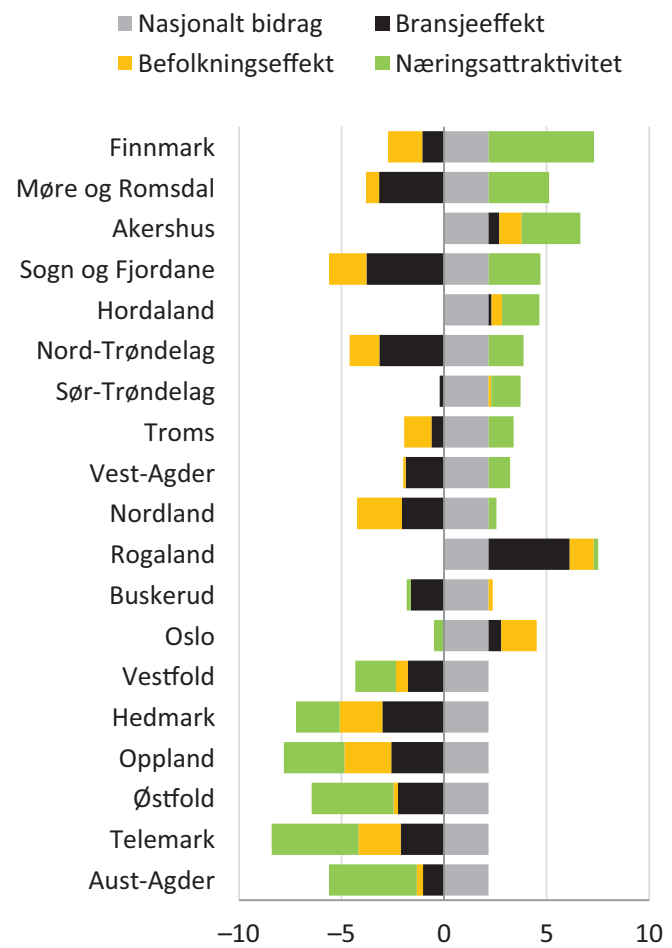

Figur 4.3 Prosentvis arbeidsplassvekst, dekomponert i ulike strukturelle drivkrefter og attraktivitet i perioden 2009-2014. 
Vi kan se at Rogaland, som har hatt den sterkeste veksten, har en arbeidsplassvekst som ligger svært tett opp til forventet arbeidsplassvekst. Oslo har også hatt en vekst tett opp til forventet.

Finnmark, Møre og Romsdal og Akershus er de fylkene som har hatt størst positivt avvik mellom faktisk og forventet vekst. Aust-Agder, Telemark og Østfold har hatt størst negativt avvik.

\subsubsection{Næringsattraktivitet regioner}

Vi kan også se på forventet og faktisk arbeidsplassvekst i næringslivet i regionene, som vist i figur 4.4. Fire regioner har hatt spesielt mye høyere arbeidsplassvekst enn forventet i årene etter 2008. Det er Hitra/Frøya, Hordaland Vest, Voss og Øst-Finnmark. Regionene med størst avvik er dermed regioner hvor avviket er positivt. Kanskje er det slik at regioner med sterk nedgang setter i verk kompenserende tiltak, eller får statlige midler til omstilling. Regioner med sterk vekst har ingen grunn til å begrense veksten.

Når vi ser lista over regionene med høyest næringsattraktivitet i figur 4.5, er det naturlig å spørre seg hva som er årsaken til at disse har det. Høy næringsattraktivitet kan ha mange ulike forklaringer.

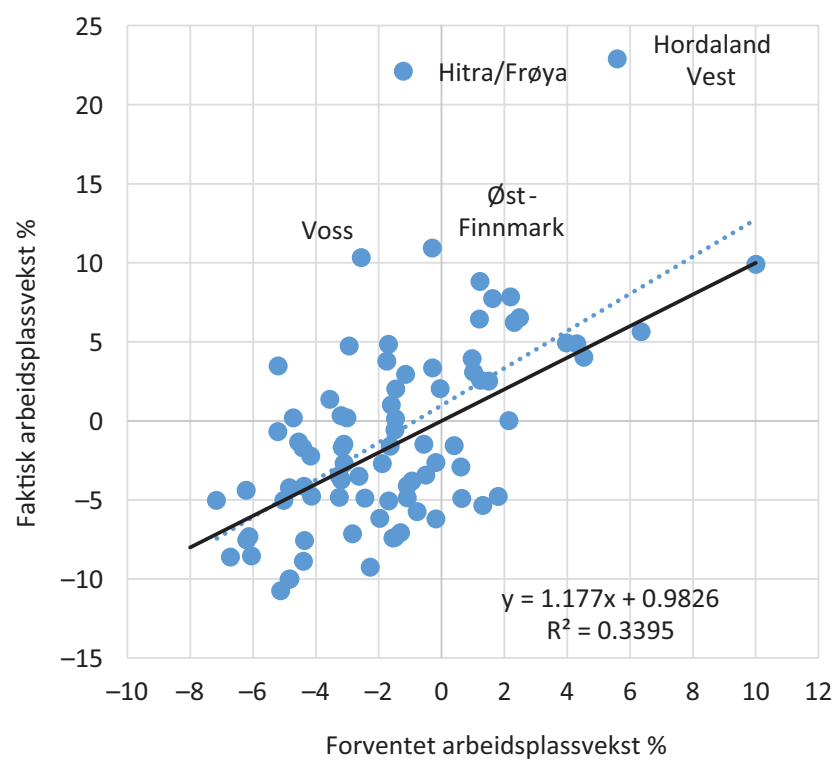

Figur 4.4 Forventet og faktisk arbeidsplassvekst i næringslivet i regionene i perioden 2009-2014. 


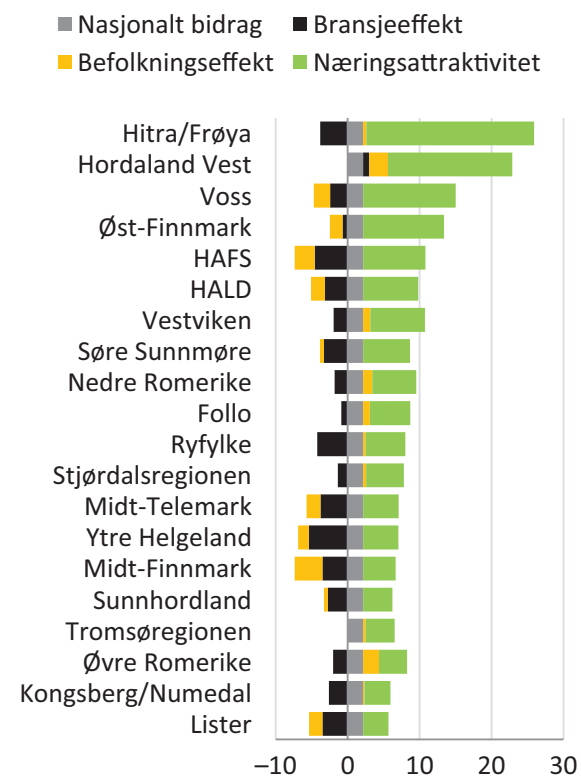

Figur 4.5 Prosentvis arbeidsplassvekst, dekomponert i ulike strukturelle drivkrefter og attraktivitet i perioden 2009-2014.

Noen steder med sterk vekst har en hjørnesteinsbedrift som vokser kraftig, og som kan være hele forklaringen på at stedet får en samlet vekst som er sterkere enn forventet. Vi kan kalle dette for lokomotivdrevet vekst.

På andre steder kan det være infrastruktur i form av attraktive næringsområder. Opprettelsen av oljebaser er et eksempel på slike områder som trekker til seg mange bedrifter. Flyplasser kan også tenkes å virke på samme måte.

Sterk vekst kan også være knyttet til en klynge av bedrifter, som har en gjensidig positiv påvirkning på hverandre. Hvis vi kunne avdekke steder som har hatt en generell sterk vekst i mange bedrifter og bransjer samtidig, og hvor dette kunne knyttes til lokal eller regional næringspolitikk, ville det være spesielt interessant. Da kunne vi forsøke å avdekke hvilke grep som ble gjort, og lære av det.

De statistiske analysene kan identifisere steder med unormalt sterk vekst, men for å finne ut av årsakene må vi gå dypere inn i materien og avdekke hvilke bedrifter og bransjer som har drevet fram veksten, og dernest finne ut av årsakene til dette. 


\subsubsection{Næringsattraktivitet kommuner}

I figur 4.6 ser vi et plott med forventet og faktisk arbeidsplassvekst i kommunene i Norge. Et problem med analyser på kommunenivå er at det er mange svært små kommuner med få arbeidsplasser i næringslivet. For slike små kommuner blir det fort store prosentvise avvik. I figurene har vi derfor tatt bort de 100 minste kommunene.

Vi kan se at det blir stadig større spredning i plottene når vi bruker mindre geografiske enheter. $\mathrm{R}^{2}$ for plottet for fylker var 0,58 . For regioner var $\mathrm{R}^{2} 0,34$. I dette kommuneplottet har $\mathrm{R}^{2}$ sunket til 0,24. Det kan bety at tilfeldige variasjoner får mer å si for kommuner. For fylker, som typisk har noen titalls kommuner, vil disse tilfeldige variasjonene jevne seg ut. En annen tolkning er at små geografiske enheter har større muligheter til å oppnå sterkere vekst gjennom å være attraktive for næringsliv enn store. En kommune har større muligheter til å oppnå en høyere vekst enn forventet enn et helt fylke.

\subsubsection{Næringsattraktivitet oppsplittet på næringstyper}

Det å splitte opp næringsattraktiviteten på de tre ulike næringstypene gir en interessant tilleggsinformasjon. Vi kan da se hvilke deler av næringslivet som

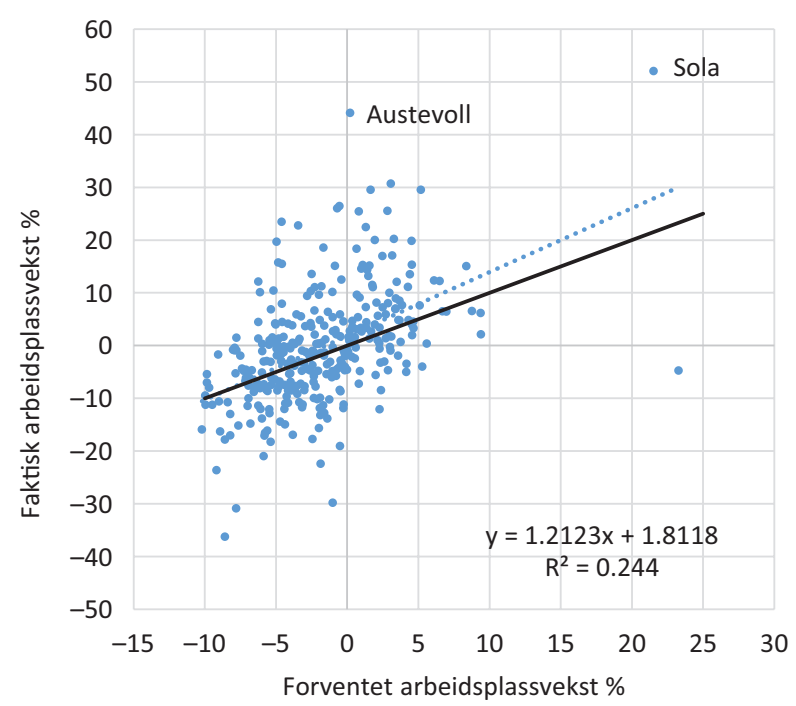

Figur 4.6 Forventet og faktisk arbeidsplassvekst i næringslivet i kommunene i perioden 2009-2014. 


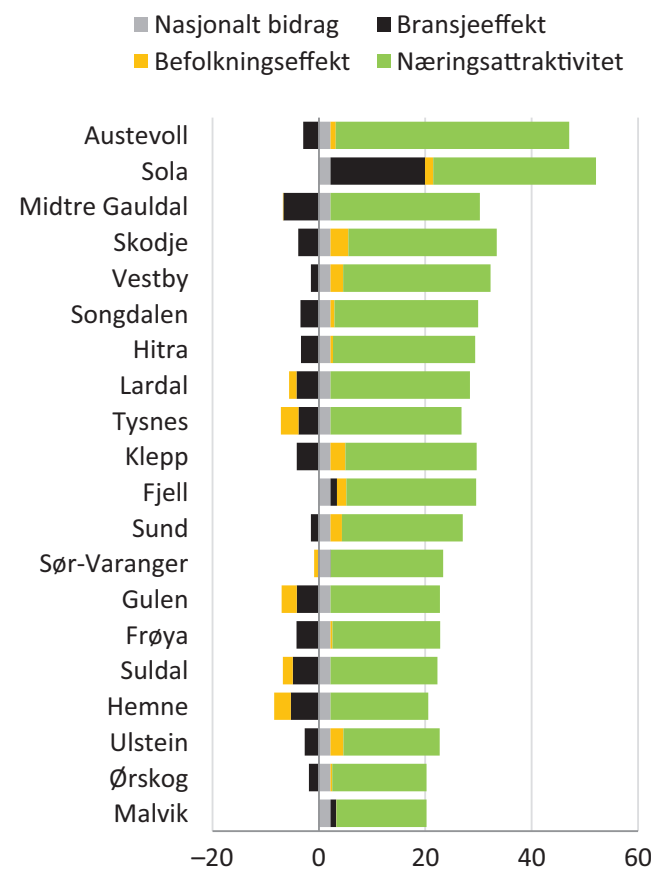

Figur 4.7 Prosentvis arbeidsplassvekst, dekomponert i ulike strukturelle drivkrefter og attraktivitet i perioden 2009-2014.

har utviklet seg bedre eller svakere enn normalt. Hvis vi ser på regionene med høyest næringsattraktivitet, som er vist i figur 4.8, ser vi at regioner som Hitra/ Frøya, Hordaland Vest, Øst-Finnmark og Kongsberg/Numedal har store deler av sin næringsattraktivitet i basisnæringene. I figur 4.9 ser vi at de seks kommunene med høyest næringsattraktivitet alle hadde store deler av sin næringsattraktivitet i basisnæringene.

Et annet trekk vi kan se, er at det er få kommuner og regioner hvor besøksnæringene har hatt stor betydning. Besøksnæringene endrer seg sjelden i store sprang. Det kan kanskje være fordi typiske hjørnesteinsbedrifter ofte er i basisnæringene, spesielt industri. I besøksnæringene er det ofte mange små bedrifter. Det kan også være at dersom en besøksbedrift (butikk, hotell eller restaurant) i en typisk besøkskommune blir lagt ned, vil det ofte dukke opp en ny bedrift som overtar kundegrunnlaget. Når en industribedrift blir lagt ned, er dette oftere permanent. Det gir en større stabilitet i besøksnæringene, mens basisnæringene blir mindre stabile. Det er ikke sikkert at dette betyr at besøksattraktivitet er mindre viktig. Kanskje økt besøksattraktivitet er mer varig? 


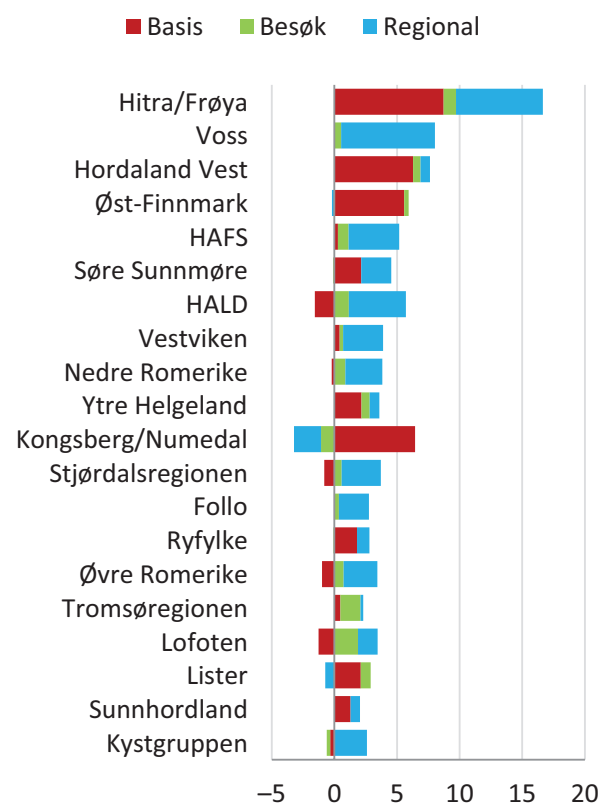

Figur 4.8 Næringsattraktivitet i regioner oppsplittet i tre næringstyper. Enheten er prosentvis andel av samlet sysselsetting.

Det vi også ser tydelig av diagrammene, er at utviklingen i de regionale næringene er svært viktig for den samlede næringsattraktiviteten. De regionale næringene består av bransjer som er ganske anonyme når det er snakk om næringsutvikling. Det er ofte snakk om basisnæringene og besøksnæringene, fordi dette er næringer som bringer inn kapital. De regionale næringene består av transport, bygg og anlegg, engroshandel og liknende. En kunne kanskje tenke at dette er bransjer som vokser når det er vekst i basis- og besøksnæringene. Men det er ganske svak sammenheng med utviklingen i de regionale næringene og basis- eller besøksnæringene.

\subsection{Bostedsattraktivitet}

\subsubsection{Bostedsattraktivitet kommuner}

Vi kan vise hvordan modellen avdekker de viktigste drivkreftene for variasjonen i nettoflyttingen. I kartet under viser vi hvordan arbeidsplassveksten og de strukturelle drivkreftene har påvirket nettoflyttingen, og hvordan bostedsattraktiviteten fordeles. 


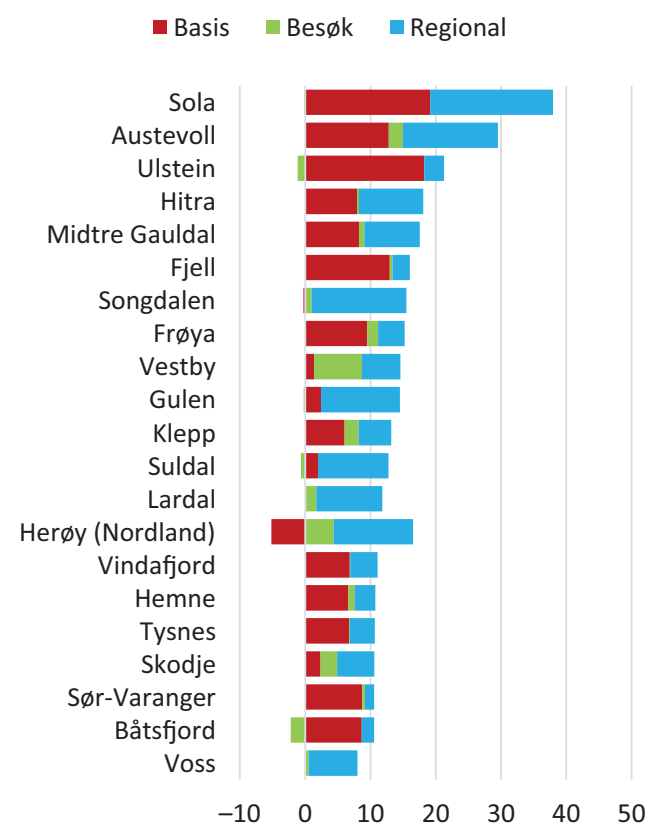

Figur 4.9 Næringsattraktivitet i kommuner oppsplittet i tre næringstyper. Enheten er prosentvis andel av samlet sysselsetting.

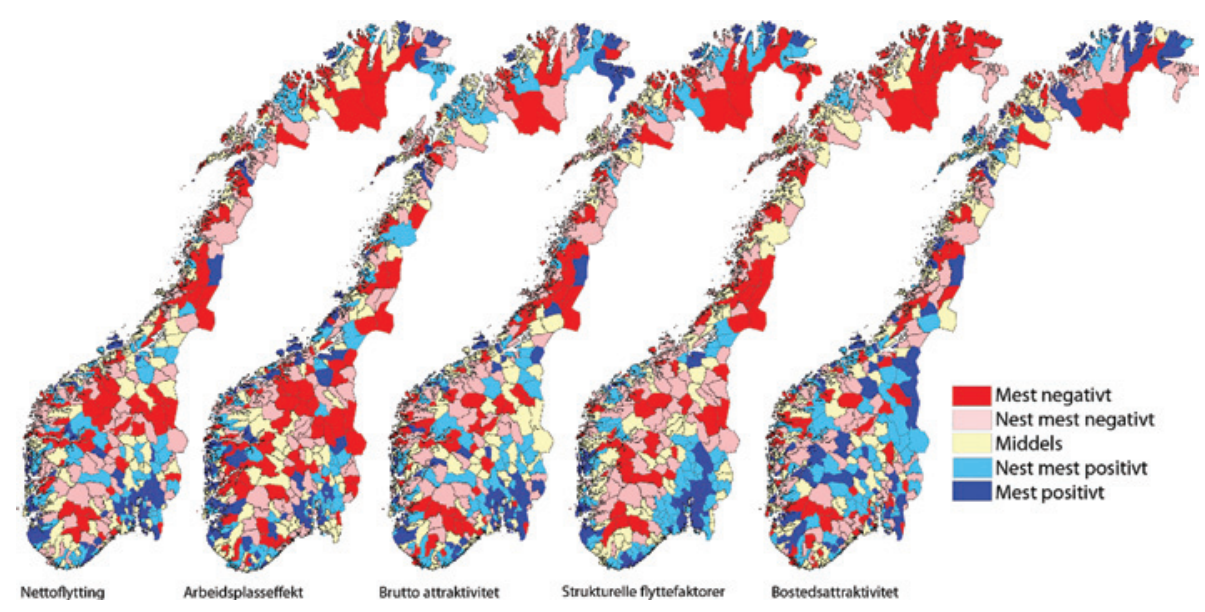

Figur 4.10 Variasjoner mellom kommunene for nettoflytting, arbeidsplassvekst, brutto attraktivitet (avvik mellom faktisk nettoflytting og forventet nettoflytting ut fra arbeidsplassveksten), strukturelle flyttefaktorer og bostedsattraktivitet. Fordelingen av kommuner er i kvantiler med like mange kommuner i hver gruppe i alle kartene. Perioden 2009-2014. 
Kartet til venstre i figur 4.10 viser variasjonene i nettoflyttingen. Mønsteret er at områdene rundt de største byene har høyest nettoflytting. Dette mønsteret er ikke helt gjennomført. Etter at arbeidsinnvandringen til Norge økte etter 2007, er det også noen typiske distriktskommuner som har hatt høy netto innflytting. Distriktskommunene har likevel i sum fortsatt lav nettoflytting sammenliknet med sentrale kommuner.

Det neste kartet viser hvilken effekt arbeidsplassutviklingen har på flyttingen. Det er et noe mindre tydelig sentrum-periferi-mønster i arbeidsplassutviklingen enn i nettoflyttingen.

Det tredje kartet viser avvik mellom faktisk nettoflytting og beregnet nettoflytting ut fra arbeidsplassveksten, betegnet som brutto attraktivitet. Det sentrale Østlandet har en tydelig konsentrasjon av kommuner som har høyere nettoflytting enn arbeidsplassveksten skulle tilsi. Det viser at det er andre drivkrefter enn arbeidsplassvekst som skaper sentraliseringen.

De strukturelle flyttefaktorene i det nest siste kartet er det som viser det klareste sentraliseringsmønsteret. Det kan tolkes som at det er forhold knyttet til lokalisering i større arbeidsmarkeder som er den sterkeste sentraliseringsdriveren.

Det siste kartet viser variasjonen i bostedsattraktiviteten, hvor bostedsattraktiviteten er beregnet som en restfaktor. Nettoflytting som ikke kan forklares verken av arbeidsplassvekst eller strukturelle faktorer, blir da brukt som en indikator for bostedsattraktivitet. Det er vanskelig å se noen klare mønstre i bostedsattraktiviteten, og det skal i prinsippet heller ikke være slike mønstre dersom vi har fanget opp de strukturelle driverne. Det er i teorien spesielle stedsspesifikke forhold som skaper denne bostedsattraktiviteten. Det kan være en vellykket lokal politikk, men det kan også være et spekter av andre årsaker.

\subsubsection{Bostedsattraktivitet i regioner}

Det er ofte lettere å se regionale mønstre når vi bruker regionnivået. Kartene i figur $4.11 \mathrm{der}$ vi bruker regioner i stedet for kommuner, viser i prinsippet det samme mønsteret. Et interessant trekk er at Oslo og naboregionene Akershus Vest, Follo og Nedre Romerike har lav bostedsattraktivitet. Det er regioner med høy netto innflytting, men den sterke arbeidsplassveksten og de gunstige strukturelle forholdene skulle ifølge modellen ha gitt enda høyere 


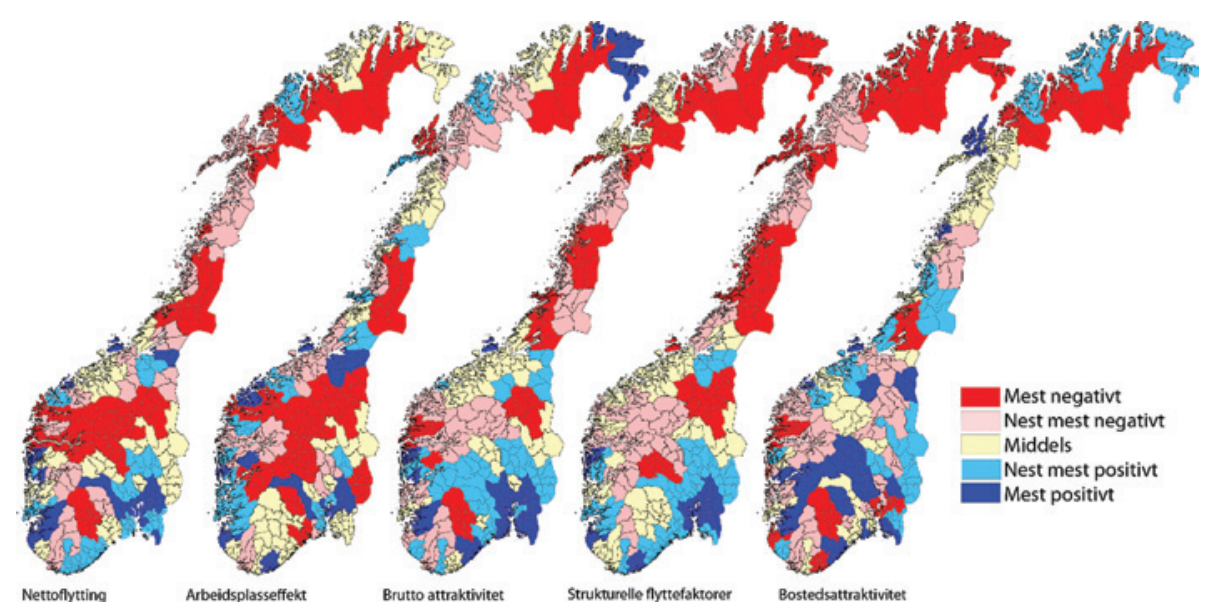

Figur 4.11 Variasjoner mellom regionene for nettoflytting, arbeidsplassvekst, brutto attraktivitet (avvik mellom faktisk nettoflytting og forventet nettoflytting ut fra arbeidsplassveksten), strukturelle flyttefaktorer og bostedsattraktivitet. Fordelingen av kommuner er i kvantiler med like mange kommuner i hver gruppe i alle kartene.

netto innflytting. I stedet har en del av regionene i omlandet til disse tre regionene fått høyere bostedsattraktivitet. Vi har gjort analyser som indikerer at dette skyldes at boligbyggingen ikke har vært høy nok i de mest sentrale områdene til at den potensielle innflyttingen har kunnet realiseres. Flyttingen har da blitt presset ut til regioner som Øvre Romerike og Østfold i stedet.

Vi kan se at det samme har skjedd i Stavangerregionen. Selve Stavangerregionen har lav bostedsattraktivitet, mens naboregionene Dalane og Ryfylke har høy bostedsattraktivitet. Det samme fenomenet finner vi i og rundt Bergen og Trondheim.

Målingene er for perioden 2009-2014. Det er en periode med historisk høy befolkningsvekst i Norge. Ifølge SSBs framskrivinger skal befolkningsveksten i Norge avta de neste årene. Det kan innebære at de sentrale pressområdene som tidligere ikke hadde tilstrekkelig boligbygging, kan realisere potensiell innflytting uten å øke boligbyggingen. I så fall vil de største byene kunne absorbere en større andel av landets befolkningsvekst. Dersom boligbyggingen har vært en flaskehals, vil flaskehalsen være stor nok til å ta unna strømmen i framtiden. Ikke fordi flaskehalsen utvides, men fordi strømmen blir mindre. 


\subsection{Samlet attraktivitet}

Hvilke kommuner og regioner har høyest samlet attraktivitet? Vi har så langt vist hvilke kommuner som har vært mest attraktive som bosted, og hvilke som er mest attraktive for næringsliv. Modellen vår er bygget opp slik at vi har tatt vekk befolkningseffekten når vi har beregnet næringsattraktiviteten, og fjernet effekten av arbeidsplassveksten når vi har beregnet bostedsattraktiviteten. Det betyr at de to attraktivitetsdimensjonene i teorien er uavhengig av hverandre. Det kan vi se når vi ser et plott med de to dimensjonene.

I plottet ser vi at de to attraktivitetsdimensjonene er uavhengige. Næringsattraktiviteten er her multiplisert med 0,27. Det er den effekten som næringsattraktiviteten har på nettoflyttingen. Samlet attraktivitet er da et mål på hvor mye befolkningsveksten er endret som følge av bosteds- og næringsattraktiviteten.

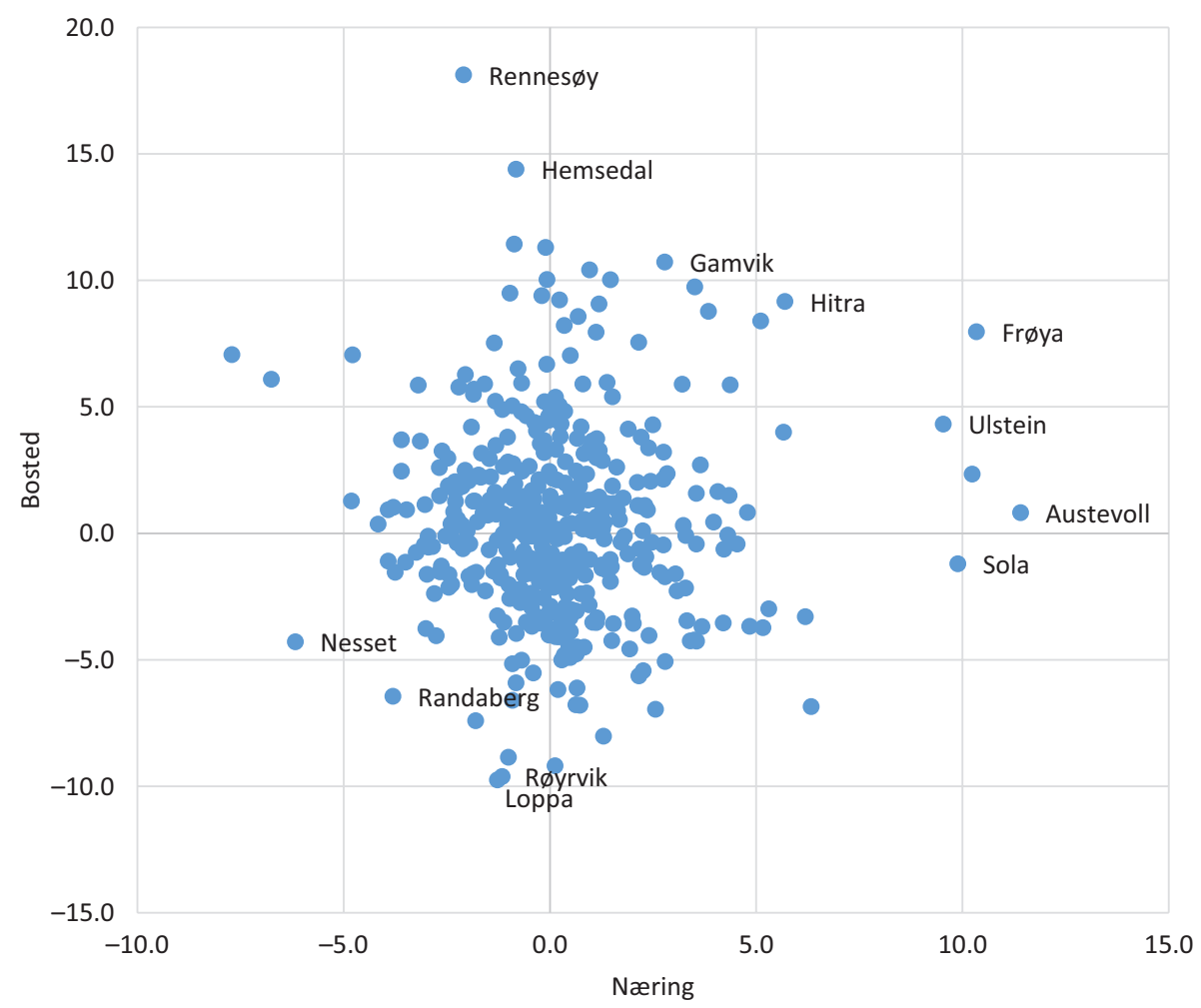

Figur 4.12 Attraktivitet for næringsliv og som bosted i norske kommuner i perioden 2006-2015. 
Noen kommuner har klart å være svært attraktive både som bosted og for næringsliv de siste ti årene. Det er kommuner som Frøya, Hitra, Ulstein og Gamvik. Andre har hatt den uheldige kombinasjonen av svak næringsattraktivitet og svak bostedsattraktivitet. Loppa, Røyrvik, Randaberg og Nesset er slike kommuner. På neste side skal vi se nærmere på de mest og minst attraktive kommunene.

\subsubsection{De mest attraktive kommunene i Norge}

I figur 4.13 ser vi lista over de mest attraktive kommunene de siste ti årene. Frøya har samlet sett vært mest attraktiv i denne perioden. Attraktiviteten for bosted er målt til 8,0. Det betyr at nettoinnflyttingen har vært 8,0 prosent høyere (av folketallet) enn de strukturelle forholdene skulle tilsi. Verdien 10,3 for næringsattraktivitet betyr at nettoflyttingen har blitt 10,3 prosent høyere som følge av at næringslivet har vokst raskere enn befolkningsveksten og bransjestrukturen skulle tilsi. Det betyr at Frøya har fått en vekst i folketallet på 18,3 prosent utover det som er forventet.

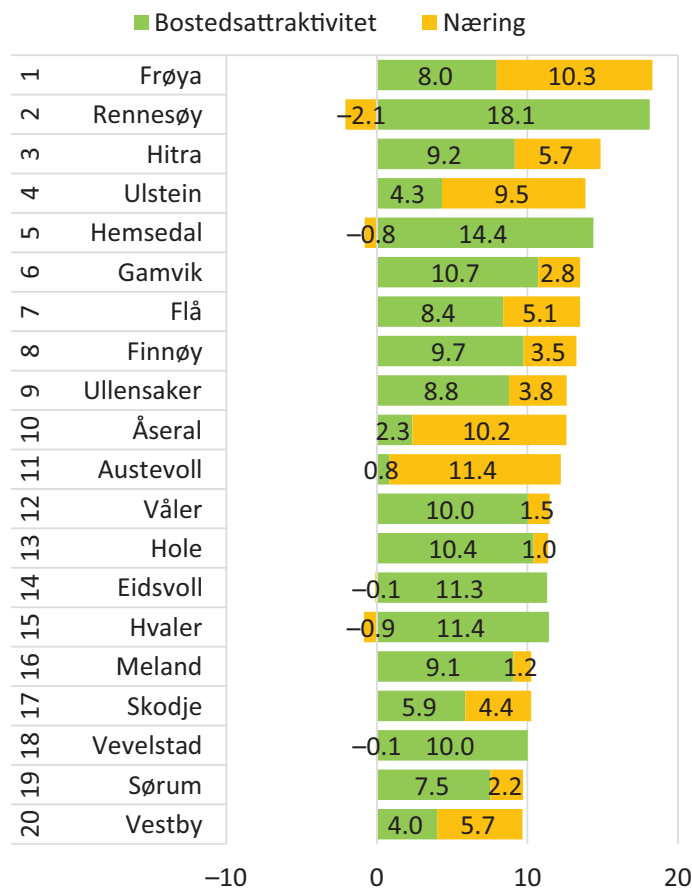

Figur 4.13 De mest attraktive kommunene i Norge i perioden 2006-2015. 


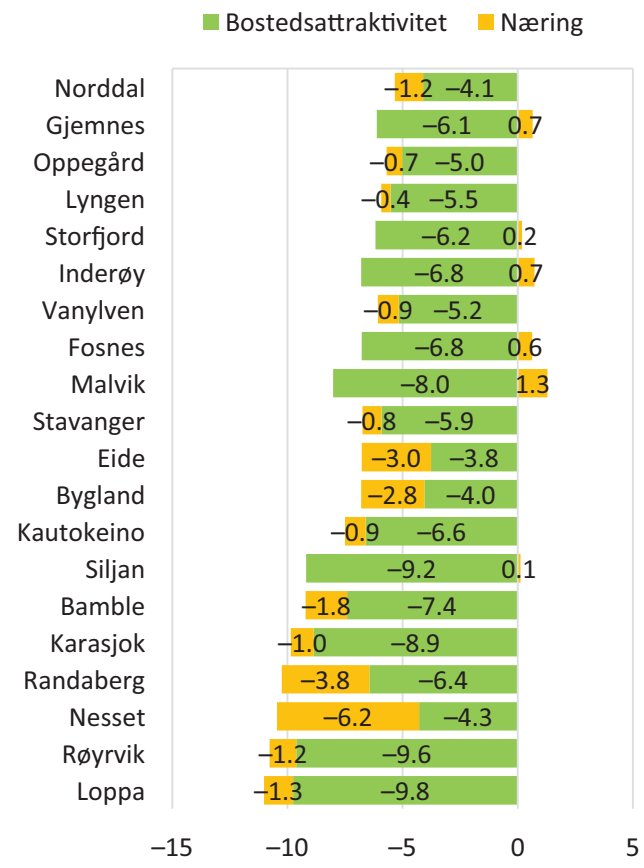

Figur 4.14 De minst attraktive kommunene i Norge i perioden 2006-2015.

I motsatt ende av skalaen finner vi Loppa kommune, som har hatt en nettoflytting som er 11,2 prosent lavere enn forventet.

I kommuner som Frøya, Austevoll, Ulstein, Vestby og Åseral er attraktiviteten hovedsakelig næringsdrevet. Rennesøy, Hemsedal og Hvaler er kommuner hvor all attraktivitet er knyttet til bosted.

Noen av kommunene på toppen av attraktivitetsbarometeret ligger i nærheten av store byer. Ullensaker, Våler (Østfold), Hole, Eidsvoll og Sørum ligger i den funksjonelle Osloregionen. Rennesøy og Finnøy ligger i Stavangerregionen. Meland og Os er lokalisert nær Bergen. For slike kommuner er det nærliggende å tenke seg at den høye bostedsattraktiviteten er knyttet til forhold i boligmarkedet. Kanskje har disse kommunene hatt bedre tilgang til boligtomter enn de andre kommunene i samme funksjonelle arbeidsmarked. Finnøy og Rennesøy er kommuner som i tillegg har fått fastlandsforbindelse i de siste årene.

Kommuner som Hemsedal, Frøya, Hitra, Flå, Træna og Austevoll er kommuner som ikke ligger i nærheten av større byer. Her er det vanskelig å tenke seg ytre forhold som skal ha ført til at akkurat disse kommunene har fått så forbausende sterk befolkningsvekst. 


\subsection{2 Østfoldsyndromet}

Samlet attraktivitet er summen av bostedsattraktivitet og næringsattraktivitet. Steder som har kombinasjonen av positiv bostedsattraktivitet og positiv næringsattraktivitet, får sterkere vekst enn de strukturelle forholdene tilsier. Steder som er lite attraktive for både næringsliv og bosetting, har svakere vekst enn normalt ut fra sine strukturelle betingelser. Steder kan imidlertid også være attraktive som bosted, men lite attraktive for næringsliv, eller attraktive for næringsliv samtidig som bostedsattraktiviteten er negativ. Vi kan se hvordan de ulike attraktivitetsdimensjonene har vært for fylkene i de ti siste årene, i figur 4.15.

Sør-Trøndelag og Møre og Romsdal er fylker som ligger i kvadranten med positiv næringsattraktivitet og positiv bostedsattraktivitet. Telemark har den uheldige kombinasjonen av lav bostedsattraktivitet og svært lav næringsattraktivitet. Østfold og Rogaland er fylker som er svært attraktive langs én av

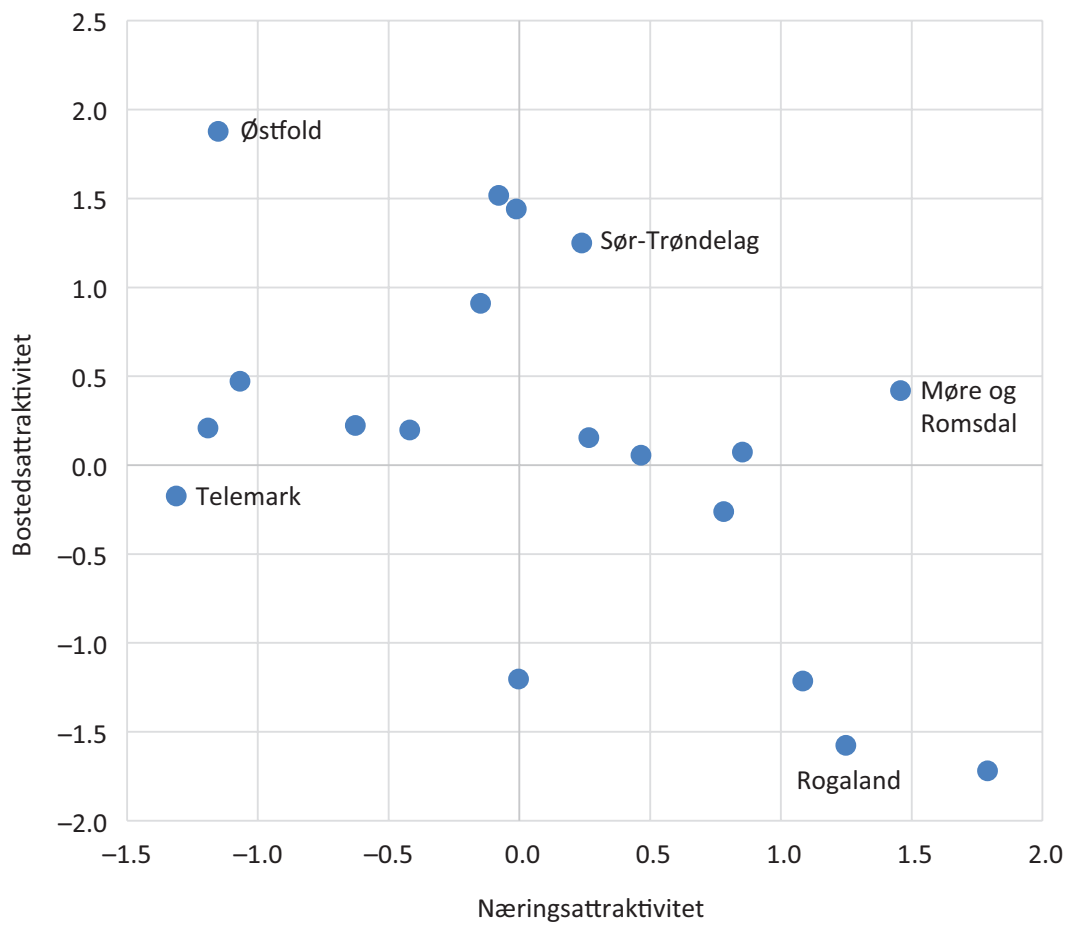

Figur 4.15 Nærings- og bostedsattraktivitet i fylkene i perioden 2005-2015. Næringsattraktiviteten er skalert slik at den gjenspeiler effekten på nettoflyttingen. 
dimensjonene, men svært lite attraktive langs den andre. Østfold har den høyeste bostedsattraktiviteten av alle fylkene, men svært negativ næringsattraktivitet. Rogaland har hatt høyest næringsattraktivitet sammen med den laveste bostedsattraktiviteten. Samlet sett er Østfold og Rogaland omtrent like attraktive.

Er det likegyldig om et sted skaper vekst gjennom bostedsattraktivitet eller gjennom næringsattraktivitet? Det kunne en kanskje tro, men vi skal vise at en slik ubalansert utvikling påvirker sysselsettingsandelen. Sysselsettingsandelen er da målt som prosentvis andel av innbyggerne som er i arbeid. Det er da likegyldig om arbeidet er i egen region, eller om det dreier seg om pendling til andre regioner.

I figur 4.16 kan vi se utviklingen av sysselsettingsandelene i Østfold og Rogaland. Da har vi målt sysselsettingsandelen i prosent av Norges sysselsettingsandel. 100 betyr at sysselsettingsandelene er lik landets. Forskjellen i utviklingen i Østfold og Rogaland er slående. Rogaland hadde i 2000 en sysselsettingsandel som var litt under landets. På slutten av 2014 var sysselsettingsandelen i Rogaland 4,7 prosent høyere enn landsgjennomsnittet.

110

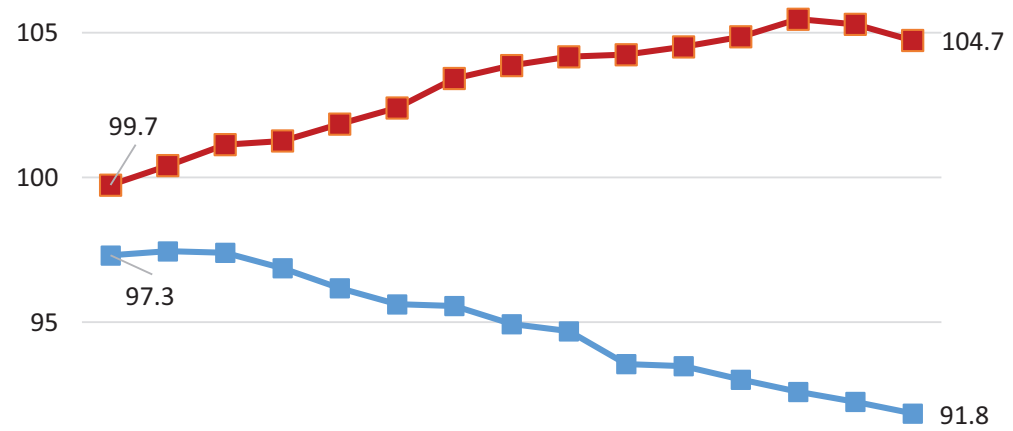

90

-

85

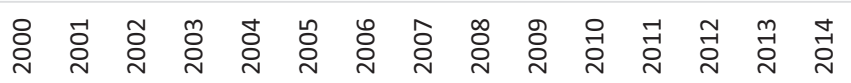

Figur 4.16 Sysselsettingsandeler i Østfold og Rogaland (antall sysselsatte i prosent av antall personer i yrkesaktiv alder) i prosent av Norges sysselsettingsandel. 
Østfold hadde i 2000 en sysselsettingsandel som var 2,7 prosent lavere enn landsgjennomsnittet, og endte opp med en andel som var 8,1 prosent lavere. I løpet av denne tiden ble Rogaland fylket med høyest sysselsettingsandel i Norge, mens Østfold fikk klart lavest sysselsettingsandel av alle fylkene.

Det virker ganske opplagt at utviklingen i Østfold ikke er bærekraftig på lang sikt. Det er egentlig bare to veier det kan gå: enten må arbeidsplassveksten ta seg opp, eller så vil innflyttingen stoppe opp. Vi kan finne flere eksempler på dette «Østfoldsyndromet» i kommuner og regioner som har kombinasjonen av høy bostedsattraktivitet og lav næringsattraktivitet. Moralen er at det er viktig å ha en balansert utvikling, og ikke vokse på bostedsattraktivitet alene.

Steder som vokser utelukkende på næringsattraktivitet, får i regelen høyere sysselsettingsandeler. Det er ikke så lett å se problemer med det. Men slike steder har gått glipp av muligheten til økt innflytting og befolkningsvekst.

\subsubsection{Hell og attraktivitet}

Det at en kommune har gunstige strukturelle forhold for vekst, kan vi kalle hell. Det innebærer at kommunen har en gunstig lokalisering for å få innflytting, og at kommunen har et næringsliv som er konsentrert til vekstbransjer. Attraktiviteten til kommunen er et mål for om veksten har vært over eller under forventet verdi. Forventet verdi er da knyttet til de strukturelle forholdene. I figur 4,17 kan vi vise hvordan norske kommuners befolkningsvekst er knyttet til henholdsvis struktur (hell) og attraktivitet (dyktighet?).

I figuren ser vi at kommunene kan deles inn i fire kvadrater. I det øverste høyre kvadratet finner vi kommuner som har gunstige strukturelle forhold, og som samtidig har vært attraktive. Sola, Ullensaker og Ås er de mest typiske representantene for denne kategorien. De har de beste betingelsene og har samtidig overprestert når det gjelder innflytting. Det er slike kommuner som har høyest vekst. Det er både heldige og attraktive.

Nede til høyre finner vi kommuner som har svært gode strukturelle betingelser for befolkningsvekst, men som har fått mye lavere vekst enn forventet. Randaberg, Stavanger og Oppegård er de mest typiske representantene. Det er kommuner som en i utgangspunktet hadde forventet å ha høyest innflytting, men som ikke har fått den befolkningsveksten en forventet. 


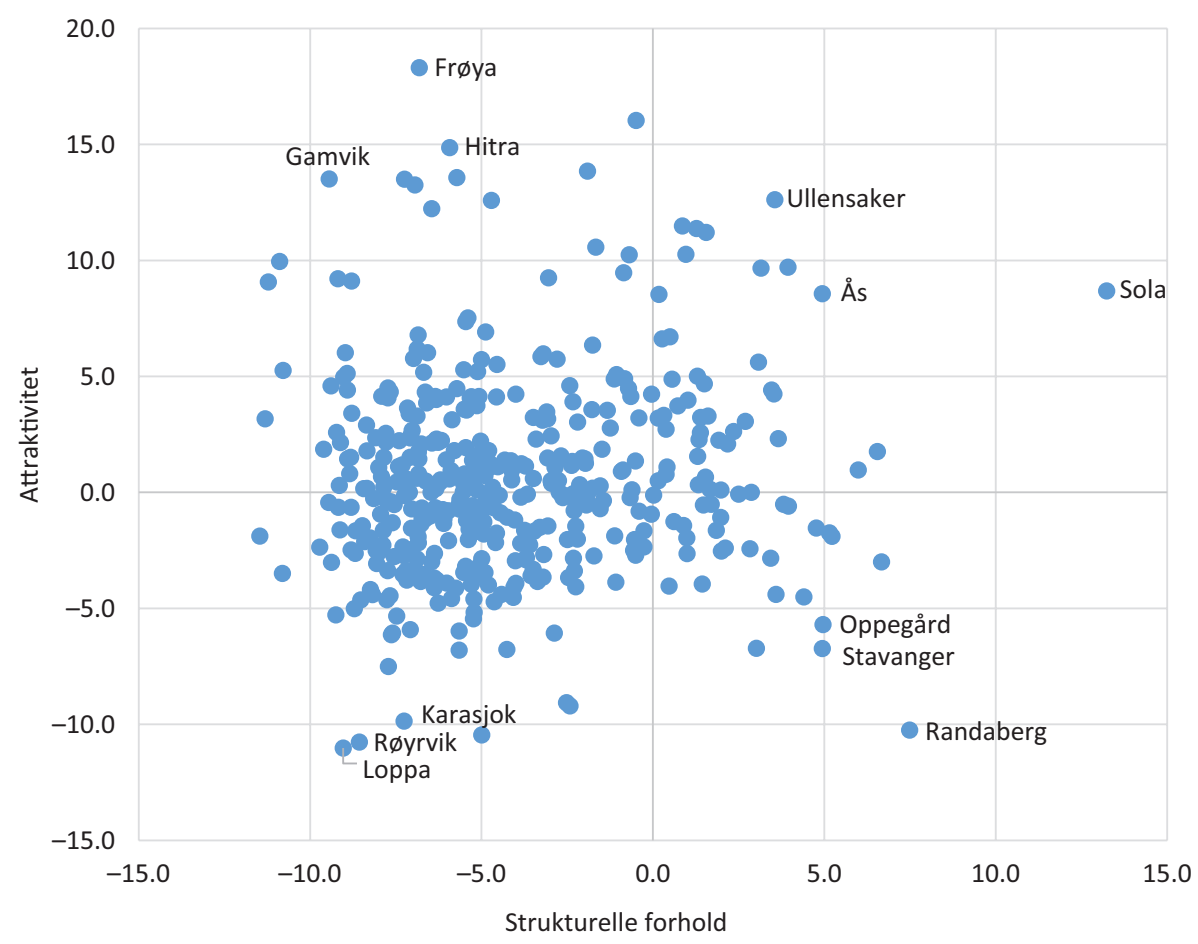

Figur 4.17 Vekstimpulser til befolkningen, knyttet til strukturelle forhold og til attraktivitet i perioden 2006-2015.

Nede til venstre har vi kommunene med den uheldige kombinasjonen av uheldig struktur og lav attraktivitet. Utgangspunktet for vekst var svakt i utgangspunktet, men resultatene ble enda svakere. Loppa, Røyrvik og Karasjok er slike kommuner.

Den siste kategorien, oppe til venstre, er kanskje den mest interessante. Det er kommuner som hadde dårlige betingelser for vekst i utgangspunktet, men som har overprestert. Kjerringer mot strømmen. Frøya, Hitra og Gamvik har hatt svært overraskende vekst de siste årene, tross ganske svake vekstbetingelser.

I figur 4.18 har vi vist utviklingen i folketallet i de kommunene som er kjennetegnet av svake strukturelle vekstbetingelser, men med enten svært sterk eller svært svak samlet attraktivitet. Det er de kommunene som vi navnga på venstre side i figur 4.17. 


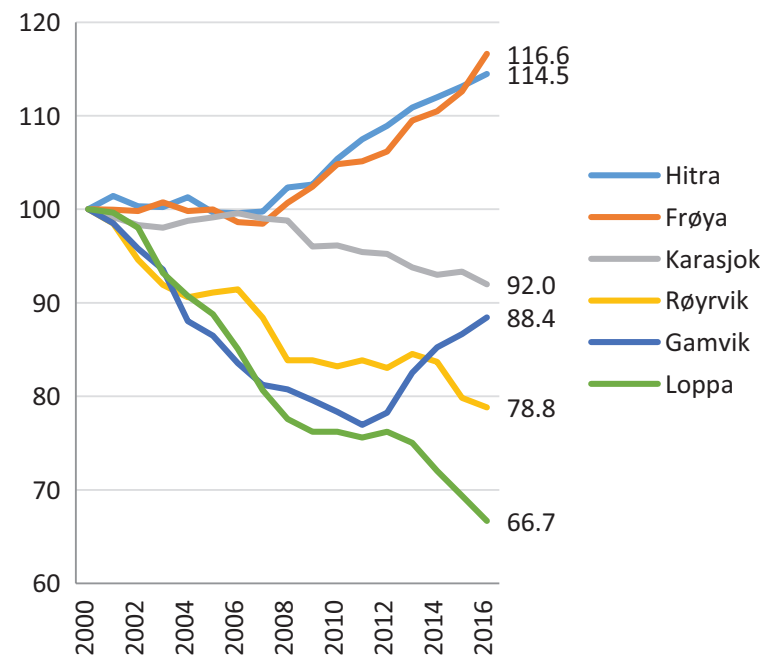

Figur 4.18 Befolkningsutvikling, indeksert slik at nivået i $2000=100$.

Hitra, Frøya og Karasjok hadde nesten identisk utvikling i folketallet fra 2000 til 2007. Etter 2006 har Hitra og Frøya vært blant de mest attraktive kommunene i landet. Det har ført til at kommunene har gått fra stagnasjon i folketallet til sterk vekst. Kontrasten til utviklingen i Karasjok er stor. Karasjok har mistet omtrent 8 prosent av folketallet siden 2007 .

Gamvik og Loppa hadde også omtrent samme befolkningsutvikling inntil 2011. Etter det har Gamvik vært oppsiktsvekkende attraktiv og hatt sterk vekst i folketallet, mens Loppa har hatt en svært sterk nedgang.

Eksemplene Frøya, Hitra og Gamvik viser at selv små distriktskommuner med svake strukturelle forutsetninger for vekst kan oppnå høy attraktivitet og dermed oppnå befolkningsvekst mot alle odds.

I figur 4.19 er kommuner med svært gode strukturelle betingelser, men med ulik attraktivitet. Ullensaker, Ås og Sola er kommuner med kombinasjonen av gunstige strukturelle vekstbetingelser og høy attraktivitet. Det har gitt svært sterk vekst i folketallet. Ullensaker har hatt en befolkningsvekst på 70 prosent i perioden, mens Ås og Sola har hatt henholdsvis 40 og 38 .

Stavanger, Randaberg og Oppegård har hatt svært gunstige betingelser for vekst, men veksten har blitt langt svakere enn forventet. Veksten i folketallet har likevel vært sterk, mellom 17 og 22 prosent. For slike kommuner er det ikke en utfordring å skape vekst. Befolkningsveksten er nærmest uunngåelig. 


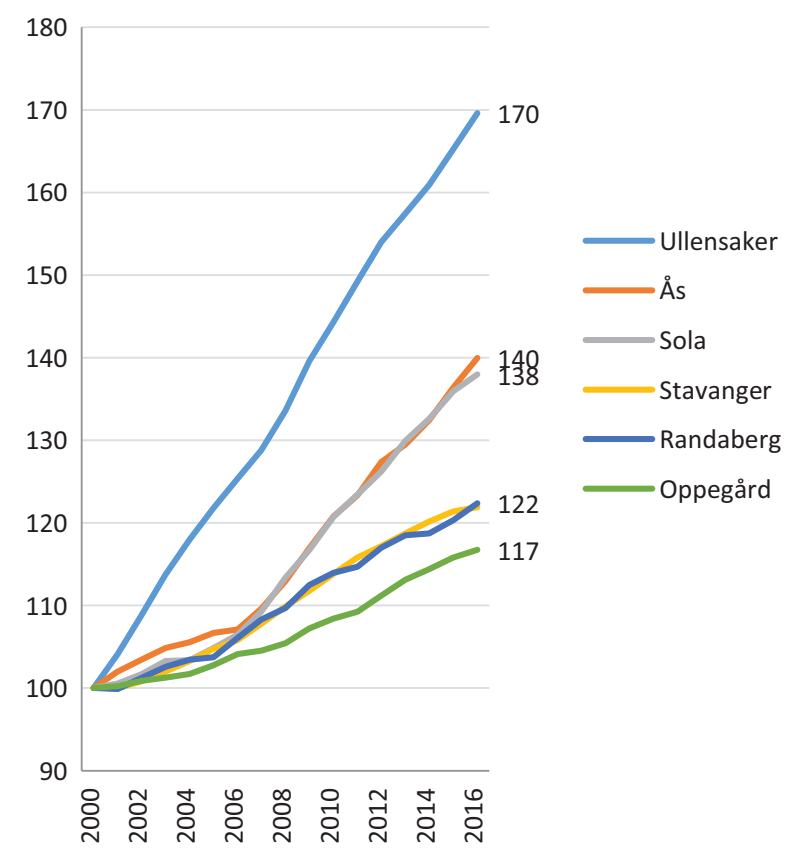

Figur 4.19 Befolkningsutvikling, indeksert slik at nivået i $2000=100$.

\subsection{Attraktivitet i Sverige og Danmark}

Attraktivitetsmodellen vi har utviklet for Norge, kan også brukes til å analysere svenske og danske kommuner. Finner vi de samme sammenhengene? I tabellen under viser vi de parametrene som vi fikk for bostedsmodellen ved å legge inn data fra kommuner i Sverige og Danmark.

\subsubsection{Bostedsattraktivitet}

Vi har sammenliknet betaverdiene fra kommuneanalysene i Danmark og Sverige med de tilsvarende betaverdiene fra norske kommuner og regioner. Norske kommuner er gjennomgående mindre enn danske og svenske. Norge har 428 kommuner per dags dato, mens Sverige har 290 og Danmark 99.

Dermed vil det kanskje være mer relevant å sammenlikne resultatene fra danske og svenske kommuner med norske regioner.

Svenske kommuner har lavere betaverdier for arbeidsplassvekst enn danske kommuner og norske regioner. Betaverdiene til Sverige betyr at en relativ 
Tabell 4.1 Betaverdier fra regresjonsanalysene.

\begin{tabular}{lcccc}
\hline & $\begin{array}{c}\text { Norge } \\
\text { kommuner }\end{array}$ & $\begin{array}{c}\text { Norge } \\
\text { regioner }\end{array}$ & $\begin{array}{c}\text { Sverige } \\
\text { kommuner }\end{array}$ & $\begin{array}{c}\text { Danmark } \\
\text { kommuner }\end{array}$ \\
\hline Arbeidsplassvekst år 0 & 0,15 & 0,17 & 0,10 & 0,23 \\
Arbeidsplassvekst år -1 & 0,09 & 0,12 & 0,05 & 0,00 \\
Arbeidsplassvekst år -2 & 0,07 & 0,10 & 0,05 & 0,10 \\
Nabovekst & 0,18 & 0,21 & 0,28 & 0,17 \\
Størrelse & 0,13 & 0,07 & 0,18 & 0,20 \\
Arbeidsmarkedsintegrasjon & 0,65 & 0,94 & 0,40 & 0,47 \\
Intern arb.m.integrasjon & & 0,49 & & \\
\hline
\end{tabular}

arbeidsplassvekst på 10 prosent gir en ekstra netto innflytting på 1,0 prosent (av folketallet) $i$ år en, 0,5 prosent $i$ år to og 0,5 prosent $i$ år tre. En konstant relativ arbeidsplassvekst på 10 prosent vil da gi ekstra innflytting tilsvarende 2 prosent per år. Norske kommuner med samme relative arbeidsplassvekst vil få en ekstra innflytting på 3,1 prosent, mens danske vil få en ekstra innflytting på 3,3 prosent. Dermed kan det se ut til at det er noe lavere sammenheng mellom relativ arbeidsplassvekst og flytting i svenske kommuner enn i danske kommuner og norske regioner.

Flyttingen til svenske kommuner blir imidlertid i sterkere grad påvirket av størrelse og nabovekst enn hva som er tilfellet med norske kommuner. Norske kommuner blir sterkest påvirket av arbeidsmarkedsintegrasjonen. For norske regioner har vi også den interne arbeidsmarkedsintegrasjonen med i modellen. Det gjør at vi har en ekstra forklaringsvariabel.

I den danske analysen har vi data for årene 2011-2014. I den norske analysen har vi data fra 2000 til 2015, mens vi i den svenske har fra 2000 til 2014. Når vi finner en betaverdi på o,o for arbeidsplassvekst i år -1 i den danske analysen, antar vi at det er et tilfeldig utslag. Hvis vi hadde hatt datasett for flere år, vil nok denne verdien bli positiv.

I figur 4.20 ser vi hvordan faktisk og forventet flytting har variert i norske, svenske og danske kommuner i perioden 2011-2014.

De norske kommunene har større spredning, ettersom det er langt flere av dem og mange er svært små. De danske kommunene har minst spredning, ettersom de er færre i antall enn kommunene i Norge og Sverige. 


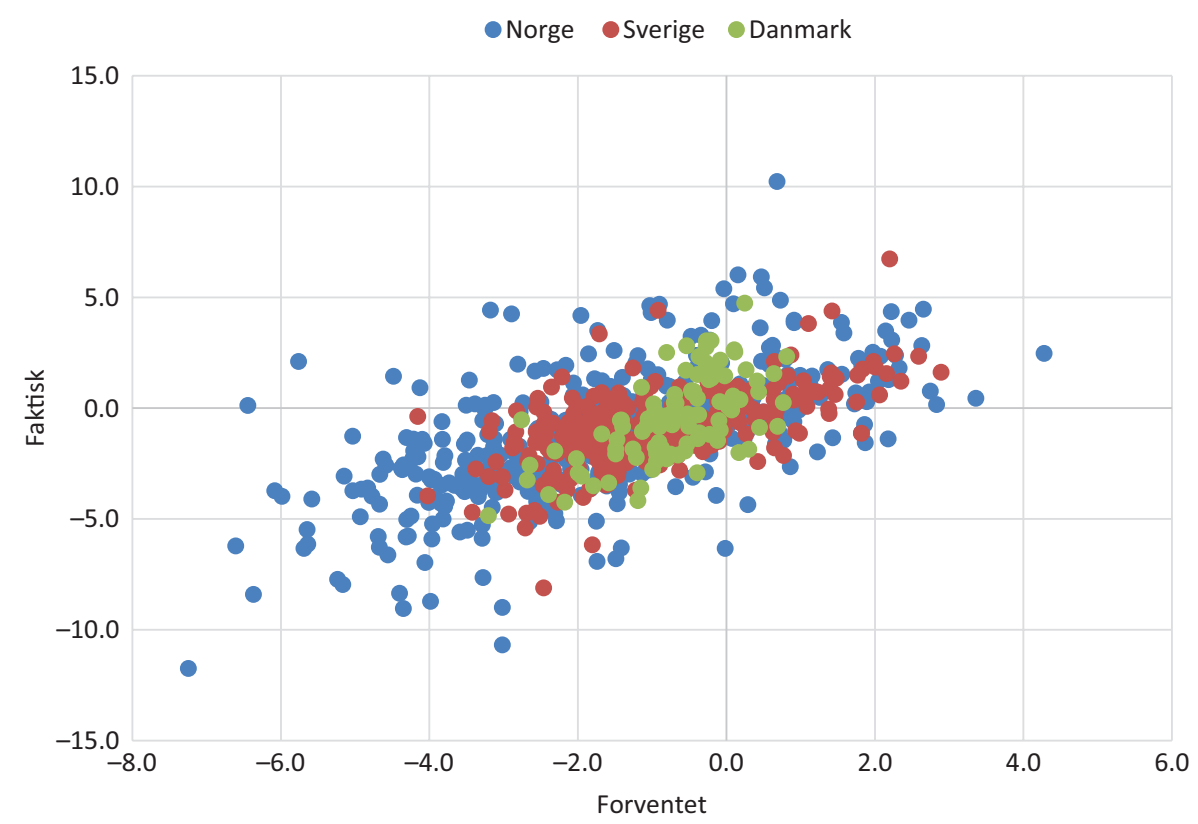

Figur 4.20 Faktisk og forventet relativ flytting i norske, svenske og danske kommuner i perioden 2011-2014.

Modellen forklarer omtrent like mye av variasjonen mellom nettoflyttingen i de tre landene. Verdiene for $\mathrm{R}^{2}$ ligger mellom $0,35 \mathrm{og} 0,40$. Forklaringskraften til modellen er, som vi har vist tidligere, større dess lengre periode vi bruker. Her er det en periode på fire år.

\subsubsection{Næringsattraktivitet}

Forventningsverdien til arbeidsplassveksten i næringslivet er summen av nasjonal vekst, bransjeeffekten og befolkningseffekten. Vi kan se på forventet vekst og faktisk vekst i næringslivet i de tre landene i figur 4.21. Vi bruker da tidsperioden 2011-2014, da vi har data for alle landene.

Modellen gir minst forklaringskraft for de norske kommunene $\left(\mathrm{R}^{2}=0,11\right)$. I Norge er det mange små kommuner med ganske lite næringsliv, og da blir det lett store tilfeldige variasjoner. Hvis vi bruker regionnivå, får vi betydelig bedre treffsikkerhet i modellen.

De svenske kommunene har i gjennomsnitt betydelig bedre vekst enn de andre. Den nasjonale veksten i antall arbeidsplasser i næringslivet har vært 


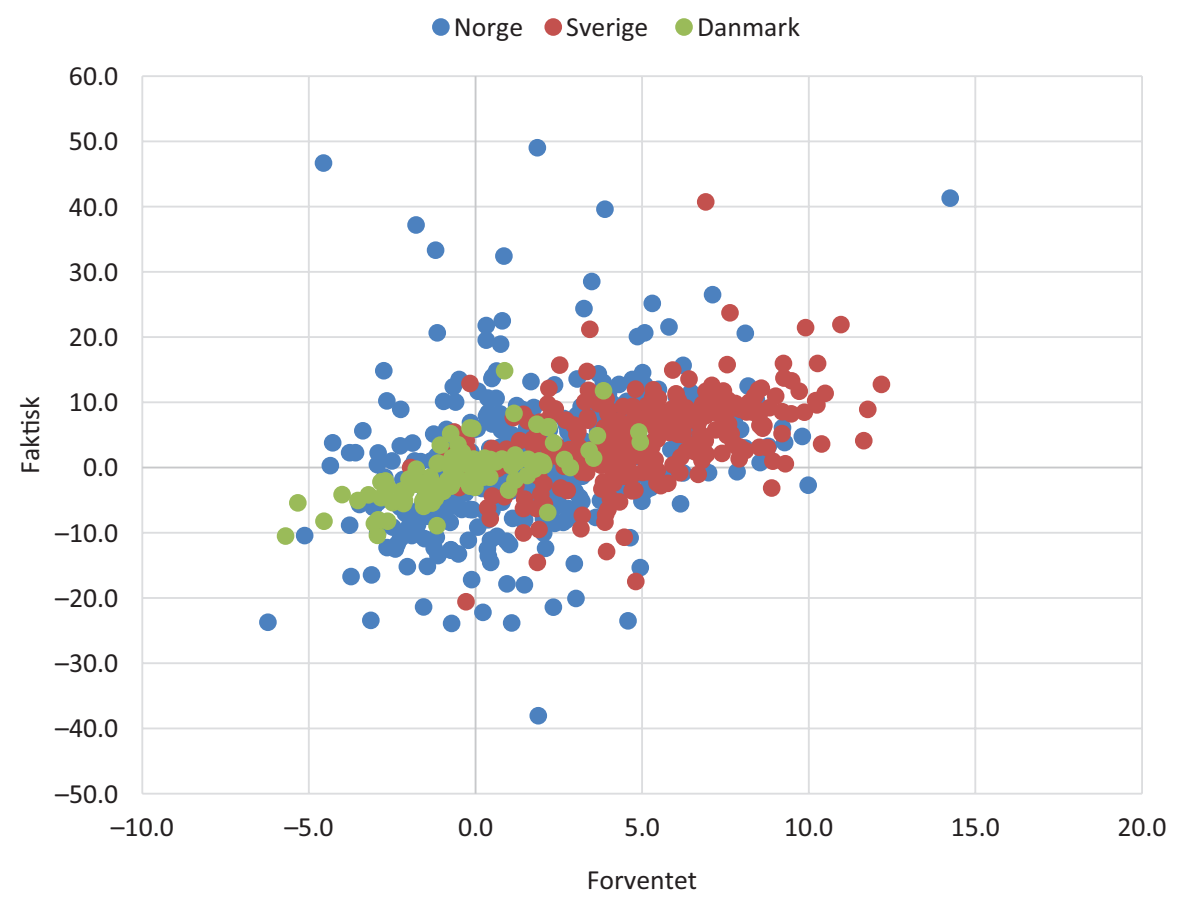

Figur 4.21 Forventet og faktisk vekst i antall arbeidsplasser i næringslivet, prosent, i perioden 2011-2014.

høyest i Sverige. Modellen har bedre forklaringskraft i Sverige enn i Norge $\left(\mathrm{R}^{2}=0,21\right)$. Det skyldes sannsynligvis at de svenske kommunene er større.

De danske kommunene har i gjennomsnitt langt lavere vekst enn kommunene i Norge og Sverige. Modellen har større forklaringskraft for danske kommuner $\left(R^{2}=0,46\right)$. De danske kommunene er større enn de svenske og de norske.

\subsubsection{Regionale mønstre i Sverige}

Vi skal se på flyttemønstrene i kommunene i Sverige. I kartene i figur $4.22 \mathrm{er}$ nettoflyttingen til svenske kommuner vist til venstre. I det midterste kartet ser vi hvilken effekt arbeidsplassveksten har i egen kommune. I kartet til høyre ser vi hvordan nettoflyttingen avviker fra forventet verdi ut fra arbeidsplassveksten. Dette avviket kaller vi brutto bostedsattraktivitet.

I det venstre kartet ser vi at Sverige har et sentralisert flyttemønster der Stockholmsregionen har høy innflytting. Det er også høy innflytting til 


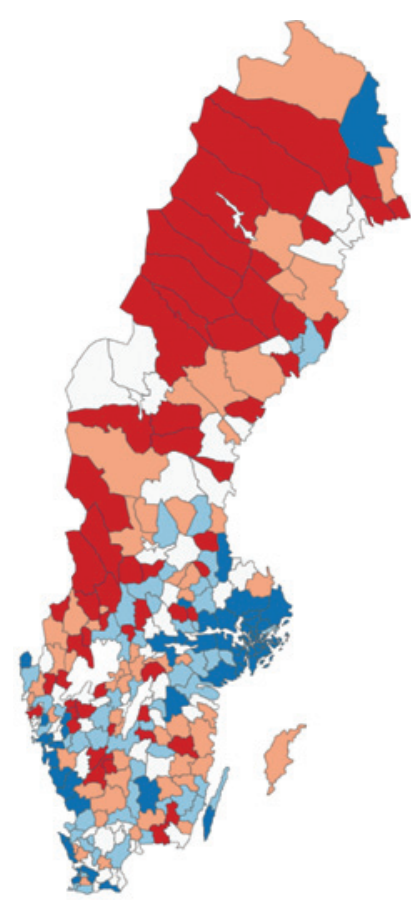

Nettoflytting 2009-2014

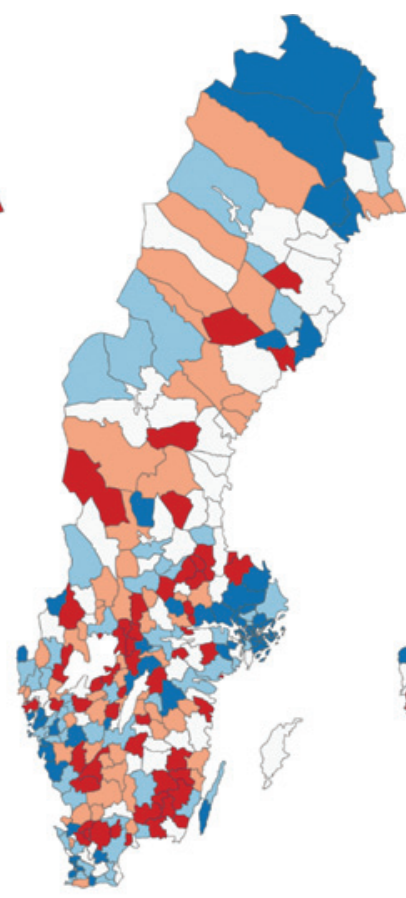

Effekt av arbeid 2009-2014

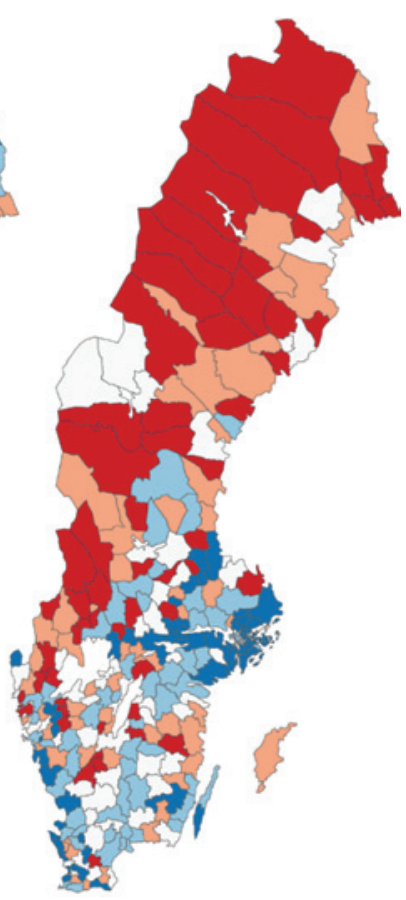

Brutto bostedsattraktivitet 2009-2014

Figur 4.22 Nettoflytting, arbeidsplasseffekt og brutto bostedsattraktivitet i svenske kommuner. Kommunene er delt inn i fem kvantiler, der mørkeblå er de høyeste verdiene og røde er de laveste. Hvite kommuner ligger i den midterste kvantilen.

vestkysten, spesielt rundt Göteborg og Malmö. Kommunene i nord og langs norskegrensen har størst utflytting.

I det midterste kartet ser vi effekten av arbeidsplassveksten. Mange av kommunene i nord har hatt ganske sterk arbeidsplassvekst i denne perioden.

I det høyre kartet ser vi brutto bostedsattraktivitet. Det er et mål for tiltrekning av innbyggere utover det som kan forventes av arbeidsplassveksten alene. Kommunene i nord og langs norskegrensen har mye lavere flyttetall enn arbeidsplassveksten skulle tilsi. Stockholmsregionen og vestkysten trekker til seg langt mer innflytting enn forventet ut fra arbeidsplassveksten i disse områdene.

Vi skal bruke de samme strukturelle flyttefaktorene som vi avdekket for norske kommuner, for å forklare den delen av flyttemønstrene i svenske kommuner som ikke blir forklart av arbeidsplassveksten. 


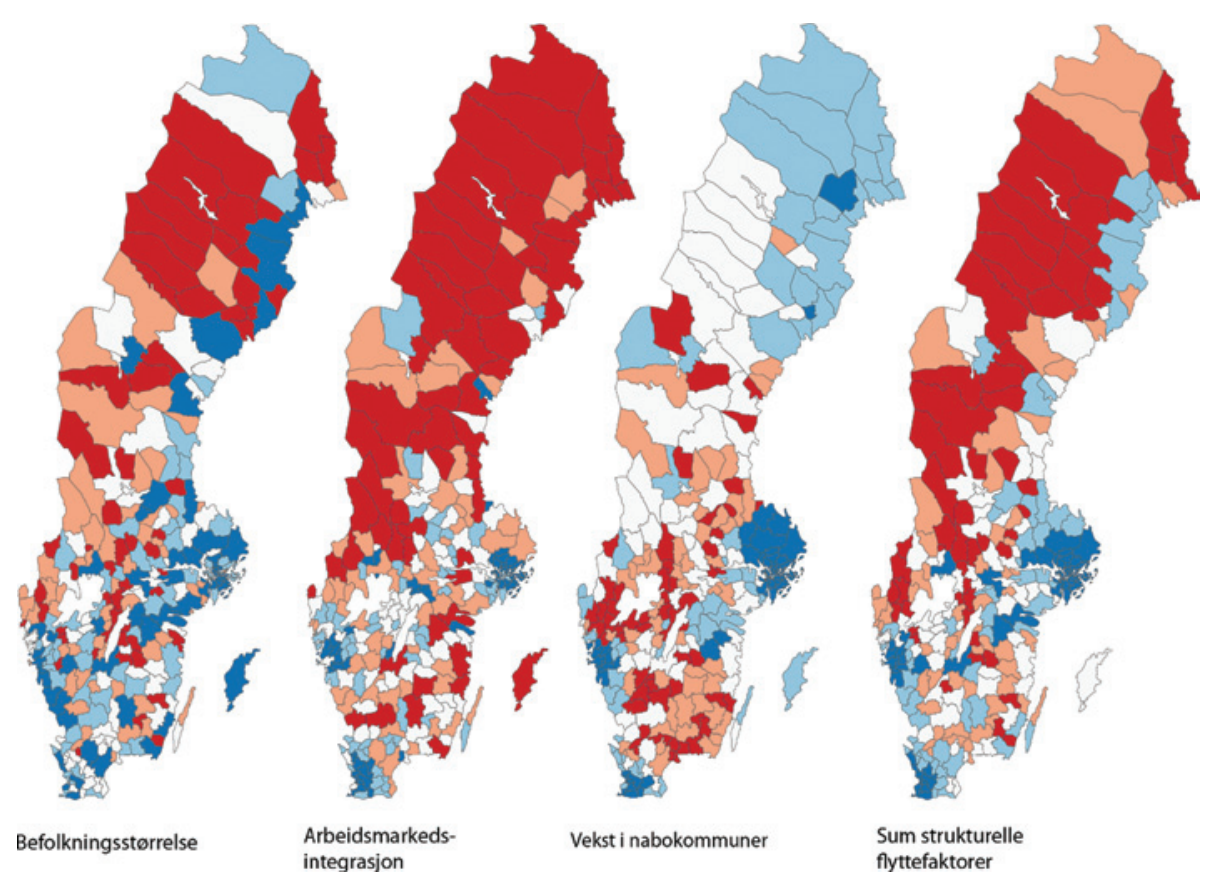

Figur 4.23 Beregnet effekt av kommunenes størrelse (innbyggertall), arbeidsmarkedsintegrasjon og arbeidsplassvekst i nabokommuner i svenske kommuner i perioden 2009-2014. I kartet til høyre er effekten av alle de tre strukturelle flyttefaktorene summert.

Vi så i tabell 4.1 at nettoflyttingen til svenske kommuner så ut til å bli sterkere påvirket av kommunens størrelse enn i Norge. I kartet til venstre ser vi hvordan kommunenes størrelse, målt i innbyggertall, påvirker nettoflyttingen. Kommuner med mange innbyggere trekker til seg innflytting i større grad enn små kommuner, selv om arbeidsplassveksten er den samme.

Kommunene i Sverige er også svært ulike med hensyn til arbeidsmarkedsintegrasjonen. I områdene rundt de tre største byene Stockholm, Göteborg og Malmö er det mange kommuner med høy arbeidsmarkedsintegrasjon. Tilsvarende er det mange kommuner i nord med svak arbeidsmarkedsintegrasjon. Kommunene i nord er geografisk store og tynt befolket. Kombinasjonen av størrelse og arbeidsmarkedsintegrasjon er et mål på hvor mange arbeidsplasser det er i pendlingsavstand. I store kommuner, eller i kommuner som har høy arbeidsmarkedsintegrasjon, vil en innbygger kunne nå et stort antall potensielle arbeidsplasser. Det kan være en forklaring på hvorfor flere flytter til slike områder. I små kommuner med lav arbeidsmarkedsintegrasjon blir valgmulighetene for arbeid langt mindre. 
Naboveksten er en faktor som vil variere over tid. I den perioden vi studerer her, har kommunene i nord fått en positiv vekstimpuls gjennom naboveksten. De tre storbyområdene har imidlertid de sterkeste vekstimpulsene.

I det siste kartet har vi summert effekten av de strukturelle flyttefaktorene. Her ser vi et ganske tydelig mønster, hvor de tre største byregionene har de mest gunstige strukturelle betingelsene for å fa innflytting, mens kommunene i nord og langs norskegrensen har de minst gunstige betingelsene.

Vi skal oppsummere analysen av flyttemønstrene i kommunene i Sverige. Vi ser nettoflyttingen til svenske kommuner i kartet til venstre i figur 4.24. Effekten av arbeidsplassveksten i egen kommune i kart nummer to fra venstre, dernest summen av de strukturelle flyttefaktorene og til slutt kommunenes bostedsattraktivitet.

I kartene i figur 4.24 ser vi at kartet over nettoflytting og de strukturelle flyttefaktorene er ganske like. De strukturelle flyttefaktorene ser dermed ut til å forklare mye av flyttemønsteret i svenske kommuner. Arbeidsplassveksten har ikke vært en sterkt sentraliserende kraft i denne perioden. Riktignok har

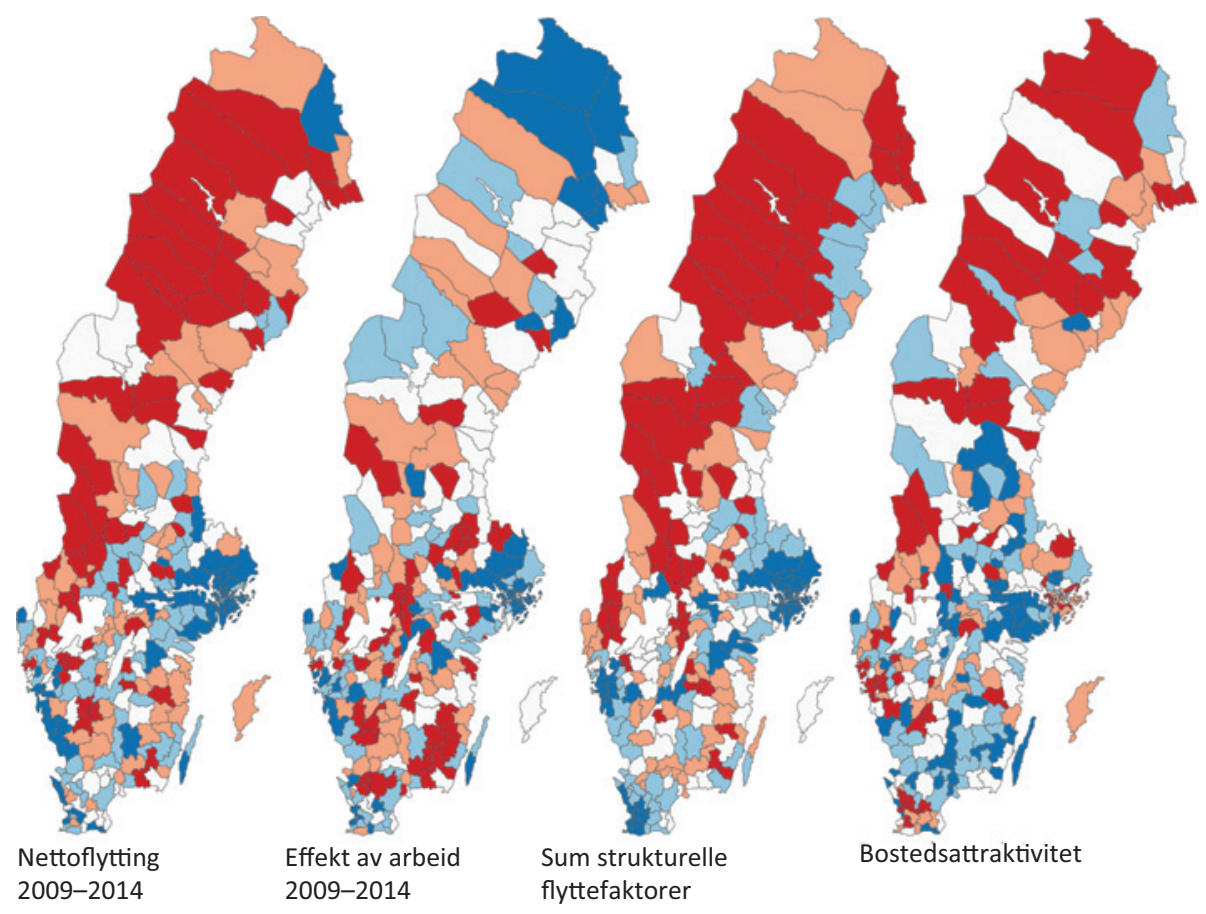

Figur 4.24 Variasjon i nettoflytting, effekten av arbeidsplassvekst i egen kommune, sum strukturelle flyttefaktorer og bostedsattraktivitet i svenske kommuner i perioden 2009-2014. 
arbeidsplassveksten vært sterkest i og rundt de tre største byene, men mange kommuner i nord har også hatt sterk arbeidsplassvekst i perioden.

I det siste kartet ser vi variasjonen i kommunenes bostedsattraktivitet. Bostedsattraktiviteten er et mål for om nettoflyttingen har avveket fra forventet verdi, som avhenger av arbeidsplassveksten og de strukturelle flyttefaktorene i den enkelte kommune. Kommuner som har et høyt positivt avvik, har høyere nettoflytting enn forventet ut fra sin arbeidsplassvekst og strukturelle betingelser. Slike kommuner trekker til seg innbyggere uten at det kan forklares av arbeidsplassvekst eller struktur (som avhenger av lokalisering). Vi kan se at det er flere kommuner i nord som faktisk har vært attraktive for bosetting i denne perioden.

\subsubsection{De mest og minst attraktive bostedskommunene i Sverige}

Sundbyberg har hatt høyest uforklart nettoflytting av alle svenske kommuner i perioden 2009-2014. Fagersta og Strömstad er nummer to og tre. I disse tre kommunene har det vært netto innflytting på mellom 5,6 og 7,1 prosent av

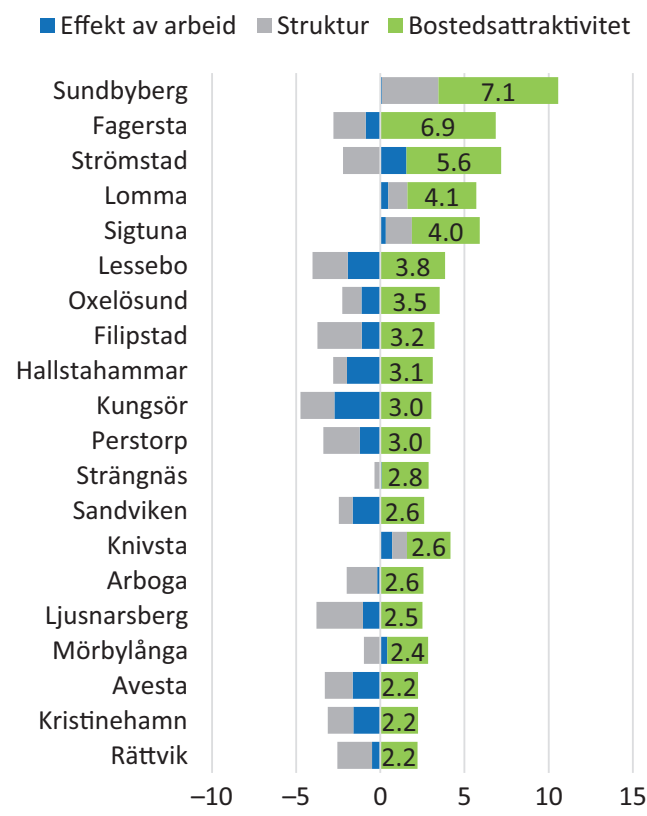

Figur 4.25 Kommunene med høyest bostedsattraktivitet i perioden 2009-2014. 


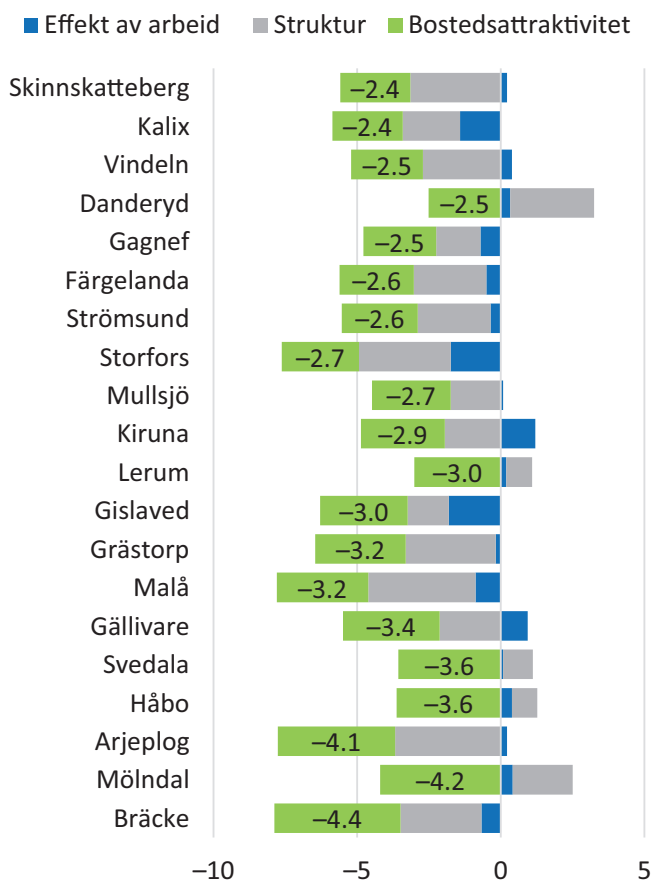

Figur 4.26 Kommunene med lavest bostedsattraktivitet i perioden 2009-2014.

folketallet over det som er forventet ut fra arbeidsplassvekst og strukturelle betingelser.

Av de mest attraktive svenske bostedskommunene har Sundbyberg og Knivsta også høyere arbeidsplassvekst enn gjennomsnittet og gunstige strukturelle betingelser. I kommuner som Lessebo og Kungsör har arbeidsplassutviklingen vært svak samtidig som at de strukturelle flyttefaktorene har bidratt negativt. I disse kommunene har det derfor ikke vært spesielt høy innflytting.

Det er ingen kommuner i det nordlige Sverige med blant de 20 mest attraktive bostedskommunene. Rättvik i Dalarna er den nordligste kommunen som er med på denne lista.

De nordligste fylkene - Norrbotten, Västerbotten og Jämtland - er representert med 8 kommuner blant de 20 minst attraktive bostedskommunene. Bräcke, Mölndal og Arjeplog har vært aller minst attraktive for bosetting i perioden 2009-2014.

Blant de minst attraktive finner vi flere kommuner som har hatt både sterk arbeidsplassvekst og gunstige betingelser. Danderyd, Lerum, Svedala, Håbo og 
Mölndal er slike kommuner. I disse kommunene ville vi forventet at nettoinnflyttingen var sterkere enn landsgjennomsnittet, men disse kommunene har ikke realisert sine forutsetninger for befolkningsvekst. I Norge finner vi gjerne at slike kommuner har hatt for lite boligbygging, men vi har ikke undersøkt dette i Sverige.

I kommuner som Storfors, Malå og Bräcke faller den lave bostedsattraktiviteten sammen med både svak arbeidsplassutvikling og svake strukturelle betingelser. I slike kommuner blir det sterk netto utflytting.

\subsubsection{Næringsutvikling i Sverige}

I kartene i figur 4.27 under ser vi effekten av de strukturelle forholdene som har betydning for arbeidsplassveksten i næringslivet. Det er bransjeeffekten og befolkningseffekten.

Kartet over bransjeeffekten viser at mange kommuner i det nordlige Sverige har hatt en gunstig bransjestruktur i perioden. Det betyr at næringslivet i disse kommunene har hatt en konsentrasjon til bransjer som har hatt vekst i Sverige i denne perioden. Kommunene med minst gunstig bransjestruktur ligger for det meste i den sørlige delen. Stockholmregionen har imidlertid også en gunstig bransjestruktur.

Befolkningseffekten slår negativt ut for de fleste kommunene i den nordlige delen. Befolkningseffekten er mest positiv i og rundt de tre største byene. Den samlede struktureffekten er vist i kartet til høyre. Den samlede struktureffekten er også et mål for forventet arbeidsplassvekst i kommunene.

Nå kan vi sammenlikne den faktiske arbeidsplassveksten i næringslivet med den forventede veksten. Den forventede veksten bestemmes av de to strukturelle forholdene vi omtalte på forrige side: bransjestrukturen og befolkningsveksten.

Vi kan se at de regionale mønstrene for den faktiske arbeidsplassveksten i næringslivet (venstre kart) likner mønstrene for de strukturelle forholdene (midterste kart). Det ser vi ved at kartene likner hverandre.

Det siste kartet viser avviket mellom faktisk og forventet arbeidsplassvekst. Detbruker vi som indikator for næringsattraktivitet. Kommuner der arbeidsplassveksten i næringslivet har vært høyere enn forventet, framstår som attraktive for næringsliv i perioden.

Det er ingen spesielle og tydelige mønstre i næringsattraktiviteten. Det skal det i prinsippet heller ikke være, fordi de strukturelle faktorene er «renset bort». 


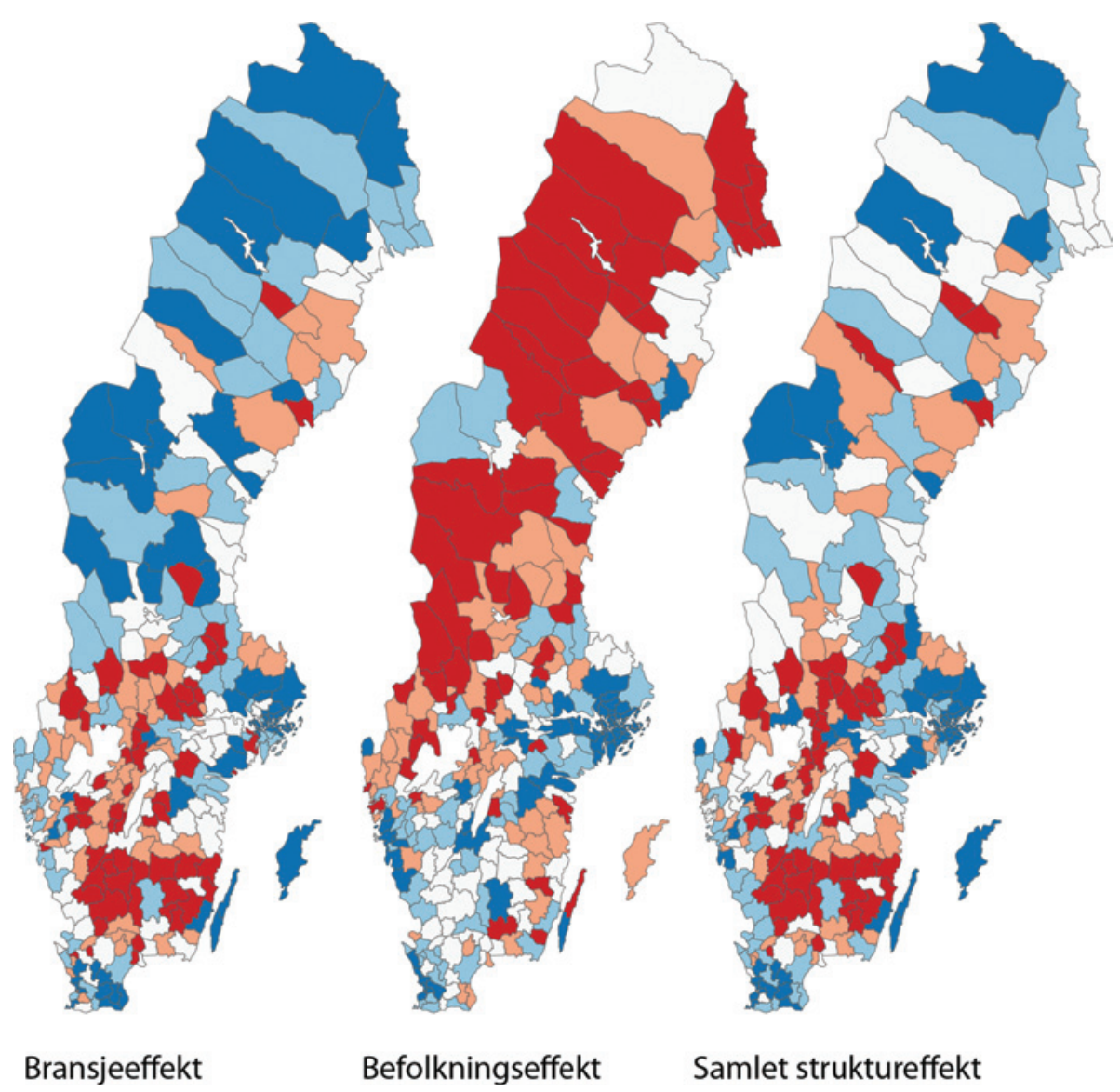

Figur 4.27 Bransjeeffekten, befolkningseffekten og samlet struktureffekt på arbeidsplassutviklingen i næringslivet i svenske kommuner i perioden 2009-2014.

På neste side skal vi se hvilke kommuner som har vært spesielt attraktive eller lite attraktive.

\subsubsection{Kommunene som er mest attraktive for næringslivet}

Pajala, Mölndal og Eda er de mest attraktive kommunene for næringsliv i perioden 2009-2014. I Pajala har næringslivet hatt en vekst over forventet verdi tilsvarende 20,1 prosent av samlet sysselsetting. Pajalas vekst er i stor grad knyttet til vekst i gruvedrift. Denne veksten ser også ut til å ha smittet over til bransjer som bygg og anlegg, agentur, transport og overnatting. 


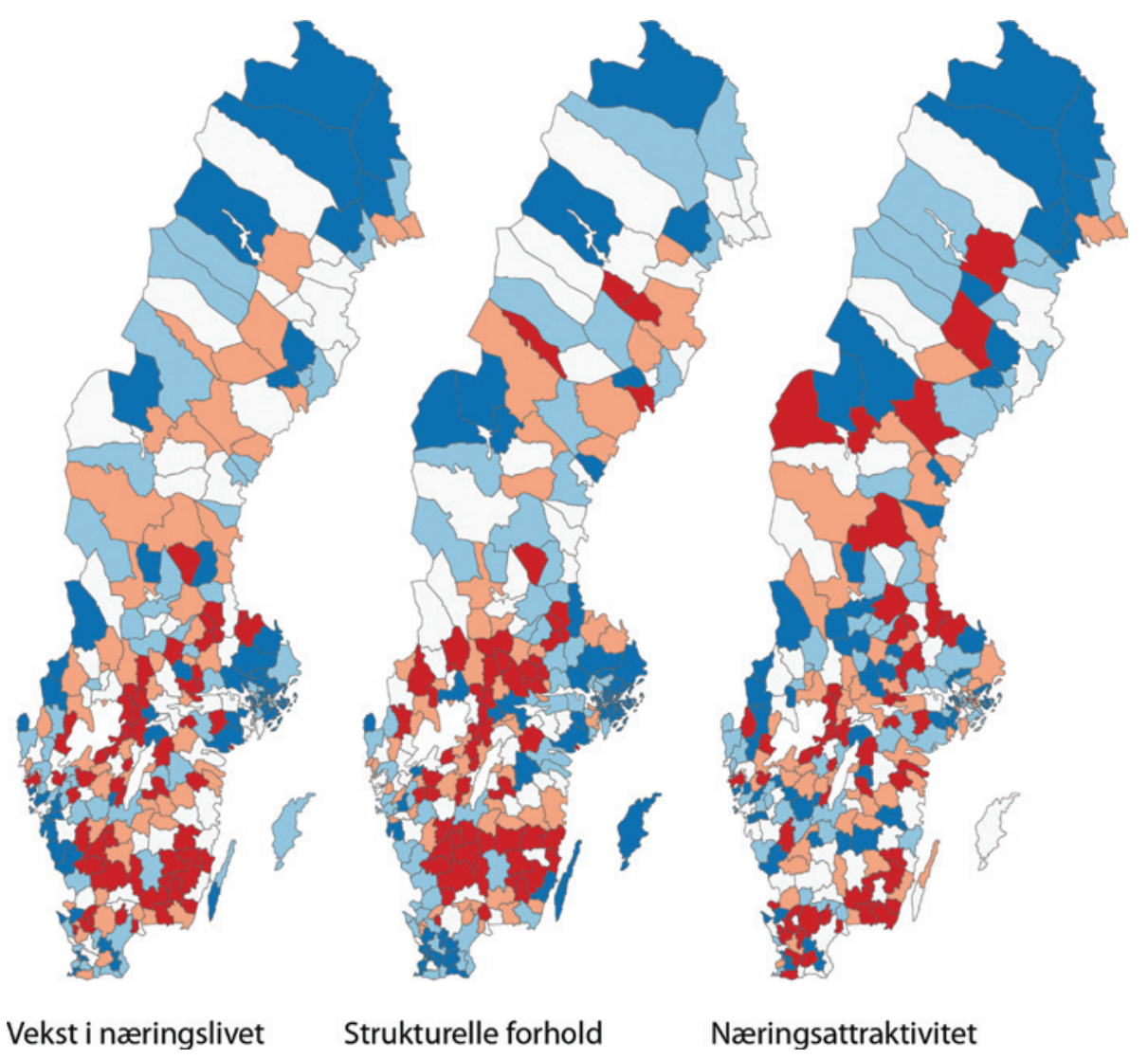

Figur 4.28 Variasjoner i arbeidsplassvekst i næringslivet, strukturelle forhold for vekst og næringsattraktivitet i svenske kommuner i perioden 2009-2014.

Mölndal er nabokommune til Göteborg. Veksten i Mölndal er spesielt knyttet til de regionale næringene. Eda kommune grenser til Norge. I Eda er det besøksnæringene som har skapt den sterke veksten i næringslivet. Grensehandelen har dermed spilt en vesentlig rolle for næringsattraktiviteten i Eda.

\subsubsection{De minst attraktive næringskommunene}

Kungsör, Trollhättan og Laxå har vært minst attraktive for næringsliv i perioden 2009-2014. Alle disse tre kommunene er industrikommuner hvor det har vært sterk nedgang i antall industriarbeidsplasser. I Trollhättan kan omtrent hele nedgangen knyttes til nedleggelsen av Saab. 


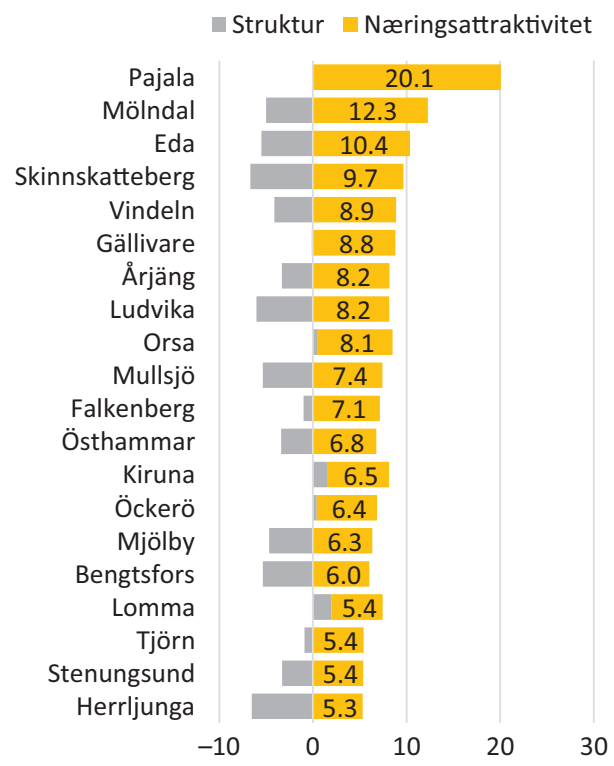

Figur 4.29 De mest attraktive næringskommunene i Sverige i perioden 2009-2014. Benevningen er prosent av samlet sysselsetting.

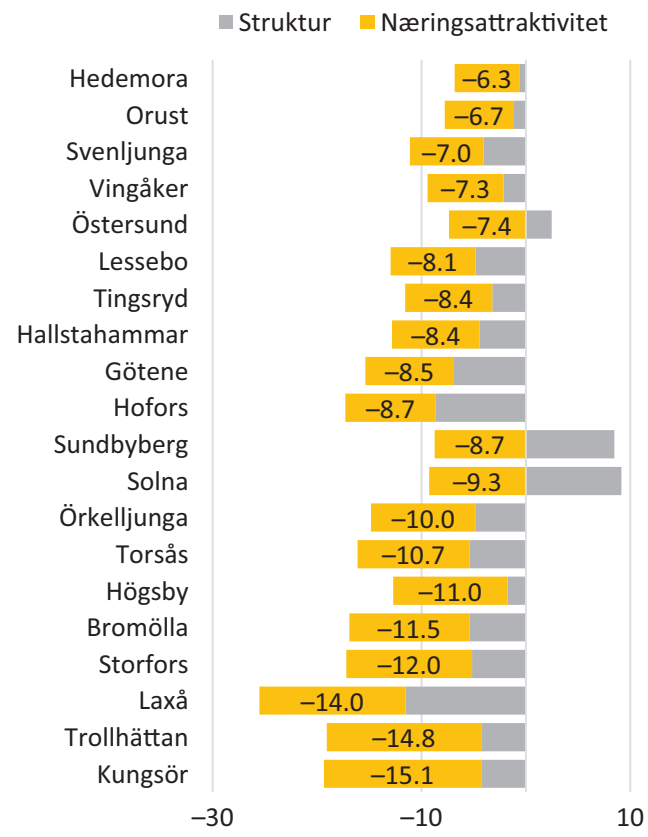

Figur 4.30 De minst attraktive næringskommunene i Sverige i perioden 2009-2014. Benevningen er prosent av samlet sysselsetting. 
På lista over de minst attraktive næringskommunene finner vi også kommuner som Sundbyberg og Solna. Dette er kommuner som har hatt svært gunstige forhold for vekst i næringslivet, men som ikke har realisert potensialet for vekst. Tidligere i rapporten har vi sett at Sundbyberg var den mest attraktive bostedskommunen i Sverige.

\subsubsection{Samlet attraktivitet}

Vi kan kombinere tallene for bosteds- og næringsattraktivitet for å få et mål for samlet attraktivitet. Vi bruker den samme metoden som vi brukte på norske kommuner.

Som i Norge, vil de fleste kommunene ha en samlet struktureffekt som er negativ. Det vil si at de ikke kan forvente samme nettoinnflytting som landsgjennomsnittet. Det er på grunn av at de største kommunene har en positiv struktureffekt, og da særlig Stockholm, Göteborg og Malmö.

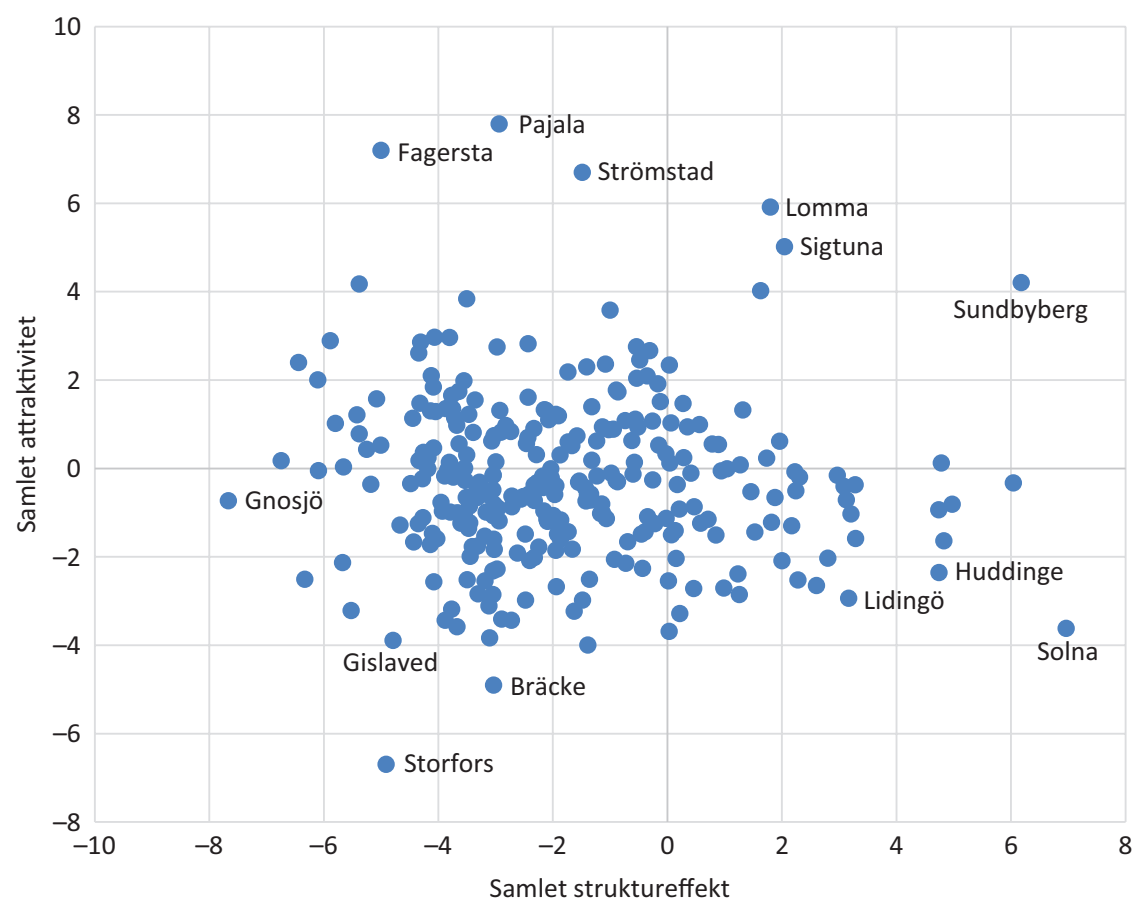

Figur 4.31 Samlet struktureffekt og samlet attraktivitet i svenske kommuner i perioden 2009-2014. 
De tre kommunene med høyest samlet attraktivitet er Pajala, Fagersta og Strömstad. Det er kommuner hvor de strukturelle betingelsene er lite gunstige. Disse kommunene har dermed fătt en sterk netto innflytting tross sine betingelser.

Lomma, Sigtuna og Sundbyberg er kommuner hvor de strukturelle betingelsene er svært gode, men hvor veksten har oversteget forventningene med god margin. Dette er kommunene med høyest netto innflytting, fordi den faktiske nettoflyttingen er summen av struktureffekten og attraktiviteten.

Solna, Huddinge og Lidingö er representanter for kommuner med svært gunstige strukturelle betingelser, men hvor den potensielle veksten ikke har blitt realisert.

Storfors, Bräcke og Gislaved har den uheldige kombinasjonen av svært svake strukturelle betingelser og svært lav attraktivitet.

\subsubsection{Sveriges mest og minst attraktive kommuner}

Når vi kombinerer attraktiviteten for bosted og næringsliv, er det Pajala, Fagersta og Strömstad som samlet sett har vært mest attraktive i perioden 2009-2014.

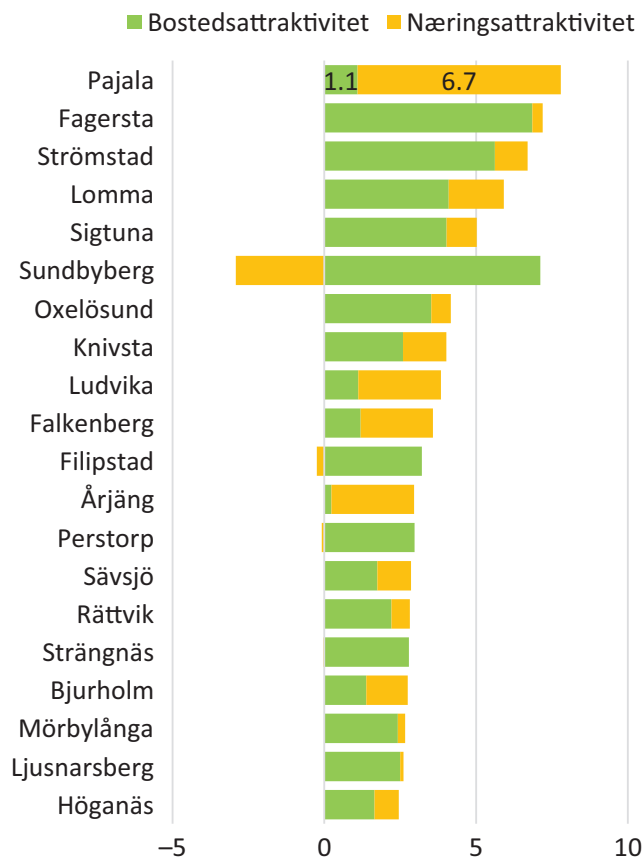

Figur 4.32 De mest attraktive kommunene i Sverige i perioden 2009-2014. 


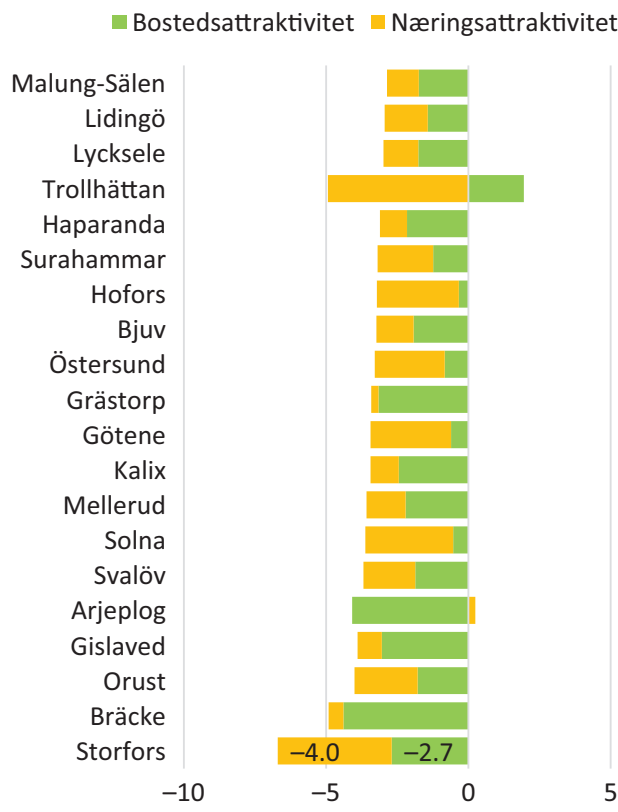

Figur 4.33 De minst attraktive kommunene i Sverige i perioden 2009-2014.

Kommuner som Pajala, Ludvika, Falkenberg og Årjäng har sin attraktivitet knyttet til næringslivet. Kommuner som Sundbyberg og Filipstad er bare attraktive som bosted.

Tallene for attraktivitet kan tolkes som hvor mye ekstra innflytting (i prosent av folketallet) som kommunen har fătt i perioden. I Pajala har det vært en ekstra innflytting på til sammen 7,8 prosent. Av dette kan 6,7 prosent tilskrives den sterke veksten i antall arbeidsplasser. Pajala har imidlertid også fått 1,1 prosent mer innflytting enn arbeidsplassveksten skulle tilsi.

De minst attraktive kommunene i perioden er Storfors, Bräcke og Orust. I Storfors har forventet nettoflytting vært 6,7 prosent lavere enn forventet. 4,0 prosent kan tilskrives svak arbeidsplassutvikling i næringslivet, mens 2,7 prosent tilskrives svak bostedsattraktivitet.

\subsubsection{Regionale mønstre i Danmark}

Vi skal analysere flyttemønstrene i danske kommuner på samme måte som vi gjorde for Sverige. I kartene i figur 4.34 er nettoflyttingen til danske kommuner vist til venstre. I det midterste kartet ser vi effekten av arbeidsplassveksten 


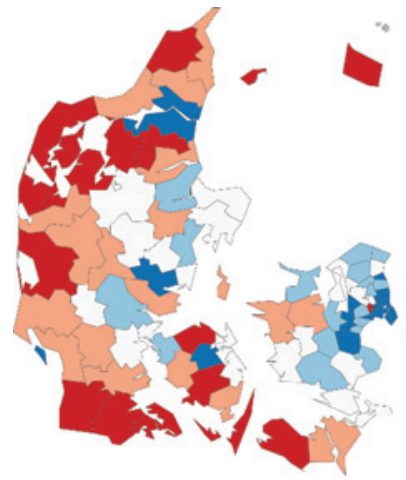

Nettoflytting 2011-2014

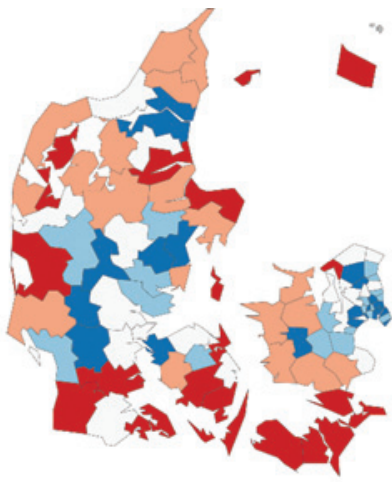

Effekt av arbeidsplassendringer 2011-2014

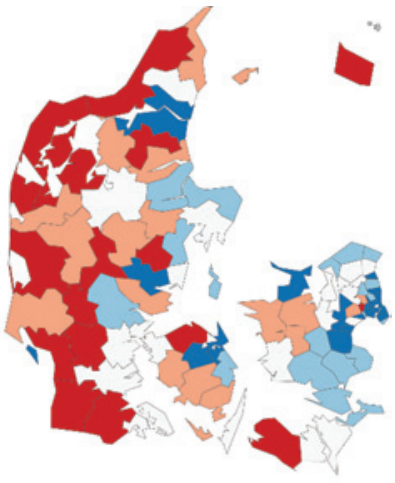

Brutto bostedsattraktivitet 2011-2014

Figur 4.34 Nettoflytting, arbeidsplasseffekt og brutto bostedsattraktivitet i danske kommuner. Kommunene er delt inn i fem kvantiler, der mørkeblå er de høyeste verdiene og de røde er de laveste. Hvite kommuner ligger i den midterste kvantilen. Bornholm er flyttet for å komprimere kartene.

i egen kommune. I kartet til høyre ser vi hvordan nettoflyttingen avviker fra forventet verdi ut fra arbeidsplassveksten. Dette avviket kaller vi brutto bostedsattraktivitet.

I det venstre kartet ser vi at Danmark har et flyttemønster der kommunene i nærheten av København, Odense, Horsens og Aalborg har høyest netto innflytting. I periferien finner vi de fleste kommunene med lave verdier for nettoflytting. Fanø er det eneste unntaket fra dette.

I det midterste kartet ser vi effekten av arbeidsplassveksten. De områdene som har hatt best nettoinnflytting, har også i stor grad hatt høyest arbeidsplassvekst. Men vi ser at kommuner som Esbjerg og Herning har hatt god arbeidsplassvekst, selv om flyttetallene er svake.

I det høyre kartet ser vi brutto bostedsattraktivitet. Det er et mål for om kommunen tiltrekker seg innbyggere utover det som kan forventes av arbeidsplassveksten alene. Mønstrene er omtrent de samme i alle kartene. Områdene som har høy innflytting, har stort sett også høy arbeidsplassvekst, men de trekker også til seg innbyggere i større grad enn hva som er forventet ut fra arbeidsplassveksten.

Dermed ser det ut til at flyttemønstrene i Danmark også i sterk grad blir påvirket av strukturelle flyttefaktorer, noe som vi så i Norge og Sverige også.

Vi skal bruke de samme strukturelle flyttefaktorene som vi avdekket for norske og svenske kommuner, for å forklare den delen av flyttemønstrene i danske kommuner som ikke blir forklart av arbeidsplassveksten. 


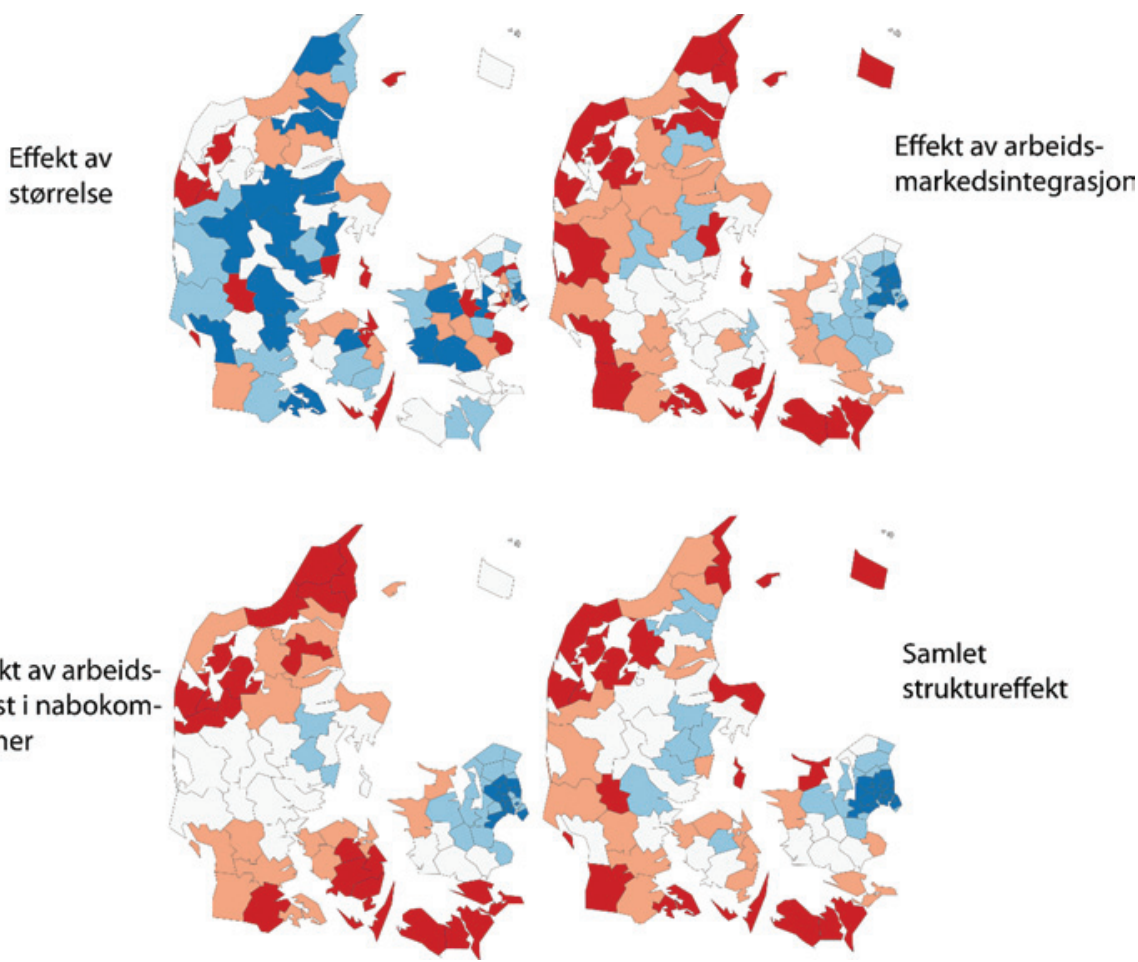

Figur 4.35 Beregnet effekt av kommunenes størrelse (innbyggertall), arbeidsmarkedsintegrasjon og arbeidsplassvekst i nabokommuner i danske kommuner i perioden 2011-2014. I kartet nederst til høyre er effekten av alle de tre strukturelle flyttefaktorene summert.

I kartet øverst til venstre i figur 4.35 ser vi hvordan kommunenes størrelse, målt i innbyggertall, påvirker nettoflyttingen. Kommuner med mange innbyggere trekker til seg innflytting i større grad enn små kommuner, selv om arbeidsplassveksten er den samme. Danske kommuner varierer mindre med hensyn til innbyggertall enn svenske og spesielt norske. Derfor forklarer størrelse mindre av flyttemønstrene.

Kombinasjonen av størrelse og arbeidsmarkedsintegrasjon er et mål på hvor mange arbeidsplasser det er i pendlingsavstand. I store kommuner, eller i kommuner som har høy arbeidsmarkedsintegrasjon, vil en innbygger kunne nå et stort antall potensielle arbeidsplasser. Det kan være en forklaring på hvorfor flere flytter til slike områder. I små kommuner med lav arbeidsmarkedsintegrasjon er valgmulighetene for arbeid langt mindre.

Naboveksten er en faktor som varierer over tid. Mange kommuner i Københavnregionen har sterk vekst i kommuner det pendles til. Sterk vekst i København forklarer nok mye av dette. 
I det siste kartet har vi summert effekten av de strukturelle flyttefaktorene. Her ser vi et ganske tydelig mønster, der kommuner i nærheten av København har de mest positive strukturelle flyttefaktorene. Alle mørkeblå kommuner, det vil si kommuner med de mest gunstige betingelsene for å få innflytting, er i nærheten av København. I gruppen med kommuner i nest mest gunstige kategori finner vi blant annet Aalborg, Aarhus og Odense. Periferien har klart svakest betingelser for å få netto innflytting.

I figur 4.36 skal vi oppsummere analysen av flyttemønstrene i kommunene i Danmark. Nettoflyttingen til danske kommuner ser vi i kartet øverst til venstre. Effekten av arbeidsplassveksten i egen kommune er vist øverst til høyre. Summen av de strukturelle flyttefaktorene er nederst til venstre, og, til slutt, er kommunenes bostedsattraktivitet vist nederst til høyre.

I Danmark virker de to drivkreftene for flytting - arbeidsplassvekst i egen kommune og strukturelle faktorer - i stor grad i samme

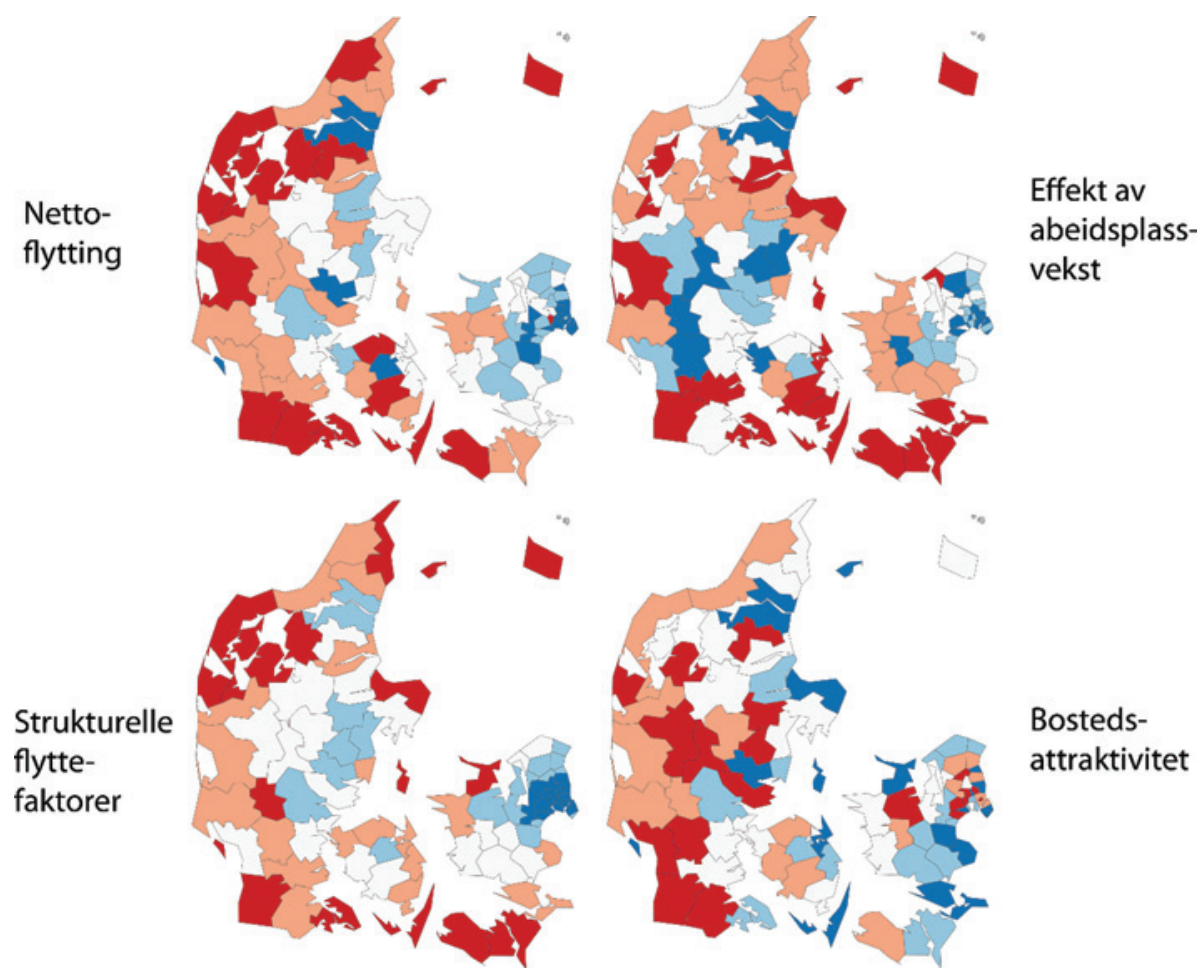

Figur 4.36 Variasjon i nettoflytting, effekten av arbeidsplassvekst i egen kommune, sum strukturelle flyttefaktorer og bostedsattraktivitet i danske kommuner i perioden 2011-2014. 
sentraliserende retning. En del av flyttingen fra periferi til sentrum av Danmark kan forklares av disse to drivkreftene. Kartet med bostedsattraktivitet viser imidlertid også et mønster der periferien i Danmark også har den laveste bostedsattraktiviteten. De objektive størrelsene vi har lagt inn i modellen, forklarer dermed ikke den sterke sentraliseringen som har vært i Danmark de siste årene.

Kartet som viser variasjonene i bostedsattraktivitet, viser imidlertid at det er noen kommuner i periferien med høy bostedsattraktivitet. Øyene er blant de mest attraktive. Fanø, Læsø, Ærø, Samsø og Langeland er alle i kategorien mest attraktive kommuner.

\subsubsection{De mest og minst attraktive bostedskommunene}

\section{i Danmark}

Fanø, Samsø og Læsø har vært mest attraktive som bosteder i perioden 2011-2014. Lista over de mest attraktive kommunene i Danmark har også med øyene Ærø og Langeland. Ingen av disse fem kommunene har hatt

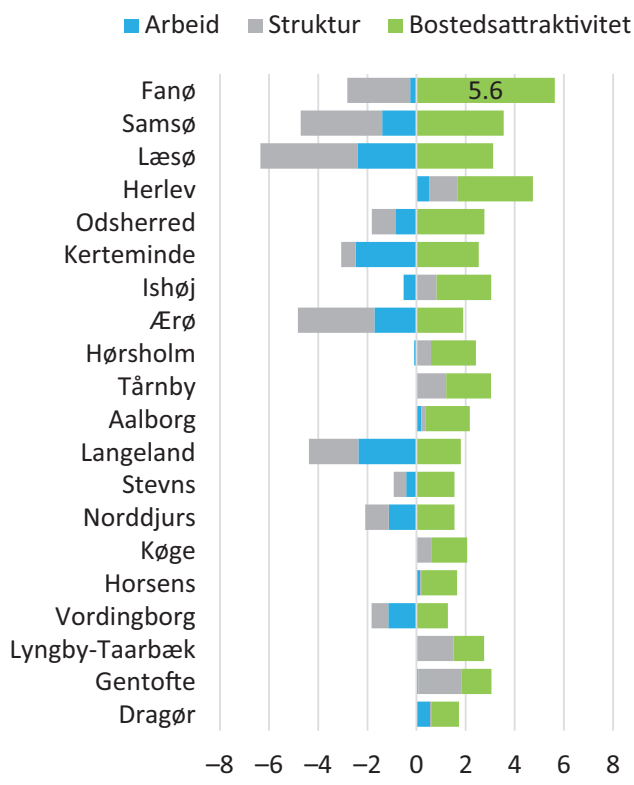

Figur 4.37 Kommunene med høyest bostedsattraktivitet i perioden 2011-2014. 


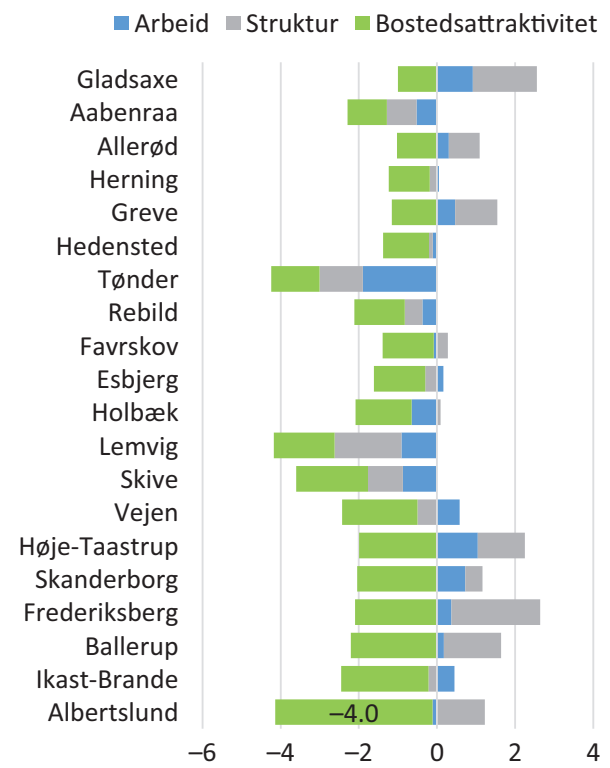

Figur 4.38 Kommunene med lavest bostedsattraktivitet i perioden 2011-2014.

arbeidsplassvekst over landsgjennomsnittet for Danmark i perioden. Kommunene har heller ikke heldige strukturelle flyttebetingelser, fordi de er relativt små kommuner med lav arbeidsmarkedsintegrasjon.

Københavnregionen har en del kommuner med både blant de mest attraktive og blant de minst attraktive. Denne regionen er kjennetegnet av et felles arbeidsmarked som er tett integrert, samtidig som det har vært sterk vekst i antall arbeidsplasser. I likhet med hovedstadsregionene i Norge og Sverige, har bostedsattraktiviteten variert sterkt mellom kommunenei Københavnregionen. Sannsynligvis reflekterer dette at kommunene er ganske ulike med hensyn til å ha arealer som er tilgjengelige for boligbygging. I noen kommuner er det ikke tilgjengelig arealer for boligbygging, og dermed kan ikke kommunen realisere sitt potensial for innflytting og befolkningsvekst. Slike kommuner vil da komme ut med lav bostedsattraktivitet fordi nettoflyttingen er lavere enn forventet. Innflyttingen til regionen blir dermed presset inn i kommuner hvor det bygges boliger, og slike kommuner vil dermed komme ut som svært attraktive. Tilgjengelighet for boliger, spesielt nye boliger, er en faktor som har stor betydning for bostedsattraktiviteten. 
Kommuner som Skive, Lemvig, Rebild, Tønder og Aabenraa er kommuner som har svake strukturelle flyttebetingelser, lav arbeidsplassvekst og lav bostedsattraktivitet på samme tid.

\subsubsection{Næringsutvikling i Danmark}

I kartene i figur 4.39 ser vi effekten av de strukturelle forholdene på arbeidsplassveksten i næringslivet i kommunene i Danmark. Det er bransjeeffekten og befolkningseffekten.

Bransjeeffekten er et resultat av at bransjestrukturen i kommunen avviker fra landsgjennomsnittet. Noen kommuner har en stor del av næringslivet i bransjer med vekst, mens andre kommuner har et næringsliv som er konsentrert til bransjer med nedgang. I denne perioden har det vært nedgang i mange industribransjer i Danmark. Tjenesteytende næringer har hatt vekst. Mange av kommunene i perifere områder har en forholdsvis liten andel av næringslivet i tjenesteyting og en tilsvarende stor andel i tradisjonell industri. Det gir en negativ bransjeeffekt. De største byene har lite av industri, men mye av bransjer som teknologisk og forretningsmessig tjenesteyting. De største byene har dermed en positiv bransjeeffekt.

Befolkningseffekten bestemmes av befolkningsutviklingen sammen med andelen av næringslivet i befolkningsfølsomme bransjer, som handel, servering, bygg og anlegg. Befolknings- og bransjeeffekten i denne perioden har hatt omtrent samme mønster. Den samlede struktureffekten er vist i kartet til høyre.

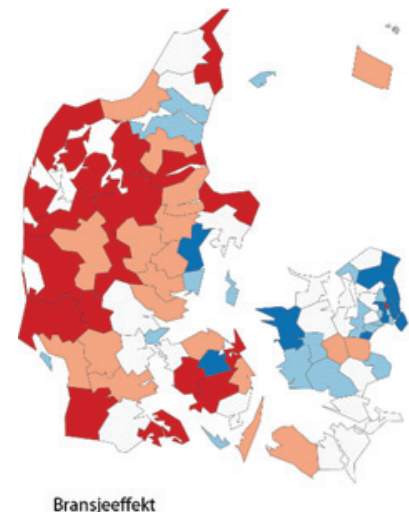

Bransjeeffekt

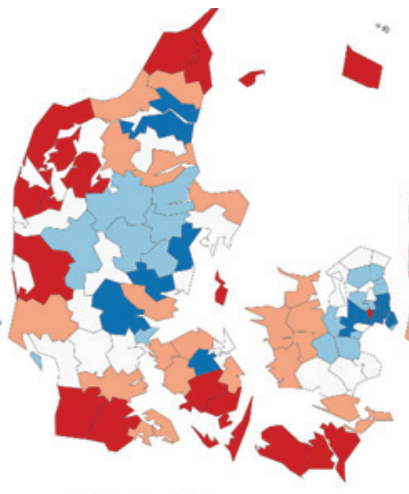

Befolkningseffekt

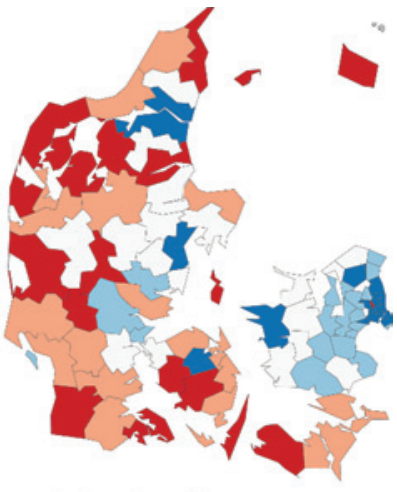

Samlet struktureffekt

Figur 4.39 Bransjeeffekten, befolkningseffekten og samlet struktureffekt på arbeidsplassutviklingen i næringslivet i danske kommuner i perioden 2011-2014. 


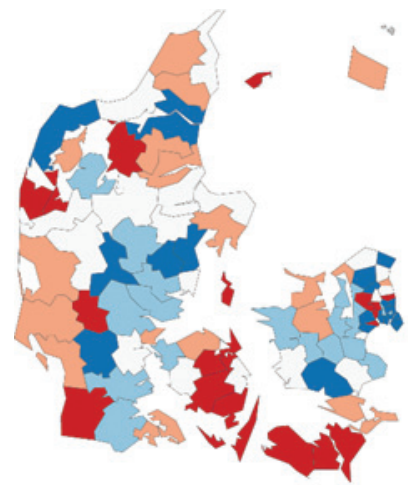

Arbeidsplassvekst i næringslivet

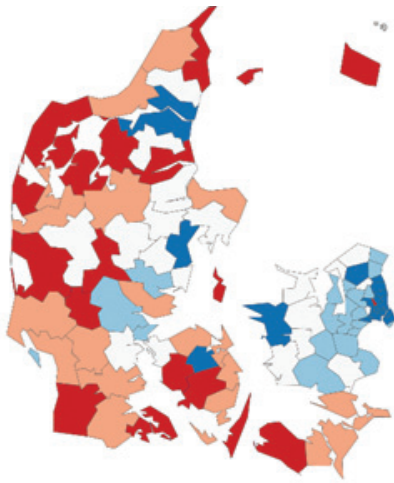

Strukturelle forhold

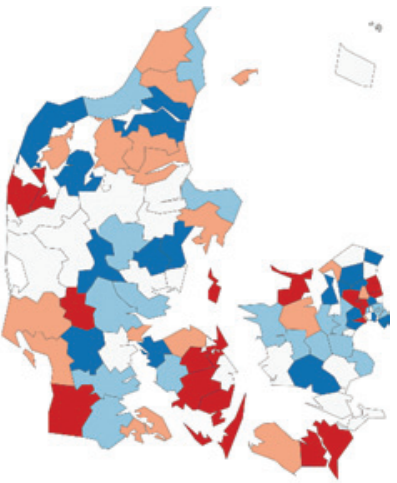

Næringsattraktivitet

Figur 4.40 Variasjoner i arbeidsplassvekst i næringslivet, strukturelle forhold for vekst og næringsattraktivitet i danske kommuner i perioden 2009-2014.

Den samlede struktureffekten vil også være den forventede veksten i næringslivet i de ulike kommunene.

Nå kan vi sammenlikne den faktiske arbeidsplassveksten i næringslivet med den forventede veksten. Den forventede veksten vil være bestemt av de to strukturelle forholdene vi omtalte på forrige side: bransjestrukturen og befolkningsveksten.

Kartet med arbeidsplassvekst til venstre i figur 4.40 likner det midterste kartet, men det er en del kommuner hvor det er avvik. Disse avvikene er interessante. Noen kommuner har fått en bedre næringsutvikling enn forventet ut fra de strukturelle betingelsene.

Det siste kartet viser avviket mellom faktisk og forventet arbeidsplassvekst. Det bruker vi som indikator for næringsattraktivitet. Kommuner der arbeidsplassveksten i næringslivet har vært høyere enn forventet, har vært attraktive for næringsliv i perioden.

Det er ingen spesielle og tydelige mønstre i næringsattraktiviteten. Det skal det i prinsippet heller ikke være, fordi de strukturelle faktorene er «renset bort». Vi skal se hvilke kommuner som har vært spesielt attraktive, og hvem som har vært lite attraktive, på neste side.

\subsubsection{Mest attraktive kommuner for næringsliv}

Gladsaxe har høyest næringsattraktivitet av de danske kommunene i årene 2011-2014. Samtidig var Lyngby-Taarbæk den minst attraktive 


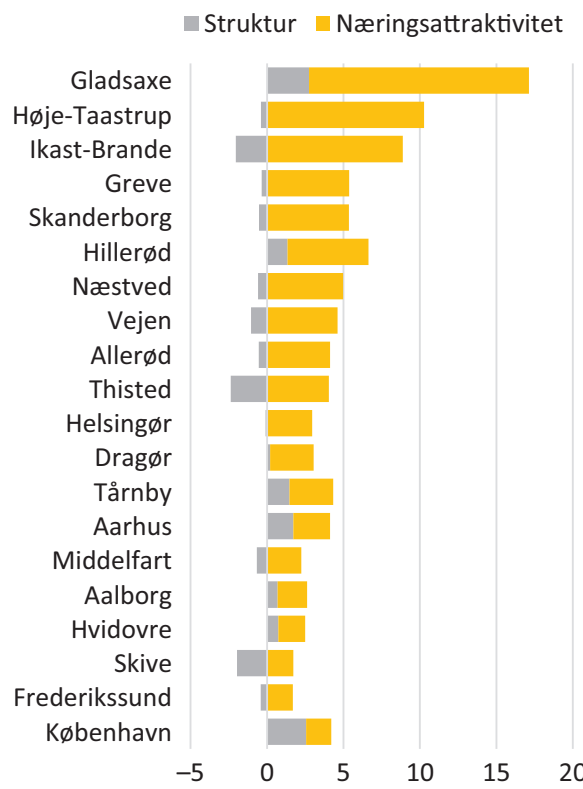

Figur 4.41 De mest attraktive næringskommunene i Danmark i perioden 2011-2014. Benevningen er prosent av samlet sysselsetting.

næringskommunen. Disse to kommunene ligger begge i Københavnregionen, og de grenser til hverandre. Siden den enes attraktivitet er motsatt av den andre, kan det se ut som om en større bedrift har flyttet fra den ene til den andre i perioden.

Kommuner som Ikast-Brande, Thisted og Skive er kommuner som har hatt lite gunstige strukturelle forhold, men som likevel har greid å skape vekst i næringslivet.

København er med blant de 20 mest attraktive næringskommunene i Danmark i denne perioden. København har også hatt gunstige strukturelle betingelser for vekst. Det har skapt sterk vekst i antall arbeidsplasser i næringslivet i København og bidratt til befolkningsvekst i hele regionen.

\subsubsection{De minst attraktive næringskommunene}

Øykommunene Langeland, Ærø og Fanø var blant de mest attraktive bostedskommunene i Danmark, men er samtidig blant de minst attraktive næringskommunene. 


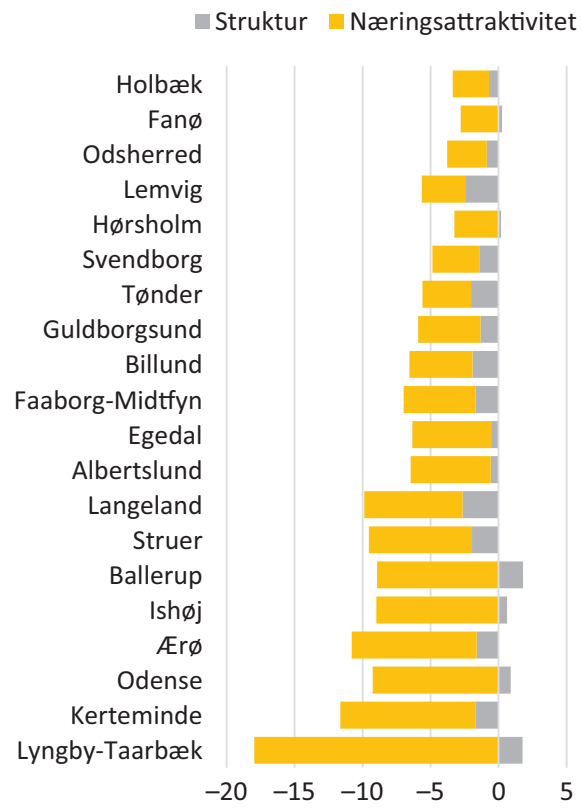

Figur 4.42 De minst attraktive næringskommunene i Danmark i perioden 2011-2014. Benevningen er prosent av samlet sysselsetting.

\subsubsection{Samlet attraktivitet}

Vi kan kombinere tallene for bosteds- og næringsattraktivitet for å få et mål for samlet attraktivitet. Vi bruker den samme metoden som vi brukte på norske kommuner og svenske kommuner tidligere.

Den horisontale aksen viser den samlede struktureffekten. København har den mest gunstige samlede struktureffekten av alle kommunene. Forventet relativ netto innflytting til København er 2,9 prosent i denne fireårsperioden. København har hatt en innflytting som ligger tett opp til forventet verdi.

Læsø har de minst gunstige strukturelle betingelsene, og har en forventet relativ nettoinnflytting på -4,8 prosent. Øyene Fanø, Samsø og Læsø er kommuner med lite gunstige strukturelle forhold, men de har hatt langt bedre nettoinnflytting enn forventet.

Gladsaxe, Tårnby og Herlev er kommuner med gunstige strukturelle betingelser som i tillegg har økt veksten gjennom høy samlet attraktivitet. 


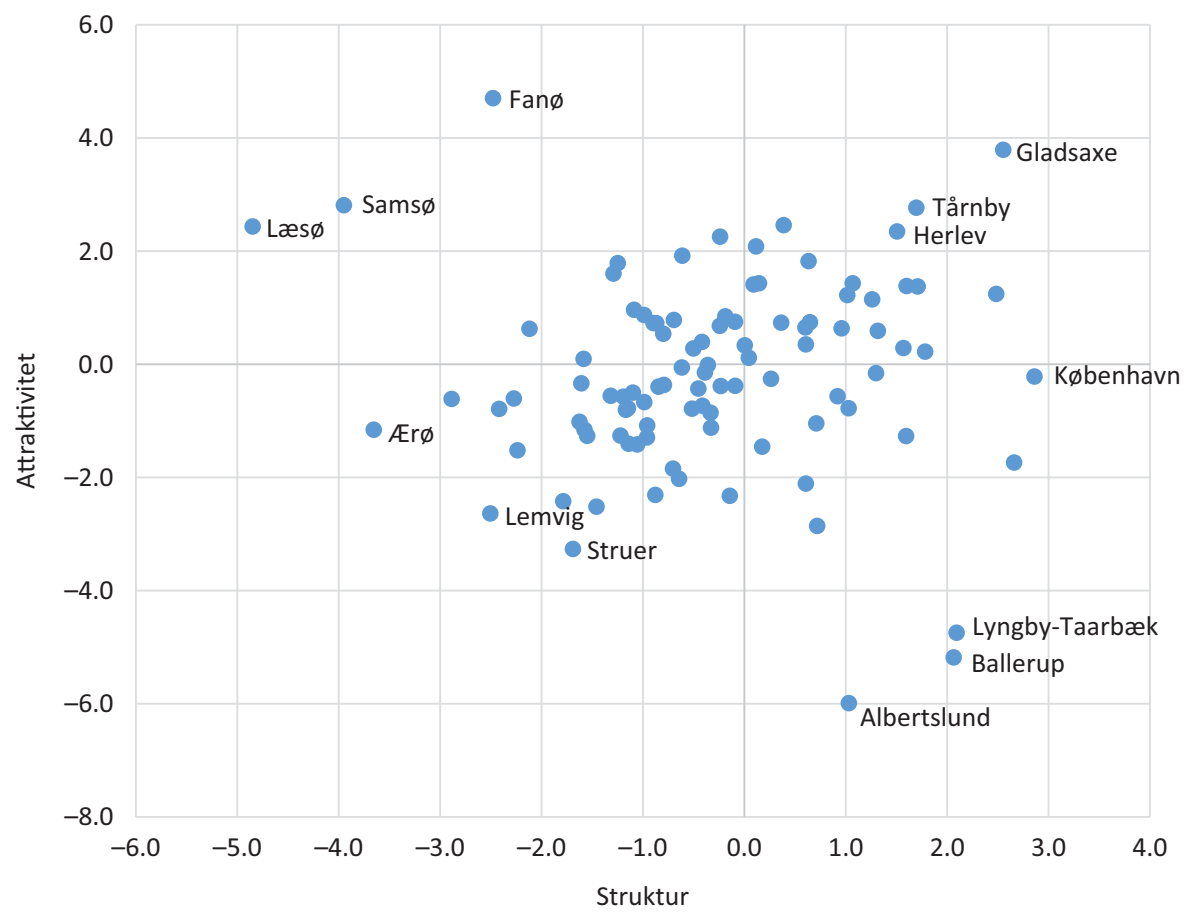

Figur 4.43 Samlet struktureffekt og samlet attraktivitet i danske kommuner i perioden 2011-2014.

Albertslund, Ballerup og Lyngby-Taarbæk er kommuner med gunstige strukturelle betingelser, men som ikke har fått realisert vekstpotensialet fordi attraktiviteten har vært lav.

Ærø, Lemvik og Struer har den uheldige kombinasjonen av lav attraktivitet og lite gunstige vekstbetingelser.

\subsubsection{Danmarks mest og minst attraktive kommuner}

Når vi kombinerer attraktiviteten for bosted og næringsliv, er det Fanø, Gladsaxe og Samsø som samlet sett har vært mest attraktive i perioden 2009-2014.

Kommuner som Gladsaxe, Høje-Taastrup og Hillerød har all sin attraktivitet fra næringsattraktivitet, mens bostedsattraktiviteten har vært negativ. Fanø, Samsø, Læsø, Herlev og Odsherred har høy attraktivitet som bosted, men er lite attraktive som næringssteder. 


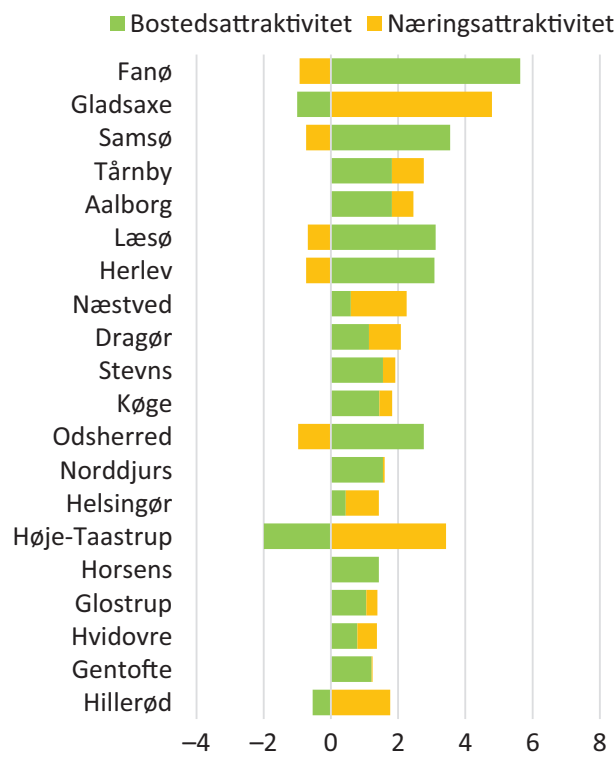

Figur 4.44 De mest attraktive kommunene i Danmark i perioden 2011-2014.

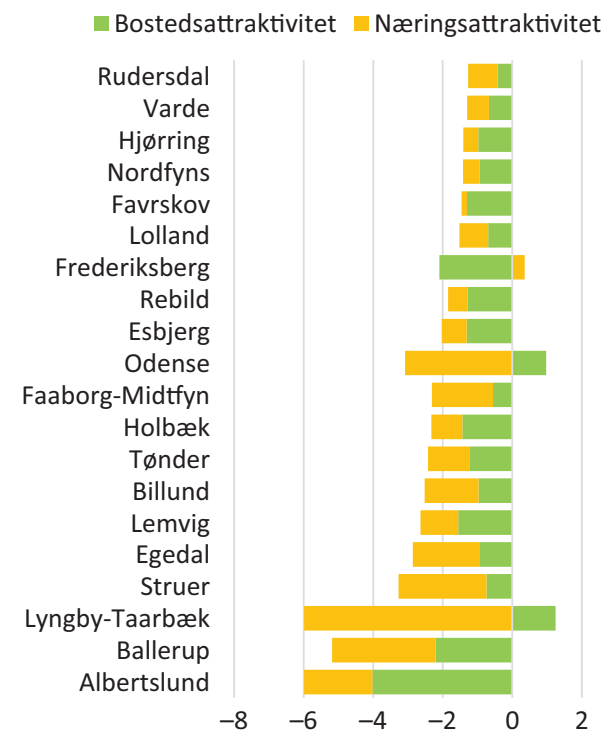

Figur 4.45 De minst attraktive kommunene i Danmark i perioden 2011-2014. 
Tallene for attraktivitet kan tolkes som hvor mye ekstra innflytting (i prosent av folketallet) som kommunen har fått i perioden. I Fanø har det vært en netto innflytting som er 5,6 prosent over forventet verdi. Svak næringsattraktivitet førte imidlertid til en reduksjon av nettoflyttingen på 0,9 prosent. Samlet sett økte Fanø folketallet med 4,7 prosent på grunn av høy attraktivitet i disse fire årene.

De minst attraktive kommunene i perioden er Albertslund, Ballerup og Lyngby-Taasbæk. Alle tre er kommuner i hovedstadsregionen. Struer er den minst attraktive kommunen utenfor hovedstadsregionen.

\subsubsection{Mest attraktive kommune/region i Skandinavia?}

Vi skal starte med å se på mønstre i næringsutviklingen i Skandinavia. I kartene i figur 4.46 ser vi variasjonene i arbeidsplassvekst, forventet arbeidsplassvekst og næringsattraktivitet.

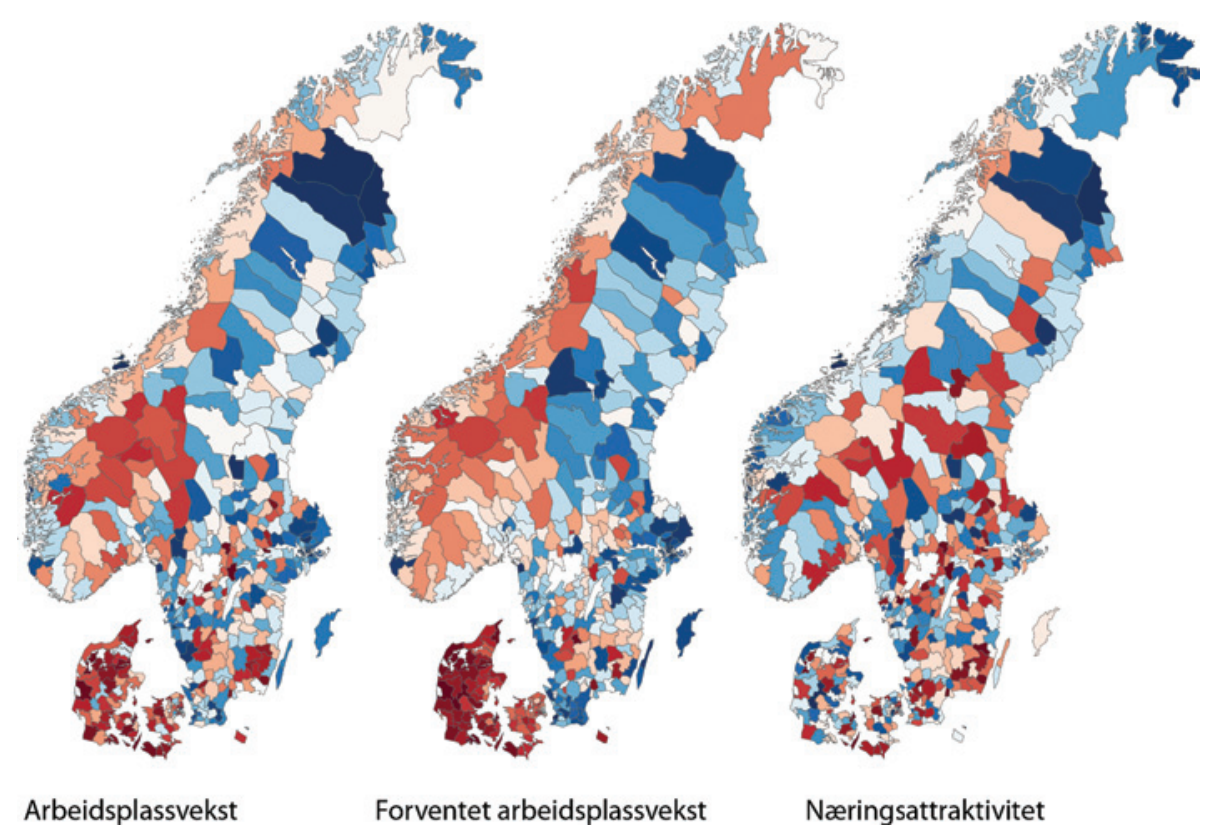

Figur 4.46 Variasjon i arbeidsplassvekst i næringslivet, forventet arbeidsplassvekst og næringsattraktivitet (avvik mellom faktisk og forventet arbeidsplassvekst i næringslivet) i Norge, Sverige og Danmark i perioden 2009-2014. 
Kartet til venstre viser variasjonene i arbeidsplassvekst i næringslivet i perioden fra 2009 til 2014.Vi kan tydelig se at veksten har vært sterkest i Sverige, og da spesielt i de nordlige områdene. Danmark har hatt klart svakest vekst $\mathrm{i}$ denne perioden.

I det midterste kartet ser vi hvilken arbeidsplassvekst vi kan forvente ut fra tre strukturelle forhold: landets gjennomsnittsvekst, bransjeeffekten og befolkningseffekten. Det er klare likheter mellom faktisk og forventet vekst, noe som betyr at modellen har en ganske god forklaringskraft. Mange av kommunene i Nord-Sverige har hatt høy faktisk og forventet arbeidsplassvekst i næringslivet i denne perioden. I Norge er det bare Stavangerregionen, Oslo, Bergen og Trondheimsregionen som har hatt høy forventet vekst i antall arbeidsplasser i næringslivet i denne perioden. Disse fire regionene har imidlertid en vesentlig andel av arbeidsplassene i næringslivet i Norge.

I det siste kartet ser vi variasjonen i næringsattraktivitet i perioden. Siden de strukturelle forholdene er rensket ut av målet for næringsattraktivitet, er det ikke noen klare mønstre i det siste kartet. Det vil være interessant å se hvilke steder som har høyest næringsattraktivitet i Skandinavia.

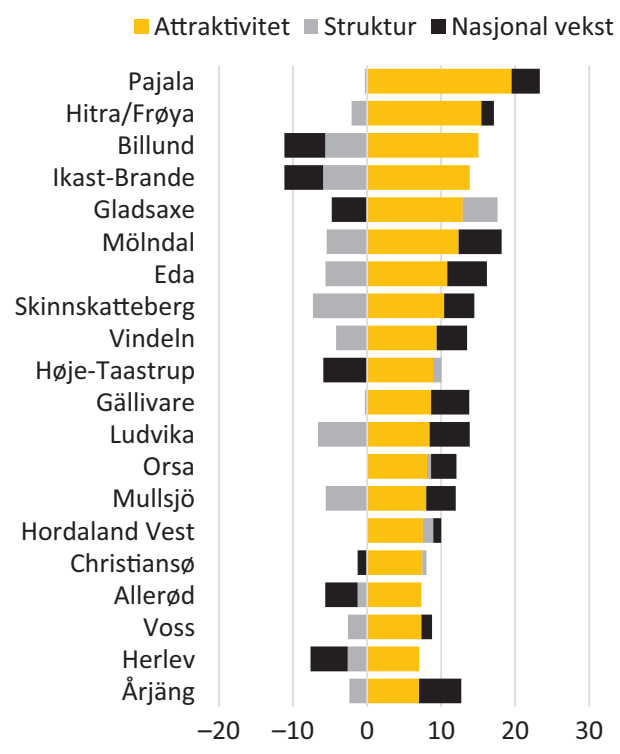

Figur 4.47 Næringsattraktivitet i perioden 2009-2014, sammen med bidrag fra bransjeeffekt og nasjonal vekst. Enheten er prosentvis andel av samlet sysselsetting i kommunen/regionen. De 20 mest attraktive. 


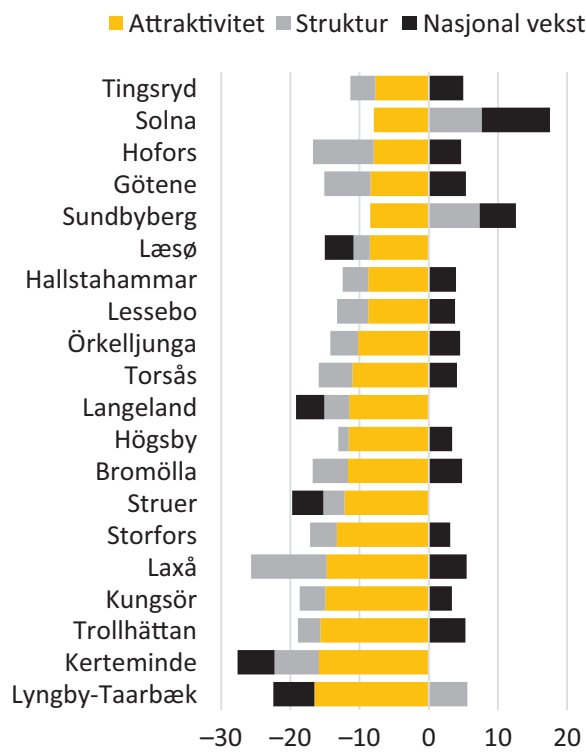

Figur 4.48 Næringsattraktivitet i perioden 2009-2014, sammen med bidrag fra bransjeeffekt og nasjonal vekst. Enheten er prosentvis andel av samlet sysselsetting i kommunen/regionen. De 20 minst attraktive.

\subsubsection{Høyest og lavest næringsattraktivitet i Skandinavia}

Pajala har høyest næringsattraktivitet i Skandinavia i perioden 2009-2014.Den høye næringsattraktiviteten i Pajala kan delvis forklares av sterk vekst i gruvedrift i perioden. Dessverre for Pajala gikk gruveselskapet konkurs i 2014, dermed vil Pajala neppe toppe statistikken når den oppdateres for 2015 . Regionen Hitra/Frøya har den nest høyeste næringsattraktiviteten i Skandinavia i denne perioden. Hitra/Frøya har også mye av sin attraktivitet knyttet til basisnæringene, og da spesielt havbruk.

De danske kommunene Billund og Ikast-Brande er nummer tre og fire i Skandinavia. Disse kommunene hadde sterk vekst i næringslivet i begynnelsen av perioden. Blant de minst attraktive næringskommunene er det ingen norske.

\subsubsection{Skandinaviske bostedsmønstre}

Regionene i Norge har høyest faktisk og forventet nettoflytting i denne perioden. Det er på grunn av at Norge har hatt høyest netto innvandring. Det er i 


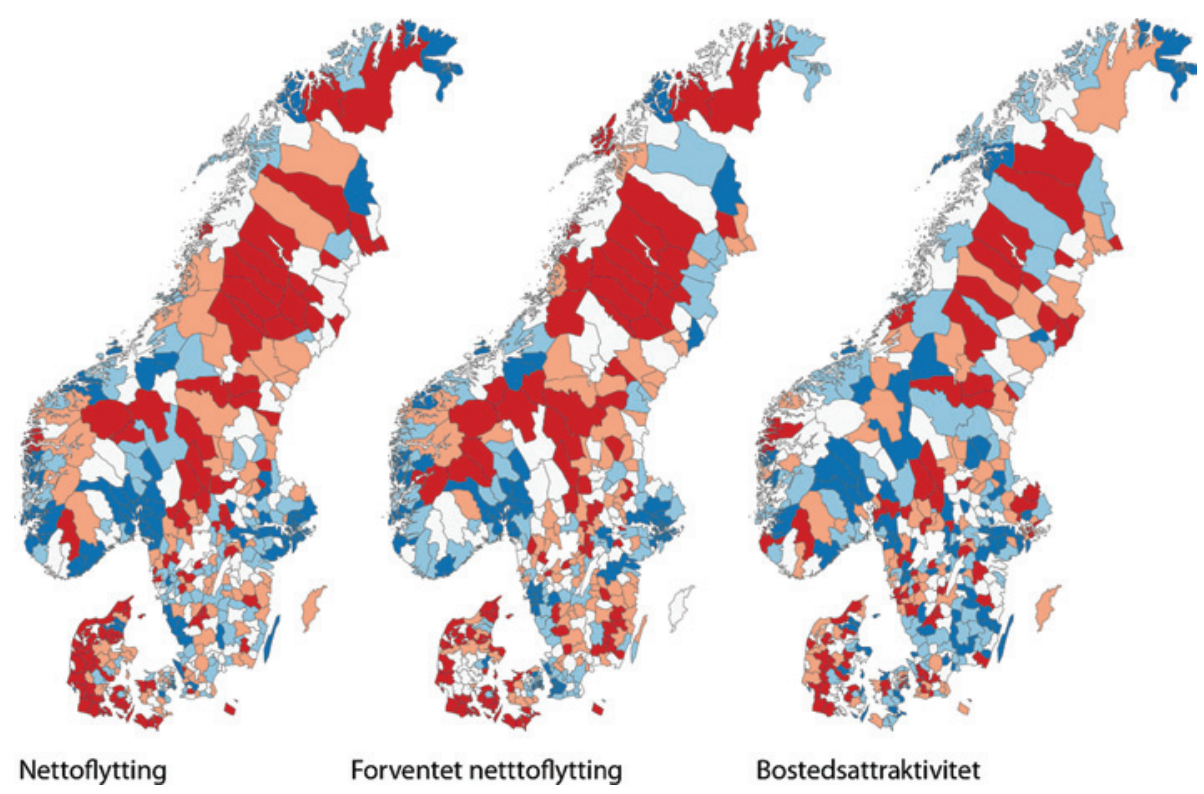

Figur 4.49 Nettoflytting, forventet nettoflytting og bostedsattraktivitet i norske regioner og svenske og danske kommuner i perioden 2011-2014.

ferd med å endres, ettersom innvandringen til Norge avtar, mens den øker i Sverige og Danmark.

Norge har også større spredning i bostedsattraktiviteten. I Norge har mange regioner i distriktene høy bostedsattraktivitet. I Sverige og særlig i Danmark kan det se ut til at kommuner i periferien har lavere bostedsattraktivitet. Vi kan se at det er mange røde kommuner i Nord-Sverige og Vest-Danmark. I Norge har mange regioner i nord en relativt høy bostedsattraktivitet etter skandinavisk skala.

Det er ikke sikkert at den høye bostedsattraktiviteten i nord kan tas til inntekt for en mer vellykket distriktspolitikk i Norge. Det kan også være et resultat av at Norge har hatt høyest netto innvandring i denne perioden. Innvandrerne har et mer «distriktsvennlig» flyttemønster enn det som framkommer i den innenlandske flyttingen. Når den innenlandske flyttingen betyr relativt mer i Danmark og Sverige enn i Norge, vil det også bli et mer sentraliserende flyttemønster av den grunn. 


\subsubsection{Høyest og lavest bostedsattraktivitet $\mathrm{i}$ Skandinavia}

Den danske øykommunen Fanø har høyest bostedsattraktivitet i Skandinavia i perioden 2011-2014. De svenske kommunene Strömstad og Fagersta er nummer to og tre. De norske regionene Hitra/Frøya og Bjørnefjorden er nummer 18 og 20 i Skandinavia.

For noen faller høy bostedsattraktivitet sammen med høy arbeidsplassvekst, som i Strömstad, Herlev, Sigtuna, Knivsta og Hitra/Frøya.

I kommuner som Sundbyberg, Herlev, Sigtuna og Knivsta er de strukturelle flyttefaktorene også positive. Slike kommuner vil naturligvis oppleve den høyeste nettoinnflyttingen. I kommuner som den danske øykommunen Læsø er arbeidsplassveksten lav samtidig som de strukturelle betingelsene for tilflytting er lite gunstige. Læsø har dermed ikke fått netto tilflytting, men attraktiviteten har ført til at utflyttingen har blitt begrenset.

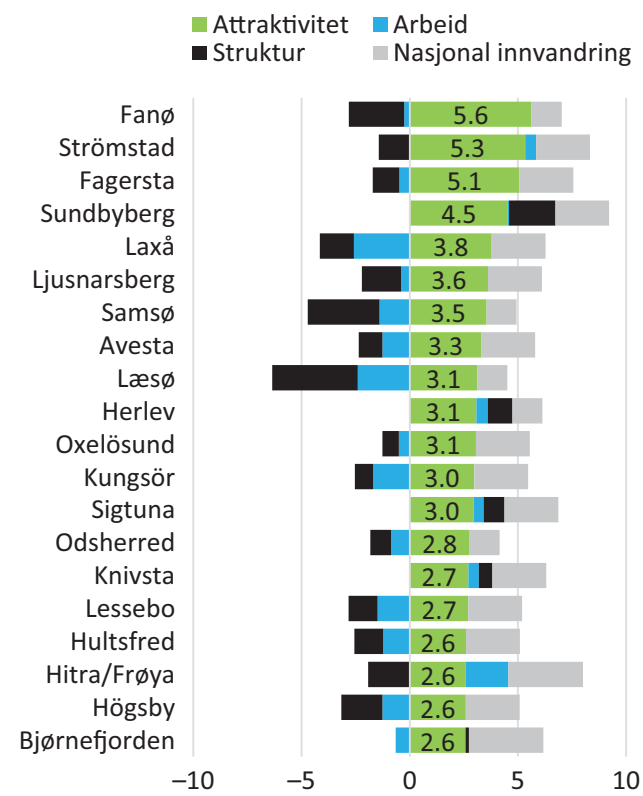

Figur 4.50 Bostedsattraktivitet i perioden 2011-2014, sammen med bidrag fra arbeidsplassvekst, struktur og nasjonal innvandring. Enheten er nettoflytting i prosent av folketallet. 


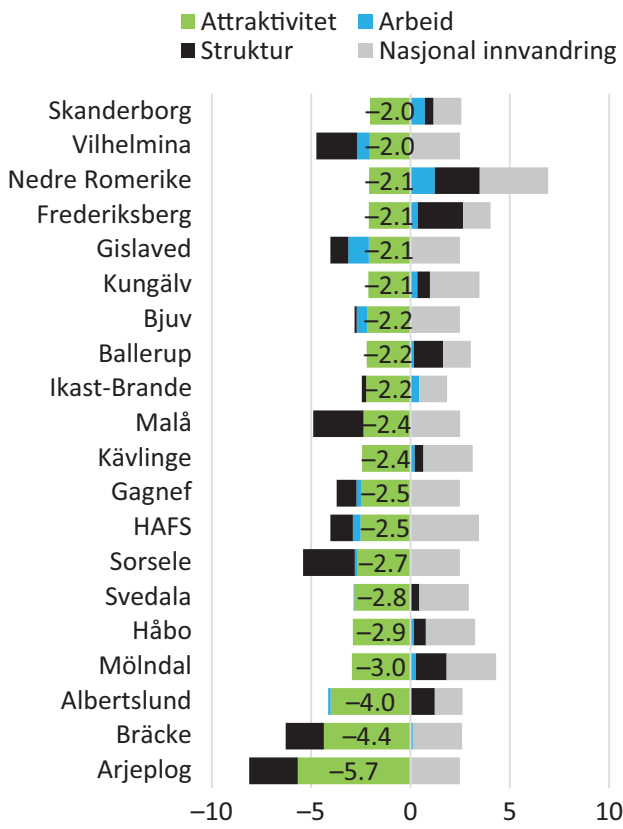

Figur 4.51 Bostedsattraktivitet i perioden 2011-2014, sammen med bidrag fra arbeidsplassvekst, struktur og nasjonal innvandring. Enheten er nettoflytting i prosent av folketallet.

De svenske kommunene Bräcke og Arjeplog er minst attraktive som bosted i Skandinavia.

På lista over de minst attraktive finner vi også de norske regionene HAFS (ytterst i Sognefjorden) og Nedre Romerike. Nedre Romerike er en region med sterk vekst, som følge av høy arbeidsplassvekst og gunstig beliggenhet, men skulle statistisk sett hatt en enda høyere netto tilflytting. I figurene ser vi også bidraget fra den nasjonale nettoinnvandringen. Det er høyest i de norske regionene og lavest i de danske kommunene.

\subsubsection{Samlet attraktivitet Skandinavia}

Kartet til venstre i figur 4.52 viser den samlede struktureffekten i Skandinavia. Den er et resultat av de strukturelle faktorene for flytting og de strukturelle faktorene for arbeidsplassvekst i næringslivet. Områdene rundt de største byene har både gunstige strukturelle flyttebetingelser og en gunstig næringsstruktur. 


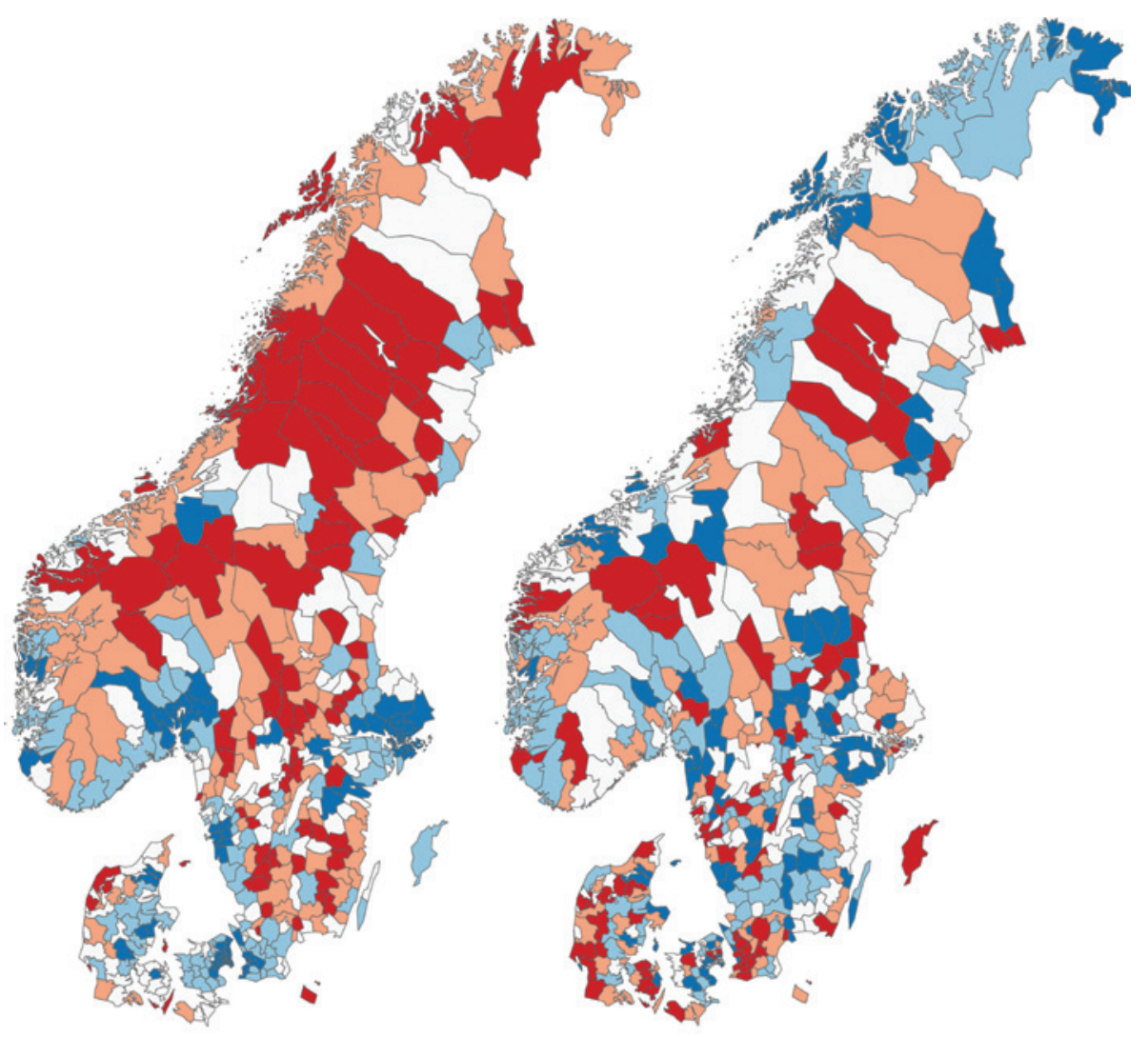

Samlet struktureffekt

Samlet attraktivitet

Figur 4.52 Samlet struktureffekt og samlet attraktivitet i perioden 2011-2014.

Vi kan se at områdene med de beste strukturelle vekstbetingelsene i Norge er rundt de fire største byene: Oslo, Stavanger, Bergen og Trondheim. Liknende mønster finner vi i Sverige og Danmark.

Kartet med samlet attraktivitet viser, som ventet, ingen sterke regionale mønstre. I Norge er mange av regionene i nord attraktive. I Sverige og Danmark kan det se ut til at kommuner i periferien er mindre attraktive. 


\section{Scenariomodellen}

Attraktivitetsmodellen kan også brukes til å lage scenarioer og framskrivinger av befolkning og arbeidsplasser i kommuner, regioner og fylker. Analysene av utviklingen de siste årene forteller oss hvordan sammenhengene har vært. Dette gir oss estimater for mange av parametrene (betaverdiene fra regresjonsanalysene) som vi trenger for å bruke modellen for å beregne framtidig utvikling. Vi skal forsøke å presentere attraktivitetsmodellen på en grafisk og intuitiv måte. Modellen er vist i figur 4.53

Når vi brukte modellen for å analysere drivkreftene i den historiske utviklingen, la vi inn data og beregnet sammenhengene. Når vi skal bruke modellen for å beregne framtidig utvikling, forutsetter vi at sammenhengene (betaverdiene) vi fant i analysene av de siste årene, skal gjelde for de neste årene.

Vi forutsetter dermed følgende:

- Sammenhengen mellom arbeidsplassvekst og nettoflytting vil fungere på samme måte i framtiden som $i$ fortiden.

- Bransjene og sektorene som var påvirket av befolkningsveksten i fortiden, vil bli påvirket av befolkningsveksten på samme måte i framtiden.

- De strukturelle flyttefaktorene vil påvirke nettoflyttingen på samme måte i framtiden som den har gjort i de siste årene.

Dette er illustrert med de blå pilene i figuren.

Vi antar at arbeidsplassutviklingen på steder også i framtiden blir påvirket av hvordan den nasjonale veksten fordeler seg på bransjer og sektorer. Vi har imidlertid ikke noen modell for hvordan denne veksten blir. Vi trenger derfor et grunnlag for å legge inn forventet arbeidsplassvekst $\mathrm{i}$ bransjer og sektorer $\mathrm{i}$ framtiden. Dette har vi gjort i to trinn. Det første trinnet har vært å beregne samlet vekst i antall arbeidsplasser i Norge. Det andre trinnet har vært å forsøke å fordele denne veksten på bransjer og sektorer.

Samtidig må vi legge inn forutsetninger om Norges samlede innvandring i framtiden og fødselsbalansen. Til dette har vi brukt SSBs framskrivinger over sannsynlig utvikling av befolkningsveksten i Norge. Her finner vi forventet nettoinnvandring til Norge og fødselsbalansen de neste årene. 


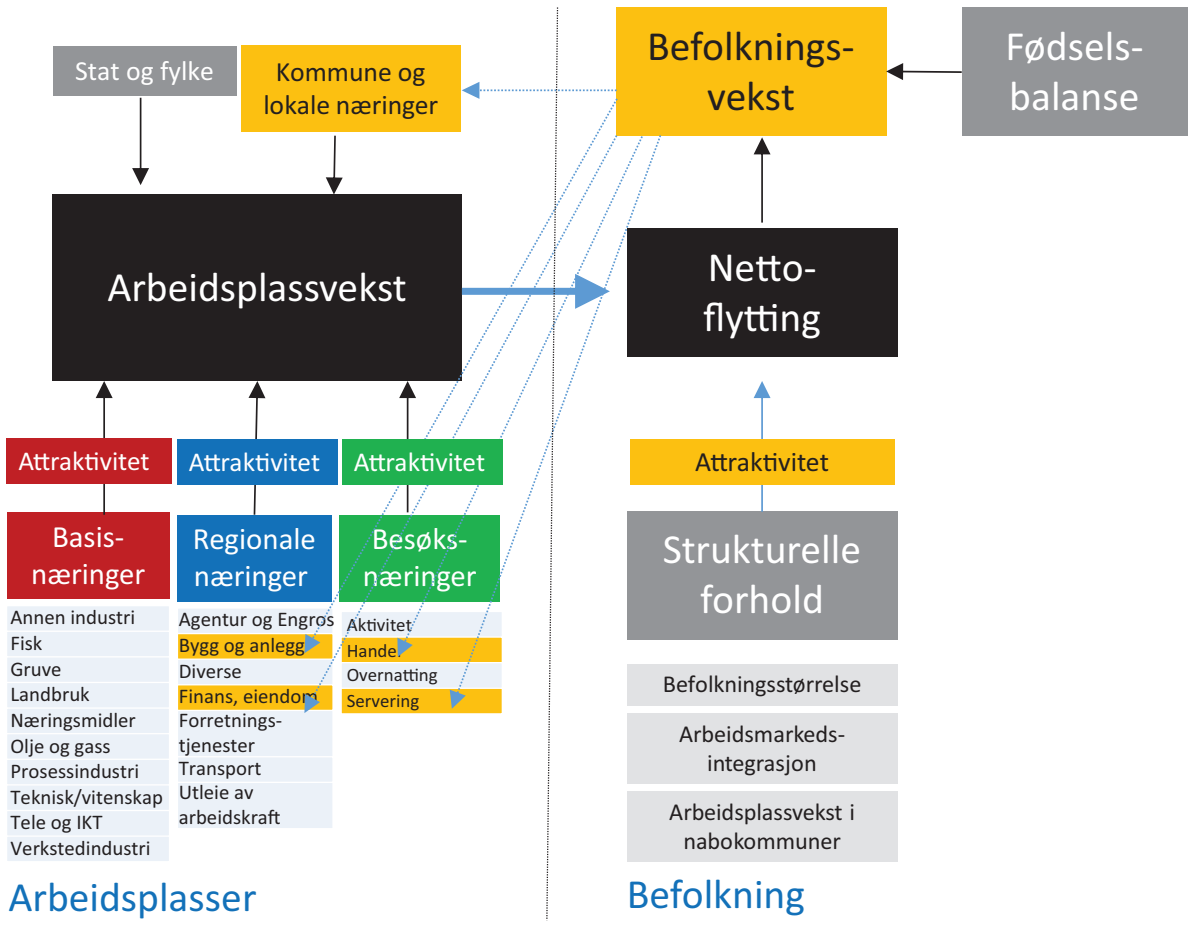

Figur 4.53 Skisse for attraktivitetsmodellen.

I scenariomodellen har vi lagt inn en forutsetning om at samlet arbeidsplassvekst i Norge skal samsvare med befolkningsveksten. Det er det samme som at vi forutsetter at sysselsettingsandelen skal forbli den samme. Sysselsettingsandelen i Norge har vært ganske konstant i mange år. Den blir høyere i oppgangskonjunkturer og lavere når det er nedgangskonjunkturer, men har forandret seg lite over tid. En forutsetning om at sysselsettingsandelen skal være konstant, er dermed ikke urealistisk. Det som forandrer seg, er hvordan befolkningen fordeler seg på ulike alderstrinn. Vi har derfor antatt at sysselsettingsandelen opprettholdes innenfor hvert alderstrinn.

I figur 4.54 viser vi historiske årlige vekstrater i arbeidsplassveksten, sammen med forventede årlige vekstrater. I de forventede vekstratene antar vi at veksten i antall arbeidsplasser blir lik veksten i folketallet. Vi ser at antall arbeidsplasser i Norge økte fra 2,25 mill. i 2000 til 2,63 mill. i 2014. Prognosen viser en videre vekst fram til 2,94 mill. i 2030. Stolpene viser den årlige vekstraten. 


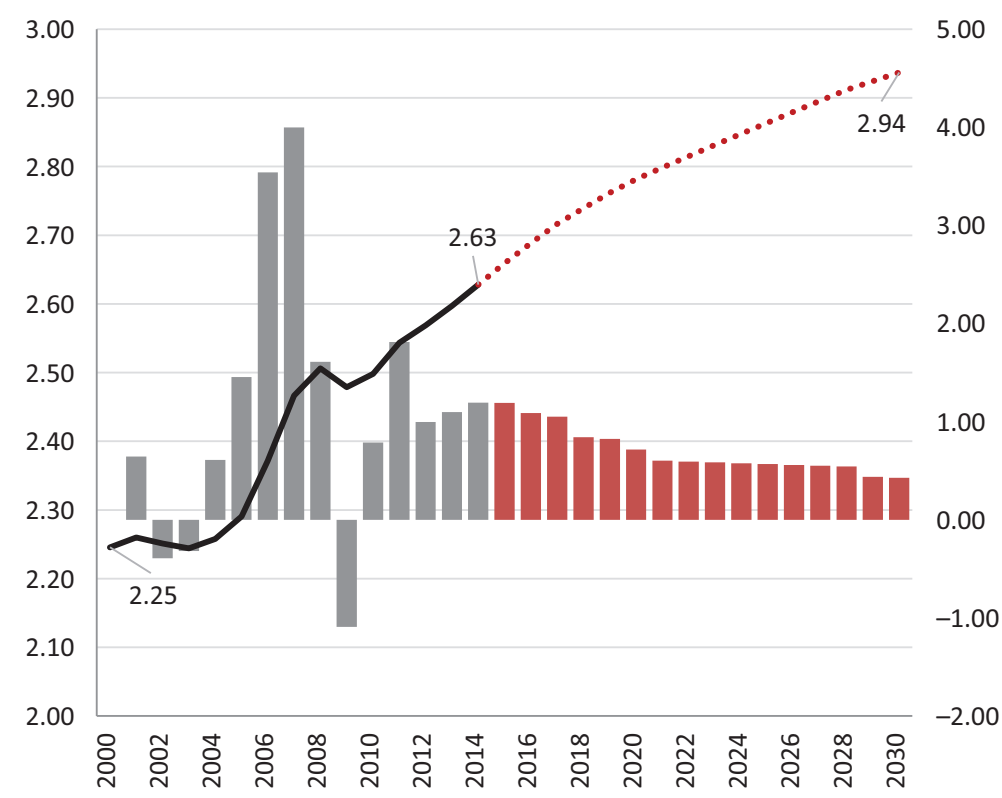

Figur 4.54 Arbeidsplassveksten i Norge fram til 2014, og beregnet arbeidsplassvekst fram til 2030. Oppdatert 2015.

Når vi ser de historiske vekstratene, ser vi tydelig at de svinger ganske sterkt med konjunkturene. I scenarioene legger vi inn en jevn vekst. Det kommer naturligvis til å bli konjunktursvingninger i framtiden også, men disse har vi ikke mulighet til å forutse med noen grad av sannsynlighet. Et tydelig trekk er at arbeidsplassveksten vil bli lavere. Det kommer dels av at den samlede befolkningsveksten antas å bli svakere, og dels at en mindre andel av befolkningen kommer til å være i arbeidsaktiv alder.

Vi må også legge inn i modellen hvordan vi forventer at arbeidsplassveksten skal fordele seg mellom ulike bransjer og sektorer. De forutsetningene om årlige vekstrater som er lagt inn i modellen er vist i tabell 4.2.

Vi har basert de framtidige vekstratene på de historiske vekstratene, men med tre unntak: Olje- og gassutvinning, tjenester til olje og gassutvinning og verkstedindustrien er forutsatt å gå fra vekst til nedgang som følge av oljekrisen som inntraff i 2014. For de øvrige bransjene har vi brukt et gjennomsnitt av vekstrater for perioden 2000-2014 som et utgangspunkt. Vi har da brukt et såkalt progressivt gjennomsnitt der de siste årene får høyere vekt. Dernest har 
Tabell 4.2 Årlige vekstrater i perioden 2000-2014 og hva som er forventede årlige vekstrater i perioden 2015-2030. Oppdatert 2015.

\begin{tabular}{|c|c|c|}
\hline & 2000-2014 & 2015-2030 \\
\hline Annen industri & $-2,3$ & $-2,9$ \\
\hline Næringsmidler & $-1,0$ & $-1,1$ \\
\hline Olje og gass, utvinning & 3,6 & $-4,8$ \\
\hline Prosessindustri & $-2,8$ & $-4,3$ \\
\hline Verkstedindustri & 0,2 & $-0,5$ \\
\hline Fisk & $-1,5$ & $-1,6$ \\
\hline Gruve & 0,8 & 0,5 \\
\hline Landbruk & $-2,4$ & $-3,8$ \\
\hline Olje og gass, tjenester & 8,5 & $-4,4$ \\
\hline Teknisk/vitenskap & 4,6 & 2,1 \\
\hline Tele og IKT & 2,6 & 2,1 \\
\hline Aktivitet & 2,0 & 0,8 \\
\hline Handel & 1,0 & 0,1 \\
\hline Overnatting & 0,0 & 0,2 \\
\hline Servering & 1,6 & 1,4 \\
\hline Agentur og engros & 0,2 & $-0,3$ \\
\hline Bygg og anlegg & 3,3 & 2,2 \\
\hline Diverse & 1,4 & 0,4 \\
\hline Finans, eiendom, utleie & 0,5 & $-0,6$ \\
\hline Forr. tjenesteyting & 2,6 & 2,2 \\
\hline Transport & $-0,9$ & $-1,1$ \\
\hline Utleie av arbeidskraft & 3,1 & 1,9 \\
\hline Lokale næringer & 2,9 & 1,8 \\
\hline Kommune & 1,2 & 0,8 \\
\hline Stat & 1,7 & 2,0 \\
\hline Fylke & 0,5 & $-1,0$ \\
\hline
\end{tabular}




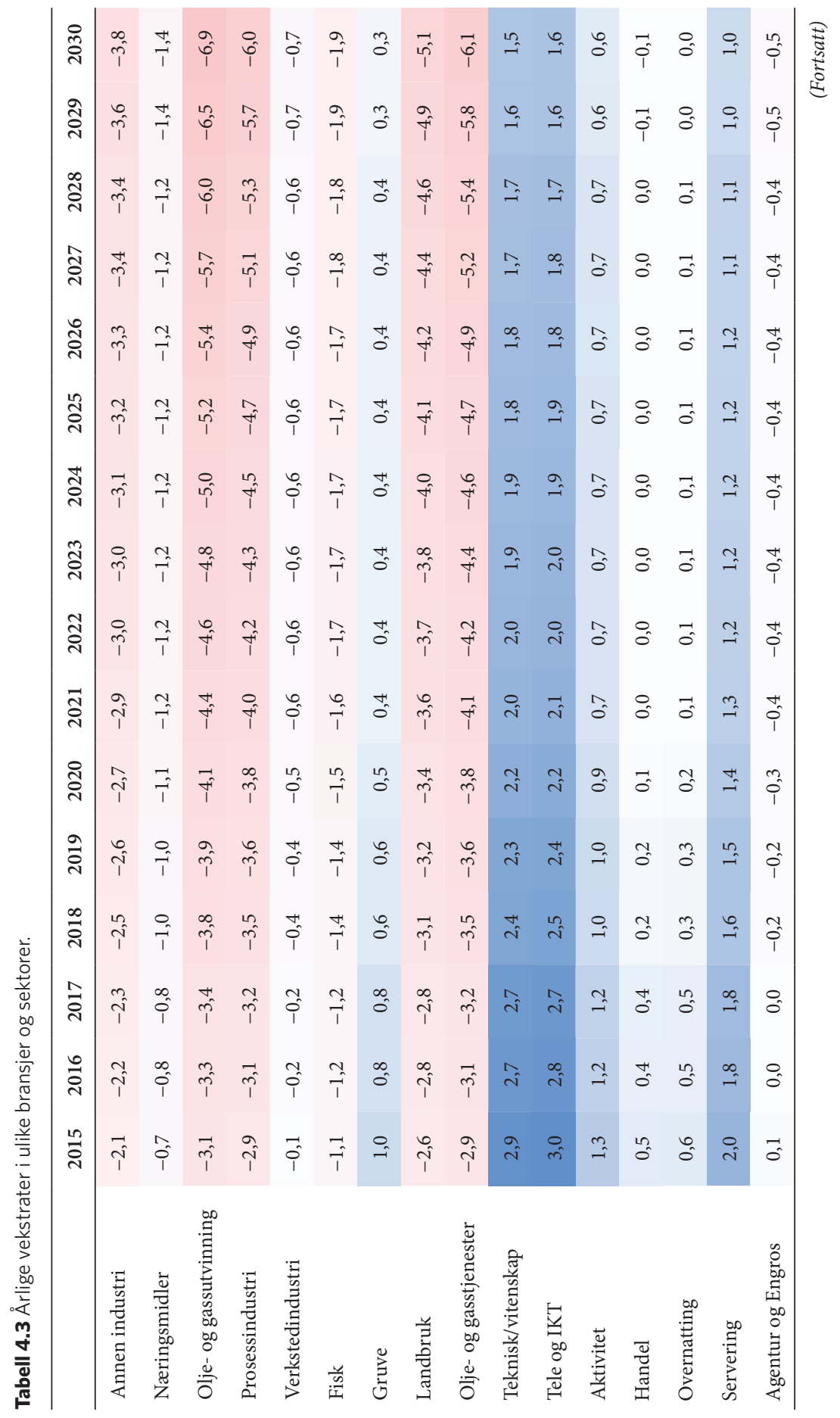




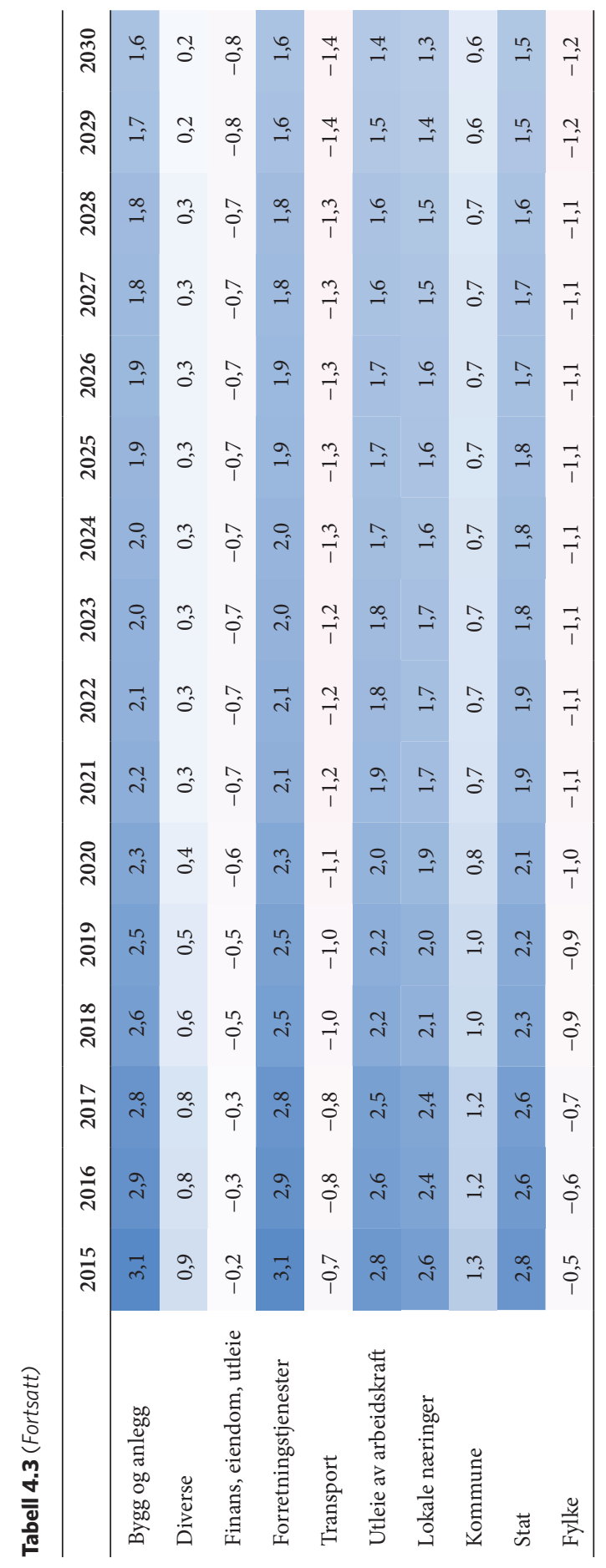


vi justert ned alle bransjenes vekst slik at samlet vekst blir lik den vi har forutsatt. For framtidig vekst har vi lagt inn en lineær vekst, for å unngå at noen bransjer «vokser til himmels».

I tabell 4.2 har vi vist årlige vekstrater for hele den framtidige perioden. Vekstratene er imidlertid høyest i begynnelsen av perioden og lavere etter hvert på grunn av at vi har lagt inn at den samlede veksten skal bli lavere.

I tabell 4.3 ser vi hvilke forutsetninger om vekst som er lagt inn i scenariomodellen.

Den framtidige utviklingen vil helt sikkert avvike vesentlig fra det vi har lagt inn her. Det er naturligvis ikke mulig å forutsi sikkert om hvilke bransjer som får vekst og hvilke bransjer som vil få nedgang. Spørsmålet er om de forutsetningene vi legger inn, vil være bedre enn om vi la inn at alle bransjer og sektorer fikk samme vekst. Det er det grunn til å tro at de er. Den strukturelle utviklingen har i mange år vært at primærnæringer og vareproduserende industri gradvis krymper i antall arbeidsplasser, mens tjenestesektoren øker. En del av drivkraften er teknologisk utvikling med automatisering og rasjonalisering i primær- og sekundærnæringene. Det er lite som tyder på at denne utviklingen vil stoppe opp med det første. Den strukturelle utviklingen vi har lagt inn, er i grove trekk en fortsettelse av denne langsiktige historiske trenden, med unntak av at oljerelaterte bransjer er forutsatt å gå fra sterk vekst til nedgang.

Hvis vi hadde laget en scenariomodell uten å spesifisere vekstrater i de enkelte bransjene, hadde det vært det samme som å forutsette at en region med en stor andel av arbeidsplassene i landbruk og tradisjonell industri har samme betingelser for vekst som en annen region med mesteparten av arbeidsplassene i tjenestesektoren og statlig virksomhet. En utvikling der alle bransjer og sektorer vokser med nøyaktig samme takt, er nok mer usannsynlig enn den utviklingen vi viser i tabellen over.

\subsection{Noen resultater av modellen}

Scenariomodellen ble opprinnelig utviklet for å vise hvor mye ekstra vekst en kommune, en region eller et fylke kunne oppnå gjennom å øke sin attraktivitet. Modellen gir også noen interessante utviklingstrekk når det gjelder framtidige vekstmønstre i Norge. Vi skal vise noen eksempler. 


\subsubsection{Hvor kommer arbeidsplassveksten?}

I tabell 4.4 har vi vist arbeidsplassveksten i fylkene de siste ti årene, og den beregnede veksten de neste ti.

Veksten i antall arbeidsplasser i Norge de neste ti årene er beregnet å bli 8,4 prosent. Det er så vidt over halvparten av veksten som har vært de siste ti. Noe av dette skyldes at veksten i folketallet i Norge er antatt å bli lavere, i henhold til SSBs middelframskrivinger, som vi bruker som utgangspunkt. Noe skyldes også at andelen av befolkningen som er i aldersgruppene med høyest sysselsettingsandel, går ned.

Tabell 4.4 Antall arbeidsplasser i 2004 og 2014 samt beregnet antall arbeidsplasser i 2024, og samlet vekst siste ti år og beregnet vekst neste ti år.

\begin{tabular}{|c|c|c|c|c|c|}
\hline & 2004 & 2014 & 2024 & Vekst siste ti år & Vekst neste ti år \\
\hline Østfold & 108755 & 119125 & 126148 & 9,5 & 5,9 \\
\hline Akershus & 216132 & 266227 & 296194 & 23,2 & 11,3 \\
\hline Oslo & 383290 & 457000 & 529883 & 19,2 & 15,9 \\
\hline Hedmark & 81867 & 87634 & 90961 & 7,0 & 3,8 \\
\hline Oppland & 83187 & 87873 & 91460 & 5,6 & 4,1 \\
\hline Buskerud & 109910 & 126647 & 136276 & 15,2 & 7,6 \\
\hline Vestfold & 95304 & 107228 & 114112 & 12,5 & 6,4 \\
\hline Telemark & 72344 & 76279 & 79558 & 5,4 & 4,3 \\
\hline Aust-Agder & 43145 & 48964 & 51955 & 13,5 & 6,1 \\
\hline Vest-Agder & 75650 & 89462 & 96469 & 18,3 & 7,8 \\
\hline Rogaland & 192822 & 248480 & 261156 & 28,9 & 5,1 \\
\hline Hordaland & 216518 & 261343 & 282768 & 20,7 & 8,2 \\
\hline Sogn og Fjordane & 51582 & 55005 & 56374 & 6,6 & 2,5 \\
\hline Møre og Romsdal & 114616 & 131844 & 136280 & 15,0 & 3,4 \\
\hline Sør-Trøndelag & 138387 & 163837 & 181024 & 18,4 & 10,5 \\
\hline Nord-Trøndelag & 56608 & 62844 & 65158 & 11,0 & 3,7 \\
\hline Nordland & 107948 & 117217 & 122343 & 8,6 & 4,4 \\
\hline Troms & 75617 & 83124 & 90171 & 9,9 & 8,5 \\
\hline Finnmark & 33962 & 37922 & 39612 & 11,7 & 4,5 \\
\hline Norge & 2257644 & 2628055 & 2847902 & 16,4 & 8,4 \\
\hline
\end{tabular}


Rogaland har hatt klart sterkest arbeidsplassvekst de siste ti årene, men er beregnet å få en lavere vekst enn landsgjennomsnittet de neste ti årene. Det er en følge av at vi har lagt inn nedgang i oljebasert næringsliv.

Oslo er beregnet å få den sterkeste veksten de neste ti årene, fulgt av Akershus og Sør-Trøndelag. Det er disse tre fylkene som har den mest gunstige bransjefordelingen i forhold til de forutsetningene vi har gjort. Disse tre fylkene har også de beste strukturelle betingelsene for å få innflytting, som igjen genererer vekst i befolkningsfølsomme bransjer og i kommunesektoren.

\subsubsection{Arbeidsplassvekst i regionene}

Vi kan også se på mønstrene i arbeidsplassutviklingen i regionene, som vist i kartene under.

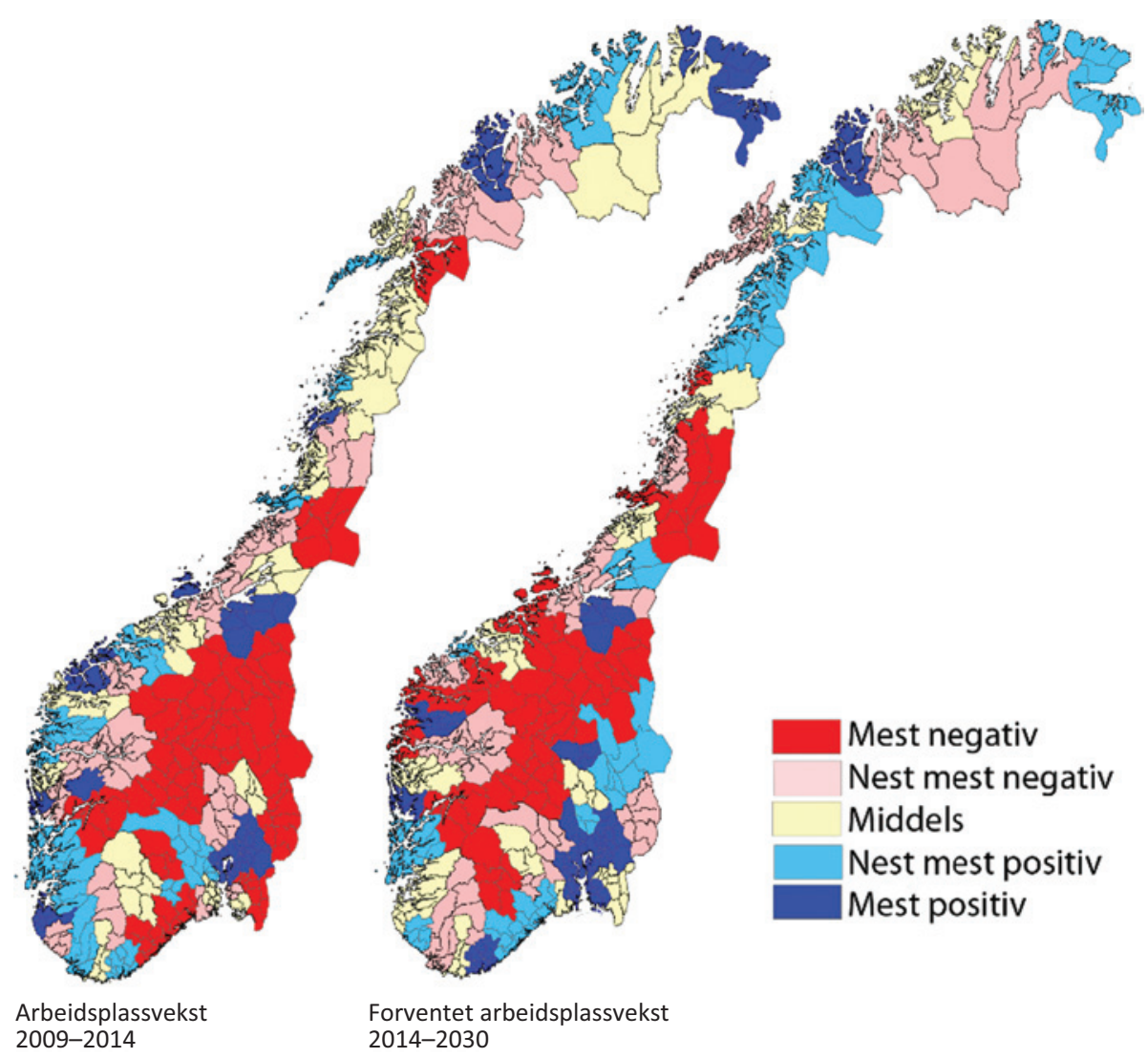

Figur 4.55 Variasjoner i arbeidsplassveksten mellom regionene i perioden 2009-2014 og forventede variasjoner fram til 2030. Regionene er gruppert etter kvantiler. 
Sentraliseringen i arbeidsplassveksten vil fortsette, ifølge modellen. De mest sentrale områdene antas fortsatt å dra fordel av de strukturelle flyttebetingelsene og vil dermed få stimulert arbeidsplassveksten gjennom at de får høyere befolkningsvekst. Samtidig vil også den strukturelle utviklingen være til gunst for de mest sentrale regionene, ettersom de har størst andel av arbeidsplassene i bransjer som forventes å vokse mest. Forskjellen er størst for Rogaland, fordi vi forventer nedgang i oljebasert næringsliv.

I kartet som viser den historiske utviklingen, til venstre, har vi noen regioner som har overrasket. Det gjelder Hitra/Frøya, Kystgruppen (Vikna, Nærøy og Leka), Øst-Finnmark, Voss og Sunnmøre. I kartet med forventet vekst er det naturligvis ingen overraskelser, fordi vi baserer beregningene på at regionene får en utvikling i tråd med de strukturelle forutsetningene. Det er det samme som at vi forutsetter at ingen av regionene er attraktive eller lite attraktive. Det vil naturligvis komme noen overraskelser også i framtiden, men vi har ingen metoder for å finne ut hvilke det er, på forhånd.

\subsubsection{Oljekrisens betydning for fylkene}

Med scenariomodellen kan vi også vise hvordan den nye strukturelle utviklingen påvirker arbeidsplassveksten i næringslivet i alle fylkene. Vi har da modellert inn effekten av nedgang i oljebransjene sammen med de rekursive effektene via flytting og befolkningsfølsomme bransjer.

De tre fylkene som blir mest positivt påvirket, er Oslo, Hedmark og Nordland. I disse tre fylkene vil veksten i antall arbeidsplasser i næringslivet bli 4,2 prosentpoeng høyere.

Det er bare to fylker som får lavere vekst: Rogaland og Hordaland. Rogaland blir langt mer påvirket enn noe annet fylke og får veksten redusert med hele 14,5 prosentpoeng. Rogaland får imidlertid bedre arbeidsplassvekst enn mange fylker selv med nedgang i oljebransjene.

Det er naturligvis stor usikkerhet i hva som virkelig blir resultatet av oljekrisen, hvor lenge den varer, og om andre bransjer får økt vekst. Det vil naturligvis også ha betydning hvordan de enkelte områdene reagerer på oljekrisen, og i hvilken grad de makter å omstille seg.

Analysene gir imidlertid en god pekepinn på hvem som blir mest og minst berørt, og viser hvordan den nye strukturelle utviklingen påvirker vekstutsiktene i fylkene relativt til hverandre. 
Tabell 4.5 Prosentvis vekst i antall arbeidsplasser fra 2014 til 2030 for to alternativer. Trend er en framskriving av bransjenes vekst de ti siste årene. Oljejustert er forventet vekst når olje- og gassrelaterte næringer får nedgang og andre næringer får økt vekst, slik at samlet arbeidsplassvekst blir lik i hele landet.

\begin{tabular}{lccc}
\hline Sted & Vekst trend & Vekst oljejustert & Differanse \\
\hline Oslo & 16,7 & 20,9 & 4,2 \\
Hedmark & $-0,2$ & 4,0 & 4,2 \\
Nordland & 0,7 & 5,0 & 4,2 \\
Østfold & 2,8 & 6,8 & 4,0 \\
Oppland & 0,4 & 4,4 & 4,0 \\
Vestfold & 3,7 & 7,6 & 3,9 \\
Telemark & 1,3 & 4,9 & 3,6 \\
Buskerud & 5,9 & 9,4 & 3,5 \\
Vest-Agder & 6,0 & 9,6 & 3,5 \\
Troms & 7,0 & 10,5 & 3,5 \\
Sogn og Fjordane & $-0,7$ & 2,7 & 3,4 \\
Sør-Trøndelag & 9,9 & 13,2 & 3,4 \\
Akershus & 13,1 & 15,1 & 2,1 \\
Nord-Trøndelag & 2,2 & 4,2 & 2,0 \\
Finnmark & 2,8 & 4,9 & 2,0 \\
Aust-Agder & 11,5 & 7,3 & 1,9 \\
Møre og Romsdal & 19,9 & 3,2 & 1,1 \\
Hordaland & 2,1 & 10,1 & $-1,5$ \\
Rogaland & 5,4 & $-14,5$ \\
\hline
\end{tabular}

Vi kan også se på hvordan forventet arbeidsplassvekst blir, med de to alternative bransjeframskrivingene på regionnivå.

Kartet lengst til høyre i figur 4.56 viser differansen mellom de to alternative bransjeframskrivingene og viser hvilke regioner som kommer bedre og dårligere ut etter oljekrisen. Nesten alle regionene på Vestlandet kommer ut svakere. På Østlandet blir Kongsbergregionen og Akershus Vest negativt påvirket, mens de fleste regionene i landsdelen kommer bedre ut. Mange regioner i Nord-Norge får også en bedre utvikling med den nye strukturutviklingen, med unntak av Harstadregionen og Vest-Finnmark. 


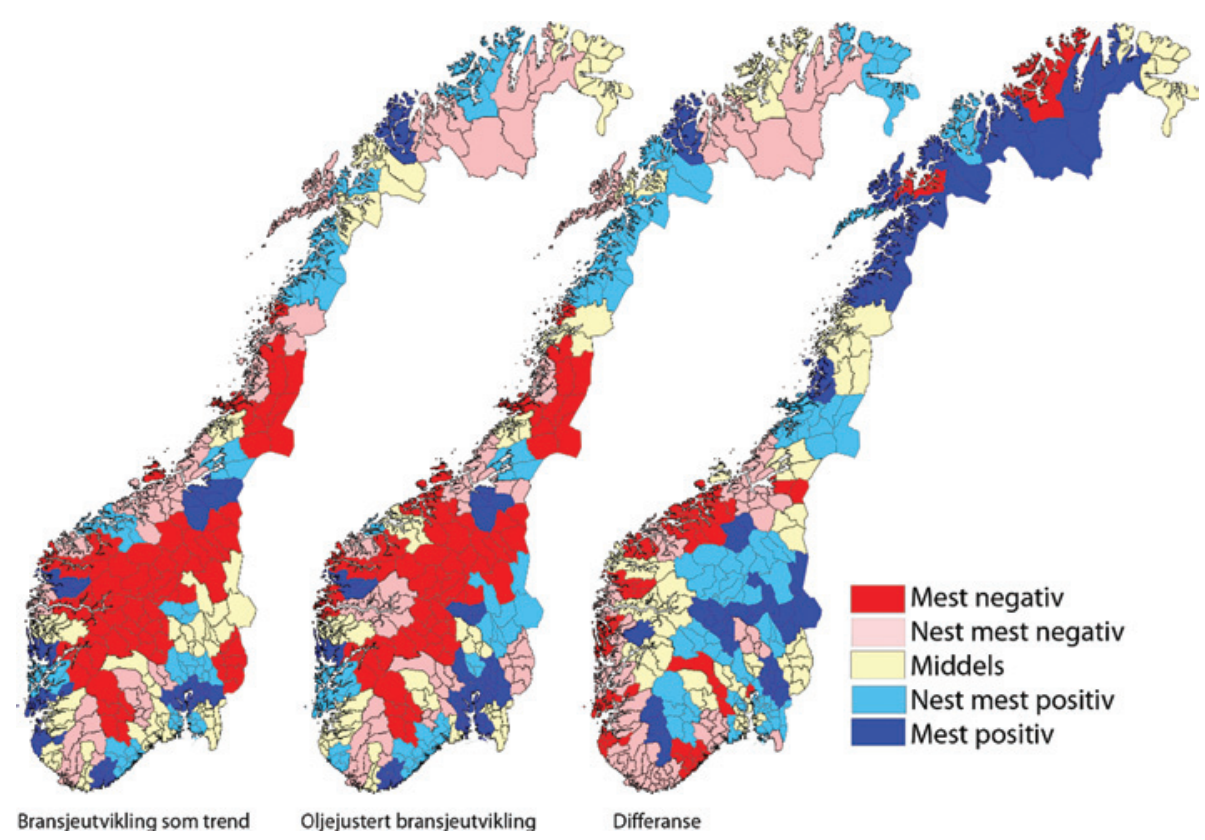

Figur 4.56 Forventet arbeidsplassvekst i regionene. Til venstre: med trendframskriving av den strukturelle utviklingen (fortsatt vekst i oljerelaterte bransjer). I midten: med strukturell utvikling med nedgang i oljerelaterte bransjer. Til høyre: differansen mellom de to alternativene.

Scenariomodellen kan brukes til å simulere hvordan den regionale utviklingen blir påvirket av strukturendringer i næringslivet. Her har vi vist hvordan oljekrisen sannsynligvis vil slå ut. Det er naturligvis også mulig å vise andre scenarioer for strukturendringer.

\subsubsection{Scenarioer med høy og lav attraktivitet}

Hensikten med å lage scenariomodellen var å vise hvordan ulike nivåer for attraktivitet vil slå ut for framtidig utvikling i folketall og antall arbeidsplasser. Siden vi har verdiene for attraktivitet for kommuner, regioner og fylker i perioden 2000 til 2015, har vi et grunnlag for å beregne hva som er øvre og nedre grense for hvor attraktivt et sted kan bli innenfor en realistisk grad av sannsynlighet. Vi betegner området innenfor sannsynlige verdier av attraktivitet for mulighetsrommet for et steds attraktivitet. Vi kan da beregne den mulige utviklingen for ulike steder. For et gitt sett av strukturelle betingelser vil mulighetsrommet for attraktivitet også definere øvre og nedre grenser for vekst i befolkning og antall arbeidsplasser på et sted. 
De fleste stedene, enten det er kommuner, regioner eller fylker, har svært ofte mål om å være attraktive steder som bosted og for næringslivet. De ønsker dermed å gjennomføre en politikk med ulike tiltak og virkemidler for å stimulere til økt vekst. I mange tilfeller er mål om befolkningsveksten også tallfestet. Noen steder tallfester også mål om arbeidsplassutviklingen på stedet. For slike steder er et scenario med høy attraktivitet interessant, fordi det kan vise hva som er høyeste sannsynlige vekst.

Vi kan illustrere verdiene for bosteds- og næringsattraktivitet med å sette verdiene i et diagram med historiske attraktivitetsverdier for de 84 regionene. Vi setter da verdiene slik at de blir forholdsvis høye, tilsvarende regionen som var rangert som nummer 15 av de 84 regionene. Høyvekstscenarioet vil da ha forholdsvis høye verdier for både bosteds- og næringsattraktivitet, mens lavvekstscenarioet vil ha lave verdier for begge disse attraktivitetsdimensjonene.

Det vil ikke bli spesielt vanskelig å bli attraktiv tilsvarende region nummer 15 for en av attraktivitetsdimensjonene. Sannsynligheten er omtrent 15/84, eller i underkant av 18 prosent. Men siden attraktiviteten for bosted og næring ikke er korrelert, vil sannsynligheten for å oppnå denne attraktivitetsverdien for to dimensjoner samtidig være langt mindre, i overkant av 3 prosent. Det betyr at det vil være omtrent to til tre regioner som vil få en vekst over høyvekstscenarioet, og to til tre som vil få en vekst lavere enn lavvekstscenarioet. Vi kan se av figur 4.57 at det var fire regioner som hadde sterkere vekst enn høyvekstscenarioet i de siste 15 årene. Regionen som er helt oppe til høyre, er Hitra/ Frøya, som hadde høyeste verdi for både nærings- og bostedsattraktivitet i denne perioden. Det var ingen regioner som hadde lavere vekst enn lavvekstscenarioet. En kan spekulere på om det betyr at det er mekanismer som hindrer regioner i å få svært lave verdier for nærings- og bostedsattraktivitet samtidig. Så langt har vi ikke grunnlag for å si noe om det. Det kan være helt tilfeldig at ingen regioner hadde en kombinasjon av nærings- og bostedsattraktivitet som ga lavere vekst enn lavvekstscenarioet i denne perioden.

Normalscenarioet forutsetter at regionen har attraktivitetsverdier lik null. Det betyr at utviklingen går nøyaktig som forventet ut fra de strukturelle betingelsene.

Vi har også laget et fjerde scenario. Det er basert på at regionen beholder sine attraktivitetsverdier.

I figur 4.57 illustrerte vi verdiene i scenarioene med å vise attraktivitetsverdiene til regionene. Scenarioene for kommuner vil være basert på 


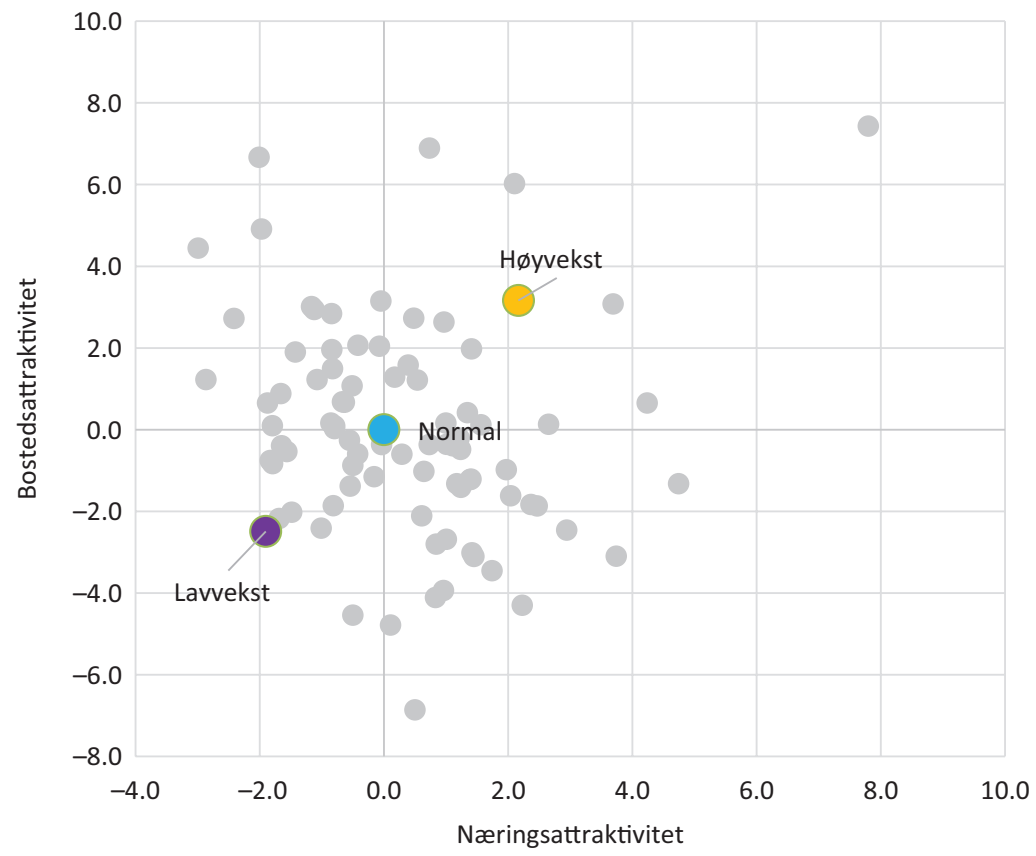

Figur 4.57 Attraktivitetsverdier for regioner i perioden 2000-2015, og attraktivitetsverdiene til høyvekst-, normal- og lavvekstscenarioet.

attraktivitetsverdier for kommuner i samme periode. Attraktivitetsverdiene for kommuner varierer mer enn tilsvarende for regioner, og dermed blir også attraktivitetsverdiene høyere i høyvekstscenarioet og lavere i lavvekstscenarioet.

Tilsvarende blir attraktivitetsverdiene for scenarioer for fylker lavere enn for regioner, fordi attraktivitetsverdiene for fylker har variert mindre enn attraktivitetsverdiene til regionene.

I tabell 4.6 viser vi de attraktivitetsverdiene som brukes i scenarioene. Attraktivitetsverdiene er basert på spredningen for perioden 2000-2015. For kommuner er verdien satt lik kommunen som er rangert som nummer 50 for høyvekstscenarioet og nummer 50 fra bunn for lavvekstscenarioet. For regioner er verdien satt lik region nummer 15 fra topp og bunn. For fylker er verdiene tredje fylke fra topp og bunn.

Verdiene for bostedsattraktivitet er ekstra nettoinnflytting per år. For næringsattraktivitet forstås verdien som ekstra prosentvis årlig vekst $i$ antall arbeidsplasser i næringslivet. 
Tabell 4.6 Attraktivitetsverdier i høy- og lavvekstscenarioene for kommuner, regioner og fylker.

\begin{tabular}{lccc}
\hline & Kommune & Region & Fylke \\
\hline Bostedsattraktivitet høy & 0,47 & 0,26 & 0,17 \\
Næringsattraktivitet høy & 1,81 & 0,86 & 0,38 \\
Bostedsattraktivitet lav & $-0,37$ & $-0,21$ & $-0,12$ \\
Næringsattraktivitet lav & $-1,30$ & $-0,83$ & $-0,47$ \\
\hline
\end{tabular}

Høyvekstscenarioet for kommuner er da basert på at kommunen får en ekstra nettoinnflytting tilsvarende 0,47 prosent av folketallet hvert år og en ekstra vekst på 1,81 prosent $\mathrm{i}$ antall arbeidsplasser hvert år.

Det er naturlig at attraktivitetsverdiene, og de tilsvarende mulighetene, er større for kommuner enn for regioner og fylker. Dess mindre geografisk nivå, dess større avvik fra normal utvikling i høy- og lavvekstscenarioene. Kanskje burde vi også tatt høyde for at små kommuner burde ha et større spenn i mulighetsrommet enn store kommuner. Vi finner imidlertid flere store (folkerike) kommuner med ganske ekstreme attraktivitetsverdier i perioden fra 2000 til 2015.

\subsubsection{Frøya}

Scenariomodellen er laget for å vise hva som er sannsynlige scenarioer for arbeidsplass- og befolkningsvekst for kommuner, regioner eller fylker. Hensikten med den er å få et bilde på hvor mye et steds attraktivitet betyr for framtidig utvikling. En kommune eller region vil dermed kunne fă tall for hvor sterk vekst som det er mulig å skape gjennom å bli attraktiv. Dette er et høyst relevant spørsmål i kommunal planlegging. Mange kommuner, regioner og fylker har eksplisitte mål for befolkningsvekst i sine samfunnsplaner. Disse målene er ofte ambisiøse. Stedene har naturligvis ambisjoner om å skape attraktivitet for både næringsliv og befolkning, og legger seg i de fleste tilfellene over SSBs prognoser når de fastsetter sine mål.

Filosofien som ligger bak attraktivitetsmodellen, er at steder kan påvirke sin egen vekst, selv om betingelsene for vekst varierer fra sted til sted og over tid. I tråd med dette er scenariomodellen laget for å vise ulike scenarioer, spesielt hvordan et steds attraktivitet varierer over tid. 
Det er fire scenarioer som peker seg ut som relevante i denne sammenhengen. De to første er disse:

Normalscenarioet. Dette er basert på at stedet har en utvikling nøyaktig i tråd med sine strukturelle betingelser. Stedet er verken attraktivt for bosetting og næringsliv eller lite attraktivt.

Scenario med historisk attraktivitet. Dette forutsetter at stedet fortsetter å ha samme attraktivitet for bosetting og næringsliv som det har hatt i gjennomsnitt de ti siste årene.

Vi kan se litt på hvordan disse to scenarioene kan gi svært ulik vekst. For å illustrere dette tar vi for oss en kommune som har vært spesielt attraktiv de siste årene: Frøya.

I figur 4.58 ser vi at normalscenarioet viser en befolkningsvekst i Frøya fra 4799 innbyggere i 2016 (1. jan) til 5013 innbyggere i 2030. Det er utviklingen som er forventet dersom Frøya har en helt normal og gjennomsnittlig attraktivitet for næringsliv og bosetting. Scenarioet med historisk attraktivitet er basert på at Frøyas attraktivitetsverdier for de ti siste årene er de samme i de kommende årene. Det gir en langt høyere vekst: Folketallet vil da bli 6406 i 2030.

Både normalscenarioet og scenarioet med historisk attraktivitet kan være sannsynlige prognoser for utviklingen. Hvilket av disse som er mest

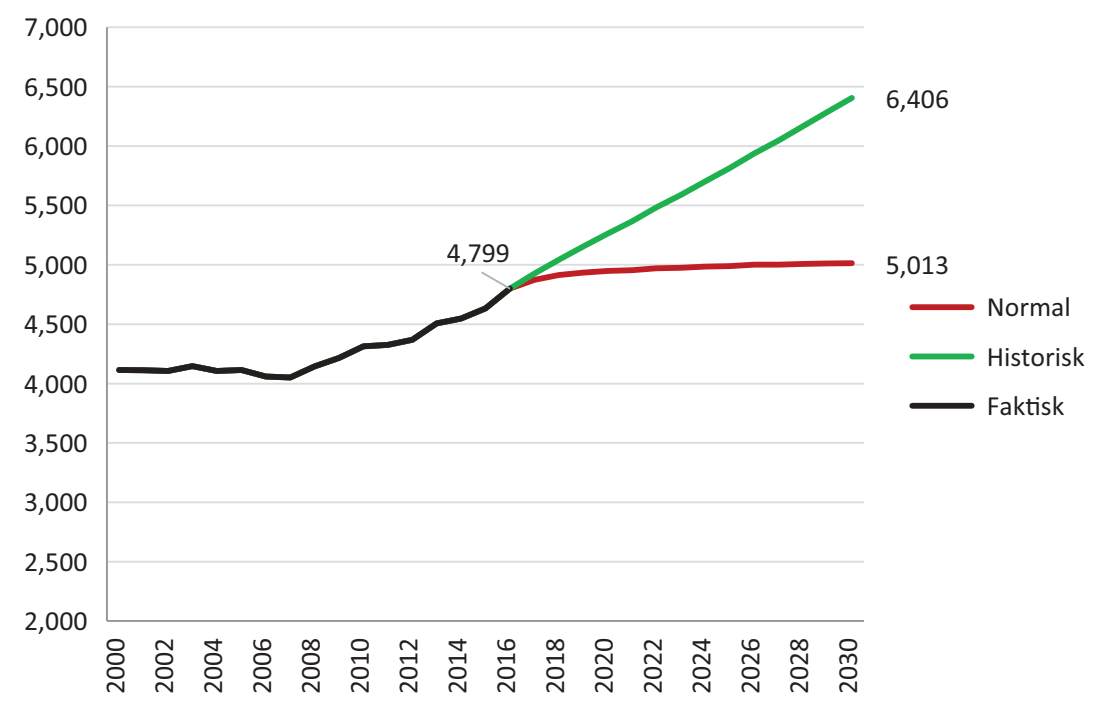

Figur 4.58 Scenarioer for befolkningsvekst i Frøya. 
sannsynlig, er ikke umiddelbart enkelt å svare på. Dersom en kommune har hatt høy attraktivitet de siste årene, vil scenarioet med historisk attraktivitet vise en sterkere befolkningsvekst enn normalscenarioet. I et slikt tilfelle må vi vurdere om det er grunn til å anta at den høye attraktiviteten i kommunen vil fortsette, eller om den høye attraktiviteten skyldes spesielle og mer tilfeldige omstendigheter. Dersom den høye attraktiviteten i kommunen skyldes at kommunen har en spesielt god lokal politikk som skaper høy bostedsattraktivitet og gir sterke stimulanser til næringslivet, vil den høye attraktiviteten kunne være et resultat av dette. Da vil en kanskje forvente at dette fortsetter, og at den høye attraktiviteten opprettholdes. I andre tilfeller kan det være at den høye attraktiviteten skyldes mer tilfeldige forhold, som at en ekstern investor etablerte en ny stor bedrift i kommunen, eller at en lokal hjørnesteinsbedrift hadde spesielt sterk vekst i perioden. Slik «flaks» vil en kanskje ikke kunne regne med vil gjenta seg. I så fall vil kanskje normalscenarioet være det mest sannsynlige. I praksis er det slik at det er en viss positiv korrelasjon mellom attraktivitet i ulike perioder. Sammenhengen blir svakere dess lengre tiden går. Dermed vil kanskje det mest sannsynlige være at utviklingen i kommunen kommer til å ligge et sted mellom normalscenarioet og scenarioet med historisk attraktivitet.

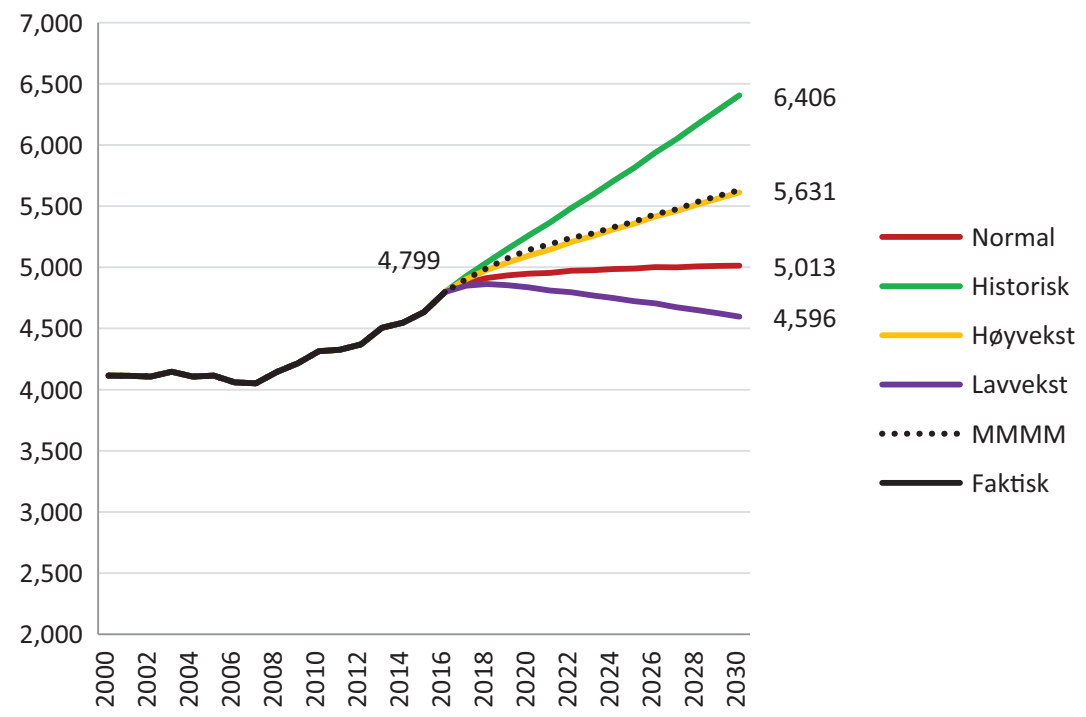

Figur 4.59 Alle de fire scenarioene for folketallsutvikling i Frøya, samt MMMM som er SSBs middelframskriving. 
Høyvekstscenarioet er basert på at stedet har en jevn og høy attraktivitet for både bosetting og næringsliv i framtiden. Analysene som er gjort for perioden 2000-2015, viser hva som har vært variasjonen i attraktivitet i denne perioden. I de eksemplene vi skal vise, har vi lagt nivået på bostedsattraktivitet på samme nivå som gjennomsnittet til den kommunen som er rangert som nummer 50 av 428 kommuner de ti siste årene. Nivået for næringsattraktivitet i lavvekstscenarioet er satt på tilsvarende måte.

Høyvekstscenarioet for Frøya endre opp i et folketall på 5631 i 2030, mens lavvekstscenarioet viser en nedgang til 4 596. Ettersom Frøya har vært en av de mest attraktive kommunene, viser scenarioet med historisk attraktivitet en langt sterkere vekst enn høyvekstscenarioet. Ifølge scenariomodellen er nedgangen i lavvekstscenarioet omtrent like sannsynlig som veksten i høyvekstscenarioet.

\subsubsection{Kalibrering av mål i samfunnsplaner}

Alle kommuner skal ha sin kommuneplan. Kommuneplanen har normalt en samfunnsdel og en arealdel. I kommunenes samfunnsplaner er det ofte definert mål for vekst og utvikling, og en del kommuner har også tallfestet mål for befolkningsvekst. Scenariomodellen kan være svært nyttig for å kunne kalibrere målene i slike samfunnsplaner, slik at en unngår å sette mål som er urealistiske. Vi kan ta et eksempel fra Kongsberg. I samfunnsplanen kan vi lese:

Kongsberg med 40 ooo innbyggere er en ambisjon som skal vare førende for samfunnsutviklingen og ressursbruken $i$ kommunen. $2 \%$ årlig vekst $i$ befolkningen legges til grunn for dimensjonering av infrastruktur i plamperioden.

Hvor realistisk er det å oppnå to prosent befolkningsvekst i Kongsberg? For å svare på dette kan vi sammenlikne et scenario med to prosent befolkningsvekst med de scenarioene som vi får ut av attraktivitetsmodellen:

Scenarioene viser at Kongsberg med en helt normal utvikling vil få en vekst fra 27000 til i underkant av 28 ooo innbyggere i 2030. Kongsberg har vært en kommune med høy attraktivitet, både for næringsliv og for bosetting de siste årene. Dersom de greier å opprettholde denne høye attraktiviteten, vil befolkningsveksten bli høyere. Folketallet vil da ende opp i over 30 ooo i 2030. SSBs siste middelframskriving gir omtrent samme vekst. Høyvekstscenarioet baserer seg på at Kongsberg skal ha en jevn og sterk attraktivitet i hele perioden 


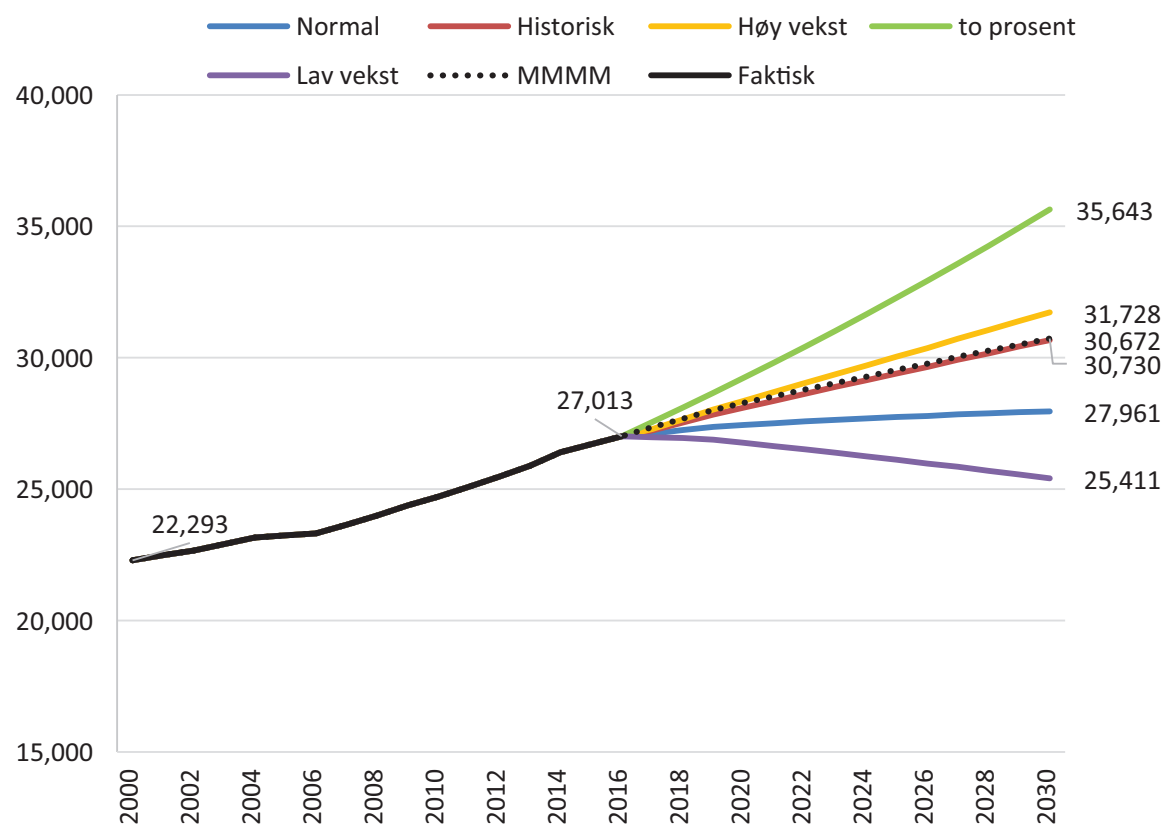

Figur 4.60 Scenarioer for befolkningsutvikling i Kongsberg samt MMMM som er SSBs middelframskriving.

fram til 2030. Da vil folketallet i Kongsberg kunne nærme seg 32 0oo. Det regner vi som det høyeste realistiske mål for befolkningsvekst. En vekst på to prosent årlig er imidlertid langt over dette. For at Kongsberg skal oppnå denne veksten, må de bli mer attraktive enn noen norsk kommune har vært i perioden fra 2000 til 2015. Vi snakker da om nivå på attraktivitet som vi ikke kjenner noen eksempler på i empirien. Konklusjonen er at Kongsbergs mål ikke er oppnåelige. Det er ikke spesielt uvanlig at kommunenes samfunnsplaner har konkrete mål om vekst som er urealistiske etter våre scenarioer. Vi har sett mange eksempler på det samme i andre kommuner. Det er dermed ikke meningen å henge ut Kongsberg i dette tilfellet, men å gi et konkret eksempel på, etter vår oppfatning, overambisiøse mål i kommunenes samfunnsplaner.

Gjør det noe om målene er overambisiøse (eller «hårete», som er et ord som ofte brukes i denne sammenhengen)? Etter vår mening er svaret ja. I Kongsbergs tilfelle vil de oppdage at veksten blir langt svakere enn målene de har satt seg. Hvis Kongsberg hadde endte opp med et folketall på 32000 i 2030, som er tallet fra høyvekstscenarioet, ville det vist at kommunen hadde vært svært attraktiv i perioden. Men ettersom dette hadde vært langt under målene, ville kommunen ha vært nødt til å spørre seg hva de hadde gjort feil, siden den 
ønskede veksten var langt unna målsettingene. Det riktige spørsmålet ville imidlertid ha vært hva kommunen hadde gjort riktig, siden Kongsberg hadde vært en av de mest attraktive kommunene i landet.

\subsubsection{Attraktivitetsmodellen og SSBs middelframskriving}

Når det gjelder den samlede befolkningsutviklingen i Norge, har attraktivitetsmodellen lagt til grunn at utviklingen skal bli som SSBs middelframskriving (forkortet $4 \mathrm{M}$ ). For å bestemme framtidig flytting har imidlertid attraktivitetsmodellen en annen logikk enn hva SSBs framskrivinger har.

En viktig forskjell er at SSB beregner innenlands flytting og ut- og innvandring hver for seg. Det er da ingen relasjon mellom et steds nettoinnvandring og et steds netto innenlandske nettoflytting. I attraktivitetsmodellen er steders innenlandske nettoflytting og nettoinnvandring behandlet samlet, som nettoflytting inkludert innvandring. Når Norges nettoinnvandring synker, vil SSBs modell gi som resultat at et sted som har hatt høy innvandring, får sterkest reduksjon i nettoinnvandringen, men uten at den innenlandske nettoflyttingen til stedet påvirkes. Dette påvirker blant annet befolkningsframskrivingen for Oslo. Oslo har ikke hatt nevneverdig netto innenlands nettoflytting de siste

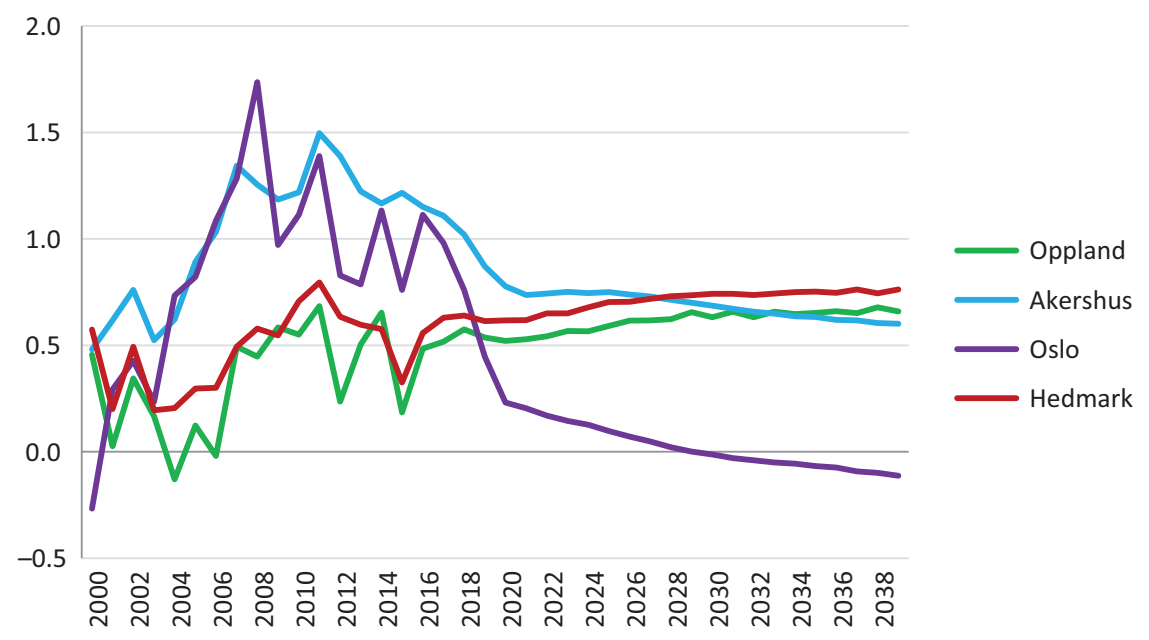

Figur 4.61 Nettoflytting fram til 2015 som prosent av folketallet, og beregnet nettoflytting i SSBs framskrivinger. 
årene, men har hatt ganske høy innvandring. SSBs metode gir som resultat at Oslo vil få lavere innvandring og høyere utvandring (på grunn av høy andel innvandrere i befolkningen). Siden Oslo ikke har hatt netto innenlands innflytting fra før, gir SSBs framskrivingsmetode at Oslo heller ikke får nettoinnflytting i framtiden.

I attraktivitetsmodellen antas steder å få høyere netto innflytting (inkludert innvandring) dersom de strukturelle betingelsene er positive. Oslo har strukturelle fordeler som kan gi høyere nettoinnflytting, fordi det er høy befolkningstetthet, et stort arbeidsmarked utenfor og fordi en høy andel av arbeidsplassene i Oslo er i bransjer og sektorer som er forventet å få vekst i framtiden. Dersom nettoinnvandringen til Norge synker, vil det bli høyere netto innflytting innenlands til Oslo i attraktivitetsmodellen.

For å vise forskjellene i befolkningsframskrivingene i SSBs framskrivinger og attraktivitetsmodellen, kan vi ta utgangspunkt i fire fylker hvor forskjellene er mest karakteristiske: Oslo, Akershus, Hedmark og Oppland.

Vi skal først vise hvordan SSBs framskrivinger slår ut. Fra 2016 har vi beregnet den relative nettoflyttingen som ligger implisitt i SSBs framskrivinger. Vi har da brukt befolkningsveksten i det enkelte år som framskrevet i $4 \mathrm{M}$

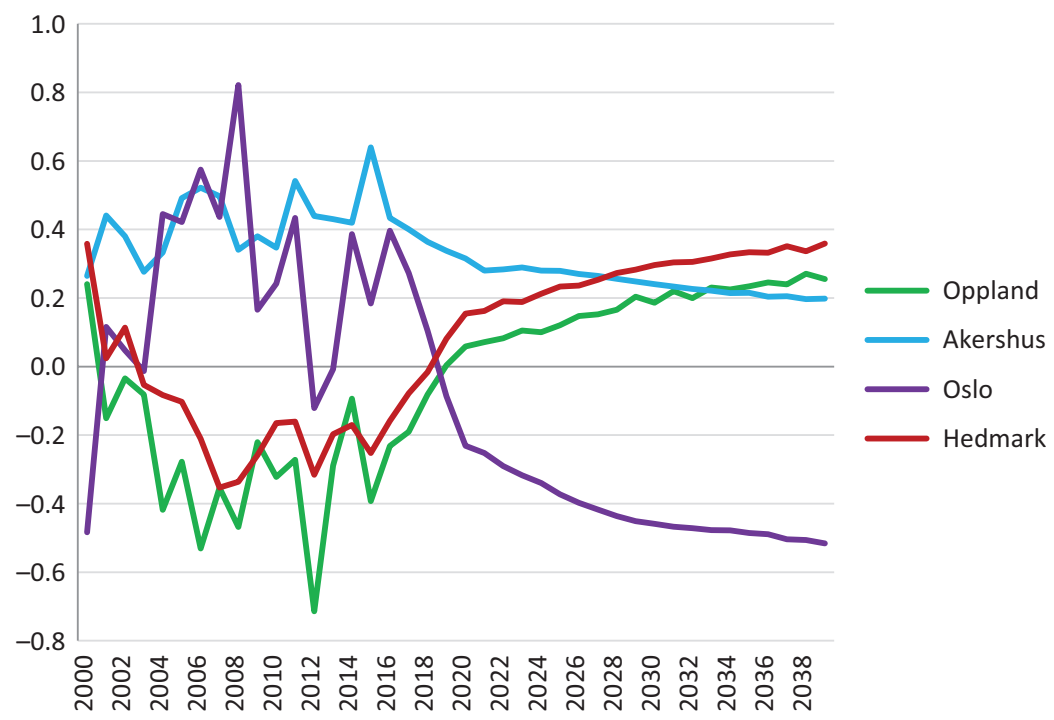

Figur 4.62 Relativ nettoflytting fram til 2015 som prosent av folketallet, og beregnet relativ nettoflytting i SSBs framskrivinger. 


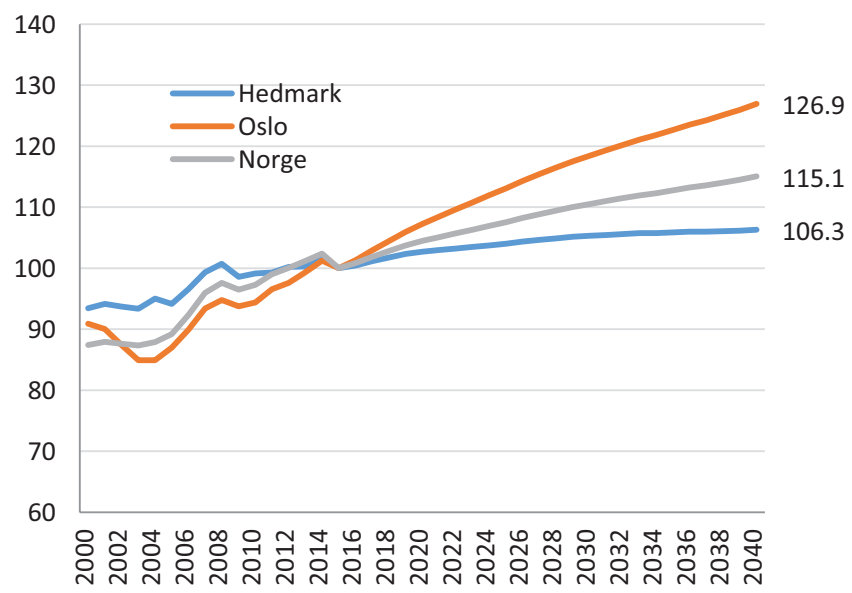

Figur 4.63 Scenarioer for arbeidsplassvekst i Oslo, Hedmark og Norge, indeksert slik at nivået i $2015=100$.

fratrukket differansen mellom fødte og døde fra 4M. Da får vi fram hvor stor nettoflytting som skal til for å nå befolkningsveksten i 4M.

Hvis SSBs middelframskriving skal slå til, vil både Hedmark og Oppland få høyere nettoflytting enn Oslo allerede i 2019. I 2027 skal Hedmark også få høyere nettoflytting enn Akershus. Oslo vil, ifølge beregningene i $4 \mathrm{M}$, få netto utflytting (inkludert innvandring) fra 2028. Det betyr ikke at folketallet i Oslo vil synke. Oslo er beregnet å ha ganske stor positiv fødselsbalanse som vil gi befolkningsvekst.

Den relative nettoflyttingen som ligger implisitt i $4 \mathrm{M}$ er vist i figur 4.62. Vår scenariomodell genererer først forventet arbeidsplassvekst, og dernest forventet relativ nettoflytting. Så legger vi til bidrag fra innvandring og fødselsbalanse som vi hentet fra $4 \mathrm{M}$. Forskjellen i befolkningsvekst mellom vår scenariomodell og $4 \mathrm{M}$ er at vi har en annen modell for flyttingen.

Figur 4.63 viser hvordan resultatene fra scenarioene for Hedmark og Oslo. Forventet arbeidsplassvekst i Oslo er en del sterkere enn landsgjennomsnittet fordi Oslo har en stor andel av arbeidsplassene sine i bransjer som er forventet å vokse. Samtidig er befolkningen i Oslo forventet å vokse raskere enn landsgjennomsnittet, noe som stimulerer veksten i bransjer som har et lokalt marked. I Hedmark er arbeidsplassveksten forventet å være lavere enn landsgjennomsnittet fordi bransjesammensetningen er lite gunstig, og fordi Hedmark er forventet å få lavere befolkningsvekst. 


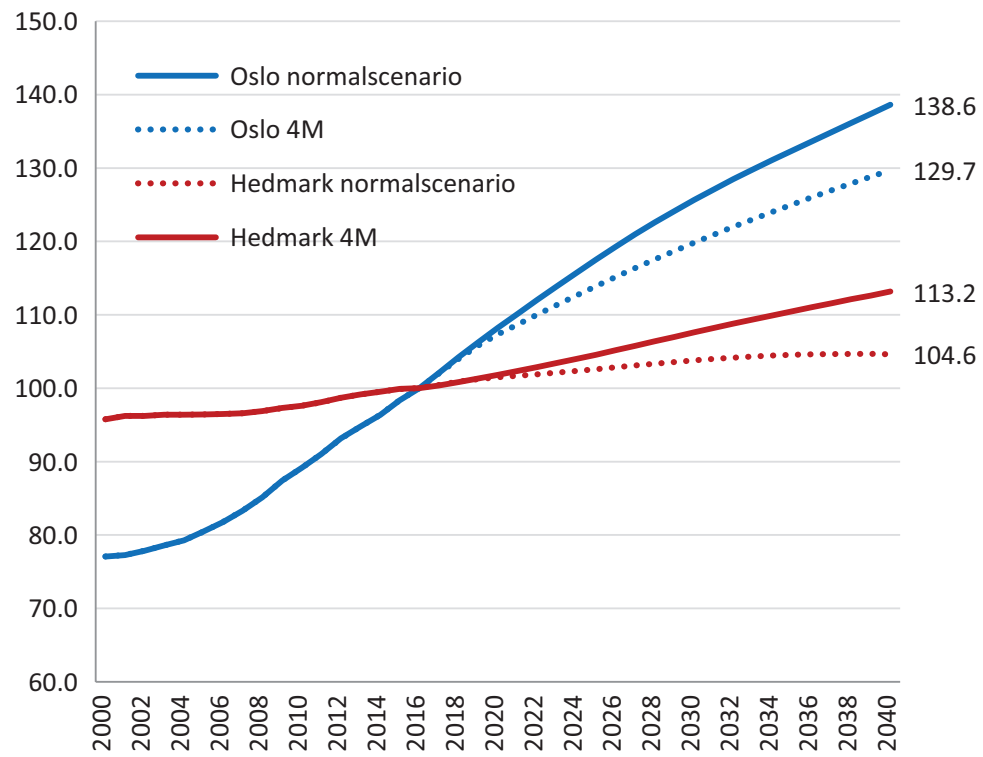

Figur 4.64 Normalscenarioer og SSBs middelprognose for befolkning, for Oslo og Hedmark. Indeksert slik at nivået i $2016=100$.

Den sterke arbeidsplassveksten i Oslo er forventet å føre til at nettoflyttingen til Oslo blir høyere. Tilsvarende vil nettoflyttingen til Hedmark bli lavere på grunn av lavere arbeidsplassvekst.

Oslo vil også få høyere nettoflytting fordi det er et område med høy befolkningstetthet og midtpunktet i landets største funksjonelle arbeidsmarked. (Det vil si stor befolkning og høy arbeidsmarkedsintegrasjon.)

Forskjellene i befolkningsutviklingen med vår scenariomodell og SSBs framskrivinger blir ganske store for disse to fylkene. Disse forskjellene er ikke bare av akademisk interesse. Behovet for boligbygging i Oslo er et aktuelt tema i disse dager. Forventet tilflytting og befolkningsvekst i Oslo er det viktigste grunnlaget for å fastsette behovet for boligbygging. Da blir SSBs framskrivinger ofte brukt som underlag. Etter vår modell vil befolkningsveksten i Oslo kunne bli langt høyere enn i SSBs framskrivinger. Da blir også behovet for boligbygging større.

I Hedmark har fylkeskommunen i sin regionale planstrategi (2012-2015) en erklæring om å vokse til 220000 innbyggere. Vi kan sitere fra plandokumentet: 
Erkloeringens hovedlinje er å føre en politikk som skal sikre en befolkningsutvikling som fører til at vi har 220 ooo innbyggere i Hedmark i løpet av kort tid. Det er en ambisjon som er avgjørende for å sikre et borekraftig Hedmark på lang sikt. All praktisk politikk fra Senterpartiet og Arbeiderpartiet vil rettes inn mot målet om 220 ooo innbyggere.

I SSBs middelsframskriving skal Hedmark nå dette innbyggertallet i 2039. Hedmark fylkeskommune tenker seg i sin planstrategi at de kan tilskynde denne befolkningsveksten gjennom å føre en politikk som gir høyere attraktivitet for næringsliv og bosetting.

I scenarioene i figur 4.65 har vi lagt inn et høyvekstscenario som viser hva vi regner som høyeste sannsynlige vekst. Dette scenarioet henter attraktivitetsverdier fra de historiske analysene og setter verdien til det tredje beste fylket for henholdsvis nærings- og bostedsattraktivitet. Å oppnå attraktivitet som det tredje beste fylket for en attraktivitetsdimensjon er kanskje ikke urealistisk vanskelig, men å oppnå denne attraktivitetsverdien for to attraktivitetsdimensjoner (som er uavhengig av hverandre) regner vi som den mest ambisiøse målsettingen som er innenfor en viss realisme. Høyvekstscenarioet ender opp i et folketall i Hedmark på 217073 i 2040. Etter våre beregninger er derfor målet om å komme opp i et folketall i Hedmark på 220000 «i løpet av kort tid» helt urealistisk. I hvert fall dersom «kort tid» er mindre enn 20 år. Det er ikke

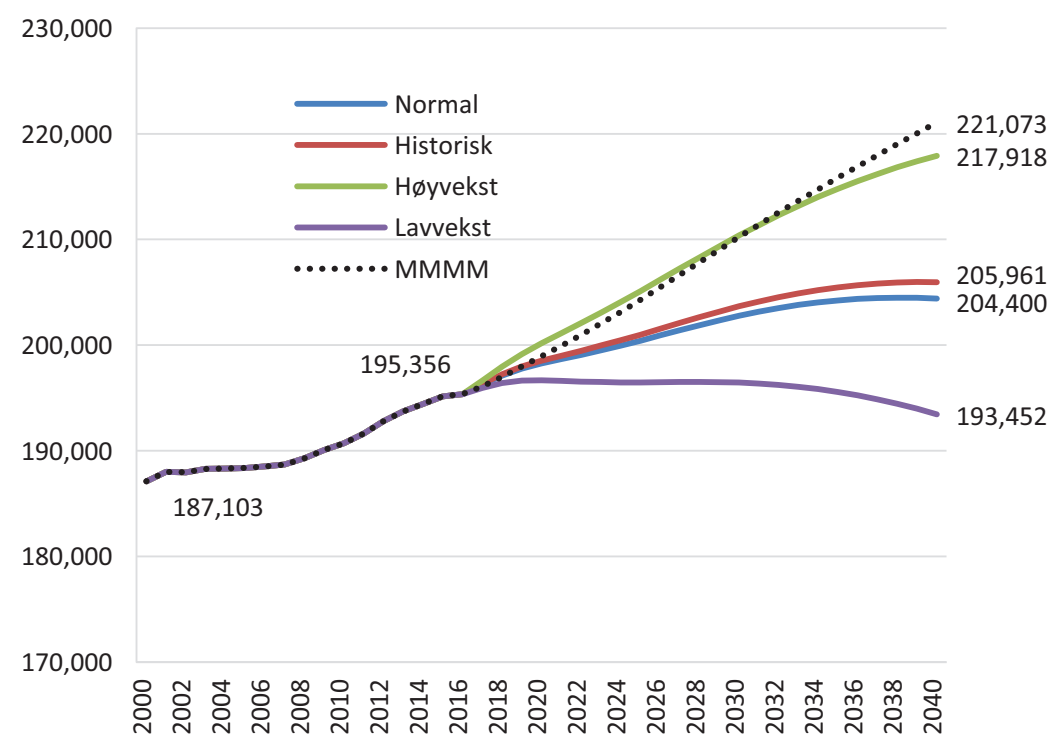

Figur 4.65 Scenarioer for befolkningsutvikling i Hedmark. 
bra å sette urealistiske mål i samfunnsplanene. I tilfellet Hedmark ville et mål om å få samme befolkningsvekst som SSB framskriver, vært svært ambisiøst. I planleggingen legger ofte fylker og kommuner SSBs framskrivinger til grunn, men de setter gjerne mål som ligger over middelframskrivingen, fordi de tenker seg at den framskrevne veksten kan stimuleres gjennom ulike tiltak.

Da vi først utviklet attraktivitetsmodellen, var hensikten å få fram forskjellen i framtidig vekst ved ulike attraktivitetsverdier. Tanken var at dette skulle representere stedenes handlingsrom. Siden vi hadde historiske attraktivitetsverdier, hadde vi grunnlag for å beregne hvor mye det er mulig å påvirke framtidig utvikling i folketall og arbeidsplasser. Vi ønsket også å beregne framtidig utvikling for steder med helt nøytral attraktivitet (normalscenarioet). Vi forventet at vårt normalscenario og historiske scenario (for steder med normale attraktivitetsverdier) skulle ligge tett opp mot $4 \mathrm{M}$. Da vi oppdaget at det var ganske store avvik mellom vår modell og SSBs framskrivinger, ble vi litt bekymret for at det skyldtes svakheter i vår modell.

Når innvandringen til Norge skal avta i de neste årene, mens utvandringen skal øke, slår dette spesielt negativt ut for Oslo. Det er fordi Oslo har hatt høy innvandring tidligere (som blir framskrevet), og fordi Oslo har en stor andel av innvandrere i befolkningen (Innvadrere har høyere sannsynlighet for å utvandre). Ettersom Oslo ikke har hatt nevneverdig netto innenlands flytting de siste årene, er det heller ikke framskrevet noen innenlands nettoflytting de neste årene. I attraktivitetsmodellen vil redusert nettoinnvandring til Oslo føre til at netto innenlands nettoflytting blir høyere. Oslo skal etter denne logikken få forholdsvis høy nettoinnflytting uansett, fordi arbeidsplassveksten er forventet å bli høy, og fordi Oslo har strukturelle betingelser som tilsier høy netto innflytting. 



\section{KAPITTEL 5}

\section{Hva skaper attraktivitet?}

Vi har så langt vist hvordan vi kan lage en modell for å identifisere og måle attraktiviteten i et område. Vi opererer med to typer av attraktivitet: attraktivitet for bosetting og attraktivitet for næringsliv. Attraktiviteten for næringsliv kan også deles opp i ulike bransjer og næringstyper. Metoden vi bruker, er først å lage en modell som beregner den forventede utviklingen basert på strukturelle forhold. Dernest ser vi på avviket mellom den faktiske og den forventede utviklingen på stedet. Steder som har mer innflytting enn forventet, blir da attraktive. Noe har gjort at stedet trekker til seg flere innflyttere enn arbeidsplassveksten og de strukturelle forholdene tilsier. Steder som har sterkere arbeidsplassvekst enn forventet ut fra befolkningsvekst og bransjestruktur, blir på samme måte karakterisert som attraktive for næringsliv. Noe har medført at slike områder har fått sterkere vekst i næringslivet enn «normalt». I arbeidet med å konstruere modellen har vi forsøkt mange forklaringsfaktorer som vi ikke har funnet signifikante.

Har vi fått med de viktige og relevante strukturelle forklaringsfaktorene? Det er naturligvis et svært viktig spørsmål. Dersom det finnes strukturelle forklaringsfaktorer som vi ikke har fått med i modellen, vil også indikatorene for attraktivitet bli lite presise. Vi er også avhengig av at tallene vi putter inn i modellen, er korrekte. Dataregistrene er ikke perfekte, og det kan spesielt være feil i målingen av antall arbeidsplasser og pendling på kommunenivå. Det er en type usikkerhet vi må leve med når vi gjør statistiske analyser av denne typen data. I praksis må vi være forsiktige med å trekke konklusjoner ut fra små variasjoner og avvik. Men der vi ser ganske store avvik og systematiske forskjeller, kan vi være noe mer sikre.

\subsubsection{Attraktivitetsfaktorer}

Når vi skal lete etter faktorer som skal forklare hvorfor et sted er attraktivt, ser vi på en rekke egenskaper som er knyttet til stedet. Det vil være 
ulike egenskaper som gjør et sted attraktivt henholdsvis som bosted og for næringsliv. Det vil også kunne være ulike stedlige egenskaper som gjør et sted attraktivt for ulike næringer. Vi må regne med at det er ulike kvaliteter som er viktige, alt etter som hvilken type attraktivitet vi snakker om.

Hvorfor er noen steder mer attraktive enn andre å bo på og flytte til? Tilgang på arbeid er en faktor vi ikke har med som faktor for attraktivitet som bosted. Vi vet at tilgang på arbeid er en faktor som påvirker flytting, og vi har allerede beregnet effekten av dette gjennom at vi har arbeidsplassvekst på stedet i modellen, sammen med arbeidsplassvekst i naboområdet og arbeidsmarkedsintegrasjonen. I vår terminologi er derfor ikke forhold knyttet til arbeidsplasser noe som gjør et sted attraktivt som bosted. Vi er ute etter faktorer som kan forklare hvorfor noen steder trekker til seg flere innflyttere (eller holder på de som allerede bor der) utover det som kan forklares av arbeidsplassvekst og størrelse. Her er det et vell av faktorer som kan tenkes, og som blir påstått, å være av betydning. Eksempler kan være vakker natur, gode skoler og barnehager, kulturtilbud og andre fritidsaktiviteter, kafeer og shoppingmuligheter, et godt omdømme som bosted, god tilgjengelighet for boliger og lave boligpriser.

På samme måte vil det være et utall av faktorer som vil kunne gjøre et sted attraktivt for næringsliv.

\subsubsection{Kategorier av forhold som kan gjøre et sted attraktivt}

Som vi har vært inne på, er det en lang rekke med kvaliteter og egenskaper som kan tenkes å påvirke et steds attraktivitet. De fleste av disse egenskapene kan vi plassere i en av fire kategorier: areal og bygninger, ameniteter, omdømme og stedlig kultur og identitet. Ameniteter er et begrep som dekker mange ulike goder og tilbud som kan gjøre et sted attraktivt.

I tabell 5.1 har vi vist hvordan disse fire kategoriene kan kombineres med de tre attraktivitetsdimensjonene bosted, besøk og bedrift:

I tabellen har vi lagt inn noen få typiske eksempler på forhold som kan gjøre et sted attraktivt for de ulike attraktivitetstypene og kategoriene. Vi kunne ha lagt inn langt flere.

De fire kategoriene av attraktivitetsfaktorer har ulikt innhold alt etter hvilken type attraktivitet det er snakk om. Her har vi brukt de tre B-ene: bosted, besøk og bedrift. 
Tabell 5.1 Kategorier av forhold som kan gjøre steder attraktive, og eksempler for tre ulike typer av attraktivitet.

\begin{tabular}{llll}
\hline & Bosted & Besøk & Bedrift \\
\hline $\begin{array}{l}\text { Areal og } \\
\text { bygninger }\end{array}$ & $\begin{array}{l}\text { Boligtomter, arealer } \\
\text { og boliger }\end{array}$ & $\begin{array}{l}\text { Overnatting, hytter og } \\
\text { hyttetomter }\end{array}$ & $\begin{array}{l}\text { Næringsareal og } \\
\text { næringsbygg }\end{array}$ \\
$\begin{array}{l}\text { Komeniteter } \\
\text { Kommunale tjenester, } \\
\text { fritidstilbud, natur }\end{array}$ & $\begin{array}{l}\text { Attraksjoner og aktiviteter, } \\
\text { natur }\end{array}$ & $\begin{array}{l}\text { Service fra det offentlig og } \\
\text { fra private. Økonomiske } \\
\text { incentiver }\end{array}$ \\
$\begin{array}{l}\text { Omdømme } \\
\text { og identitet }\end{array}$ & Omdømme som bosted & $\begin{array}{l}\text { Omdømme for besøk, } \\
\text { destinasjonsmarkedsføring }\end{array}$ & Omdømme som næringssted \\
& optimisme & Gjestfrihet, service & $\begin{array}{l}\text { Risikovilje og vilje til } \\
\text { vekst, samarbeidsånd, } \\
\text { næringsvennlighet }\end{array}$ \\
\hline
\end{tabular}

Innenfor hver kategori er det ulike faktorer som påvirker de forskjellige attraktivitetsdimensjonene. Innenfor kategorien areal og bygninger er det naturligvis boliger og boligareal som har betydning for bostedsattraktiviteten, mens det er næringsbygg og næringsarealer som har betydning for attraktiviteten for bedrifter. Her har vi splittet næringsattraktiviteten i besøks- og bedriftsattraktivitet. Det er fordi det antakelig er helt andre faktorer som er viktig forbesøksnæringene, enn hvasomerviktigfor basisnæringene. Besøksnæringene vil bli direkte stimulert av en økning i besøkende. Dermed vil steder som får bygget mange fritidsboliger, få en økning i besøkende, som igjen gir større etterspørsel til besøksnæringene. Det finnes naturligvis mange måter å splitte opp næringslivet på, og en kan dele opp næringsattraktiviteten på tilsvarende måter. Datagrunnlaget for modellen er detaljert sysselsettingsstatistikk på bransjenivå, slik at det er lett å måle utviklingen i ulike bransjer.

En kunne også ha definert ulike typer bostedsattraktivitet for ulike grupper, som barnefamilier, høyt utdannede, kreative etc. For å måle attraktiviteten for disse ulike gruppene er det nødvendig å ha flyttestatistikk for de ulike gruppene.

For steder som har definert klare målgrupper for hvilke typer arbeidsplasser og hvilke typer innflyttere de ønsker, vil det være hensiktsmessig å definere smalere attraktivitetsdimensjoner.

I resten av dette kapitlet skal vi beskrive og gi eksempler på attraktivitetsfaktorer innenfor de fire kategoriene «Areal og bygninger», "Ameniteter», «Omdømme» og «Stedlig kultur og identitet». 


\subsubsection{Areal og bygninger}

Areal og bygninger er den kategorien som det er lettest å knytte til attraktivitet. For bostedsattraktivitet er forhold som tilgjengelige tomter, boliger, boligbygging og boligpriser stedlige egenskaper som ganske klart påvirker hvor attraktivt et sted er å flytte til.

Av og til kan en høre argumenter for at lave boligpriser er et forhold som gjør det attraktivt å flytte til et sted. Andre ganger kan høye boligpriser være et argument for at et sted er attraktivt, fordi de høye boligprisene viser at det er stor etterspørsel etter boliger i det aktuelle området. Når vi skal analysere boligprisenes betydning for bostedsattraktivitet her, må vi huske på at bostedsattraktiviteten ikke er målt med nettoflytting, men nettoflytting i forhold til forventet nettoflytting. Vi må også se på både tilbuds- og etterspørselssiden i boligmarkedet.

Vi skal først se på sammenhengen mellom boligbygging og boligpriser i kommunene. I figur 5.1 har vi satt inn alle kommuner som det finnes data for boligpriser for i SSBs statistikkbank. Det er også lagt inn en regresjonslinje som viser at det er en positiv sammenheng mellom pris og boligbygging. I kommuner der boligprisene er høye, bygges det generelt flere boliger enn i kommuner med lave boligpriser.

Oslo og kommunene i Akershus er markert i rødt. Vi kan se at kommuner som Oslo, Bærum, Asker og Skedsmo har høye boligpriser, uten at det bygges mange boliger. I kommuner som Ås, Ullensaker og Vestby bygges det langt flere boliger selv om prisene er lavere.

Det er da nærliggende å anta at det bygges for få nye boliger i kommuner som Oslo, Bærum og Asker til å realisere potensialet for innflytting. Siden etterspørselen er høyere enn tilbudet, øker prisene.

Hvis vi ser på bostedsattraktiviteten og boligbyggingen i disse kommunene, er det tydelig at sammenhengen er svært sterk. I tabell 5.2 har vi lagt inn et tall for boligbygging $i$ forhold til pris. Vi bruker da formelen fra regresjonen i figur 5.1. Boligbygging $-\left(0,0458^{*}\right.$ boligpris $\left.+1,2515\right)$. Innholdet $i$ parentesen vil da være forventet boligbygging i forhold til prisnivået i kommunen. Samtlige kommuner i dette området som har høyere boligbygging enn forventet ut fra prisene, har også positiv bostedsattraktivitet i perioden. Tilsvarende har alle kommunene med uventet lav boligbygging lav bostedsattraktivitet, unntatt Frogn. 


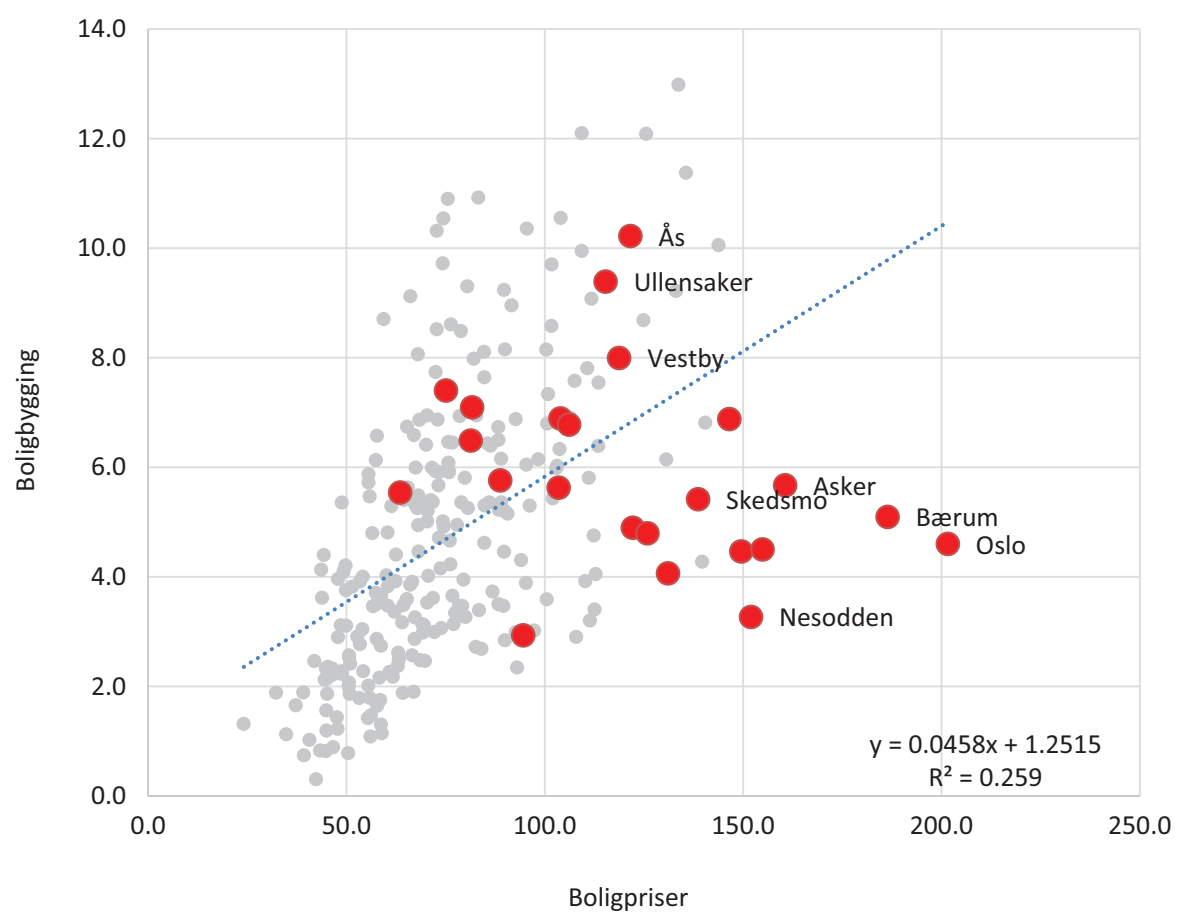

Figur 5.1 Kommunene plassert etter boligpriser (gjennomsnittlig pris per m2 for eneboliger mellom 2009 og 2015) og boligbygging (gjennomsnittlig antall fullførte nye boliger per 1000 innbyggere i perioden 2009-2015).

Neste spørsmål er hvorfor det ikke bygges flere boliger i kommuner som Oslo, Nesodden og Bærum. Det er nærliggende å forklare det med at det ikke er tilstrekkelig byggeklare tomter. Det betyr at mangel på byggeklare tomter er et forhold som kan forklare lav bostedsattraktivitet i kommuner i pressområder. Det er logisk at dersom det er en høy forventet nettoinnflytting i en kommune, vil den forventede nettoflyttingen ikke kunne realiseres dersom det ikke bygges tilstrekkelig antall nye boliger. Det blir rett og slett ikke nok boliger til å bosette den potensielle innflyttingen. I stedet blir prisene høye fordi etterspørselen er stor i forhold til tilbudet. Det som påvirker bostedsattraktiviteten, er da tilgjengelighet for boligareal. Det er en faktor som kommunen i stor grad kan påvirke, gjennom arealplanlegging og tilrettelegging. For kommuner innenfor store og voksende funksjonelle arbeidsmarkeder vil dette være en svært viktig forklaringsfaktor for bostedsattraktiviteten. 
Tabell 5.2 Bostedsattraktivitet og boligbygging i forhold til pris i kommunene i Akershus samt Oslo i perioden 2009-2015.

\begin{tabular}{lcc}
\hline Kommune & Bostedsattraktivitet & Boligbygging i forhold til pris \\
\hline Ås & 3,4 & 4,7 \\
Ullensaker & 2,9 & 4,4 \\
Aurskog-Høland & 2,7 & 5,4 \\
Nes & 2,1 & 2,9 \\
Eidsvoll & 1,5 & 7,3 \\
Hurdal & 1,4 & 6,5 \\
Vestby & 1,3 & 2,6 \\
Sørum & 0,9 & 1,5 \\
Gjerdrum & 0,7 & 1,6 \\
Nannestad & 0,4 & 2,0 \\
Fet & $-0,4$ & $-0,6$ \\
Lørenskog & $-1,1$ & $-2,4$ \\
Nittedal & $-2,0$ & $-2,4$ \\
Skedsmo & $-2,2$ & $-1,9$ \\
Ski & $-2,2$ & $-4,1$ \\
Enebakk & $-2,7$ & $-5,3$ \\
Asker & $-2,9$ & $-1,2$ \\
Rælingen & $-3,2$ & $-2,4$ \\
Frogn & $-3,6$ & 0,1 \\
Oppegård & $-3,8$ & $-3,2$ \\
Bærum & $-4,7$ & $-1,2$ \\
Nesodden & $-4,9$ & $-1,5$ \\
Oslo & $-5,9$ & $-1,8$ \\
\hline & & \\
\hline
\end{tabular}

I kommuner i distriktene er problemstillingen annerledes. De fleste distriktskommuner har rikelig med tomteareal til nybygging. Problemet i mange slike kommuner er at det bygges få boliger. Dette har blant annet sammenheng med at boligprisene er lave. Når boligprisene kanskje er bare en brøkdel av kostnaden til å bygge en ny bolig, vil de som bygger en ny bolig, ha et stort urealisert tap ved innflytting. Derfor kan det i mange 
distriktskommuner være vanskelig å skaffe seg en ny bolig. Mange som flytter fra kommunen, kan velge å bruke boligen til fritidshus i stedet for å selge fordi prisen er lav. Slike kommuner har boligmangel selv om det er rikelig med tilgjengelige og billige (enkelte ganger også subsidierte) tomter. Dermed blir også boligmassen gradvis eldre og mindre attraktiv. Potensielle innflyttere finner dermed ikke egnede boliger, selv om de er motivert for å flytte til kommunen.

\subsubsection{Hamarøy}

Hamarøy kommune er et interessant eksempel. Kommunen hadde stor fraflytting fram til 2010. Det ble ikke bygget en eneste bolig i årene fra 2008 til og med 2011. Hamarøy kommune løste dette ved å lyse ut et anbud for å bygge boliger til vanskeligstilte hvor utbygger også forpliktet seg til å bygge nye boliger for det ordinære boligmarkedet. Dermed ble det bygget 31 nye boliger i årene 2012, 2013 og 2014 (fra SSBs statistikk over fullførte nye boliger).

I figur 5.2 kan vi se at Hamarøy har fått et løft i den relative nettoflyttingen. Hamarøy er en liten kommune (1824 innbyggere i 2016) med ugunstige

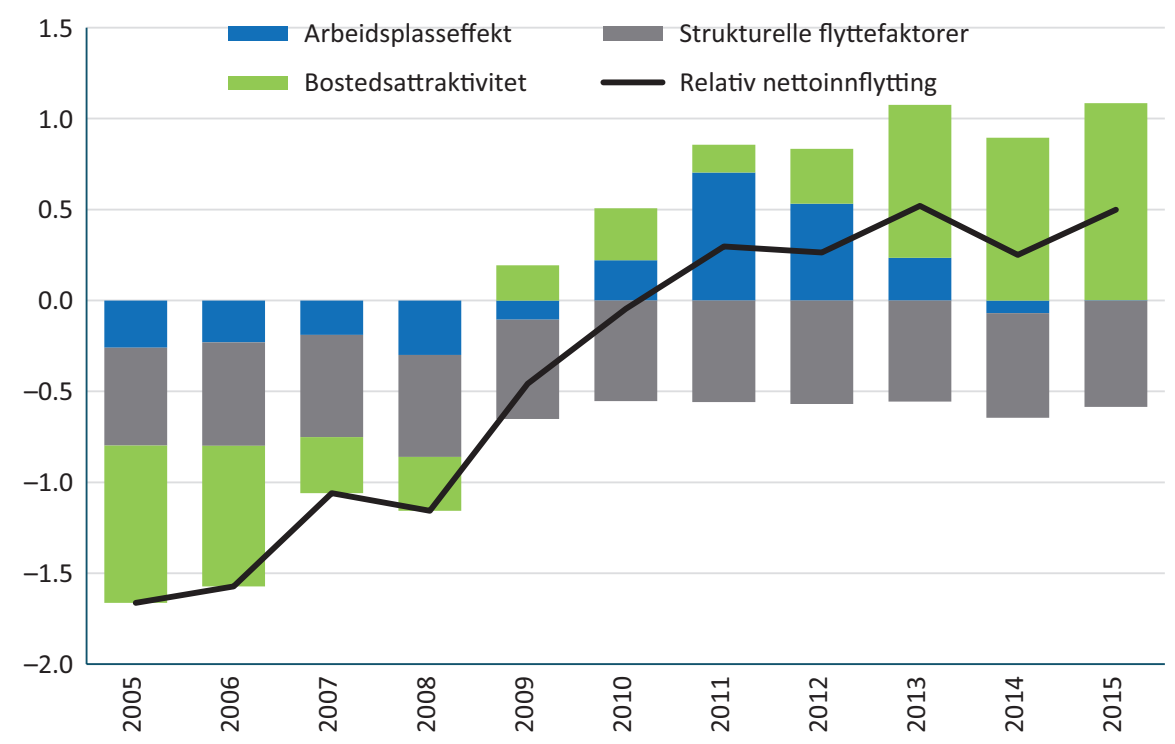

Figur 5.2 Relativ nettoflytting i Hamarøy, dekomponert i arbeidsplasseffekt, strukturelle flyttefaktorer og bostedsattraktivitet. 
forhold for nettoflytting, som vi kan se av at de grå søylene er negative. Arbeidsplassveksten var god i årene 2010-2013, noe som også var med på å løfte flyttetallene. I perioden 2013-2015 har bostedsattraktiviteten til Hamarøy blitt svært høy. Etableringen av Hamsun-senteret i 2009 har sikkert bidratt positivt, men den høye bostedsattraktiviteten hadde neppe kunnet la seg realisere uten den kreative løsningen for å få bygget flere boliger.

Forhold knyttet til boligmarkedet er dermed en viktig faktor for bostedsattraktiviteten både i sentrale strøk og i distriktene, men på ulike måter. Betydningen av boligbygging er spesielt sterk i kommuner der det er forventet høy innflytting, ettersom mangel på tilgjengelige boliger vil kunne kvele den potensielle innflyttingen.

Arealer og bygninger er også faktorer som kan forklare variasjoner i besøksog bedriftsattraktivitet. Både besøks- og bedriftsattraktivitet handler om næringsattraktivitet, men for ulike deler av næringslivet. For besøksattraktivitet vil overnattingskapasiteten og fritidsboliger være faktorer som påvirker antall besøkende. Antall besøkende har betydning for etterspørselen til bedrifter i besøksnæringene (handel, servering, aktiviteter og overnatting).

\subsubsection{Hytter}

Kommuner kan øke sin attraktivitet for besøk gjennom at det bygges nye fritidsboliger. En vil forvente at kommuner som har mange nye fritidsboliger, får en ekstra vekst i besøksnæringene, fordi det blir flere potensielle kunder. I figur 5.3 kan vi se på hvordan besøksattraktiviteten har vært i de ti kommunene hvor det er bygget flest nye fritidsboliger etter 2000.

Indikatoren for besøksattraktivitet er avvik mellom faktisk og forventet vekst i antall arbeidsplasser i besøksnæringene. Vi ser at ni av de ti kommunene med høyest antall nye fritidsboliger per innbygger har en positiv besøksattraktivitet. Åseral kommune har det høyeste antall nye fritidsboliger per innbygger. Det er bygget 903 nye fritidsboliger per 1000 innbyggere i Åseral, tett opp til én ny hytte per innbygger. Tydal er nummer ti på denne rankingen med 360 nye hytter per 1000 innbyggere.

Areal og bygninger er en faktor som også påvirker attraktiviteten til det øvrige næringslivet. Steder med god tilgjengelighet på lokaliteter og arealer til næringsvirksomhet har en fordel i forhold til steder hvor det er lite areal og få egnede lokaler for næringsvirksomhet. Dette har antakelig størst effekt på 


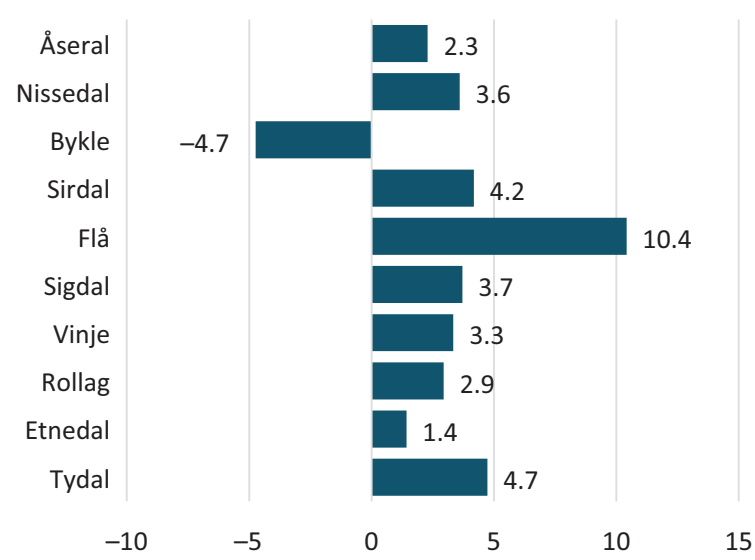

Figur 5.3 Besøksattraktiviteten til de ti kommunene med høyest antall nye fritidsboliger per innbygger i perioden 2000-2015.

steder der det er forventet sterk næringslivsvekst. På slike steder kan kanskje den forventede veksten i næringslivet utebli dersom det er mangel på arealer og lokaliteter, og veksten vil da kunne bli presset ut til nabokommuner som har bedre tilgjengelighet for arealer og lokaler. Dette vil være en parallell mekanisme til den vi beskrev tidligere for boligbygging.

I de siste årene har det vært sterk interesse for etablering av ulike næringshager som et tiltak for å stimulere næringsutvikling og nyetableringer. Slike næringshager tilbyr lokaler, men også andre fasiliteter som er tenkt å være attraktive for bedrifter. Det kan være felles kontortjenester, kantiner, diverse utstyr og rådgivingstjenester. Dette er goder som ikke direkte er lokaler eller arealer, og som hører under neste kategori av attraktivitetsfaktorer: ameniteter.

\subsubsection{Ameniteter}

Ameniteter er en fellesbetegnelse på ulike tilbud og goder som kan gjøre steder attraktive. På norsk er amenitet er lite brukt ord, men i den internasjonale forskningslitteraturen finnes det mye forskning om betydningen av det som på engelsk heter «amenities». Definisjonen kan være litt forskjellig. I vårt oppsett er tilgang på ameniteter skilt fra tilgang på arbeid og forhold som er knyttet til bygninger og arealer til utbygging. Vi har også definert ameniteter som fysiske og konkrete tilbud, noe som utelukker stedlige egenskaper av mer abstrakt 
natur som har med den lokale væremåten og kulturen å gjøre. Sistnevnte har fått en egen kategori som vi skal omtale senere.

Lista med ameniteter som kan gjøre et sted mer attraktivt som bosted, er lang. Alle offentlige servicetilbud er ameniteter. Slike tjenester finnes i ulike grad på forskjellige steder, og kvaliteten varierer. Samtidig har vi private servicetilbud og tilgang og tilgjengelighet til butikker og kafeer, som også varierer sterkt. Tilbudet av ulike kulturopplevelser, som kino, teater, biblioteker, konserter, museer og gallerier, har blitt ansett å være viktig. Naturen vil også kunne anses som en amenitet og varierer mellom steder. Stedlig arkitektur, særlig den estetiske verdien av bysentre, kan også være et fysisk karaktertrekk ved steder som påvirker attraktiviteten.

Ameniteter kan også ha betydning for besøksattraktivitet. En del av amenitetene som vi beskrev ovenfor, vil også være attraktive for besøkende, spesielt de som er knyttet til muligheter for ulike positive opplevelser og aktiviteter.

Bedrifter vil sannsynligvis bli tiltrukket av andre ameniteter. Her er det snakk om ulike tjenester og tilbud som bedriftene kan bruke i sin virksomhet. Næringshager som tilrettelegger spesielt for virksomheter og fasiliterer samarbeid, kan være en slik amenitet. Tilgang på finansiell støtte kan være en annen. I tidlige faser av attraktivitetsmodellen forsøkte vi å beregne effekten av differensiert arbeidsgiveravgift og tilgang på virkemidler fra Innovasjon Norge. Tanken var at dette er et strukturelt trekk som påvirker næringsattraktiviteten. Vi fant imidlertid ingen signifikant sammenheng mellom disse virkemidlene og næringsattraktivitet. Hvis vi hadde funnet klare sammenhenger, ville vi lagt dette inn som et strukturelt forhold for arbeidsplassutvikling. Det finnes imidlertid mange lokale og regionale økonomiske virkemidler. Kommuner har i varierende grad egne næringsfond som kan støtte nyetablerere og eksisterende næringsliv. En kommune som har sjenerøse virkemidler av denne typen, kan tenkes å påvirke arbeidsplassutviklingen i næringslivet. Det vil da være en attraktivitetsfaktor. Kommuner og regioner har også ofte eget personell som skal gi råd til og veilede etablerere og bedrifter. Dette kan være kommunale næringskonsulenter eller næringssjefer, eller det kan være ansatte i ulike typer næringsselskaper. Slike tjenester definerer vi også som en amenitet for næringslivet.

Etter at vi hadde spesifisert modellen og beregnet verdier for attraktiviteten til kommuner og regioner i Norge, forsøkte vi å finne statistiske sammenhenger 
mellom ulike ameniteter og stedlig attraktivitet. Vi skal spesielt omtale forsøket på å knytte en forbindelse mellom kulturtilbud og bostedsattraktivitet.

\subsubsection{Kulturtilbud og bostedsattraktivitet}

I 2011 utarbeidet Telemarksforsking for første gang Norsk kulturindeks. Denne indeksen måler antall og frekvens på en rekke kulturtilbud i norske kommuner, som konserter, teater, bibliotek, museer, kulturskole, antall kunstnere og liknende. Denne kulturindeksen ga oss et glimrende utgangspunkt for å finne ut om variasjonen mellom kulturtilbudet i norske kommuner hadde en positiv sammenheng med bostedsattraktiviteten. Vi fant ingen sammenheng, og publiserte et lite notat om den manglende sammenhengen: Skaper kultur attraktive steder? (2012). Konklusjonen var klar. Vi fant ingen sammenheng mellom kommuners kulturtilbud og kommunenes nettoflytting og bostedsattraktivitet. Kommuner med et godt kulturtilbud hadde ikke bedre flyttetall eller bostedsattraktivitet enn kommuner med lite kulturtilbud. Notatet skapte ganske mye debatt og ble kritisert og imøtegått av mange, men uten at det framkom konkret kritikk av metodene eller alternative undersøkelser som viser at kultur faktisk har betydning for nettoflytting eller bostedsattraktivitet.

Senere har vi undersøkt om lokalisering av høgskoler er en type amenitet som påvirker steders attraktivitet for bosted og næringsliv. Dette oppsummerte vi i notatet Hva betyr det for et sted å ha en høgskole? (2015). Igjen fant vi ingen slike påviselige sammenhenger. Kommuner med høgskoler hadde som gruppe ikke bedre attraktivitet for bosetting eller næringsliv.

Det har vist seg å være vanskelig å påvise signifikante sammenhenger mellom ameniteter og attraktivitet. Dette tror vi kan bero på to forhold. For det første er det som nevnt en lang rekke med ameniteter som kan påvirke steders attraktivitet. Det er naturlig å anta at det er den samlede mengden og kvaliteten på amenitetene som teller til slutt. Når antallet ameniteter er mange, vil effekten av en enkelt amenitet være vanskelig å påvise fordi den enkelte ameniteten bare er en av mange aktive faktorer i denne gruppen.

Et annet forhold som kan ha betydning for de manglende sammenhengene, er at vi har sammenliknet nivået og ikke endringene. Da vi så på betydningen av kulturtilbud, så vi om det var sammenheng mellom nivået på kulturtilbudet og bostedsattraktivitet. Det vi ikke har hatt anledning til å undersøke ennå, er om en økning eller forbedring av kulturtilbudet har en positiv sammenheng 
med bostedsattraktiviteten. Det kan vi ikke utelukke med de analysene vi har gjort. Problemstillingen om det er nivå eller endring som skaper attraktivitet, er et viktig spørsmål som vi skal vie et eget kapittel litt senere.

Selv om vi ikke har funnet signifikante sammenhenger mellom ameniteter og attraktivitet, vil vi slettes ikke avskrive betydningen av amenitetene. For å undersøke dette trenger vi imidlertid bedre kvantitative data enn hva vi har i dag.

\subsubsection{Omdømme}

Et steds omdømme er den tredje kategorien av attraktivitetsfaktorer. Omdømme forstås da som hva andre enn stedets innbyggere assosierer og tenker om stedet. Hva innbyggerne selv tenker, er en faktor i den fjerde og siste kategorien, som vi skal omtale i kapittel 5.1.6.

Omdømmet kan påvirkes, og mange kommuner har hatt sine omdømmeprosjekter. Stikkord har ofte vært «stedsbranding» og «få kommunen på kartet». Metoder har vært hentet fra kommunikasjons- og markedsføringsfagene. I de siste årene synes det som om slike omdømmestrategier har gått av moten. Steders omdømme kan likevel kanskje ha noe å si for et steds attraktivitet. Det er kanskje lettest å se for seg at et steds omdømme har betydning for besøksattraktivitet. Beslutninger om besøk skjer antakelig langt mer spontant enn beslutninger om skifte av bosted eller flytting av en bedrift. Det fleste steder er tilknyttet lokale og regionale destinasjonsselskaper. Det reflekterer at en har tro på at omdømmet som besøkssted kan påvirkes, og at en kan påvirke folks motivasjon til å besøke stedene gjennom aktiv markedsføring.

Omdømmestrategier flyter sammen med rene salgsstrategier. Et eksempel på en salgsstrategi rettet mot bosetting er virksomheten til selskapet Placement AS. Placement har hatt mange tilflytterprosjekter for kommuner i Norge der målet har vært å få innflytting av nederlendere til kommunene. Et interessant eksempel er Fyresdal kommune.

\subsubsection{Fyresdal kommune}

I figur 5.4 kan vi se analysen av bostedsattraktiviteten i Fyresdal. Fyresdal var en av de første kommunene som hadde tilflytterprosjekt via Placement da selskapet startet opp i 2003. Resultatene var tilsynelatende svært gode. 


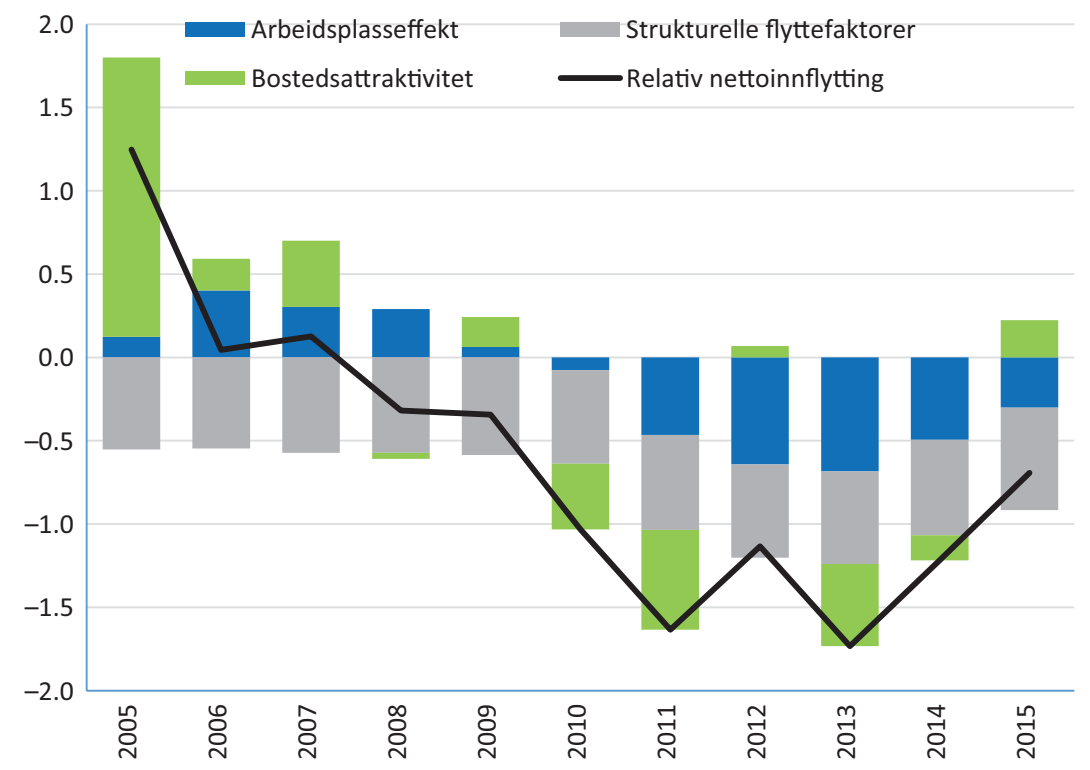

Figur 5.4 Analyse av nettoflytting til Fyresdal. Tre års glidende gjennomsnitt.

Fyresdal fikk en svært høy bostedsattraktivitet i perioden 2003-2005, og mange nederlendere flyttet til Fyresdal i denne perioden. Det er vanskelig å se dette som annet enn et direkte resultat av flytteprosjektet. I dag, i 2016, bor mange av de innflyttede nederlenderne fra denne perioden fremdeles $\mathrm{i}$ Fyresdal. Etter 2007 har bostedsattraktiviteten i Fyresdal variert mellom negativ og positiv, etter at Fyresdal avsluttet prosjektet. Vi kan dermed se resultatene av innflytterprosjektet direkte reflektert i bostedsattraktiviteten til Fyresdal. Det finnes ikke mange eksempler på at vi kan lese resultater av slike prosjekter i statistikken.

Salgsstrategier kan også rettes mot å lokke bedrifter til å etablere eller flytte virksomheter til steder. Ofte blir dette omtalt som akkvisisjonsstrategier. Det er ikke så lett å finne eksempler på at slike akkvisisjonsstrategier har vært vellykket. Et eksempel på en typisk akkvisisjonsstrategi er Telemark fylkeskommunes prosjekt som pågikk fra 2013 til 2016, der de engasjerte kommunikasjonsselskapet First House til å markedsføre og selge Telemark til utenlandske bedrifter. Prosjektet fikk en del omtale i pressen i 2015 og 2016 fordi det viste seg at prosjektet ikke hadde resultert i noen større etableringer i Telemark, til tross for at kostnadene var flere millioner. 
Når en forsøker å analysere om steders omdømme har en reell effekt på attraktiviteten, er det verd å dvele ved om steders omdømme er et resultat av de faktiske kvalitetene på stedet, eller om steders omdømme avviker fra det som er forventet ut fra de faktiske kvalitetene. Hvis omdømmet er en faktisk og realistisk gjenspeiling av de faktiske kvalitetene, vil det være kvalitetene som er årsaken til omdømmet. Da vil omdømmet forbedres av seg selv dersom en forbedrer og øker de faktiske stedskvalitetene.

Hvis omdømmet avviker fra de faktiske kvalitetene, og omdømmet også kan påvirkes gjennom ulike virkemidler og kampanjer, er det langt lettere å forsvare en omdømmestrategi. Dette gjelder spesielt for steder som har gode kvaliteter som ikke er kjent, og som derfor ikke reflekteres i omdømmet. «Hvis folk hadde vist hvor fint vi har det her, ville mange ha flyttet hit», er et typisk utsagn fra en slik kommune. Slike og liknende utsagn har vi hørt mange steder. Med dette som utgangspunkt gir det mening å investere i å gjøre stedets kvaliteter kjent for omverdenen. Vi har imidlertid en sterk mistanke om at mange steder overvurderer sine egne kvaliteter, og at omdømmet i de fleste tilfeller er fortjent. Vi har aldri vært på steder som mener at de har et ufortjent godt omdømme - at stedet ikke er så fint som omverdenen tror. Det er simpelthen ikke logisk at de fleste steder har et ufortjent dårlig omdømme, samtidig som at ingen steder har et ufortjent godt.

Drammen kommunes omdømmeprosjekt er godt kjent, og regnes kanskje som skoleeksemplet på et vellykket omdømmeprosjekt. I Drammen arbeidet de imidlertid i årevis med å forbedre kvaliteten i byen gjennom store, kostbare og fysiske investeringer. Behovet for å arbeide med markedsføring og omdømmet kom som en følge av at byen faktisk ble forandret, og at omverdenen trengte å bli informert om dette. Drammensprosjektet gir derfor langt mer mening enn steder som starter med omdømmekampanjer først, uten forutgående reell kvalitetsforbedring av noe slag. Virket det i Drammen? Vi skal komme tilbake til eksemplet Drammen senere.

\subsubsection{Stedlig kultur og identitet}

Den siste kategorien av attraktivitetsfaktorer har vi kalt stedlig kultur og identitet. Her er ikke kulturbegrepet knyttet til kulturtilbudet på stedet (det tilhører kategorien ameniteter), men til kjennetegn ved den lokale kulturen i antropologisk forstand. Kategorien kultur og identitet er knyttet til relasjonelle 
og emosjonelle forhold blant innbyggerne på stedet. Denne kategorien er det naturligvis vanskelig å forske på med statistiske metoder. Men selv om dette er vanskelige forhold å måle, kan naturligvis stedets kultur og identitet ha stor betydning for stedets attraktivitet.

Kulturelle forhold som kan ha betydning, er for eksempel samarbeidsånd, åpenhet, gjestfrihet, risikovilje og optimisme. En kan tenke seg at steder som er preget av samarbeidsånd, risikovilje og optimisme, vil ha lettere for å oppnå vekst i næringslivet. Det at bedriftene på et sted samarbeider og støtter hverandre, kan gi en fordel i forhold til andre steder, hvor bedriftene i liten grad samarbeider. Steder med bedrifter som preges av optimisme og risikovilje, vil antakelig få mer investeringer og dermed mer vekst enn steder der bedriftene er pessimistiske og har liten vilje til å ta risiko. På samme måte kan vi tenke oss at steder som er preget av gjestfrihet og åpenhet, kan være mer attraktive å besøke og flytte til enn steder uten disse kvalitetene.

Stedsidentitet er et begrep med mange tolkninger. Vi kan skille mellom steder hvor de fleste innbyggere har en sterk identitet med bostedet, og steder der befolkningen i liten grad er knyttet til stedet. En kan tenke seg at steder hvor innbyggerne er sterkt knyttet til stedet, er mindre tilbøyelige til å flytte, selv om de kanskje har mistet arbeidet. Hvis stedsidentiteten er sterk, velger kanskje mange å bli boende selv om arbeidstilbudet er svakt. De vil kunne tenkes å være villige til å akseptere å pendle langt for å få arbeid i stedet for å flytte. På steder med svak stedsidentitet vil innbyggerne antakelig ta flyttebeslutningen raskere når det oppstår ulike problemer. Stedsidentiteten kan også si noe om innbyggernes motivasjon til å delta i frivillig arbeid for å styrke stedet på ulike måter. Dugnadsånd og sterk stedlig identitet hører antakelig sammen.

\subsubsection{Kommunikasjoner?}

Et tema som jevnlig dukker opp når det er snakk om vekstdrivende faktorer, er infrastruktur og kommunikasjoner, og da spesielt vei og jernbane. Steder som har utsikter til å få forbedret sine kommunikasjoner til omverdenen, har ofte store forventninger til at de forbedrede kommunikasjonene skal føre til vekst. Dette gjelder spesielt der det er snakk om forbedrede kommunikasjoner til større byer som har et stort arbeidsmarked. I slike tilfeller ser mange steder for seg økt pendlingsbasert innflytting. I noen tilfeller blir dette virkelighet også. Gode eksempler på det er Rennesøy og Finnøy kommuner. 
I figur 5.5 er nettoflyttingen til Rennesøy og Finnøy analysert med attraktivitetsmodellen. Rennesøy ble knyttet til fastlandet via nye tunneler i 1992. Fra 1996 ble passeringene også bomfrie. Finnøy fikk fergefri fastlandsforbindelse i 2009. Rennesøy har hatt den høyeste bostedsattraktiviteten av alle norske kommuner i perioden 2000-2014. Relativ netto innflytting har i enkelte år nærmet seg tre prosent av folketallet. Figur 5.5 viser at arbeidsplassveksten i Rennesøy har betydd svært lite for nettoflyttingen. Finnøy hadde lav bostedsattraktivitet fram til og med 2007. I perioden 2005 til 2007 var det lavere nettoflytting til Finnøy enn forventet. Etter 2007 har innflyttingen til Finnøy blitt svært mye bedre, men vi ser av figuren at arbeidsplassutviklingen i Finnøy har hatt svært liten betydning for denne innflyttingen. Finnøy hadde en positiv arbeidsplasseffekt fra 2010 til 2012, men de tre siste årene har arbeidsplasseffekten vært negativ.

Eksemplene Rennesøy og Finnøy kan gi et inntrykk av at forbedrede kommunikasjoner har svært stor betydning for bostedsattraktivitet og befolkningsvekst. Det er imidlertid noen spesielle forhold som gjør at de forbedrede kommunikasjonene får så stor effekt i disse tilfellene. Rennesøy og Finnøy er forholdsvis små kommuner; de hadde henholdsvis 3111 og 2865 innbyggere i 2000. De forbedrede kommunikasjonene knyttet kommunene direkte til arbeidsmarkedet i den funksjonelle Stavangerregionen. Stavangerregionen har
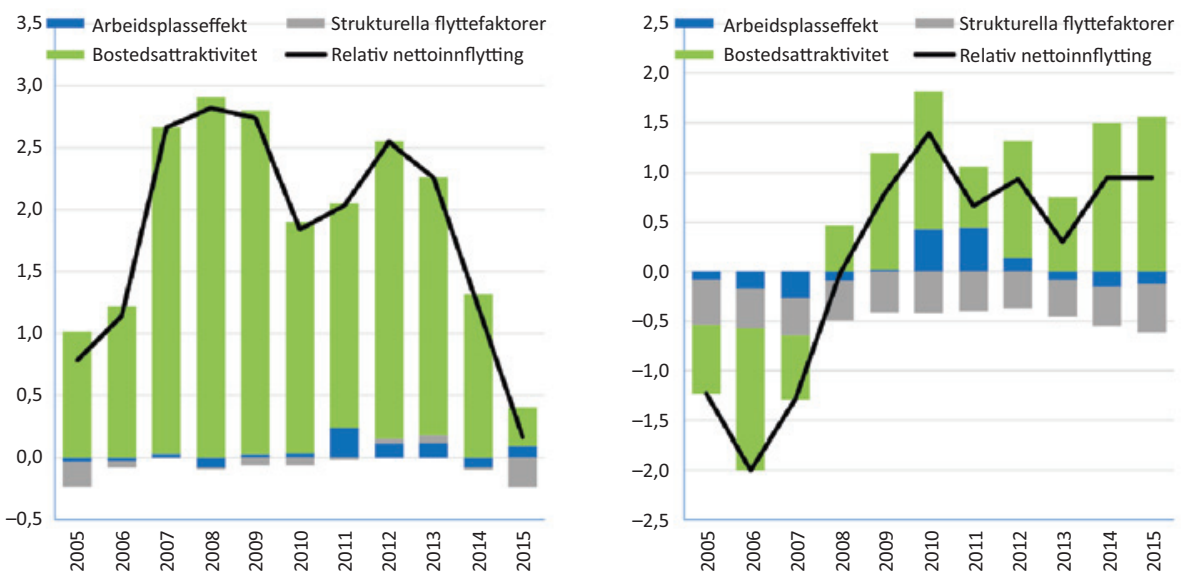

Figur 5.5 Analyse av relativ nettoflytting til Rennesøy (til venstre) og Finnøy (til høyre). 
hatt en nærmest ekstrem arbeidsplassvekst etter 2000. Sist, men ikke minst: Boligbyggingen i sentrale kommuner i Stavangerregionen, som selve Stavanger, Sola og Randaberg, har ikke vært sterk nok til å dekke etterspørselen. Kanskje er også de tilgjengelige boligtomtene i Rennesøy og Finnøy kommuner spesielt attraktive. Dette er faktorer som har gjort at effekten av de forbedrede kommunikasjonene har blitt svært sterk. Det er dermed ikke tilstrekkelig med forbedrede kommunikasjoner alene.

På Østlandet er det skapt stor optimisme om at nye og forbedrede kommunikasjoner til Oslo skal resultere i økt pendlingsbasert innflytting (bostedsattraktivitet). Forbedrede og hurtigere jernbaneforbindelser og vei vil redusere reisetiden til Oslo. Denne optimismen deles av store deler av Østfold, sørlige deler av Hedmark og Oppland, sørlige Buskerud og nordlige deler av Vestfold. Det er altså mange steder som har forventninger om økt pendlingsbasert innflytting samtidig. Hvis optimismen skal realiseres alle disse stedene, må det bli en sterk reduksjon av nettoflyttingen til Oslo og Akershus på samme tid. Tidligere har vi vist at Oslo og mange kommuner i Akershus har hatt en overraskende lav nettoflytting (bostedsattraktivitet), og at dette etter all sannsynlighet kommer av manglende nybygging av boliger, og at dét igjen antakelig er forårsaket av at det har vært for lite tilgjengelig areal til nybygging. Dersom en lykkes i å bygge flere boliger i Oslo og Akershus de neste årene, vil Oslo og Akershus få en økt nettoinnflytting, og da vil bostedsattraktiviteten i de tilliggende områdene bli redusert. Et annet viktig moment i denne sammenhengen er at befolkningsveksten i Norge er forventet å bli lavere de neste årene enn i de siste ti årene. Dersom landets befolkningsvekst blir redusert, vil Oslo og Akershus ha kapasitet til å «ta» en større andel av veksten enn tidligere, selv om boligbyggingen ikke økes, men bare opprettholdes på samme nivå. Områdene som grenser til Akershus, vil derfor kunne oppleve fallende bostedsattraktivitet selv om kommunikasjonene blir forbedret.

\subsubsection{Bro mellom to øyer}

Vi skal forsøke å vise hvordan effekten av kommunikasjoner er i attraktivitetsmodellen. Vi bruker et tenkt eksempel: to øyer som tidligere hadde svært dårlig kommunikasjon, og som det i praksis var umulig å pendle mellom. Vi tenker oss at det blir bygget en bro mellom øyene, som gjør transporten rask og enkel. 
Øyene vil da samlet sett få bedre strukturelle betingelser for bosetting fordi arbeidsmarkedsintegrasjonen brått blir bedre. I attraktivitetsmodellen øker ikke bostedsattraktiviteten, men de strukturelle betingelsene for bosetting blir bedre. Resultatet blir imidlertid det samme: Øyene får samlet sett en forbedret nettoflytting. Samtidig blir den enkelte øys bostedsattraktivitet en viktigere faktor enn før, mens betydningen av næringsattraktiviteten blir mindre. La oss forestille oss at det er ulike kvaliteter på øyene, som gjør at den ene er mer attraktiv som bosted enn den andre. Da vil hele flyttegevinsten kanskje gå til den mest attraktive øya. Den minst attraktive av øyene vil kunne oppleve økt utflytting. Befolkningen på den minst attraktive øya vil da kunne flytte til den mest attraktive øya og pendle til jobben. Det valget hadde de ikke før broa kom. Et sted får dermed nødvendigvis ikke økt befolkningsvekst med bedre kommunikasjoner. Det er faktisk mulig at resultatet blir redusert befolkningsvekst.

Forbedrede kommunikasjoner vil forbedre de strukturelle betingelsene for flytting samlet sett for stedene som blir bedre forbundet, men konkurransen om innbyggerne vil bli sterkere. Det mest attraktive stedet vil da kunne innkassere hele gevinsten. Steder som har utsikt til å få forbedret sine kommunikasjoner, bør derfor ikke lene seg tilbake og ta økt vekst og innflytting som en selvfølge. Tvert imot blir arbeidet med å skape bostedsattraktivitet brått viktigere enn før. Dessverre har vi sett mange eksempler på steder som regner med at de nye kommunikasjonene vil skape vekst automatisk. Det gjelder spesielt lokalpolitikere som har vunnet den politiske kampen og fått sitt prosjekt inn i nasjonal transportplan.

Kommunikasjoner er derfor ikke med på oversikten over attraktivitetsfaktorer. Effektene av kommunikasjoner er på en måte innbygget i modellen, gjennom at den tar hensyn til arbeidsmarkedsintegrasjonen. Forbedrede kommunikasjoner vil da gi som resultat at de strukturelle betingelsene for bosetting blir bedre. Forbedret kommunikasjon gir ikke bedre attraktivitet for besøk eller næringsattraktivitet ifølge modellen. Det er fordi vi gjennom de empiriske analysene ikke har funnet at $ø$ kt arbeidsmarkedsintegrasjon eller størrelse på det funksjonelle arbeidsmarkedet har noen systematisk effekt på arbeidsplassutviklingen i næringslivet. Det er noe overraskende, ettersom det finnes andre studier og forskningsrapporter hvor arbeidsmarkedsregionens størrelse er av stor betydning for blant annet produktivitet og vekst i næringslivet. 


\subsubsection{Nivå eller endring?}

Vi har omtalt de mislykkede forsøkene på å finne positive sammenhenger mellom kulturtilbud og bostedsattraktivitet og positive sammenhenger mellom lokalisering av høgskole og attraktivitet. Vi har også forsøkt å se om kommuner med godt klima (mange dager med sol og +20 grader) har høyere bostedsattraktivitet enn andre, og om beliggenhet ved kyst er attraktivt. Graden av befolkningskonsentrasjon internt i kommuner har vi også forsøkt å teste. Hypotesen var at kommuner som i stor grad har befolkningskonsentrasjon i ett senter, er mer attraktive enn kommuner der befolkningen bor spredt. Så langt har slike tester ikke gitt noe resultat. Som vi har vært inne på tidligere, kan dette skyldes at det ikke er nivået som sådan som påvirker attraktiviteten, men endringene. Det vil si at en kommune hvor det bygges en helt ny høgskole, vil være attraktiv i en periode, men at effekten på attraktiviteten avtar etter noen år. Høgskolestrukturen i Norge har vært ganske stabil i flere tiår. Steder som har høgskole i dag, hadde høgskoler også for 10, 20 og 30 år siden.

Det kan derfor se ut til at nivået til de mange forskjellige attraktivitetsfaktorene ikke har noen særlig betydning, men at det er endringene som skaper attraktiviteten. Steder blir dermed ikke attraktive fordi de har noe eller er noe. De blir attraktive fordi de skaper noe nytt eller forbedrer kvaliteten på noe. Steder kan dermed ikke regne med å bli attraktive fordi de har fin natur, godt klima, et rikt kulturliv eller en sterk gründerkultur. De blir attraktive dersom de forbedrer eller tilfører noe nytt.

Troen på at naturen er en viktig faktor, er sterk i Norge. Etter vår erfaring vil de fleste kommuner i landet trekke fram sin spesielt vakre natur som et pre for sin kommune. Kanskje til og med alle har rett, men hvis det er endring som skaper attraktivitet, hjelper det ikke å ha en fin natur. Naturen må bli finere.

Det bringer oss til en annen type endring som kan ha betydning for attraktivitet: Folks oppfatning av hva som er attraktivt, kan endres over tid. Følgende sitat kan belyse dette:

"Helgeland er det for Naturskjønhed mest blottede District $i$ Nordlandene, når undtages Lofoten, hvor Tanken om Natur-skjønhed ikke kan opstaae uden som et savn. Lofoten er så blottet for Natur-Skjønhed som vel muligt".

Utsagnet er tillagt Amtmann Blom i 1827. Oppfatningen av Lofotens skjønnhet har endret seg siden det. En slik endring kan tenkes å ha påvirket Lofotens 
attraktivitet som bosted. Hvis den allmenne oppfatningen av Lofoten og naturen der endret seg fra at stedet var blottet for naturskjønnhet, til at det var et av de vakreste steder på jord, vil en kunne tenke seg at det også påvirket folks tilbøyelighet til å flytte til stedet. Det har nok ikke påvirket Lofotens bostedsattraktivitet i nyere tid, ettersom Bjørnsterne Bjørnson allerede i 1869 proklamerte at Lofoten var «vakrest av alt» når det gjaldt naturskjønnhet. Naturen i Lofoten synes på den måten å ha blitt finere mellom 1827 og 1869. Det kan ha påvirket bostedsattraktiviteten i denne perioden, men i de siste 150 år har Lofoten være ansett for å være et vakkert sted, og denne effekten er dermed for lengst brukt opp.

Et nyere eksempel kan være den økte interessen for å oppleve nordlys. Nordlyset er ikke et nytt fenomen i Nord-Norge. Men interessen for å oppleve nordlyset har tilsynelatende økt. I pressen har det blitt meldt om sterk $ø$ kning av «nordlys-turisme» til Nord-Norge de siste årene. Nordlyset har dermed bidratt til å øke bostedsattraktiviteten for landsdelen. Det er ikke fordi nordlyset har blitt sterkere eller vakrere, men fordi interessen blant publikum har økt.

Hovedhypotesen vår så langt er at årsakene til at noen steder er attraktive, er at det nylig har skjedd en endring til det bedre i en eller flere av de mange faktorene som påvirker attraktiviteten, og at nivået kanskje ikke betyr særlig mye. Vi har så langt ikke kunnet bekrefte denne hypotesen med statistiske analyser. For å kunne gjøre det må vi ha data for endringer av virksomme attraktivitetsfaktorer på stedene.

\subsubsection{Hvordan skape endring? Hvem skaper endring?}

Hvis vi aksepterer at det er endringer som skaper attraktivitet, betyr det at steder kan skape attraktivitet kun gjennom å gjennomføre endringer som faktisk skaper nye kvaliteter som øker attraktiviteten. Men endringer skjer naturligvis hele tiden på alle steder, derfor kan et sted forvente økt attraktivitet bare hvis det evner å skape flere og mer betydningsfulle endringer enn de fleste andre steder gjør.

Det betyr antakelig at det må gjennomføres ganske betydelige endringer før en kan forvente synlige resultater i statistikken. Da blir det avgjørende i hvilken grad stedet greier å mobilisere størst mulig ressurser. 


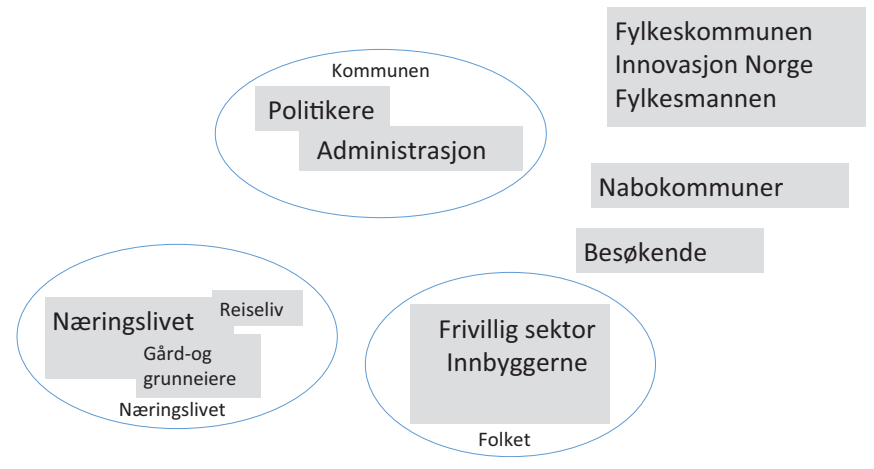

Figur 5.6 Endringsaktører.

Ofte startes endringsprosesser i kommunen, gjerne i forbindelse med ny samfunnsplan, planstrategi, næringsplan eller liknende. Kommunen definerer mål for sin samfunnsutvikling og utarbeider strategier og tiltak. Kommunen er naturligvis en svært viktig samfunnsaktør på mange måter. For det første er det kommunen, som gjennom sitt demokratisk valgte kommunestyre, har legitimitet til å lage mål for samfunnsutviklingen. For det andre driver kommunen mange viktige velferdstjenester som har betydning for attraktiviteten. For det tredje har kommunen store ressurser i form av kompetanse, personell og økonomiske midler. Kommunen er antakelig viktigere dess mindre stedet er. Kommunen, med sine politikere og administrasjon, er dermed den mest sentrale samfunnsaktøren for å skape et attraktivt sted.

Selv om kommunen er den viktigste samfunnsaktøren for utvikling av attraktivitet, er den langt fra den eneste. Når vi snakker om næringsattraktivitet, er næringslivet selv den viktigste aktøren. Det er opplagt at kommunen har begrensede virkemidler tilå påvirke næringsutviklingen alene. Kommunen har arealplaner og myndighet til å gi byggetillatelser. Det vil kunne fungere som en effektiv begrensning av næringsutvikling i noen tilfeller, men kommunen har lite av virkelig stimulerende virkemidler som kan skape vekst $\mathrm{i}$ næringslivet. Dermed er det vanskelig å tenke seg en kommune som greier å skape høy næringsattraktivitet uten å være i et nært partnerskap med næringslivet.

Næringslivet er ikke bare én aktør, men et stort antall enkeltbedrifter. På noen steder er næringslivet organisert i næringsforeninger eller liknende. Slike næringsforeninger har styre, generalforsamlinger og av og til også lønnet 
personell som kan representere næringslivet samlet. Det er en stor fordel, ettersom en slik organisasjon har legitimitet til å opptre på næringslivets vegne. Slike næringsforeninger er dermed ofte verdifulle partnere for kommunen når det skal skapes næringsattraktivitet på stedet. Næringsforeningen kan også kommunisere med sine medlemsbedrifter, og vil som oftest ha mye større legitimitet og tillit fra bedriftene enn fra kommunen selv. Mange steder har også sine egne destinasjonsselskaper som arbeider spesielt for besøksnæringene. Ofte er dette selskaper som er eid og drevet, helt eller delvis, av reiselivsbedrifter. Slik selskaper kan representere og samordne deler av reiselivet, og da spesielt besøksnæringene.

Noen typer næringsliv har kanskje spesielt stor betydning, som gård- og grunneiere, eiendomsutviklere og eiendomsinvestorer. Dette er aktører som kan gjennomføre synlige og viktige endringer, gjennom både nybygging og omforming av sentre, etablering av ny næringseiendom, bygging av boliger og investeringer i for eksempel skianlegg og større hyttefelt.

Frivillig sektor kan også være en stor ressurs i samfunns- og attraktivitetsutvikling. Da tenker vi kanskje spesielt på bostedsattraktiviteten, der frivillig sektor utgjør verdifulle fritidstilbud i seg selv, men også ressurser som kan settes inn i endringsprosesser. Frivillig sektor kan også ses på som representanter for «folket», ettersom kommunen vanskelig kan ha særlig mye kommunikasjon med enkeltpersoner.

I figur 5.6 over har vi illustrert hvilke endringsaktører som kan finnes på et sted, som har betydning for attraktiviteten. I tillegg til selve kommunen, næringslivet og folket, som vi har omtalt, har vi lagt inn tre grupper til: besøkende, nabokommuner og eksterne institusjoner som fylkeskommunen, Innovasjon Norge og fylkesmannen.

Besøkende er en gruppe som sjelden blir involvert i endringsprosesser på et sted. I noen tilfeller har kommuner forsøkt å opprette kommunikasjon og tiltak rettet mot hytteeiere. Det er en gruppe som kan tenkes å ha interesse av å utvikle stedets attraktivitet. Det vil kunne gi flere ameniteter for hytteeierne og kanskje øke verdien til hytteeiendommene deres. Hytteeierne kan kanskje også tenkes å ha en uegennyttig interesse av å bidra til utviklingen. Kanskje de også har en viss identitet med stedet? Og kanskje kan denne stedsidentiteten utvikles og forsterkes?

Nabokommuner kan også være en ressurs. Svært mange kommuner er knyttet til et regionråd sammen med sine nabokommuner. I mange tilfeller er 
også næringsarbeidet organisert gjennom interkommunale næringsselskaper. Vi har dessuten vist gjennom attraktivitetsanalysene at arbeidsplassvekst i nabokommuner øker nettoflyttingen. En kommune kan dermed øke egen befolkningsvekst gjennom å bidra til arbeidsplassvekst i nabokommunen. Nabokommunen kan også naturligvis bidra tilbake.

Institusjoner som fylkeskommunen, Innovasjon Norge og fylkesmannen er kanskje de viktigste eksterne institusjonene. De representerer både kompetanse, personell og økonomiske midler som kan være med og støtte attraktivitetsutviklingen.

Som vi har vært inne på, er det steder som evner å skape endringer, som blir attraktive. Endringer krever ressurser. Dermed er det steder som greier å mobilisere alle ressurser og aktører, som har størst muligheter til å skape attraktivitet.

\subsubsection{Attraktivitet er relativt}

Et sted er attraktivt eller lite attraktivt i forhold til andre steder. Dermed vil resultatene av tiltak for å øke attraktiviteten på et sted i stor grad avhenge av hva andre steder gjør. Det faktum at stedlig attraktivitet er relativt i forhold til andre steder, gjør også at det aldri vil komme en oppskrift eller kokebok med konkrete tiltak på hvordan et sted kan bli attraktivt. Hvis det eksisterte en slik oppskrift som beviselig virket, ville alle steder tatt den i bruk. Da ville alle steder påvirket sin attraktivitet på samme måte, og ingen steder ville ha forbedret sin attraktivitet.

Eksemplet fra Fyresdal, som vi omtalte tidligere, er et godt eksempel. Da Fyresdal var først ute med å rekruttere nye innbyggere fra Nederland, virket dette tiltaket godt. Potensielle immigranter fra Nederland som ønsket å flytte til Norge, ble sluset til Fyresdal. I Fyresdal planla de nylig å gjenta suksessen de hadde hatt tidligere, men ga raskt opp: Etter at et stort antall kommuner hadde kopiert framgangsmåten, var det samme tiltaket ikke lenger effektivt. Potensielle immigranter fra Nederland har nå mange kommuner i Norge og Sverige å velge blant. Tiltaket som ga Fyresdal suksess i 2003, var dermed ikke særlig virkningsfullt i 2015.

Kopiering av «best case» er altså ingen lur strategi. Steder som bruker lang tid på å finne tiltak som har virket andre steder, risikerer at de er for sent ute, og at mange andre steder gjør det samme. Det er tvert imot viktig å arbeide med attraktivitet på en annerledes måte enn alle andre. 
Steder som i utgangspunktet er lite attraktive, og steder som allerede er attraktive, bør kanskje benytte seg av ulike framgangsmåter. For lite attraktive steder vil det være et framskritt å bli middels attraktive. For dem kan det dreie seg om å endre forhold som har begrenset attraktiviteten, for eksempel manglende boligbygging, manglende areal for næringsvirksomhet eller mangel på viktige ameniteter. Da vil en kopieringsstrategi kanskje virke. De fleste steder har imidlertid ambisjoner som strekker seg mot å være blant de mest attraktive. Da trenger stedet noen attraktivitetsfaktorer som skiller stedet fra andre på en mer kraftfull og synlig måte. Det er naturligvis vanskelig, men det finnes eksempler på originale tiltak.

På Rjukan satte de opp et solspeil på fjellet, som dirigerte sollys ned til torget i byen på vinteren. Rjukan er omkranset av bratte fjell som stenger sollyset ute på vinterstid. Solspeilet fikk stor oppmerksomhet i pressen, og det rapporteres om økt trafikk av turister som kommer på vinterstid for å oppleve lyset fra speilet. Seljord bygget et utkikkstårn for sjøormer. Seljordsvannet er kjent for sin sjøorm, selv om dens eksistens er omdiskutert, og har sjøormen i kommunevåpenet. Disse to tiltakene er antakelig ikke tilstrekkelige for å oppnå en signifikant bedring i besøksattraktiviteten i disse to kommunene, men er eksempler på tiltak som er ganske originale. Tiltakene er dessuten knyttet til særegne trekk på stedene og kan vanskelig kopieres. Slike tiltak kan også være med på å bedre omdømmet, ettersom de signaliserer kreativitet, lekenhet og originalitet. Det er tiltak med en X-faktor.

Steder som har ambisjoner om å bli blant de mest attraktive, må derfor sørge for å skape endringer gjennom ulike tiltak som er enten annerledes enn andre steder, eller mer kraftfulle. Når strategien for å skape et attraktivt sted er lagt, må en kunne se at den enten er original eller mer kraftfull enn tilsvarende strategier fra andre steder. Hvis ikke er det egentlig ingen grunn til å anta at stedet blir blant de mest attraktive.

\subsubsection{Tillit}

Begrepet tillit er en del av det vi legger i stedlig identitet og kultur, og er en av faktorene i denne kategorien. En kan tenke seg at tillit er en kvalitet som gjør steder mer attraktive på en direkte måte, og som kan gjøre steder mer attraktive å flytte til og bo i. Tillit kan også være et pre for næringsutviklingen. Det er gjort en del forskning på tillit mellom land, og hvordan tillit er med på å øke 
verdiskapingen og lønnsomheten i næringslivet. I land med stor grad av tillit tenker man seg at transaksjoner i næringslivet kan foregå med få fordyrende og tidkrevende formaliteter. I land med liten grad av tillit vil store ressurser gå med til å lage formelle prosedyrer, kontrakter og avtaler som sikrer både kjøper og selger fra å bli lurt. Det er langt mindre variasjon i tillit mellom regioner i et enkelt land enn det er mellom ulike land. Det kan likevel tenkes at det også er variasjon i tilliten mellom regioner i Norge, og at dette kan være en faktor som påvirker næringsattraktiviteten.

Tillit kan også være et forhold som griper inn i attraktivitetsarbeid på en annen måte. Vi har beskrevet hvordan det å skape stedlig attraktivitet krever mye arbeid over lang tid, i og med at stedet må skape forbedringer, endringer og nye kvaliteter kontinuerlig. Det er vanskelig å tenke seg at et sted kan skape sterk attraktivitet uten at en evner å mobilisere alle ressursene og aktørene. Det er ikke tilstrekkelig at kommunens politikere og administrasjon arbeider med å skape et attraktivt sted. De må også greie å få mobilisert næringslivet og frivillig sektor. Hvordan skal et sted få til en slik samlet mobilisering dersom det ikke er tillit mellom de ulike aktørene som skal arbeide mot et felles mål? Tillit er kanskje en avgjørende faktor for å få til en samlet mobilisering av ressursene på et sted.

Tillit er en egenskap som knytter seg til relasjoner mellom ulike parter. På et sted finnes det mange ulike relasjoner som tillit vil kunne variere blant.

I forbindelse med stedsutvikling er det viktig at bestemte aktører har tillit til hverandre. For å vise hvilke relasjoner dette gjelder, bruker vi det samme aktørkartet som tidligere.

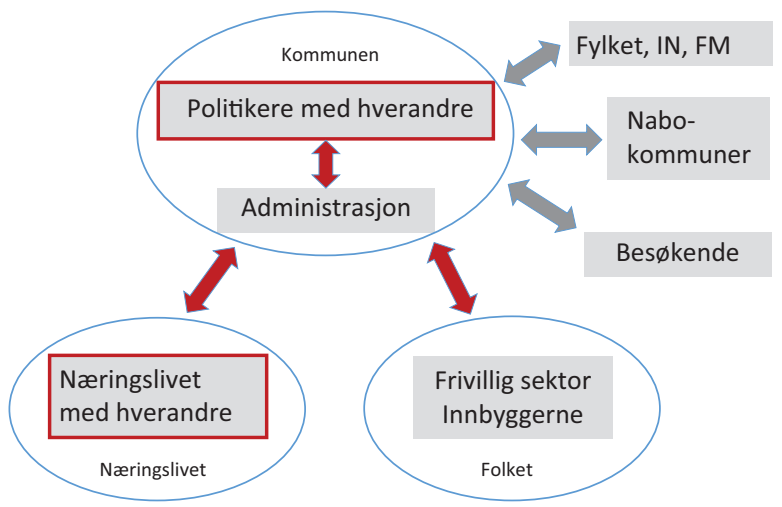

Figur 5.7 Ulike tillitsrelasjoner som er av betydning for å utvikle stedlig attraktivitet. 
Vi skal omtale de ulike relasjonene enkeltvis og forsøke å beskrive hvorfor og hvordan tillit kan være en viktig faktor.

Politikere med hverandre. Hvis vi aksepterer at det er et langsiktig og kontinuerlig arbeid å skape attraktivitet, og at kommunene er en helt sentral aktør i dette arbeidet, vil tilliten politikere imellom være en viktig faktor. Kommunestyrene blir valgt hvert fjerde år, mens det antakelig kreves langt mer enn fire år å skape vesentlige endringer i et steds attraktivitet. Det betyr at en kommune helst må ha et stabilt flertall i kommunestyret for å kunne ha en langsiktig strategi for å skape attraktivitet. En langsiktig strategi for å skape attraktivitet må derfor kunne overleve utskifting av store deler av kommunestyret, nye flertallskoalisjoner og ordførerskifter. Når Drammen kommune presenterer resultatene av sin imponerende byfornyelse, trekkes det ofte fram at dette var basert på en tverrpolitisk enighet som overlevde skiftende kommunestyrer og ordførere. Hvis tilliten mellom politikerne og de ulike politiske partiene helt mangler, er det lett å tenke seg at utviklingsstrategier kan bli kortsiktige. Kommunestyrer preget av krangel og grunnleggende mistillit og uenigheter er neppe produktive for å skape varig attraktivitet.

Politikere og administrasjon. Politikerne trenger en lojal og dyktig administrasjon for å kunne gjennomføre sine strategier. De trenger kanskje en dyktig administrasjon også for å utforme gode strategier. Det betyr at det er viktig med et tillitsfullt forhold mellom politikere og administrasjon. Det er ikke alltid tilfellet. Vi har selv besøkt en kommune for å diskutere kommunens strategier og mål, der vi fikk høre av administrasjonen at kommunens målsettinger om vekst «bare var noe surr som formannskapet hadde vedtatt». Mål og visjoner som vedtas av politikerne i en kommune, blir altså ikke alltid tatt helt alvorlig av kommunens byråkrater. Da vil administrasjonen neppe arbeide helhjertet med å realisere målene. Politikerne har heller ikke alltid høy tillit til administrasjonens kompetanse og lojalitet. Det er heller ikke fruktbart. Tillit politikere imellom og mellom politikere og administrasjon er dermed viktige faktorer for at en kommune skal kunne arbeide målrettet for å bli et attraktivt sted på lang sikt.

Noringslivet med hverandre. Bedriftene på et sted kan ha ulik grad av tillit til hverandre. Graden av tillit påvirker graden av samarbeid. Steder hvor bedriftene har stor grad av tillit til hverandre og samarbeider godt, vil kunne få en bedre næringsutvikling. Det vil også kunne bli større lokale ringvirkninger når en eller flere bedrifter utvider og investerer. Samarbeid mellom bedrifter kan 
ha mange former. Det kan dreie seg om kjøp og salg av varer og tjenester, og samarbeid om lokaler, investeringer, markedsføring og innovasjon. At bedriftene har tillit til hverandre, gjør det også lettere for dem å organisere seg $\mathrm{i}$ næringsforeninger og liknende. Det vil igjen gjøre at næringslivet vil kunne få en sterkere innflytelse på lokal næringspolitikk, som igjen vil kunne bedre betingelsene for å drive næring på stedet.

Kommune og naringsliv. Tillitsforholdet mellom kommunen og næringslivet er den kanskje viktigste relasjonen når vi snakker om tillit på stedsnivå. Det er vanskelig å se for seg en kommune som har en vellykket næringsstrategi, dersom det mangler tillit mellom næringsliv og kommune. Tillit mellom næringsliv og kommune er antakelig nødvendig for at næringslivet skal la seg påvirke av kommunens mål og strategier. Et slikt tillitsforhold er antakelig også viktig for at det skal være en åpen og god kommunikasjon mellom kommune og næringsliv i utformingen av vekststrategier. Men faktum er at det i mangetilfellermanglertillitmellom næringslivogkommune. Telemarksforsking har gjennomført ulike intervjuundersøkelser som samlet sett viser at næringslivet ofte har liten tillit til kommunen. Næringslivet har ofte bare kontakt med kommunen gjennom (for dem) omstendelige byggesaker eller gjennom å få regninger på skatt og avgifter. Det er god grunn til å tro at tillitsforholdet mellom kommune og næringslivet skranter mange steder.

Kommunen, folket og frivillig sektor. Frivillig sektor er kanskje viktigst for bostedsattraktivitet og besøksattraktivitet, og muligens mindre viktig for bedriftsattraktivitet (dersom vi holder næringsforeninger, handelsforeninger etc. utenom). Det legges ned betydelige ressurser over det ganske land i aktiviteter som styrker stedenes attraktivitet som bosted og besøkssted. Store deler av kultur- og idrettslivet er drevet av frivillig sektor. Et godt tillitsforhold mellom kommunen og frivillig sektor kan derfor være produktivt for å skape attraktivitet. Når vi snakker om tillit mellom kommunen og «folket», er det vanskeligere, ettersom det ikke finnes mange kanaler og kontaktpunkter mellom kommunen og den enkelte innbygger. Folkemøter og høringer når sjelden en stor andel av innbyggerne. Noen kommuner har forsøkt en modell kalt «gjestebud» for å få folket direkte i tale. Gjestebud er en ordning der frivillige grupper av innbyggere blir invitert til å møtes internt for å gi innspill til ønsket samfunnsutvikling. Steder som Svelvik og Rendalen har gjennomført slike gjestebud med gode erfaringer. Et beslektet problem kan være at det er problemer med tillit mellom befolkningen i ulike deler av en kommune. Det er gjerne 
slike motsetninger som kan forplante seg til kommunestyret, der utforming av strategier ender opp i tautrekking mellom ulike deler av kommunen, der alle kjemper for sin bygd eller bydel.

Kommunen, besøkende, nabokommuner og andre institusjoner. I figuren over aktører ovenfor har vi i tillegg trukket fram tillitsforhold mellom kommunen og besøkende, mellom kommunen og nabokommuner og mellom kommunen og viktige eksterne institusjoner som fylkeskommunen, Innovasjon Norge og fylkesmannen. De besøkende er sjelden en synlig aktør, men for steder med en stor fritidsbebyggelse (mange hytter) kan det være ressurser i hyttebefolkningen som kan være verdifulle. Det gjelder da å etablere kontakt med, interesse hos og tillit overfor denne gruppen. Det er det noen få kommuner som har forsøkt. Tillit og samarbeid med nabokommuner utgjør også et potensial for utvikling. Siden de fleste kommuner inngår i regionalt interkommunalt samarbeid av ulik art, er dette et viktig element.

Kan tillit skapes? Det er det all grunn til å anta. En forutsetning for tillit er at det er kommunikasjon mellom partene som skal ha tillit, og kommunikasjon kan i høyeste grad skapes. Dernest gjelder det å skape visjoner, mål og strategier for å skape attraktive steder som alle aktørene er noenlunde enige i. Det er all grunn til å tro at politikere, administrasjon, næringsliv, frivillig sektor og innbyggerne på et sted har en sterk felles interesse i at stedet er attraktivt. Vi har vært deltakere i mange strategiprosesser. Ofte ender disse opp i en anstrengende prosess hvor målet er å komme opp med konkrete tiltak med klare ansvarsforhold. Kanskje stedene i større grad burde definere hvordan de aktivt og systematisk skulle bygge opp et godt tillitsforhold mellom alle parter? 


\section{KAPITTEL 6}

\section{Veien videre}

Attraktivitetsmodellen er et forsøk på å svare på følgende to spørsmål: Hvorfor vokser noen steder mer enn andre, og hvordan kan et sted påvirke egen vekst? Et fundamentalt grep i modellen er å skille mellom strukturelle forhold (som stedene vanskelig kan påvirke) og det som stedene kan påvirke (attraktivitet). De strukturelle trekkene forklarer til dels hvorfor noen steder vokser mer enn andre på generelt grunnlag. Vekst som avviker fra forventet vekst ut fra de strukturelle forholdene, skyldes da spesielle forhold og egenskaper ved stedet. Etter vår mening er denne prinsipielle tilnærmingen nyttig både rent teoretisk for å forstå utviklingen og nyttig for dem som arbeider konkret med regional utvikling.

Attraktivitetsmodellen slik vi har presentert den i denne boka, kommer ikke til å være den endelige versjonen av attraktivitetsmodellen. Vi er sikre på at modellen blir videreutviklet og forbedret de neste årene. Det er noen overordnede prinsipper i denne modellen som vi tror blir beholdt i framtidige modeller. For det første må en modell som skal forklare steders vekst, ta høyde for både at arbeidsplassvekst påvirker flytting og befolkningsvekst, og at befolkningsveksten påvirker arbeidsplassvekst. Begge disse mekanismene er høyst reelle, og analyser som bare baserer seg på det ene årsaksforholdet, vil øve for mye vold på virkeligheten. For det andre må en modell som skal forklare arbeidsplassvekst på et sted, ta opp i seg betydningen av bransjesammensetningen på stedet. For det tredje må variabler som bakes inn i modellen, ha en signifikant forklaringskraft for historiske data. Det er ikke nok at det finnes teori eller forskningsresultater fra andre land som viser variablenes betydning. Det bør være et krav at variablene har en klar betydning for utviklingen på norske steder.

Disse tre overordnede prinsippene vil bli videreført i våre framtidige versjoner av modellen. Samtidig kan vi være nesten sikre på at det er mulig å lage en enda bedre modell. Det er nærmest uendelig mange måter å konstruere og 
spesifisere en slik modell på selv om antall variable så langt er få. Så langt har vi bare forsøkt og testet et lite antall mulige modellmuligheter.

Selv om vi lager en best tenkelig modell av denne typen, vil en slik modell ikke svare direkte på hvordan et sted kan påvirke egen utvikling. En perfekt modell av denne typen viser bare hva som er forventet utvikling på et sted ut fra de strukturelle forholdene. Det spørsmålet som alle som arbeider med regional utvikling, stiller seg, er hvordan de kan påvirke veksten på stedet. Vi tror ikke dette spørsmålet kan besvares av statistiske modeller av denne typen. Modellen svarer på om et sted har påvirket veksten positivt, men ikke hvordan. Framtidige attraktivitetsmodeller bør kunne gi mer detaljerte beskrivelser av vekstprosessene på attraktive steder. For steder med høy attraktivitet som bosted, vil det være verdifullt å kunne vite mer om hvem de har vært attraktive for. Har det vært for folk fra andre steder i regionen eller for folk langveisfra? Har det vært for personer i spesielle aldersgrupper eller utdanning? For steder som har vært attraktive for næringsliv, vil det være interessant og nyttig å vite mer om hva slags type næringsliv som har skapt veksten, og hvorvidt veksten har vært konsentrert til få eller mange bedrifter. Mens denne boka skrives, arbeider vi med nye versjoner av attraktivitetsmodellen som kan svare på dette.

For å finne ut av hvordan steder kan påvirke egen vekst, må vi gå dypere inn $\mathrm{i}$ faktiske caser med mer kvalitative studier. Som vi viste i det siste kapitlet i denne boka, finnes det ingen generell oppskrift på å skape attraktivitet på et sted. Hva som skaper attraktivitet, endrer seg over tid, kan være forskjellig fra sted til sted og er alltid avhengig av hva andre steder til enhver tid gjør. I dag er det mange steder i Norge, både små kommuner og større byer, som arbeider aktivt og systematisk for å bedre sin attraktivitet. Noen av disse vil lykkes. Erfaringer fra slike steder vil kunne gi flere nøkler til å forstå hvordan steder kan skape vekst.

\section{Ordliste og forklaring}

\begin{tabular}{ll}
\hline Begrep: & Forklaring \\
\hline Bostedsattraktivitet & Faktisk nettoflytting fratrukket forventet nettoflytting \\
\hline Næringsattraktivitet & $\begin{array}{l}\text { Faktisk vekst i antall arbeidsplasser i næringslivet fratrukket } \\
\text { forventet vekst i næringslivet }\end{array}$ \\
\hline Forventet nettoflytting & $\begin{array}{l}\text { Arbeidsplasseffekt + naboveksteffekt + størrelseseffekt + effekt av } \\
\text { arbeidsmarkedsintegrasjon }\end{array}$ \\
\hline
\end{tabular}

(Fortsatt) 


\begin{tabular}{ll}
\hline Begrep: & Forklaring \\
\hline Forventet arbeidsplassvekst & Bransjeeffekt + befolkningseffekt \\
\hline Arbeidsmarkedsintegrasjon, ekstern & Utpendling/sysselsetting + innpendling/arbeidsplasser \\
\hline Arbeidsmarkedsintegrasjon, intern & $\begin{array}{l}\text { Gjennomsnitt av verdier til kommunene av: utpendling til resten } \\
\text { av regionen/sysselsetting + innpendling fra resten av regionen/ } \\
\text { arbeidsplasser }\end{array}$ \\
\hline Nabovekst & $\begin{array}{l}\text { Relativ arbeidsplassvekst i kommuner det pendles til, vektet med } \\
\text { andelen som pendler til kommunene }\end{array}$ \\
\hline Relativ nettoflytting & Nettoflyttingen fratrukket landets nettoflytting \\
\hline Relativ arbeidsplassvekst & Arbeidsplassvekst fratrukket arbeidsplassveksten i landet \\
\hline Bransjeeffekt & $\begin{array}{l}\text { Avvik fra landets gjennomsnittlige arbeidsplassvekst og beregnet } \\
\text { arbeidsplassvekst dersom alle bransjer vokser som } \\
\text { landsgjennomsnittet }\end{array}$ \\
\hline Befolkningseffekt & $\begin{array}{l}\text { Endring i forventet arbeidsplassvekst som følge av at } \\
\text { befolkningsutviklingen avviker fra landsgjennomsnittet }\end{array}$ \\
\hline Strukturelle flyttefaktorer & $\begin{array}{l}\text { Summen av arbeidsplasseffekt, naboveksteffekt, størrelseseffekt } \\
\text { og effekt av arbeidsmarkedsintegrasjon. Samme som forventet } \\
\text { nettoflytting. }\end{array}$ \\
\hline Strukturelle arbeidsplassfaktorer & $\begin{array}{l}\text { Summen av bransjeeffekt og befolkningseffekt. Samme som } \\
\text { forventet arbeidsplassvekst i næringslivet. }\end{array}$ \\
\hline
\end{tabular}

\section{Referanser}

\begin{tabular}{|c|c|c|c|}
\hline Creamer, D. & 1942 & Shifts of manufacturing industries & $\begin{array}{l}\text { Industrial locations and } \\
\text { natural resources }\end{array}$ \\
\hline Espon & 2013 & $\begin{array}{l}\text { The attractiveness of European regions and } \\
\text { cities for residents and visitors }\end{array}$ & $\begin{array}{l}\text { ESPON \& University } \\
\text { Rovira i Virgili }\end{array}$ \\
\hline $\begin{array}{l}\text { Etzkowitz, H. \& } \\
\text { Leydesdorf, L. }\end{array}$ & 1995 & $\begin{array}{l}\text { The Triple Helix: University - Industry - } \\
\text { Government Relations: A Laboratory for } \\
\text { Knowledge-Based Economic Development }\end{array}$ & Minerva 31 \\
\hline Florida, R. & 2002 & The rise of the creative class & $\begin{array}{l}\text { New York: Perseus } \\
\text { Book Group }\end{array}$ \\
\hline Glaeser, E.L. & 2004 & $\begin{array}{l}\text { Review of Richard Florida's The Rise of the } \\
\text { Creative Class }\end{array}$ & $\begin{array}{l}\text { Regional Science and } \\
\text { Urban Economics }\end{array}$ \\
\hline Krugman, P. & 1991 & Geography and Trade & MIT Press \\
\hline
\end{tabular}

(Fortsatt) 
KAPITTEL 6

\begin{tabular}{lcll}
\hline $\begin{array}{l}\text { Niedomysl, T. \& } \\
\text { Clark, W.A.V. }\end{array}$ & 2014 & $\begin{array}{l}\text { What matters for internal migration, jobs or } \\
\text { amenities? }\end{array}$ & Migration letters \\
\hline Regjeringen SE & 2015 & $\begin{array}{l}\text { Nationell strategi for tillväxt och attraktivitet } \\
\text { 2014-2020 }\end{array}$ & Regeringskansliet \\
\hline Regjeringen SE & 2007 & Flyttning och pendling i Sverige & SOU 2007:35 \\
\hline Tillväxtanalys & 2014 & $\begin{array}{l}\text { Varför är vissa platser mer attraktiva för } \\
\text { boende än andra? }\end{array}$ & PM 2014:13 \\
\hline Ullman, E.L. & 1954 & Amenities as a Factor in Regional Growth & Geographical Review \\
\hline Vareide, K. & 2013 & Programteori for attraktivitet & Telemarksforsking \\
\hline Vareide, K. & 2014 & $\begin{array}{l}\text { Hva betyr en fast forbindelse over } \\
\text { Oslofjorden? }\end{array}$ & Telemarksforsking \\
\hline $\begin{array}{l}\text { Vareide, K. \& } \\
\text { Nygaard, M.O. }\end{array}$ & 2015 & Hva betyr det for et sted å ha en høgskole? & Telemarksforsking \\
\hline $\begin{array}{l}\text { Vareide, K. \& } \\
\text { Kobro, L.U. }\end{array}$ & 2012 & Skaper kultur attraktive steder? & 2012 \\
\hline
\end{tabular}

